\title{
Transition-Metal-Free Borylation of Alkyl lodides via a Radical
}

\section{Mechanism}

Qianyi Liu, Junting Hong, Beiqi Sun, Guangcan Bai, Feng Li, Guoquan Liu, Yang Yang, and Fanyang Mo*

\section{Contents}

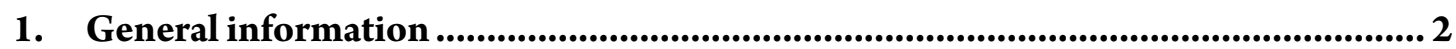

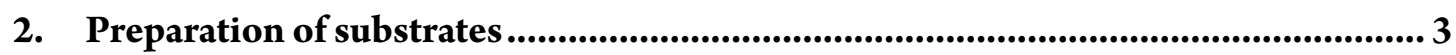

2.1 Preparation of alkyl iodides from alcohol $(1 \mathrm{f}, 1 \mathrm{k}, 1 \mathrm{~m}, 1 \mathrm{o})$.............................................. 3

2.2 Preparation of alkyl iodides from other halides $(1 \mathrm{~h}, 1 \mathrm{l}, 1 \mathrm{n}, 1 \mathrm{q}, 1 \mathrm{w}, 1 \mathrm{aa})$....................... 4

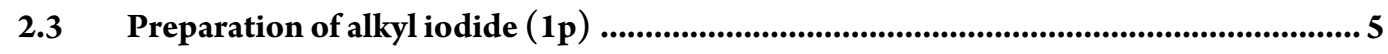

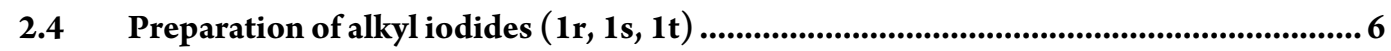

$2.5 \quad$ Preparation of alkyl iodide $(1 \mathrm{z})$..................................................................................... 7

3. Optimization of reaction conditions .............................................................................. 8

3.1 Optimization of reaction conditions for primary alkyl halides.......................................... 8

3.2 Optimization of reaction conditions for secondary alkyl halides ................................... 10

4. Experimental procedures and characterization data ................................................ 13

4.1 Procedure for borylation of primary alkyl halides ............................................................. 13

4.2 Procedure for borylation of secondary alkyl halides...................................................... 19

$4.3 \quad$ Large scale reaction ........................................................................................................... 20

4.4 GC-MS data for products measured by GC-FID or NMR ..........................................21

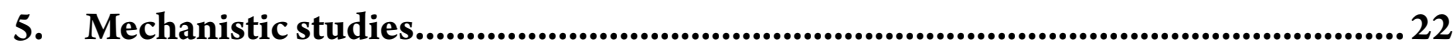

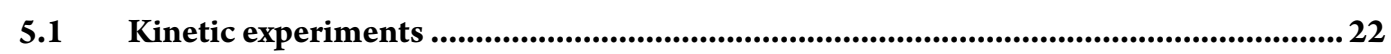

5.2 Metal residue experiments and reaction in the absence of light.......................................26

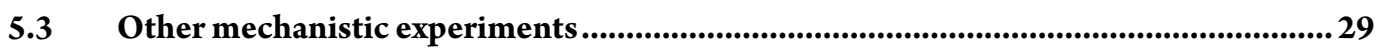

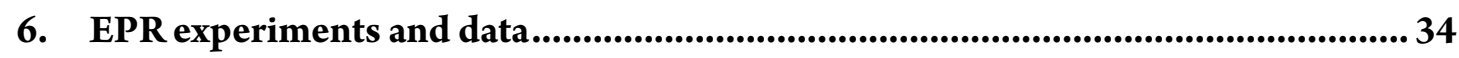

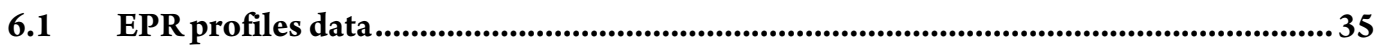

6.2 Simulations.......................................................................................................................... 44

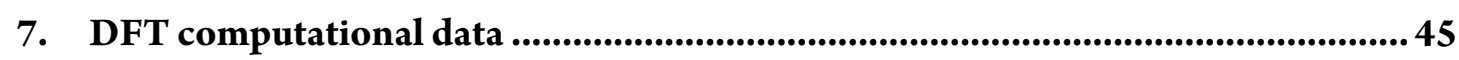

7.1 Table of energies and lowest frequencies ............................................................................. 46

7.2 Cartesian coordinates of the structures ....................................................................49

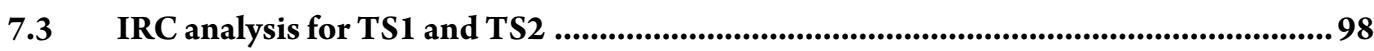

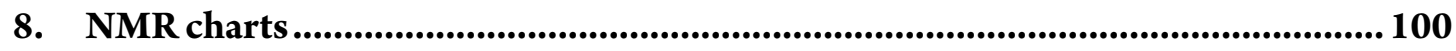

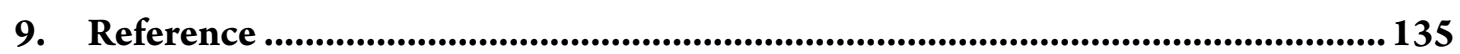




\section{General information}

Solvents were purchased from TONGGUANG CHEMICAL, Beijing or BEIJING CHEMICAL, in GR (or CCER). If not clarified, chemicals are purchased from ENERGY CHEMICAL. Purification of products was conducted by column chromatography on silica gel (200-300 mesh, for some cases 300-400 mesh were used, from Qingdao, China). NMR spectra were measured on a Bruker ARX400 $\left({ }^{1} \mathrm{H}\right.$ at $400 \mathrm{MHz},{ }^{13} \mathrm{C}$ at $\left.101 \mathrm{MHz}\right)$ magnetic resonance spectrometer. Chemical shifts $(\delta)$ are reported in ppm using tetramethylsilane as internal standard $(\mathrm{s}=$ singlet, $\mathrm{d}=$ doublet, $\mathrm{t}=$ triplet, $\mathrm{q}=$ quartet, $\mathrm{dd}=$ doublet of doublets, $\mathrm{m}=$ multiplet $)$, and coupling constants $(J)$ were reported in Hertz $(\mathrm{Hz})$. GC-MS or FID data were measured using the Agilent Technologies 7890B GC and the Agilent Technologies 5977B MSD. The FID yields were all based on standard curves with 5 points and minimum $0.996 \mathrm{R}^{2}$ value (or 4 points and minimum $0.997 \mathrm{R}^{2}$ value). EPR experiments were conducted using Bruker Elexsys E580 Spectrometer. The substrates were purchased from commercial sources unless otherwise noted. 


\section{Preparation of substrates}

\subsection{Preparation of alkyl iodides from alcohol (1f, $1 \mathrm{k}, 1 \mathrm{~m}, 1 \mathrm{o})$}

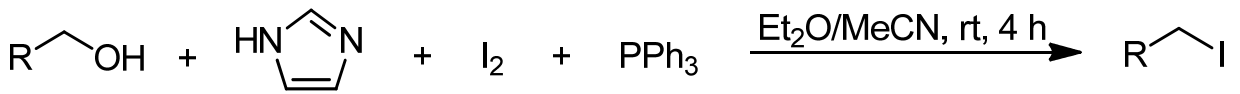

S-1 1.25 equiv. 1.3 equiv. 1.3 equiv. 1

The alkyl iodides 1 were prepared according to literature procedure ${ }^{1}$. A $100 \mathrm{~mL}$ round-bottom flask was charged with alcohol $(\mathbf{S}-1,10 \mathrm{mmol})$, imidazole $(12.5 \mathrm{mmol}, 1.25$ equiv., $851 \mathrm{mg}$ ), $\mathrm{I}_{2}(13 \mathrm{mmol}, 1.30$ equiv., $3.30 \mathrm{~g}), \mathrm{PPh}_{3}(13 \mathrm{mmol}, 1.30$ equiv., $3.41 \mathrm{~g})$, and $\mathrm{Et}_{2} \mathrm{O} / \mathrm{MeCN}(5: 1,60 \mathrm{~mL})$. The resulting solution was stirred for $4 \mathrm{~h}$ at room temperature. The reaction mixture was then quenched by $100 \mathrm{~mL}$ of sodium bicarbonate (sat.) and extracted with $3 \times 100 \mathrm{~mL}$ of ethyl acetate. The combined organic phases was dried over $\mathrm{Na}_{2} \mathrm{SO}_{4}$ and concentrated under vacuum. The residue was purified by column chromatography (silica gel) using petroleum ether (PE) as eluent to give the desired alkyl iodide $\mathbf{1}$.

(2-iodoethyl)cyclohexane (1f) 2.19 g, 92\% yield. Colorless liquid. ${ }^{1} \mathrm{H}$ NMR (400 MHz, $\left.\mathrm{CDCl}_{3}\right) \delta 3.21(\mathrm{t}, J=7.5 \mathrm{~Hz}, 2 \mathrm{H}), 1.97-1.57(\mathrm{~m}, 7 \mathrm{H}), 1.48-1.32(\mathrm{~m}, 1 \mathrm{H}), 1.32-1.08(\mathrm{~m}$, $3 \mathrm{H}), 0.99-0.80(\mathrm{~m}, 2 \mathrm{H}){ }^{2}$

1-bromo-4-(2-iodoethyl)benzene (1k) $3.21 \mathrm{~g}$, 99\% yield. Colorless liquid. ${ }^{1} \mathrm{H}$ NMR (400 $\left.\mathrm{MHz}, \mathrm{CDCl}_{3}\right) \delta 7.41(\mathrm{~d}, J=8.3 \mathrm{~Hz}, 2 \mathrm{H}), 7.07(\mathrm{~d}, J=8.3 \mathrm{~Hz}, 2 \mathrm{H}), 3.15(\mathrm{t}, J=6.8 \mathrm{~Hz}, 2 \mathrm{H})$, $2.69(\mathrm{t}, J=7.3 \mathrm{~Hz}, 2 \mathrm{H}), 2.09(\mathrm{p}, J=6.9 \mathrm{~Hz}, 2 \mathrm{H}) .^{3}$

4-hydroxy-phenethyl iodide (1 m) $2.25 \mathrm{~g}$, 91\% yield (40 mL DCM was used as solvent). White solid. ${ }^{1} \mathrm{H}$ NMR $\left(400 \mathrm{MHz}, \mathrm{CDCl}_{3}\right) \delta 7.06(\mathrm{~d}, J=8.4 \mathrm{~Hz}, 2 \mathrm{H}), 6.78(\mathrm{~d}, J=8.5 \mathrm{~Hz}$, $2 \mathrm{H}), 4.79(\mathrm{~s}, 1 \mathrm{H}), 3.30(\mathrm{t}, J=7.8 \mathrm{~Hz}, 2 \mathrm{H}), 3.10(\mathrm{t}, J=7.8 \mathrm{~Hz}, 2 \mathrm{H}){ }^{3}$

1-iodo-2-(4-methoxyphenyl)ethane (1o) 1.42 g, 54\% yield. Colorless liquid. ${ }^{1} \mathrm{H}$ NMR $\left(400 \mathrm{MHz}, \mathrm{CDCl}_{3}\right) \delta 7.10(\mathrm{~d}, J=8.6 \mathrm{~Hz}, 2 \mathrm{H}), 6.85(\mathrm{~d}, J=8.6 \mathrm{~Hz}, 2 \mathrm{H}), 3.79(\mathrm{~s}, 3 \mathrm{H}), 3.30(\mathrm{t}$, $J=7.8 \mathrm{~Hz}, 2 \mathrm{H}), 3.11(\mathrm{t}, J=7.8 \mathrm{~Hz}, 2 \mathrm{H}){ }^{4}$ 
3-iodooctane (1x) 3.14 g, 65\% yield (from $20 \mathrm{mmol}$ alcohol). Colorless liquid. ${ }^{1} \mathrm{H}$ NMR $\left(400 \mathrm{MHz}, \mathrm{CDCl}_{3}\right) \delta 4.10(\mathrm{tt}, J=8.7,4.7 \mathrm{~Hz}, 1 \mathrm{H}), 1.94-1.61(\mathrm{~m}, 4 \mathrm{H}), 1.58-1.22(\mathrm{~m}, 6 \mathrm{H})$, $1.02(\mathrm{t}, J=7.2 \mathrm{~Hz}, 3 \mathrm{H}), 0.90(\mathrm{t}, J=7.0 \mathrm{~Hz}, 3 \mathrm{H}) .^{5}$

(3-iodobutyl)benzene (1y) 2.07 g, 79\% yield. Pale-yellow liquid. ${ }^{1} \mathrm{H}$ NMR (400 MHz, $\left.\mathrm{CDCl}_{3}\right) \delta 7.35-7.26(\mathrm{~m}, 2 \mathrm{H}), 7.25-7.17(\mathrm{~m}, 3 \mathrm{H}), 4.22-3.98(\mathrm{~m}, 1 \mathrm{H}), 2.91-2.79(\mathrm{~m}$, $1 \mathrm{H}), 2.76-2.61(\mathrm{~m}, 1 \mathrm{H}), 2.35-2.07(\mathrm{~m}, 1 \mathrm{H}), 1.95(\mathrm{~d}, J=6.8 \mathrm{~Hz}, 3 \mathrm{H}), 1.93-1.83(\mathrm{~m}$, $1 \mathrm{H}){ }^{6}$

\subsection{Preparation of alkyl iodides from other halides (1h, 11, 1n, 1q, 1w, 1aa)}

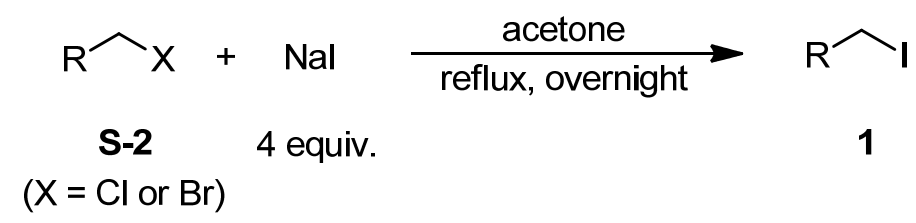

The alkyl iodides 1 were prepared according to literature procedure ${ }^{7}$. In a $100 \mathrm{~mL}$ round-bottom flask, alkyl-X $(\mathrm{X}=\mathrm{Cl}, \mathrm{Br})(\mathbf{S}-2,10 \mathrm{mmol})$ and $\mathrm{NaI}(40 \mathrm{mmol}, 4$ equiv., $6 \mathrm{~g})$ were dissolved in acetone $(30 \mathrm{~mL})$. The resulting solution was stirred overnight at reflux temperature. After cooling to room temperature, $\mathrm{CH}_{2} \mathrm{Cl}_{2}$ was added until the complete precipitation of salts. The mixture was filtered and the solvent was evaporated under vacuum. Then, the mixture was extracted with EtOAc and $0.1 \mathrm{M}$ aqueous $\mathrm{Na}_{2} \mathrm{~S}_{2} \mathrm{O}_{3}$ solution. The combined organic phases were washed with saturated brine and dried over anhydrous $\mathrm{Na}_{2} \mathrm{SO}_{4}$, then filtered and concentrated by rotary evaporation. If necessary, the crude product was purified by column chromatography on a silica gel (PE/EtOAc) to obtain the desired alkyl iodide $\mathbf{1}$.

(3-iodopropyl)benzene (1h) $2.11 \mathrm{~g}$, 86\% yield (from chloride). Orange liquid. ${ }^{1} \mathrm{H}$ NMR $\left(400 \mathrm{MHz}, \mathrm{CDCl}_{3}\right) \delta 7.40-7.23(\mathrm{~m}, 2 \mathrm{H}), 7.23-7.02(\mathrm{~m}, 3 \mathrm{H}), 3.15(\mathrm{t}, J=6.8 \mathrm{~Hz}, 2 \mathrm{H})$, $2.71(\mathrm{t}, J=7.3 \mathrm{~Hz}, 2 \mathrm{H}), 2.11(\mathrm{p}, J=7.0 \mathrm{~Hz}, 2 \mathrm{H}){ }^{8}$ 
1-iodohexan-6-ol (11) $2.26 \mathrm{~g}$, 99\% yield (from chloride). Colorless liquid. ${ }^{1} \mathrm{H}$ NMR (400 $\left.\mathrm{MHz} \mathrm{CDCl}_{3}\right) \delta 3.77-3.48(\mathrm{~m}, 2 \mathrm{H}), 3.20(\mathrm{t}, J=7.0 \mathrm{~Hz}, 2 \mathrm{H}), 1.84(\mathrm{p}, J=7.0 \mathrm{~Hz}, 2 \mathrm{H}), 1.59$ $(\mathrm{p}, J=6.6 \mathrm{~Hz}, 2 \mathrm{H}), 1.48-1.22(\mathrm{~m}, 5 \mathrm{H}) .^{9}$

4-iodobutyl methyl ether (1n) 2.11 g, 99\% yield (from chloride). Orange liquid. ${ }^{1} \mathrm{H}$ NMR $\left(400 \mathrm{MHz}, \mathrm{CDCl}_{3}\right) \delta 3.39(\mathrm{t}, J=6.2 \mathrm{~Hz}, 2 \mathrm{H}), 3.32(\mathrm{~s}, 3 \mathrm{H}), 3.22(\mathrm{t}, J=7.0 \mathrm{~Hz}, 2 \mathrm{H}), 1.97-$ $1.85(\mathrm{~m}, 2 \mathrm{H}), 1.73-1.61(\mathrm{~m}, 2 \mathrm{H}) .^{10}$

1-(3-iodopropoxy)benzene (1q) $2.57 \mathrm{~g}$, $98 \%$ yield (from bromide). Colorless liquid. ${ }^{1} \mathrm{H}$ $\operatorname{NMR}\left(400 \mathrm{MHz}, \mathrm{CDCl}_{3}\right) \delta 7.37-7.26(\mathrm{~m}, 2 \mathrm{H}), 7.02-6.93(\mathrm{~m}, 1 \mathrm{H}), 6.93-6.79(\mathrm{~m}, 2 \mathrm{H})$, $4.04(\mathrm{t}, J=5.8 \mathrm{~Hz}, 2 \mathrm{H}), 3.38(\mathrm{t}, J=6.7 \mathrm{~Hz}, 2 \mathrm{H}), 2.38-2.14(\mathrm{~m}, 2 \mathrm{H}) .{ }^{11}$

Iodocycloheptane (1w) $1.94 \mathrm{~g}$, 87\% yield (from bromide). Pale-yellow liquid. ${ }^{1} \mathrm{H}$ NMR $\left(400 \mathrm{MHz}, \mathrm{CDCl}_{3}\right) \delta 4.49(\mathrm{tt}, \mathrm{J}=8.8,4.3 \mathrm{~Hz}, 1 \mathrm{H}), 2.38-2.23(\mathrm{~m}, 2 \mathrm{H}), 2.23-2.10(\mathrm{~m}, 2 \mathrm{H})$, $1.70-1.55(\mathrm{~m}, 6 \mathrm{H}), 1.52-1.36(\mathrm{~m}, 2 \mathrm{H}){ }^{6}$

(Iodomethyl)cyclopropane (1aa) $2.53 \mathrm{~g}$, 70\% yield (from 20 mmol bromide). Colorless liquid. Purified by extraction with $\mathrm{PE}\left(30 \sim 60^{\circ} \mathrm{C}\right)$ and evaporated under $\mathrm{P}>=0.2 \mathrm{~atm}$ and $\mathrm{T}$ $<=20^{\circ} \mathrm{C} .{ }^{1} \mathrm{H}$ NMR $\left(400 \mathrm{MHz}, \mathrm{CDCl}_{3}\right) \delta 3.14(\mathrm{dd}, \mathrm{J}=7.7,1.6 \mathrm{~Hz}, 2 \mathrm{H}), 1.41-1.22(\mathrm{~m}, 1 \mathrm{H})$, $0.90-0.74(\mathrm{~m}, 2 \mathrm{H}), 0.31(\mathrm{td}, \mathrm{J}=4.7,2.5 \mathrm{~Hz}, 2 \mathrm{H}) .{ }^{12}$

\subsection{Preparation of alkyl iodide (1p)}

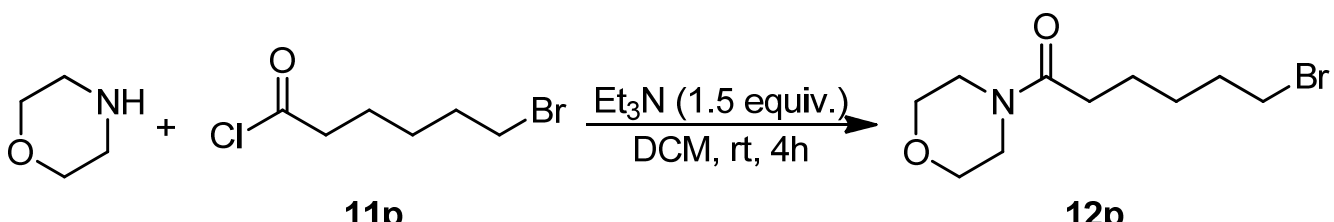

$11 p$

$12 p$

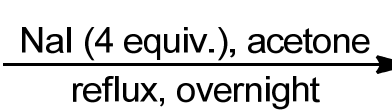<smiles>O=C(CCCCCI)N1CCOCC1</smiles>

In a well-dried flask, morpholine $(10 \mathrm{mmol}, 1$ equiv., $870 \mu \mathrm{L})$ and $\mathrm{Et}_{3} \mathrm{~N}(15 \mathrm{mmol}, 1.5$ equiv., $2.08 \mathrm{~mL})$ were dissolved in DCM $(25 \mathrm{~mL})$ and cooled in an ice bath. After a solution of $\mathbf{1 1 p}$ $(10 \mathrm{mmol}, 1.53 \mathrm{~mL})$ in DCM $(15 \mathrm{~mL})$ was added dropwise during $30 \mathrm{~min}$, the mixture was allowed to warm into room temperature and stirred for another $4 \mathrm{~h}$. The reaction mixture 
was poured into water $(100 \mathrm{~mL})$ and extracted with $\mathrm{DCM}(50 \mathrm{~mL} \times 3)$. The combined organic phase was dried over anhydrous $\mathrm{Na}_{2} \mathrm{SO}_{4}$, filtered, and concentrated by rotary evaporation. Compound 12p was purified by column chromatography (silica gel) using PE/EA 5:1 3:1 as eluent. Yield: $2.40 \mathrm{~g}$ (91\%), colorless liquid. After that, 12p (5 mmol) was dissolved in acetone $(20 \mathrm{~mL})$. NaI $(20 \mathrm{mmol}$, 4 equiv., $3 \mathrm{~g})$ was added. Compound $\mathbf{1 p}$ was then obtained according to the procedure in Section 2.2.

6-bromo-1-(morpholin-4-yl)-hexan-1-one (12p) $2.40 \mathrm{~g}$, $91 \%$ yield. Colorless liquid. ${ }^{1} \mathrm{H}$ $\mathrm{NMR}\left(400 \mathrm{MHz}, \mathrm{CDCl}_{3}\right) \delta 3.80-3.53(\mathrm{~m}, 6 \mathrm{H}), 3.53-3.26(\mathrm{~m}, 4 \mathrm{H}), 2.33(\mathrm{t}, J=7.5 \mathrm{~Hz}$, $2 \mathrm{H}), 1.98-1.79(\mathrm{~m}, 2 \mathrm{H}), 1.77-1.58(\mathrm{~m}, 2 \mathrm{H}), 1.57-1.41(\mathrm{~m}, 2 \mathrm{H}) .{ }^{13}$

6-iodo-1-(morpholin-4-yl)-hexan-1-one (1p) $1.55 \mathrm{~g}$, 99\% yield. Colorless liquid. ${ }^{1} \mathrm{H}$ $\operatorname{NMR}\left(400 \mathrm{MHz}, \mathrm{CDCl}_{3}\right) \delta 3.78-3.52(\mathrm{~m}, 6 \mathrm{H}), 3.46(\mathrm{t}, J=4.9 \mathrm{~Hz}, 2 \mathrm{H}), 3.20(\mathrm{t}, J=6.9 \mathrm{~Hz}$, $2 \mathrm{H}), 2.39-2.22(\mathrm{~m}, 2 \mathrm{H}), 1.86(\mathrm{p}, J=7.1 \mathrm{~Hz}, 2 \mathrm{H}), 1.67(\mathrm{dt}, J=15.2,7.5 \mathrm{~Hz}, 2 \mathrm{H}), 1.53-$ $1.37(\mathrm{~m}, 2 \mathrm{H})$.

\subsection{Preparation of alkyl iodides $(1 \mathrm{r}, 1 \mathrm{~s}, 1 \mathrm{t})$}<smiles>[R]c1ccc(OCCCBr)cc1</smiles>

S-3

8 equiv.

$\underset{\text { reflux, overnight }}{\stackrel{\text { Nal (4 equiv.), acetone }}{\longrightarrow}}$<smiles>[R]c1ccc(OCCCI)cc1</smiles>

1

The alkyl iodide $\mathbf{1}$ were prepared according to literature procedure ${ }^{14}$. A solution of phenol S-3 (10 mmol) and 1,3-dibromopropane ( $80 \mathrm{mmol}$, 8 equiv., $8 \mathrm{~mL})$ in $\mathrm{MeCN}(30 \mathrm{~mL})$ was adding anhydrous potassium carbonate $(40 \mathrm{mmol}$, 4 equiv., $5.5 \mathrm{~g})$. The reaction mixture was stirred at reflux for $24 \mathrm{~h}$, and then potassium carbonate was removed by suction filtration and the solvent was removed under reduced pressure. The residue was purified by column chromatography (silica gel) using PE/EtOAc as eluent to obtain compound S-4. After that, the product $1 \mathbf{r} / \mathbf{1 s} / \mathbf{1 t}$ was prepared according to the procedure in Section 2.2. 
methyl 4-(3-iodo-propoxy)-benzoate (1r) $1.68 \mathrm{~g}$, 52\% yield. Pale-yellow liquid. ${ }^{1} \mathrm{H}$ NMR $\left(400 \mathrm{MHz}, \mathrm{CDCl}_{3}\right) \delta 7.92(\mathrm{~d}, J=8.9 \mathrm{~Hz}, 2 \mathrm{H}), 6.85(\mathrm{~d}, J=8.9 \mathrm{~Hz}, 2 \mathrm{H}), 4.02(\mathrm{t}, J=5.8 \mathrm{~Hz}$, $2 \mathrm{H}), 3.81(\mathrm{~s}, 3 \mathrm{H}), 3.30(\mathrm{t}, J=6.7 \mathrm{~Hz}, 2 \mathrm{H}), 2.22(\mathrm{p}, J=6.5 \mathrm{~Hz}, 2 \mathrm{H}) .{ }^{15}$

acetic acid-[4-(3-iodo-propoxy)-anilide] (1s) $1.57 \mathrm{~g}$, 77\% yield. Colorless liquid. ${ }^{1} \mathrm{H}$ $\operatorname{NMR}\left(400 \mathrm{MHz}, \mathrm{CDCl}_{3}\right) \delta 7.38(\mathrm{~d}, J=9.0 \mathrm{~Hz}, 2 \mathrm{H}), 7.19(\mathrm{~s}, 1 \mathrm{H}), 6.86(\mathrm{~d}, J=8.9 \mathrm{~Hz}, 2 \mathrm{H})$, $4.01(\mathrm{t}, J=5.8 \mathrm{~Hz}, 2 \mathrm{H}), 3.36(\mathrm{t}, J=6.7 \mathrm{~Hz}, 2 \mathrm{H}), 2.26(\mathrm{p}, J=6.3 \mathrm{~Hz}, 2 \mathrm{H}), 2.15(\mathrm{~s}, 3 \mathrm{H})$.

1-(3-iodo-propoxy)-4-(methyl-sulfonyl)-benzene (1t) $1.68 \mathrm{~g}$, 86\% yield. Colorless liquid. ${ }^{1} \mathrm{H} \mathrm{NMR}\left(400 \mathrm{MHz}, \mathrm{CDCl}_{3}\right) \delta 7.87(\mathrm{~d}, J=8.9 \mathrm{~Hz}, 2 \mathrm{H}), 7.04(\mathrm{~d}, J=8.9 \mathrm{~Hz}, 2 \mathrm{H}), 4.20(\mathrm{t}, J=$ $5.8 \mathrm{~Hz}, 2 \mathrm{H}), 3.61(\mathrm{t}, J=6.3 \mathrm{~Hz}, 2 \mathrm{H}), 3.03(\mathrm{~s}, 3 \mathrm{H}), 2.36(\mathrm{p}, J=6.1 \mathrm{~Hz}, 2 \mathrm{H})$.

\subsection{Preparation of alkyl iodide (1z)}

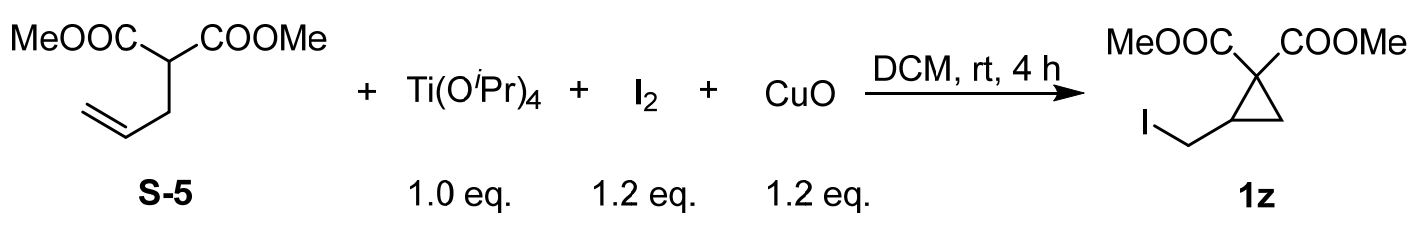

The alkyl iodide $\mathbf{1 z}$ was prepared according to literature procedure ${ }^{16}$. Under $\mathrm{N}_{2}$ atmosphere, to a solution of dimethyl allylmalonate $(10 \mathrm{mmol}, 1.72 \mathrm{~g})$ in DCM $(12 \mathrm{~mL})$ was added $\mathrm{Ti}(\mathrm{O} i-\mathrm{Pr})_{4}(10 \mathrm{mmol}, 1.0$ equiv., $3 \mathrm{~mL})$ and stirred for $10 \mathrm{~min}$. $\mathrm{I}_{2}(12 \mathrm{mmol}, 1.2$ equiv., $3.05 \mathrm{~g})$ and $\mathrm{CuO}$ ( $12 \mathrm{mmol}, 1.2$ equiv., $0.95 \mathrm{~g})$ were successively added, and then the mixture was stirred for $4 \mathrm{~h}$. The mixture was poured into $10 \% \mathrm{HCl}$, and the product was extracted with ether. The ether extracts were washed with aqueous $\mathrm{Na}_{2} \mathrm{~S}_{2} \mathrm{O}_{3}$ solution, dried over $\mathrm{Na}_{2} \mathrm{SO}_{4}$, and evaporated. The residue was crudely purified by column chromatography (PE/EA = 9:1) and the product $\mathbf{1 z}$ was purified by recrystallization using PE/EA under $-18{ }^{\circ} \mathrm{C}$.

dimethyl 2-(iodomethyl)cyclopropane-1,1-dicarboxylate (1z) 1.51 g, 51\% yield. White solid. ${ }^{1} \mathrm{H}$ NMR (400 MHz, $\mathrm{CDCl}_{3}$ ) $\delta 3.81$ (s, 3H), 3.75 (s, 3H), $3.22(\mathrm{dd}, J=10.3,7.6 \mathrm{~Hz}$, $1 \mathrm{H}), 3.13(\mathrm{dd}, J=10.3,8.4 \mathrm{~Hz}, 1 \mathrm{H}), 2.54-2.40(\mathrm{~m}, 1 \mathrm{H}), 1.62(\mathrm{dd}, J=9.0,5.1 \mathrm{~Hz}, 1 \mathrm{H})$, $1.54(\mathrm{dd}, J=7.6,5.1 \mathrm{~Hz}, 1 \mathrm{H}) .{ }^{13} \mathrm{C} \mathrm{NMR}\left(101 \mathrm{MHz}, \mathrm{CDCl}_{3}\right) \delta 167.47,165.80,51.05,51.02$, $36.49,29.24,22.38 .^{17}$ 


\section{Optimization of reaction conditions}

\subsection{Optimization of reaction conditions for primary alkyl halides}

In a glove box, a vial equipped with a stir bar was charged with base, $B_{2} \operatorname{pin}_{2}, n$-iodooctane $\mathbf{1 a}$ (0.5 mmol, $120 \mathrm{mg}, 91 \mu \mathrm{L})$ or $n$-bromooctane 1a' $(0.5 \mathrm{mmol}, 97 \mathrm{mg}, 87 \mu \mathrm{L})$, other additives and the solvent. After removing the sealed vial from the glove box, the reaction mixture was stirred at given temperature for given time. Upon cooling to room temperature, $n$-decane $(\sim$ $30 \mathrm{mg}$ ) was added, the conversion of halide and the yield were measured by GC (FID).

Table S1 Optimization of reaction conditions for primary alkyl halides.

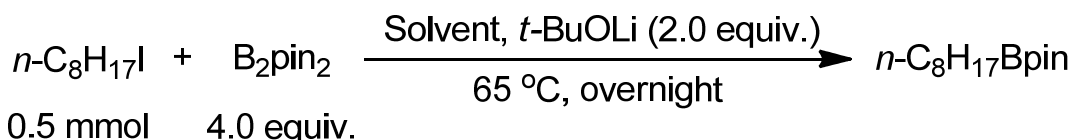

\begin{tabular}{|l|l|l|l|l|}
\hline Entry & Solvent and conditions & Conv. of $\mathrm{C}_{8} \mathrm{H}_{17} \mathrm{I}$ & Conv. of $\mathrm{B}_{2}$ pin $_{2}$ & Yield \\
\hline 1 & $\mathrm{MeOH}(2 \mathrm{~mL}), 9 \mathrm{~h}$ & $90.2 \%$ & $49.2 \%$ & $61.3 \%$ \\
\hline 2 & $\mathrm{MeOH}(1 \mathrm{~mL})$ & $95.7 \%$ & $60.0 \%$ & $69.5 \%$ \\
\hline 3 & $\mathrm{MeOH}(0.5 \mathrm{~mL})$ & $97.4 \%$ & $60.9 \%$ & $72.6 \%$ \\
\hline 4 & $\mathrm{MeCN}(1 \mathrm{~mL})$ & $99.6 \%$ & $37.2 \%$ & $64.4 \%$ \\
\hline 5 & $\mathrm{DMF}(1 \mathrm{~mL})$ & $100 \%$ & $31.1 \%$ & $55.0 \%$ \\
\hline 6 & $\mathrm{DCM}(1 \mathrm{~mL})$ & $47.4 \%$ & $29.7 \%$ & $14.9 \%$ \\
\hline 7 & $\mathrm{MeOH}(1 \mathrm{~mL}), 80^{\circ} \mathrm{C}, 6 \mathrm{~h}$ & $100 \%$ & $65.8 \%$ & $64.0 \%$ \\
\hline
\end{tabular}

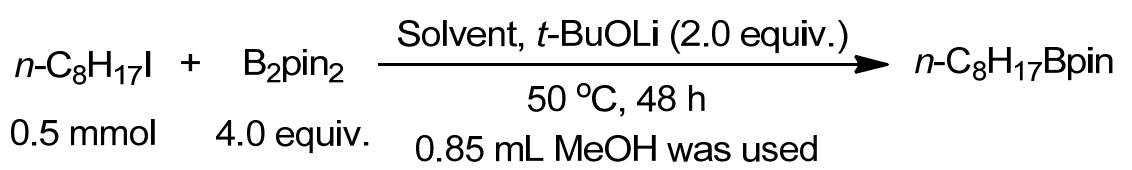

\begin{tabular}{|l|l|l|l|l|}
\hline Entry & Conditions & Conv. of $\mathrm{C}_{8} \mathrm{H}_{17} \mathrm{I}$ & Conv. of $\mathrm{B}_{2}$ pin $_{2}$ & Yield \\
\hline 8 & MeOH/DMF 20:1 & $95.6 \%$ & $60.2 \%$ & $76.0 \%$ \\
\hline 9 & $\mathrm{MeOH} /$ DMF 5:1 & $84.3 \%$ & $55.3 \%$ & $63.0 \%$ \\
\hline 10 & $\begin{array}{l}\mathrm{MeOH} / \mathrm{H}_{2} \mathrm{O} 85: 1, \\
\text { with TEMPO (2 eq. })\end{array}$ & $52.6 \%$ & $84.5 \%$ & $14.4 \%$ \\
\hline $\mathbf{1 1}$ & $\mathbf{M e O H} / \mathbf{H}_{2} \mathbf{O ~ 8 5 : 1}$ & $\mathbf{9 8 . 5 \%}$ & $\mathbf{5 8 . 3 \%}$ & $\mathbf{8 6 . 7 \%}$ \\
\hline
\end{tabular}

$$
\begin{aligned}
& n-\mathrm{C}_{8} \mathrm{H}_{17} \mathrm{I}+\mathrm{B}_{2} \mathrm{pin}_{2} \underset{\mathrm{MeOH} / \mathrm{H}_{2} \mathrm{O} 85: 1, t \text {-BuOLi }}{50^{\circ} \mathrm{C}, 48 \mathrm{~h}} \rightarrow n-\mathrm{C}_{8} \mathrm{H}_{17} \text { Bpin } \\
& 0.5 \mathrm{mmol}
\end{aligned}
$$

\begin{tabular}{|l|l|l|l|l|l|}
\hline Entry & $\mathrm{B}_{2}$ pin $_{2}$ equiv. & $t$-BuOLi equiv. & Conv. of $\mathrm{C}_{8} \mathrm{H}_{17} \mathrm{I}$ & Conv. of $\mathrm{B}_{2}$ pin $_{2}$ & Yield \\
\hline $\mathbf{1 1}$ & $\mathbf{4 . 0}$ & $\mathbf{2 . 0}$ & $\mathbf{9 8 . 5} \%$ & $\mathbf{5 8 . 3 \%}$ & $\begin{array}{l}\mathbf{8 6 . 7 \%} \\
(\mathbf{8 6 . 2 \%} \\
\end{array}$ \\
& & & & & isolated) \\
\hline 12 & 4.0 & 3.0 & $100 \%$ & $92.3 \%$ & $67.7 \%$ \\
\hline
\end{tabular}




\begin{tabular}{|l|l|l|l|l|l|}
\hline 13 & 3.5 & 2.0 & $98.1 \%$ & $69.5 \%$ & $76.3 \%$ \\
\hline 14 & 3.5 & 1.5 & $100 \%$ & $57.5 \%$ & $76.9 \%$ \\
\hline $\mathbf{1 5}$ & $\mathbf{3 . 0}$ & $\mathbf{1 . 5}$ & $\mathbf{1 0 0} \%$ & $\mathbf{6 1 . 9 \%}$ & $\begin{array}{l}\mathbf{8 3 . 8 \%} \\
(\mathbf{8 2 . 7 \%} \\
\text { isolated })\end{array}$ \\
\hline 16 & 2.5 & 1.5 & $100 \%$ & $74.9 \%$ & $71.5 \%$ \\
\hline 17 & 2.0 & 1.5 & $95.6 \%$ & $78.8 \%$ & $60.2 \%$ \\
\hline 18 & 2.0 & 1.0 & $85.7 \%$ & $77.6 \%$ & $61.9 \%$ \\
\hline
\end{tabular}

$$
n-\mathrm{C}_{8} \mathrm{H}_{17} \mathrm{I}+\mathrm{B}_{2} \mathrm{pin}_{2} \stackrel{\mathrm{MeOH} / \mathrm{H}_{2} \mathrm{O} 85: 1 \text {, base (2.0 equiv.) }}{50^{\circ} \mathrm{C}, 48 \mathrm{~h}} n-\mathrm{C}_{8} \mathrm{H}_{17} \text { Bpin }
$$

$0.5 \mathrm{mmol} \quad 4.0$ equiv.

\begin{tabular}{|l|l|l|l|l|}
\hline Entry & Base & Conv. of $\mathrm{C}_{8} \mathrm{H}_{17} \mathrm{I}$ & Conv. of $\mathrm{B}_{2} \mathrm{pin}_{2}$ & Yield \\
\hline $\mathbf{1 1}$ & $\boldsymbol{t}$-BuOLi & $\mathbf{9 8 . 5 \%}$ & $\mathbf{5 8 . 3 \%}$ & $\mathbf{8 6 . 7 \%}(\mathbf{8 6 . 2 \%}$ isolated) \\
\hline 19 & $\mathrm{MeOLi}$ & $95.0 \%$ & $66.1 \%$ & $63.7 \%$ \\
\hline 20 & $t$-BuONa & $90.3 \%$ & $90.3 \%$ & $65.9 \%$ \\
\hline 21 & $\mathrm{MeONa}$ & $88.3 \%$ & $84.6 \%$ & $61.6 \%$ \\
\hline 22 & $t$-BuOK & $84.9 \%$ & $96.8 \%$ & $49.6 \%$ \\
\hline 23 & $\mathrm{MeOK}$ & $93.1 \%$ & $94.4 \%$ & $62.5 \%$ \\
\hline 24 & $\mathrm{Cs}_{2} \mathrm{CO}_{3}$ & $100 \%$ & $97.1 \%$ & $14.8 \%$ \\
\hline 25 & $\mathrm{LiOH} \mathrm{H}_{2} \mathrm{O}$ & $96.1 \%$ & $91.9 \%$ & $66.5 \%$ \\
\hline
\end{tabular}

$$
\begin{aligned}
& n-\mathrm{C}_{8} \mathrm{H}_{17} \mathrm{Br}+\mathrm{B}_{2} \mathrm{pin}_{2} \underset{\left[\mathrm{MeOH} /, 50^{\circ} \mathrm{C}, 48 \mathrm{~h}\right.}{\stackrel{\mathrm{O}}{\mathrm{O}} 85: 1, t \text {-BuOLi (2.0 equiv.) }} \rightarrow n-\mathrm{C}_{8} \mathrm{H}_{17} \text { Bpin } \\
& 0.5 \mathrm{mmol} \quad 4.0 \text { equiv. }
\end{aligned}
$$

\begin{tabular}{|l|l|l|l|l|}
\hline Entry & {$[\mathrm{I}]$} & Conv. of $\mathrm{C}_{8} \mathrm{H}_{17} \mathrm{Br}$ & Conv. of $\mathrm{B}_{2} \operatorname{pin}_{2}$ & Yield \\
\hline 26 & None & $39.2 \%$ & $79.5 \%$ & $25.9 \%$ \\
\hline 27 & $\mathrm{KI}(0.2$ equiv. $)$ & $81.1 \%$ & $73.1 \%$ & $55.5 \%$ \\
\hline 28 & $\mathrm{I}_{2}(0.2$ equiv. $)$ & $94.9 \%$ & $72.7 \%$ & $71.8 \%$ \\
\hline 29 & $\mathrm{I}_{2}(0.1$ equiv. $)$ & $90.8 \%$ & $70.4 \%$ & $59.4 \%$ \\
\hline $\mathbf{3 0}$ & $\mathrm{I}_{2}(\mathbf{0 . 4}$ equiv. $)$ & $\mathbf{9 9 . 8 \%}$ & $\mathbf{7 0 . 5 \%}$ & $\mathbf{7 6 . 2 \%}$ \\
\hline 31 & $\mathrm{KI}(0.1$ equiv. $)$ & $80.6 \%$ & $74.8 \%$ & $51.6 \%$ \\
\hline 32 & $\mathrm{KI}(0.4$ equiv. $)$ & $97.1 \%$ & $74.5 \%$ & $70.0 \%$ \\
\hline
\end{tabular}

\begin{tabular}{|c|c|c|c|c|c|}
\hline Entry & $\mathrm{B}_{2}$ pin $_{2}$ equiv. & $t$-BuOLi equiv. & Conv. of $\mathrm{C}_{8} \mathrm{H}_{17} \mathrm{Br}$ & Conv. of $\mathrm{B}_{2} \mathrm{pin}_{2}$ & Yield \\
\hline 28 & 4.0 & 2.0 & $94.9 \%$ & $72.7 \%$ & $71.8 \%$ \\
\hline 33 & 3.0 & 1.5 & $97.1 \%$ & $86.5 \%$ & $65.9 \%$ \\
\hline 34 & 2.0 & 1.0 & $79.3 \%$ & $61.2 \%$ & $44.3 \%$ \\
\hline
\end{tabular}

$$
n-\mathrm{C}_{8} \mathrm{H}_{17} \mathrm{Br}+\mathrm{B}_{2} \mathrm{pin}_{2} \underset{\mathrm{I}_{2}(0.2 \text { equiv. }), 50^{\circ} \mathrm{C}, 48 \mathrm{~h}}{\stackrel{\mathrm{MeOH} / \mathrm{H}_{2} \mathrm{O} 85: 1, t \text {-BuOLi }}{\longrightarrow}} n-\mathrm{C}_{8} \mathrm{H}_{17} \text { Bpin }
$$

$0.5 \mathrm{mmol}$

$$
\begin{aligned}
& n-\mathrm{C}_{8} \mathrm{H}_{17} \mathrm{Br}+\mathrm{B}_{2} \mathrm{pin}_{2} \frac{\mathrm{MeOH} / \mathrm{H}_{2} \mathrm{O} 85: 1, t \text {-BuOLi (1.5 equiv.) }}{[\mathrm{l}], 50^{\circ} \mathrm{C}, 48 \mathrm{~h}} n-\mathrm{C}_{8} \mathrm{H}_{17} \text { Bpin } \\
& 0.5 \mathrm{mmol} \quad 3.0 \text { equiv. }
\end{aligned}
$$




\begin{tabular}{|l|l|l|l|l|}
\hline Entry & {$[\mathrm{I}]$} & Conv. of $\mathrm{C}_{8} \mathrm{H}_{17} \mathrm{Br}$ & Conv. of $\mathrm{B}_{2} \mathrm{pin}_{2}$ & Yield \\
\hline $\mathbf{3 3}$ & $\mathrm{I}_{\mathbf{2}}$ (0.2 eq.) & $\mathbf{9 7 . 1 \%}$ & $\mathbf{8 6 . 5 \%}$ & $\mathbf{6 5 . 9 \%}$ \\
\hline 35 & $\mathrm{I}_{2}$ (0.4 eq.) & $92.5 \%$ & $56.6 \%$ & $56.4 \%$ \\
\hline 36 & $\mathrm{I}_{2}$ (1 eq.) & $78.8 \%$ & $35.7 \%$ & Trace \\
\hline 37 & $\mathrm{KI}(0.2$ eq.) & $76.3 \%$ & $68.4 \%$ & $44.2 \%$ \\
\hline 38 & $\mathrm{KI}(0.4$ eq.) & $83.4 \%$ & $67.9 \%$ & $43.9 \%$ \\
\hline 39 & $\mathrm{KI}(1$ eq.) & $100 \%$ & $70.3 \%$ & $62.5 \%$ \\
\hline
\end{tabular}

$$
\begin{aligned}
& n-\mathrm{C}_{8} \mathrm{H}_{17} \mathrm{X}+\mathrm{B}_{2} \mathrm{pin}_{2} \frac{\left.\mathrm{MeOH} / \mathrm{H}_{2} \mathrm{O} 85: 1, t \text {-BuOLi (2.0 equiv. }\right)}{[\mathrm{l}](0.2 \text { equiv. }), 50^{\circ} \mathrm{C}, 48 \mathrm{~h}} n-\mathrm{C}_{8} \mathrm{H}_{17} \text { Bpin } \\
& 0.5 \mathrm{mmol} \quad 4.0 \text { equiv. }
\end{aligned}
$$

\begin{tabular}{|l|l|l|l|l|l|}
\hline Entry & $\mathrm{X}$ & {$[\mathrm{I}]$} & Conv. of $\mathrm{C}_{8} \mathrm{H}_{17} \mathrm{X}$ & Conv. of $\mathrm{B}_{2}$ pin $_{2}$ & Yield \\
\hline 40 & $\mathrm{Cl}$ & $\mathrm{KI}$ & $17.6 \%$ & $71.2 \%$ & $6.9 \%$ \\
\hline 41 & $\mathrm{Cl}$ & $\mathrm{I}_{2}$ & $10.3 \%$ & $57.8 \%$ & $10.4 \%$ \\
\hline 42 & OTs & None & & & $\mathrm{ND}$ \\
\hline 43 & OTs & KI & - & $65.1 \%$ & $9.2 \%$ \\
\hline 44 & OTs & $\mathrm{I}_{2}$ & - & $57.0 \%$ & $17.5 \%$ \\
\hline 45 & OMs & None & & & $\mathrm{ND}$ \\
\hline 46 & OMs & KI & - & $62.1 \%$ & $36.3 \%$ \\
\hline 47 & OMs & $\mathrm{I}_{2}$ & - & $53.2 \%$ & $45.0 \%$ \\
\hline 48 & OTf & None & & & $\mathrm{ND}$ \\
\hline 49 & OTf & KI & - & $48.3 \%$ & $9.0 \%$ \\
\hline 50 & OTf & $\mathrm{I}_{2}$ & - & $61.3 \%$ & $3.9 \%$ \\
\hline
\end{tabular}

\subsection{Optimization of reaction conditions for secondary alkyl halides}

Procedure A: using $\mathrm{B}_{2}$ pin $_{2}$ directly.

In a glove box, a vial equipped with a stir bar was charged with base, $B_{2} \operatorname{pin}_{2}$, iodocyclohexane $1 \mathbf{u}(0.5 \mathrm{mmol}, 105 \mathrm{mg}, 65 \mu \mathrm{L})$ and the solvent. After removing the sealed vial from the glove box, the reaction mixture was stirred at given temperature for given time. Upon cooling to room temperature, $n$-decane $(\sim 30 \mathrm{mg})$ was added, the conversion of halide and the yield were measured by GC (FID).

Table S2. Optimization of secondary alkyl halides: using $\mathrm{B}_{2} \mathrm{pin}_{2}$ as reagent.

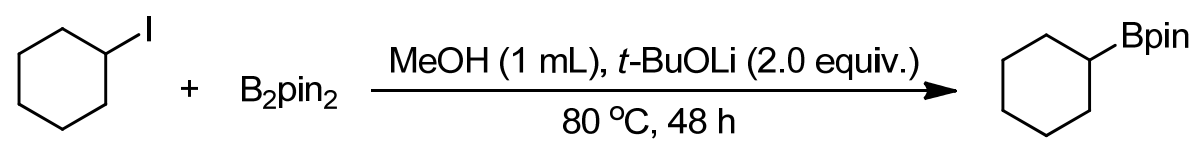

$0.5 \mathrm{mmol} \quad 4.0$ equiv.

\begin{tabular}{|l|l|l|l|l|}
\hline Entry & Conditions & Conv. of Substrate & Conv. of $\mathrm{B}_{2} \mathrm{pin}_{2}$ & Yield \\
\hline 1 & $\mathrm{MeOH} / \mathrm{H}_{2} \mathrm{O} 100: 1,50^{\circ} \mathrm{C}$ & & & $\begin{array}{l}29.3 \% \\
\text { (Isolated) }\end{array}$ \\
\hline
\end{tabular}




\begin{tabular}{|l|l|l|l|l|}
\hline 2 & $\mathrm{MeOH} / \mathrm{H}_{2} \mathrm{O} 100: 1$ & $85.4 \%$ & $92.4 \%$ & $17.7 \%$ \\
\hline 3 & $\mathrm{MeOH} / \mathrm{DMF} 5: 1$ & $91.0 \%$ & $98.7 \%$ & $13.1 \%$ \\
\hline 4 & $\begin{array}{l}\mathrm{MeOH} / \mathrm{H}_{2} \mathrm{O} 100: 1, \\
\mathrm{Cs}_{2} \mathrm{CO}_{3} \text { as base }\end{array}$ & $99.4 \%$ & $99.2 \%$ & $3.1 \%$ \\
\hline 5 & $\mathrm{MeCN} \mathrm{NaNH}_{2}$ & $100 \%$ & $72.9 \%$ & $2.5 \%$ \\
\hline 6 & $\mathrm{DMF}, \mathrm{NaNH}_{2}$ & $100 \%$ & $48.1 \%$ & $\mathrm{ND}$ \\
\hline
\end{tabular}

Procedure B: using $\mathrm{B}_{2} \mathrm{cat}_{2}$.

In a glove box, a vial equipped with a stir bar was charged with base, $B_{2} \mathrm{cat}_{2}(2 \mathrm{mmol}, 476 \mathrm{mg})$, iodocyclohexane $1 \mathbf{u}(0.5 \mathrm{mmol}, 105 \mathrm{mg}, 65 \mu \mathrm{L})$ and the solvent. After removing the sealed vial from the glove box, the reaction mixture was stirred at given temperature for given time. Upon cooling to room temperature, pinacol (4 mmol, $472 \mathrm{mg}$ ) and $\mathrm{Et}_{3} \mathrm{~N}$ (4 mmol, $405 \mathrm{mg}$, $0.56 \mathrm{~mL}$ ) were added and the reaction mixture was stirred at room temperature for at least 3 hours. After that, $n$-decane $(\sim 30 \mathrm{mg})$ was added, the conversion of halide and the yield were measured by GC (FID).

Table S3. Optimization of secondary alkyl halides: using $\mathrm{B}_{2} \mathrm{cat}_{2}$ as reagent.<smiles>IC1CCCCC1</smiles>

$0.5 \mathrm{mmol}$
1) $\mathrm{B}_{2} \mathrm{Cat}_{2}$ (4 equiv.), Solvent $t$-BuOLi (2 equiv.), $\mathrm{T}^{\circ} \mathrm{C}, 48 \mathrm{~h}$ 2) pinacol (8 equiv.), $\mathrm{Et}_{3} \mathrm{~N}$ (8 equiv.), rt, $3 \mathrm{~h}$<smiles>Brc1ccccc1</smiles>

$t$-Bu<smiles>CC(C)(C)c1ccnc(-c2cc(C(C)(C)C)ccn2)c1</smiles>

A1<smiles>N#Cc1ccncc1</smiles>

A2

\begin{tabular}{|l|l|l|l|l|l|}
\hline Entry & Solvent & Volume $(\mathrm{mL})$ & Temperature & Conv. Sub & Yield \\
\hline 1 & MeOH/DMF 10:1 & 0.85 & $50\left(\mathrm{~B}_{2} \mathrm{pin}_{2}\right.$ used $)$ & $42.6 \%$ & $17.3 \%$ \\
\hline 2 & $\mathrm{MeOH} / \mathrm{DMF} 10: 1$ & 0.85 & 50 & $20.8 \%$ & $18.1 \%$ \\
\hline 3 & $\mathrm{MeOH} / \mathrm{DMF} 3: 1$ & 0.85 & 50 & $24.5 \%$ & $17.9 \%$ \\
\hline 4 & $\mathrm{MeOH} / \mathrm{DMF} 1: 1$ & 0.85 & 50 & $28.9 \%$ & $20.7 \%$ \\
\hline 5 & $\mathrm{DMF}$ & 0.85 & 50 & $41.9 \%$ & $10.7 \%$ \\
\hline 6 & $\mathrm{MeOH} / \mathrm{DMF} 10: 1$ & 0.85 & 80 & $88.6 \%$ & $45.7 \%$ \\
\hline 7 & $\mathrm{MeOH} / \mathrm{DMF} 10: 1$ & 0.45 & 80 & $70.0 \%$ & $29.0 \%$ \\
\hline 8 & $\mathrm{MeOH}$ & 0.45 & 80 & $73.9 \%$ & $44.8 \%$ \\
\hline 9 & $\mathrm{MeOH}$ & 0.45 & $80($ With 0.2 equiv. A1) & $75.4 \%$ & $12.0 \%$ \\
\hline 10 & $\mathrm{MeOH}$ & 0.45 & $80($ With 0.2 equiv. A2) & - & Trace \\
\hline 11 & $\mathrm{MeOH}$ & 0.45 & $80(\mathrm{MeOLi}$ as the base $)$ & - & Trace \\
\hline 12 & $\mathrm{MeOH}$ & 0.45 & $80(\mathrm{LiOH}$ as the base $)$ & $86.8 \%$ & $46.1 \%$ \\
\hline $\mathbf{1 3}$ & $\mathbf{M e O H}$ & $\mathbf{0 . 8 5}$ & $\mathbf{8 0}$ & $\mathbf{9 6 . 3 \%}$ & $\mathbf{6 6 . 2 \%}$ \\
\hline 14 & $\mathrm{MeOH}$ & 0.85 & $80(\mathrm{LiOH}$ as the base) & $93.2 \%$ & $51.1 \%$ \\
\hline
\end{tabular}




\begin{tabular}{|l|l|l|l|l|l|}
\hline 15 & $\mathrm{MeOH}$ & 1.5 & 80 & $96.3 \%$ & $53.3 \%$ \\
\hline 16 & $\mathrm{MeOH}$ & 2 & 80 & $97.5 \%$ & $36.3 \%$ \\
\hline
\end{tabular}




\section{Experimental procedures and characterization data}

\subsection{Procedure for borylation of primary alkyl halides}

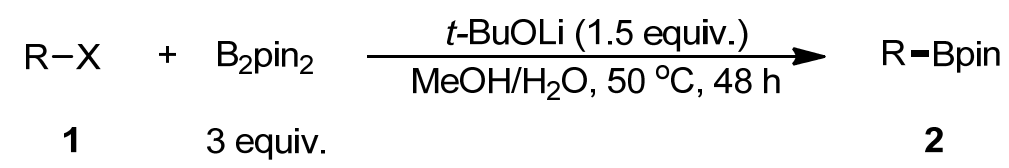

In a glove box, a vial equipped with a stir bar was charged with $t$-BuOLi $(0.75 \mathrm{mmol}, 1.5$ equiv., $60.1 \mathrm{mg}), \mathrm{B}_{2} \operatorname{pin}_{2}(1.5 \mathrm{mmol}, 3$ equiv., $380.9 \mathrm{mg})$, alkyl halide $1(0.5 \mathrm{mmol})$, and a mixture of methanol $(0.85 \mathrm{~mL})$ and $\mathrm{H}_{2} \mathrm{O}(10 \mu \mathrm{L})$ as solvent. After removing the sealed vial from the glove box, the reaction mixture was stirred at $50{ }^{\circ} \mathrm{C}$ for $48 \mathrm{~h}$. Upon cooling to room temperature, the reaction mixture was transferred to a $100 \mathrm{~mL}$ flask by methanol, and then a little silica gel was added into it. After removal of the solvent in vacuo, the residue was poured onto a silica gel column and purified by column chromatography to give the desired product 2.

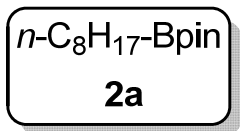

$99.3 \mathrm{mg}, 83 \%$ isolated yield. Colorless liquid. ${ }^{1} \mathrm{H}$ NMR (400 MHz, $\left.\mathrm{CDCl}_{3}\right): \delta 1.32(\mathrm{q}, J=7.3 \mathrm{~Hz}, 2 \mathrm{H}), 1.27-1.04(\mathrm{~m}, 22 \mathrm{H}), 0.80(\mathrm{t}, J=6.8$ $\mathrm{Hz}, 3 \mathrm{H}), 0.69$ (t, J = 7.7 Hz, 2H). ${ }^{13} \mathrm{C} \mathrm{NMR}\left(101 \mathrm{MHz}, \mathrm{CDCl}_{3}\right) \delta 82.79,32.43,31.89,29.37$, 29.25, 24.79, 23.99, 22.67, 14.10. $\mathrm{Rf}=0.65$ (PE/EA 10:1), using PE/EA 50:1 30:1 as eluent. $^{18}$

$\mathrm{CH}_{3}$-Bpin $42 \%$ GC-FID yield. Highly volatile that couldn't be isolated. Standard 2b curve was obtained with the authentic sample. Colorless liquid. GC-MS data: Calcd. $\mathrm{C}_{7} \mathrm{H}_{15} \mathrm{BO}_{2}{ }^{+}[\mathrm{M}]^{+}:$142.1. Found: $142.1,127.1\left(\mathrm{M}-\mathrm{CH}_{3}\right) .{ }^{19}$

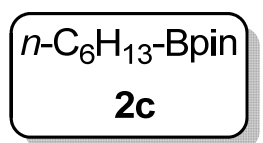

$52.0 \mathrm{mg}, 49 \%$ isolated yield. Colorless liquid. ${ }^{1} \mathrm{H}$ NMR $(400 \mathrm{MHz}$, $\left.\mathrm{CDCl}_{3}\right): \delta 1.39-1.27(\mathrm{~m}, 2 \mathrm{H}), 1.26-1.09(\mathrm{~m}, 18 \mathrm{H}), 0.86-0.75(\mathrm{~m}$, $3 \mathrm{H}), 0.70(\mathrm{t}, J=7.7 \mathrm{~Hz}, 2 \mathrm{H}) \cdot{ }^{13} \mathrm{C} \mathrm{NMR}\left(101 \mathrm{MHz}, \mathrm{CDCl}_{3}\right) \delta 82.79$, 32.08, 31.63, 24.79, 23.95, 22.57, 14.07. $\mathrm{Rf}=0.65(\mathrm{PE} / \mathrm{EA} 10: 1)$, using PE/EA 50:1 30:1 as eluent. ${ }^{20}$ 
$1.39(\mathrm{q}, J=7.1 \mathrm{~Hz}, 2 \mathrm{H}), 1.34-1.16(\mathrm{~m}, 24 \mathrm{H}), 0.87(\mathrm{t}, J=6.8 \mathrm{~Hz}, 3 \mathrm{H}), 0.77(\mathrm{t}, J=7.7 \mathrm{~Hz}$, 2H). ${ }^{13} \mathrm{C} \mathrm{NMR}\left(101 \mathrm{MHz}, \mathrm{CDCl}_{3}\right) \delta 82.80,32.43,31.91,29.54,29.42,29.33,24.80,24.00$, 22.69, 14.11. $\mathrm{Rf}=0.7(\mathrm{PE} / \mathrm{EA} \mathrm{10:1})$, using PE/EA 50:1 30:1 as eluent. ${ }^{21}$

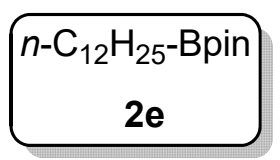

$100.2 \mathrm{mg}, 68 \%$ isolated yield ( $118.7 \mathrm{mg}, 80 \%$ isolated yield). White solid. ${ }^{1} \mathrm{H}$ NMR (400 MHz, $\left.\mathrm{CDCl}_{3}\right) \delta 1.45-1.35(\mathrm{~m}, 2 \mathrm{H}), 1.34-1.15$ (m, $30 \mathrm{H}), 0.88(\mathrm{t}, J=6.8 \mathrm{~Hz}, 3 \mathrm{H}), 0.76(\mathrm{t}, J=7.7 \mathrm{~Hz}, 2 \mathrm{H}) .{ }^{13} \mathrm{C} \mathrm{NMR}(101$ $\left.\mathrm{MHz}, \mathrm{CDCl}_{3}\right) \delta 82.81,32.45,31.93,29.70,29.67,29.60,29.42,29.37,24.81,24.01,22.69$, 14.12. $\mathrm{Rf}=0.7(\mathrm{PE} / \mathrm{EA} 10: 1)$, using PE/EA 100:1 35:1 as eluent. ${ }^{22}$

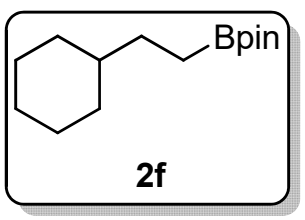

$73.3 \mathrm{mg}$, 62\% isolated yield (101.4 mg, 85\% isolated yield). Colorless liquid. ${ }^{1} \mathrm{H}$ NMR (400 MHz, $\left.\mathrm{CDCl}_{3}\right): \delta 1.72-1.49$ (m, 5H), $1.30-$ $0.95(\mathrm{~m}, 18 \mathrm{H}), 0.78(\mathrm{td}, J=11.6,2.9 \mathrm{~Hz}, 2 \mathrm{H}), 0.72-0.61(\mathrm{~m}, 2 \mathrm{H})$. ${ }^{13} \mathrm{C} \mathrm{NMR}\left(101 \mathrm{MHz}, \mathrm{CDCl}_{3}\right) \delta 82.79,39.94,32.97,31.36,26.76,26.43,24.79 . \mathrm{Rf}=0.4(\mathrm{PE})$, using PE as eluent. ${ }^{23}$

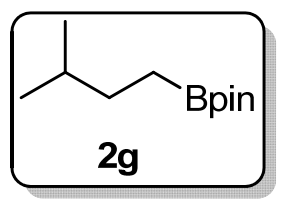

$62.0 \mathrm{mg}, 63 \%$ isolated yield ( $29.4 \mathrm{mg}, 30 \%$ isolated yield using bromide). Colorless liquid. ${ }^{1} \mathrm{H}$ NMR (400 MHz, $\left.\mathrm{CDCl}_{3}\right): \delta 1.39$ (dq, $J=13.3,6.6$ $\mathrm{Hz}, 1 \mathrm{H}), 1.29-1.19(\mathrm{~m}, 2 \mathrm{H}), 1.17(\mathrm{~s}, 12 \mathrm{H}), 0.79$ (d, $J=6.6 \mathrm{~Hz}, 6 \mathrm{H})$, $0.72-0.62(\mathrm{~m}, 2 \mathrm{H}) .{ }^{13} \mathrm{C} \mathrm{NMR}\left(101 \mathrm{MHz}, \mathrm{CDCl}_{3}\right) \delta 82.83$, 32.91, 30.21, 24.81, 22.20. $\mathrm{Rf}=$ 0.55 (PE/EA 10:1), using PE/ $\mathrm{Et}_{2} \mathrm{O} 20: 1 \sim 10: 1$ as eluent. ${ }^{18}$

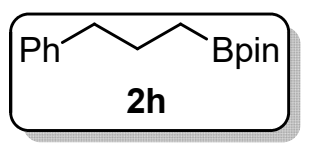

$65.7 \mathrm{mg}$, 53\% isolated yield (75.1 mg, 61\% isolated yield). Colorless liquid. ${ }^{1} \mathrm{H}$ NMR $\left(400 \mathrm{MHz}, \mathrm{CDCl}_{3}\right) \delta 7.32-7.20(\mathrm{~m}, 2 \mathrm{H}), 7.16(\mathrm{dd}, J$ $=7.9,2.9 \mathrm{~Hz}, 3 \mathrm{H}), 2.71-2.52(\mathrm{~m}, 2 \mathrm{H}), 1.73(\mathrm{p}, J=7.8 \mathrm{~Hz}, 2 \mathrm{H}), 1.24$ (s, 12H), $0.82(\mathrm{t}, J=7.9 \mathrm{~Hz}, 2 \mathrm{H}) .{ }^{13} \mathrm{C} \mathrm{NMR}\left(101 \mathrm{MHz}, \mathrm{CDCl}_{3}\right) \delta 142.70,128.57,128.18$, $125.58,82.95,38.62,26.14,24.86 . \mathrm{Rf}=0.6(\mathrm{PE} / \mathrm{EA} 10: 1)$, using PE/EA 40:1 as eluent. $^{24}$

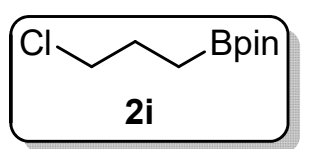

$41.3 \mathrm{mg}$, 41\% isolated yield (76.4 mg, 75\% isolated yield). Colorless liquid. ${ }^{1} \mathrm{H} \mathrm{NMR}\left(400 \mathrm{MHz}, \mathrm{CDCl}_{3}\right), \delta 3.53(\mathrm{t}, J=6.9 \mathrm{~Hz}, 2 \mathrm{H}), 2.00-$ $1.79(\mathrm{~m}, 2 \mathrm{H}), 1.25(\mathrm{~s}, 12 \mathrm{H}), 0.91(\mathrm{t}, J=7.8 \mathrm{~Hz}, 2 \mathrm{H}) .{ }^{13} \mathrm{C}$ NMR $(101$ $\left.\mathrm{MHz}_{\mathrm{CDCl}}\right) \delta 83.16,47.12,27.31,25.02,24.80 . \mathrm{Rf}=0.55(\mathrm{PE} / \mathrm{EA} \mathrm{10:1)}$, using PE/EA 50:1 30:1 as eluent. ${ }^{25}$ 


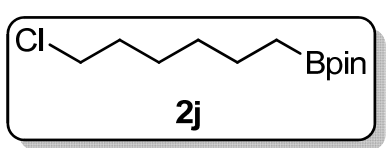

$84.2 \mathrm{mg}, 68 \%$ isolated yield. Colorless liquid. ${ }^{1} \mathrm{H}$ NMR (400 $\left.\mathrm{MHz}, \mathrm{CDCl}_{3}\right), \delta 3.52(\mathrm{t}, J=6.8 \mathrm{~Hz}, 2 \mathrm{H}), 1.76(\mathrm{p}, J=7.0 \mathrm{~Hz}, 2 \mathrm{H})$ $1.42(\mathrm{p}, J=7.5 \mathrm{~Hz}, 4 \mathrm{H}), 1.36-1.28(\mathrm{~m}, 2 \mathrm{H}), 1.24(\mathrm{~s}, 12 \mathrm{H}), 0.77$ $(\mathrm{t}, J=7.6 \mathrm{~Hz}, 2 \mathrm{H}) .{ }^{13} \mathrm{C} \mathrm{NMR}\left(101 \mathrm{MHz}, \mathrm{CDCl}_{3}\right) \delta 82.88,45.12,32.53,31.52,26.62,24.81$, 23.78. $\mathrm{Rf}=0.6\left(\mathrm{PE} / \mathrm{EA} \mathrm{10:1)}\right.$, using PE/EA 50:1 30:1 as eluent. ${ }^{18}$

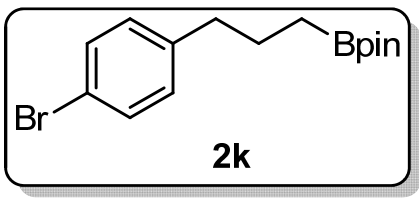

$69.5 \mathrm{mg}$, 43\% isolated yield. Colorless liquid. ${ }^{1} \mathrm{H}$ NMR (400 $\left.\mathrm{MHz}, \mathrm{CDCl}_{3}\right), \delta 7.37(\mathrm{~d}, J=8.3 \mathrm{~Hz}, 2 \mathrm{H}), 7.04(\mathrm{~d}, J=8.4 \mathrm{~Hz}$ $2 \mathrm{H}), 2.61-2.48(\mathrm{~m}, 2 \mathrm{H}), 1.78-1.64(\mathrm{~m}, 2 \mathrm{H}), 1.24(\mathrm{~s}, 12 \mathrm{H})$, $0.80(\mathrm{t}, J=7.9 \mathrm{~Hz}, 2 \mathrm{H}) .{ }^{13} \mathrm{C} \mathrm{NMR}\left(101 \mathrm{MHz}, \mathrm{CDCl}_{3}\right) \delta 141.60,131.20,130.34,119.28$, 83.01, 37.90, 25.91, 24.84. ${ }^{11} \mathrm{~B}$ NMR $\left(160 \mathrm{MHz}, \mathrm{CDCl}_{3}\right) \delta 34.04 . \mathrm{IR}: v=2977,2930,1488$, $1459,1404,1371,1318,1269,1226,1165,1143,1109,1072,1011,968,875,847,814,785$, $512 \mathrm{~cm}^{-1}$. HRMS: Calcd. $\mathrm{C}_{15} \mathrm{H}_{23} \mathrm{BBrO}_{2}{ }^{+}[\mathrm{M}+\mathrm{H}]^{+}$: 325.0969. Found: 325.0971. Calcd. $\mathrm{C}_{15} \mathrm{H}_{26} \mathrm{BBrNO}_{2}{ }^{+}\left[\mathrm{M}+\mathrm{NH}_{4}\right]^{+}:$342.1234. Found: 342.1232. $\mathrm{Rf}=0.55(\mathrm{PE} / \mathrm{EA} 10: 1)$, using PE/EA 50:1 as eluent.

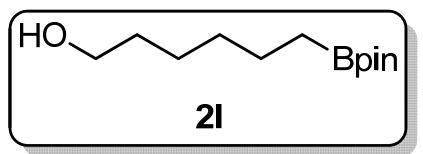

$82.1 \mathrm{mg}, 72 \%$ isolated yield. Colorless liquid. ${ }^{1} \mathrm{H}$ NMR (400 $\left.\mathrm{MHz}, \mathrm{CDCl}_{3}\right): \delta 3.63(\mathrm{t}, J=6.6 \mathrm{~Hz}, 2 \mathrm{H}), 1.56(\mathrm{p}, J=6.9 \mathrm{~Hz}$, $3 \mathrm{H}), 1.46-1.38(\mathrm{~m}, 2 \mathrm{H}), 1.33(\mathrm{dd}, J=7.3,3.7 \mathrm{~Hz}, 4 \mathrm{H}), 1.24(\mathrm{~s}$, $12 \mathrm{H}), 0.78(\mathrm{t}, J=7.6 \mathrm{~Hz}, 2 \mathrm{H}) .{ }^{13} \mathrm{C} \mathrm{NMR}\left(101 \mathrm{MHz}, \mathrm{CDCl}_{3}\right) \delta 82.88,63.00,32.67,32.05$, 25.43, 24.80, 23.90. ${ }^{11} \mathrm{~B}$ NMR $\left(160 \mathrm{MHz}, \mathrm{CDCl}_{3}\right) \delta 34.01 . \mathrm{IR}: v=3370,2977,2928,2858$, $1464,1372,1317,1273,1214,1165,1144,1111,1056,968,882,847,721,674,579 \mathrm{~cm}^{-1}$. HRMS: Calcd. $\mathrm{C}_{12} \mathrm{H}_{26} \mathrm{BO}_{3}{ }^{+}[\mathrm{M}+\mathrm{H}]^{+}$: 229.1970. Found: 229.1967. Calcd. $\mathrm{C}_{12} \mathrm{H}_{29} \mathrm{BNO}_{3}{ }^{+}$ $\left[\mathrm{M}+\mathrm{NH}_{4}\right]^{+}:$246.2235. Found: 246.2233. $\mathrm{Rf}=0.2($ PE/EA 5:1), using PE/EA 15:1 5:1 as eluent.

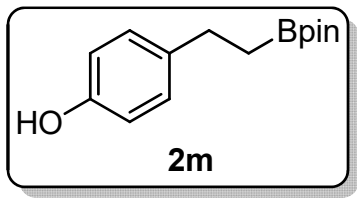

$50.8 \mathrm{mg}, 41 \%$ isolated yield. Colorless liquid. ${ }^{1} \mathrm{H}$ NMR (400 MHz, $\left.\mathrm{CDCl}_{3}\right) \delta 7.06(\mathrm{~d}, J=8.2 \mathrm{~Hz}, 2 \mathrm{H}), 6.72(\mathrm{~d}, J=8.1 \mathrm{~Hz}, 2 \mathrm{H}), 5.44-$ $4.83(\mathrm{~m}, 1 \mathrm{H}), 2.67(\mathrm{t}, J=8.1 \mathrm{~Hz}, 2 \mathrm{H}), 1.22(\mathrm{~s}, 12 \mathrm{H}), 1.11(\mathrm{t}, J=$ $8.1 \mathrm{~Hz}, 2 \mathrm{H}) .{ }^{13} \mathrm{C}$ NMR $\left(101 \mathrm{MHz}, \mathrm{CDCl}_{3}\right) \delta 153.51,136.41,129.07,115.01,83.25,29.03$, 24.80. ${ }^{11} \mathrm{~B}$ NMR $\left(160 \mathrm{MHz}, \mathrm{CDCl}_{3}\right) \delta 33.84 . \mathrm{IR}: v=3385,2978,2930,1614,1595,1514$, $1447,1371,1315,1215,1168,1140,1107,1089,966,879,840,828,777,715,674,579,552$, 
528, $436 \mathrm{~cm}^{-1}$. HRMS: Calcd. $\mathrm{C}_{14} \mathrm{H}_{22} \mathrm{BO}_{3}{ }^{+}[\mathrm{M}+\mathrm{H}]^{+}$: 249.1657. Found: 249.1663. Calcd. $\mathrm{C}_{14} \mathrm{H}_{25} \mathrm{BNO}_{3}{ }^{+}\left[\mathrm{M}+\mathrm{NH}_{4}\right]^{+}:$266.1922. Found: 266.1928. $\mathrm{Rf}=0.4$ (PE/EA 10:1). Using PE/EA 15:1 10:1 as eluent.

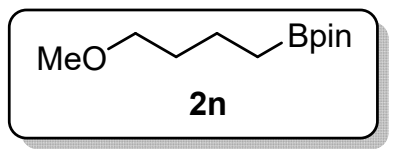

$43.9 \mathrm{mg}, 41 \%$ isolated yield. $48 \%$ NMR yield. The polarity $(\mathrm{Rf}=$ 0.4 using PE/EA 10:1) is relatively close to $\mathrm{B}_{2} \operatorname{pin}_{2}$ that couldn't be fully purified. ${ }^{1} \mathrm{H} \mathrm{NMR}\left(400 \mathrm{MHz}, \mathrm{CDCl}_{3}\right) \delta 3.36(\mathrm{t}, J=6.6$ $\mathrm{Hz}, 2 \mathrm{H}), 3.32(\mathrm{~s}, 3 \mathrm{H}), 1.61-1.53(\mathrm{~m}, 2 \mathrm{H}), 1.51-1.41(\mathrm{~m}, 2 \mathrm{H}), 1.24(\mathrm{~s}, 12 \mathrm{H}), 0.80(\mathrm{t}, J=$ $7.8 \mathrm{~Hz}, 2 \mathrm{H}) .{ }^{13} \mathrm{C} \mathrm{NMR}\left(101 \mathrm{MHz}, \mathrm{CDCl}_{3}\right) \delta 82.92,72.72,58.48,32.13,24.82,20.57 . \mathrm{Rf}=$ 0.4 (PE/EA 10:1), using PE/EA 15:1 10:1 as eluent. NMR Yield was measured by ${ }^{1} \mathrm{H}$ NMR via the ratio of the total area of the signals in $\delta 3.36(2 \mathrm{H})$ and $3.32(3 \mathrm{H})$, with the signal of $\mathrm{C}_{2} \mathrm{H}_{2} \mathrm{Cl}_{4}(49.2 \mathrm{mg}$ added, signal in $\delta 5.96,2 \mathrm{H})$. GC-MS data: Calcd. $\mathrm{C}_{11} \mathrm{H}_{23} \mathrm{BO}_{3}{ }^{+}$ $[\mathrm{M}]^{+}:$214.2. Found: 214.1, $199.1\left(\mathrm{M}-\mathrm{CH}_{3}\right){ }^{26}$

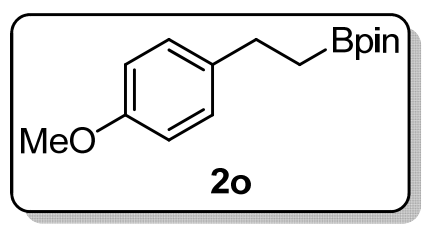

$76.4 \mathrm{mg}$, 58\% isolated yield. White solid. ${ }^{1} \mathrm{H}$ NMR (400 MHz, $\left.\mathrm{CDCl}_{3}\right) \delta 7.13(\mathrm{~d}, J=8.4 \mathrm{~Hz}, 2 \mathrm{H}), 6.80(\mathrm{~d}, J=8.6 \mathrm{~Hz}, 2 \mathrm{H})$, $3.77(\mathrm{~s}, 3 \mathrm{H}), 2.76-2.61(\mathrm{~m}, 2 \mathrm{H}), 1.22(\mathrm{~s}, 12 \mathrm{H}), 1.16-1.06$ (m, 2H). ${ }^{13} \mathrm{C} \mathrm{NMR}\left(101 \mathrm{MHz}, \mathrm{CDCl}_{3}\right) \delta 157.54,136.57,128.86,113.59,83.07,55.25,29.06$, 24.83. $\mathrm{Rf}=0.6(\mathrm{PE} / \mathrm{EA} 10: 1)$, using PE/EA 30:1 as eluent. ${ }^{25}$

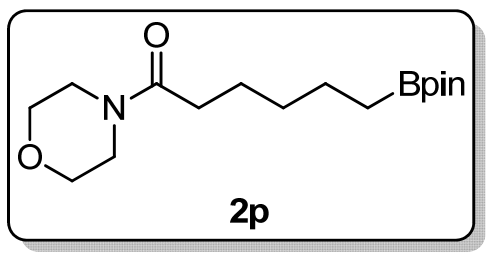

$121.2 \mathrm{mg}, 78 \%$ isolated yield. Pale-yellow liquid. ${ }^{1} \mathrm{H}$ NMR $\left(400 \mathrm{MHz}, \mathrm{CDCl}_{3}\right) \delta 3.74-3.64(\mathrm{~m}, 4 \mathrm{H}), 3.61(\mathrm{~d}, J=5.4$ $\mathrm{Hz}, 2 \mathrm{H}), 3.46(\mathrm{t}, J=4.8 \mathrm{~Hz}, 2 \mathrm{H}), 2.35-2.25(\mathrm{~m}, 2 \mathrm{H})$, $1.63(\mathrm{p}, J=7.5 \mathrm{~Hz}, 2 \mathrm{H}), 1.50-1.32(\mathrm{~m}, 4 \mathrm{H}), 1.24(\mathrm{~s}$, $12 \mathrm{H}), 0.78(\mathrm{t}, J=7.7 \mathrm{~Hz}, 2 \mathrm{H}) .{ }^{13} \mathrm{C} \mathrm{NMR}\left(101 \mathrm{MHz}, \mathrm{CDCl}_{3}\right) \delta 171.90,82.90,66.96,66.70$, 46.06, 41.84, 33.10, 32.19, 25.06, 24.82, 23.74. ${ }^{11} \mathrm{~B}$ NMR (160 MHz, $\left.\mathrm{CDCl}_{3}\right) \delta 34.15$. IR: $v=$ 2975, 2926, 2856, 1645, 1427, 1371, 1319, 1272, 1247, 1226, 1166, 1145, 1115, 1069, 1029, 968, 847, $578 \mathrm{~cm}^{-1}$. HRMS: Calcd. $\mathrm{C}_{16} \mathrm{H}_{31} \mathrm{BNO}_{4}{ }^{+}[\mathrm{M}+\mathrm{H}]^{+}:$312.2341. Found: 312.2348. $\mathrm{Rf}=$ 0.55 (DCM/MeOH 20:1), using DCM/MeOH 1:0 30:1 as eluent.

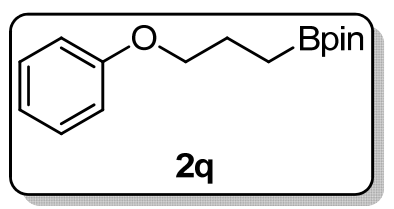

$67.5 \mathrm{mg}, 52 \%$ isolated yield ( $85.2 \mathrm{mg}, 65 \%$ isolated yield). Colorless liquid. ${ }^{1} \mathrm{H}$ NMR $\delta 7.24-7.11(\mathrm{~m}, 2 \mathrm{H}), 6.89-6.75(\mathrm{~m}$, 
$3 \mathrm{H}), 3.85(\mathrm{t}, J=6.7 \mathrm{~Hz}, 2 \mathrm{H}), 1.91-1.72(\mathrm{~m}, 2 \mathrm{H}), 1.16(\mathrm{~s}, 12 \mathrm{H}), 0.84(\mathrm{t}, J=7.8 \mathrm{~Hz}, 2 \mathrm{H}) .{ }^{13} \mathrm{C}$ $\operatorname{NMR}\left(101 \mathrm{MHz}, \mathrm{CDCl}_{3}\right) \delta 158.11,128.29,119.31,113.53,82.03,68.44,23.80,22.74 . \mathrm{Rf}=$ 0.75 (PE/EA 5:1), using PE/EA 50:1 30:1 as eluent. ${ }^{27}$

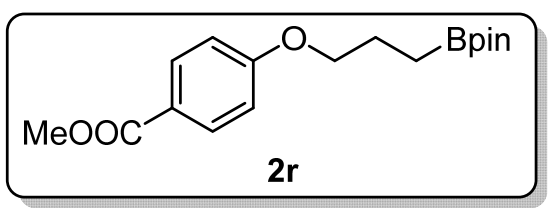

$41 \%$ NMR yield. The polarity $(\mathrm{Rf}=0.5$ using $\mathrm{PE} / \mathrm{EA}$ 5:1) is same with $B_{2}$ pin $_{2}$ that couldn't be purified. Yield was measured by ${ }^{1} \mathrm{H}$ NMR via the ratio of the average area of the signals in $\delta 7.97(2 \mathrm{H}), 6.91(2 \mathrm{H}), 3.99(2 \mathrm{H})$ with the signal of $\mathrm{C}_{2} \mathrm{H}_{2} \mathrm{Cl}_{4}(65.9 \mathrm{mg}$ added, signal in $\delta 5.96,2 \mathrm{H})$. GC-MS data: Calcd. $\mathrm{C}_{17} \mathrm{H}_{25} \mathrm{BO}_{5}{ }^{+}[\mathrm{M}]^{+}$: 320.2. Found: 320.2, $305.2\left(\mathrm{M}-\mathrm{CH}_{3}\right)$. Standard sample was prepared according to the procedure in the end of Section 4.1. ${ }^{1} \mathrm{H}$ NMR $\left(400 \mathrm{MHz}, \mathrm{CDCl}_{3}\right) \delta 7.97(\mathrm{~d}, J=8.9 \mathrm{~Hz}, 2 \mathrm{H}), 6.91(\mathrm{~d}, J=8.9 \mathrm{~Hz}, 2 \mathrm{H})$, $3.99(\mathrm{t}, J=6.7 \mathrm{~Hz}, 2 \mathrm{H}), 3.88(\mathrm{~s}, 3 \mathrm{H}), 1.91(\mathrm{p}, J=7.0 \mathrm{~Hz}, 2 \mathrm{H}), 1.25(\mathrm{~s}, 12 \mathrm{H}), 0.93(\mathrm{t}, J=7.8$ $\mathrm{Hz}, 2 \mathrm{H})$.

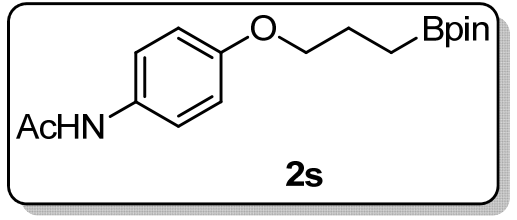

$110.0 \mathrm{mg}, 69 \%$ isolated yield. White solid. ${ }^{1} \mathrm{H}$ NMR (400 $\left.\mathrm{MHz}, \mathrm{CDCl}_{3}\right) \delta 7.61(\mathrm{~s}, 1 \mathrm{H}), 7.37(\mathrm{~d}, \mathrm{~J}=8.9 \mathrm{~Hz}, 2 \mathrm{H})$, $6.83(\mathrm{~d}, J=8.9 \mathrm{~Hz}, 2 \mathrm{H}), 3.90(\mathrm{t}, \mathrm{J}=6.7 \mathrm{~Hz}, 2 \mathrm{H}), 2.12(\mathrm{~s}$, $3 \mathrm{H}), 1.88(\mathrm{p}, \mathrm{J}=7.1 \mathrm{~Hz}, 2 \mathrm{H}), 1.25(\mathrm{~s}, 12 \mathrm{H}), 0.91(\mathrm{t}, \mathrm{J}=7.8 \mathrm{~Hz}, 2 \mathrm{H}) \cdot{ }^{13} \mathrm{C}$ NMR (101 MHz, $\left.\mathrm{CDCl}_{3}\right) \delta 168.43,155.97,130.82,121.89,114.79,83.12,69.86,24.85,24.29,23.73 .{ }^{11} \mathrm{~B}$ NMR (160 MHz, $\left.\mathrm{CDCl}_{3}\right) \delta 33.94$ IR: $v=3295,2977,2930,1660,1604,1544,1510,1471$, $1411,1371,1317,1240,1168,1144,1111,1018,968,912,846,829,674,578,543,521 \mathrm{~cm}^{-1}$. HRMS: Calcd. $\mathrm{C}_{17} \mathrm{H}_{27} \mathrm{BNO}_{4}{ }^{+}[\mathrm{M}+\mathrm{H}]^{+}$: 320.2028. Found: 320.2027. Calcd. $\mathrm{C}_{17} \mathrm{H}_{30} \mathrm{BN}_{2} \mathrm{O}_{4}{ }^{+}$ $\left[\mathrm{M}+\mathrm{NH}_{4}\right]^{+}:$337.2293. Found: 337.2291 . M.p. $66-68{ }^{\circ} \mathrm{C} . \mathrm{Rf}=0.25$ (PE/EA 1:1), using PE/EA 5:1 1:1 as eluent.

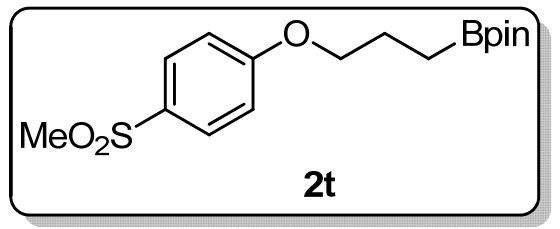

$71.1 \mathrm{mg}, 42 \%$ isolated yield. Colorless liquid. ${ }^{1} \mathrm{H}$ NMR $\left(400 \mathrm{MHz}, \mathrm{CDCl}_{3}\right) \delta 7.85(\mathrm{~d}, \mathrm{~J}=8.9 \mathrm{~Hz}, 2 \mathrm{H}), 7.01(\mathrm{~d}$, $\mathrm{J}=9.0 \mathrm{~Hz}, 2 \mathrm{H}), 4.02(\mathrm{t}, \mathrm{J}=6.7 \mathrm{~Hz}, 2 \mathrm{H}), 3.03(\mathrm{~s}, 3 \mathrm{H})$, $1.92(\mathrm{p}, \mathrm{J}=7.0 \mathrm{~Hz}, 2 \mathrm{H}), 1.26(\mathrm{~s}, 12 \mathrm{H}), 0.93(\mathrm{t}, \mathrm{J}=7.8 \mathrm{~Hz}, 2 \mathrm{H}) \cdot{ }^{13} \mathrm{C} \mathrm{NMR}\left(101 \mathrm{MHz}, \mathrm{CDCl}_{3}\right)$ $\delta 163.34,131.83,129.49,114.98,83.25,70.09,44.91,24.86,23.45$. IR: $v=2977,2923,1595$, $1578,1499,1470,1412,1373,1315,1298,1259,1143,1112,1093,1009,964,845,765,534$, $489 \mathrm{~cm}^{-1}$. HRMS: Calcd. $\mathrm{C}_{16} \mathrm{H}_{25} \mathrm{BO}_{5} \mathrm{SNa}^{+}[\mathrm{M}+\mathrm{Na}]^{+}$: 363.1408. Found: 363.1402. Calcd. 
$\mathrm{C}_{16} \mathrm{H}_{29} \mathrm{BNO}_{5} \mathrm{~S}^{+}\left[\mathrm{M}+\mathrm{NH}_{4}\right]^{+}$: 358.1854. Found: 358.1849. $\mathrm{Rf}=0.65(\mathrm{PE} / \mathrm{EA} \mathrm{1:1})$, using PE/EA 5:1 2:1 as eluent.

Preparation for authentic sample of $\mathbf{2 r}$

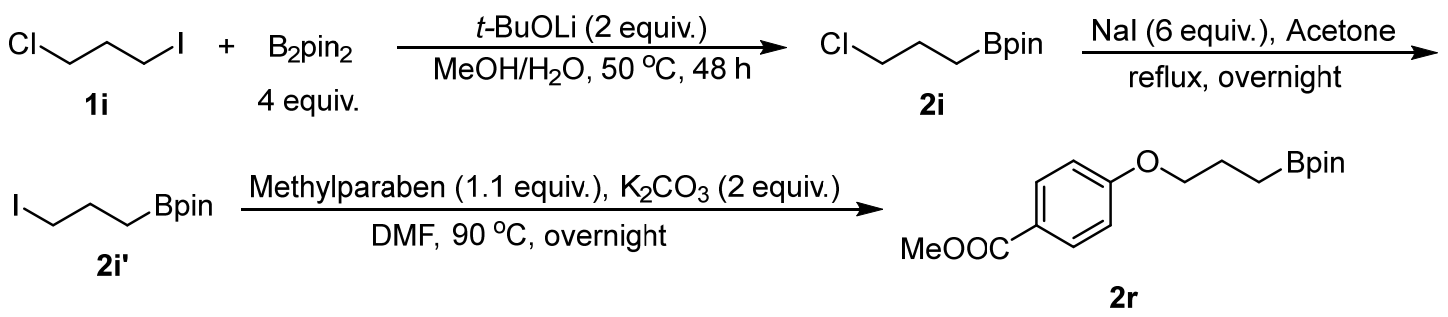

In a well-dried $50 \mathrm{~mL}$ flask, $\mathbf{1 i}(5 \mathrm{mmol}, 1.02 \mathrm{~g}), t$-BuOLi $(10 \mathrm{mmol}, 2$ equiv., $0.80 \mathrm{~g})$ and $\mathrm{B}_{2} \operatorname{pin}_{2}(20 \mathrm{mmol}, 4$ equiv., $5.08 \mathrm{~g})$ were dissolved in a mixed solvent of methanol $(10 \mathrm{~mL})$ and water $(0.1 \mathrm{~mL})$. After the flask was closed, the reaction mixture was stirred at $50{ }^{\circ} \mathrm{C}$ for 48 h. Upon cooling to room temperature, the product $2 \mathbf{i}$ was isolated by column chromatography (silica gel) using PE/EA 50:1 30:1 as eluent. Yield: $0.75 \mathrm{~g}$ (3.67 mmol, 73\%), colorless liquid.

Then, the product $\mathbf{2 i}$ obtained from the former procedure was dissolved in acetone $(5 \mathrm{~mL})$, $\mathrm{NaI}(20 \mathrm{mmol}, 6$ equiv., $3.0 \mathrm{~g})$ was added. The reaction mixture was heated at reflux overnight, following with the solvent was removed under vacuum. Water $(100 \mathrm{~mL})$ was added and the solvent was extracted by EtOAc ( $50 \mathrm{~mL}$ each time) 3 times. The combined organic layer was washed via brine and dried over $\mathrm{Na}_{2} \mathrm{SO}_{4}$, the solvent was removed and the product 2i' was obtained as a yellow liquid. Yield: $0.789 \mathrm{~g}$ (2.66 mmol, 73\%). ${ }^{1} \mathrm{H}$ NMR (400 $\left.\mathrm{MHz}, \mathrm{CDCl}_{3}\right) \delta 3.22(\mathrm{t}, J=7.1 \mathrm{~Hz}, 2 \mathrm{H}), 1.93(\mathrm{p}, J=7.3 \mathrm{~Hz}, 2 \mathrm{H}), 1.24(\mathrm{~s}, 12 \mathrm{H}), 0.92-0.84$ $(\mathrm{m}, 2 \mathrm{H}){ }^{28}$

Finally, the product $2 \mathbf{r}$ was prepared according to the literature procedure. ${ }^{29}$ In a $10 \mathrm{~mL}$ well-dried Schlenk tube, 2i' ( $1 \mathrm{mmol}, 296 \mathrm{mg})$, methylparaben ( $1.1 \mathrm{mmol}, 1.1$ equiv., 167 $\mathrm{mg})$ and $\mathrm{K}_{2} \mathrm{CO}_{3}(2 \mathrm{mmol}, 2$ equiv., $276 \mathrm{mg})$ were dissolved in $\mathrm{DMF}(3 \mathrm{~mL})$. The reaction mixture was stirred at $90{ }^{\circ} \mathrm{C}$ overnight. Upon cooling to room temperature, the reaction mixture was poured into water $(100 \mathrm{~mL})$ and extracted via EtOAc $(50 \mathrm{~mL} * 3)$. After the combined organic layer was washed by brine and dried over $\mathrm{Na}_{2} \mathrm{SO}_{4}$, the solvent was removed and the product $2 \mathbf{r}$ was purified by column chromatography (silica gel) using 
PE/EA 15:1 10:1 as eluent. $51.1 \mathrm{mg}(16 \%)$ of the product was entirely purified as a pale-yellow liquid. ${ }^{1} \mathrm{H}$ NMR $\left(400 \mathrm{MHz}, \mathrm{CDCl}_{3}\right) \delta 7.97(\mathrm{~d}, J=8.9 \mathrm{~Hz}, 2 \mathrm{H}), 6.91(\mathrm{~d}, J=8.9$ $\mathrm{Hz}, 2 \mathrm{H}), 3.99(\mathrm{t}, J=6.7 \mathrm{~Hz}, 2 \mathrm{H}), 3.88(\mathrm{~s}, 3 \mathrm{H}), 1.91(\mathrm{p}, J=7.0 \mathrm{~Hz}, 2 \mathrm{H}), 1.25(\mathrm{~s}, 12 \mathrm{H}), 0.93$ $(\mathrm{t}, J=7.8 \mathrm{~Hz}, 2 \mathrm{H}) .{ }^{13} \mathrm{C} \mathrm{NMR}\left(101 \mathrm{MHz}, \mathrm{CDCl}_{3}\right) \delta 166.94,162.99,131.52,122.22,114.13$, 83.17, 69.75, 51.81, 24.84, 23.58. ${ }^{11} \mathrm{~B} \operatorname{NMR}\left(160 \mathrm{MHz}, \mathrm{CDCl}_{3}\right) \delta 33.98$. IR: $v=2977,2950$, $1716,1605,1578,1511,1469,1435,1372,1317,1277,1251,1190,1166,1143,1103,1011$, 968, 911, 846, 770, 740, 697, 673, 648, 611, 578, $516 \mathrm{~cm}^{-1}$. HRMS: Calcd. $\mathrm{C}_{17} \mathrm{H}_{26} \mathrm{BO}_{5}{ }^{+}$ $[\mathrm{M}+\mathrm{H}]^{+}:$321.1868. Found: 321.1877. $\mathrm{Rf}=0.5(\mathrm{PE} / \mathrm{EA} 5: 1)$.

\subsection{Procedure for borylation of secondary alkyl halides}

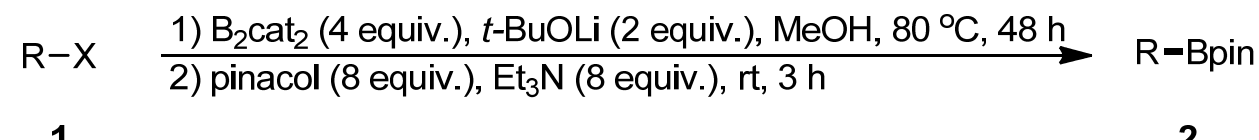

1

2

In a glove box, a vial equipped with a stir bar was charged with $t$-BuOLi ( $1 \mathrm{mmol}, 2$ equiv., $80.1 \mathrm{mg}$ ), $\mathrm{B}_{2} \mathrm{cat}_{2}$ (2 mmol, 4 equiv., $476 \mathrm{mg}$ ), $0.85 \mathrm{~mL}$ methanol as solvent, alkyl halide $\mathbf{1}$ (0.5 $\mathrm{mmol}$ ). After removing the sealed vial from the glove box, the reaction mixture was stirred at $80^{\circ} \mathrm{C}$ for $48 \mathrm{~h}$. Upon cooling to room temperature, pinacol ( $4 \mathrm{mmol}, 8$ equiv., $472 \mathrm{mg}$ ) and $\mathrm{Et}_{3} \mathrm{~N}(4 \mathrm{mmol}, 405 \mathrm{mg}, 0.56 \mathrm{~mL}$ ) were added and the reaction mixture was stirred at room temperature for at least $3 \mathrm{~h}$. After that, the reaction mixture was transferred to a $100 \mathrm{~mL}$ flask by methanol, and then a little silica gel was added into it. After removal of the solvent in vacuo, the residue was poured onto a silica gel column and purified by column chromatography to give the desired product $\mathbf{2}$.

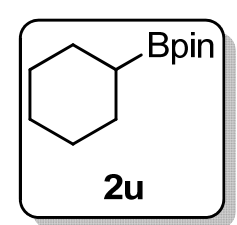

$57.7 \mathrm{mg}, 55 \%$ isolated yield. Colorless liquid. ${ }^{1} \mathrm{H}$ NMR $(400 \mathrm{MHz}$, Chloroform- $d$ ) $\delta 1.65-1.46(\mathrm{~m}, 5 \mathrm{H}), 1.33-1.18(\mathrm{~m}, 5 \mathrm{H}), 1.16(\mathrm{~s}, 12 \mathrm{H})$, $0.97-0.84(\mathrm{~m}, 1 \mathrm{H}) \cdot{ }^{13} \mathrm{C} \mathrm{NMR}\left(101 \mathrm{MHz}, \mathrm{CDCl}_{3}\right) \delta 82.72$, 27.96, 27.14, 26.76, 24.75. $\mathrm{Rf}=0.7(\mathrm{PE} / \mathrm{EA} 10: 1)$, using PE/EA 50:1 30:1 as eluent. ${ }^{18}$

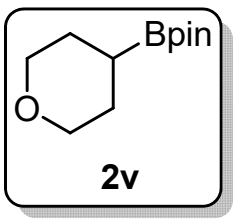

$57.8 \mathrm{mg}, 55 \%$ isolated yield. Colorless liquid. ${ }^{1} \mathrm{H} \mathrm{NMR}\left(400 \mathrm{MHz}, \mathrm{CDCl}_{3}\right)$ $\delta 3.89-3.73(\mathrm{~m}, 2 \mathrm{H}), 3.55-3.36(\mathrm{~m}, 2 \mathrm{H}), 1.73-1.52(\mathrm{~m}, 4 \mathrm{H}), 1.25-$ $1.19(\mathrm{~m}, 13 \mathrm{H}) .{ }^{13} \mathrm{C} \mathrm{NMR}\left(101 \mathrm{MHz}, \mathrm{CDCl}_{3}\right) \delta 83.13,81.56,68.84,29.70$, 


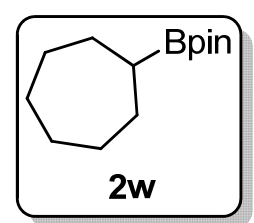

$57.3 \mathrm{mg}, 51 \%$ isolated yield. Colorless liquid. ${ }^{1} \mathrm{H}$ NMR (400 MHz, Chloroform- $d$ ) $\delta 1.84-1.36(\mathrm{~m}, 12 \mathrm{H}), 1.24(\mathrm{~s}, 12 \mathrm{H}), 1.07(\mathrm{dq}, J=9.4,4.9$ $\mathrm{Hz}, 1 \mathrm{H}) .{ }^{13} \mathrm{C} \mathrm{NMR}\left(101 \mathrm{MHz}, \mathrm{CDCl}_{3}\right) \delta 82.75,29.60,28.98,28.34,24.74$. $\mathrm{Rf}=0.7(\mathrm{PE} / \mathrm{EA} 10: 1)$, using PE/EA 50:1 30:1 as eluent. ${ }^{30}$

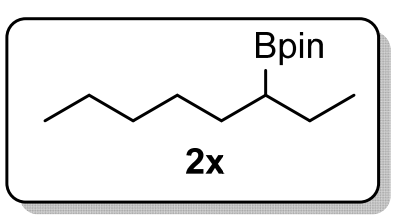

$33 \%$ GC-FID yield (comparing with the purified product and decane). $10.9 \mathrm{mg}$, 9\% isolated yield. Slight volatile colorless oil. GC-MS data: Calcd. $\mathrm{C}_{14} \mathrm{H}_{29} \mathrm{BO}_{2}{ }^{+}[\mathrm{M}]^{+}$: 240.2. Found: 240.2, $225.2\left({\left.\mathrm{M}-\mathrm{CH}_{3}\right) .}^{1} \mathrm{H} \mathrm{NMR}\left(400 \mathrm{MHz}, \mathrm{CDCl}_{3}\right) \delta 1.47-1.18(\mathrm{~m}, 22 \mathrm{H}), 1.00-0.80(\mathrm{~m}, 7 \mathrm{H})\right.$. ${ }^{13} \mathrm{C}$ NMR $\left(101 \mathrm{MHz}, \mathrm{CDCl}_{3}\right) \delta 82.77,32.16,31.13,29.71,28.94,24.81,24.32,22.63,14.08$, 13.75. ${ }^{11} \mathrm{~B}$ NMR $\left(160 \mathrm{MHz}, \mathrm{CDCl}_{3}\right) \delta 34.60 . \mathrm{IR}: v=2957,2923,2855,1633,1466,1410$, 1387, 1379, 1371, 1313, 1266, 1214, 1145, 1026, 967, 859, 791, 685, $578 \mathrm{~cm}^{-1}$. HRMS (gas chromatography): Calcd. $\mathrm{C}_{14} \mathrm{H}_{29} \mathrm{BO}_{2}{ }^{+}[\mathrm{M}]^{+}:$240.2255. Found: 240.2256. Calcd. $\mathrm{C}_{13} \mathrm{H}_{26} \mathrm{BO}_{2}{ }^{+}$ $\left[\mathrm{M}-\mathrm{CH}_{3}\right]^{+}:$225.2020. Found: 225.2025. Rf = 0.8 (PE/EA 10:1), using PE as eluent.

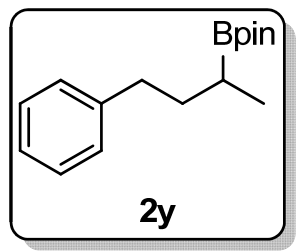

$91.9 \mathrm{mg}, 71 \%$ isolated yield. Colorless liquid. ${ }^{1} \mathrm{H}$ NMR $(400 \mathrm{MHz}$, $\left.\mathrm{CDCl}_{3}\right) \delta 7.63-6.94(\mathrm{~m}, 5 \mathrm{H}), 2.62(\mathrm{t}, J=8.1 \mathrm{~Hz}, 2 \mathrm{H}), 1.68(\mathrm{dt}, J=$ 76.0, 8.0 Hz, 2H), $1.25(\mathrm{~s}, 12 \mathrm{H}), 1.02(\mathrm{~d}, J=6.6 \mathrm{~Hz}, 4 \mathrm{H}) \cdot{ }^{13} \mathrm{C} \mathrm{NMR}$ $\left(101 \mathrm{MHz}, \mathrm{CDCl}_{3}\right) \delta 143.10,128.46,128.22,125.53,82.92,35.35$, 24.83, 24.78, 15.46. $\mathrm{Rf}=0.6(\mathrm{PE} / \mathrm{EA} 10: 1)$, using PE/EA 50:1 30:1 as eluent. ${ }^{22}$

\subsection{Large scale reaction}

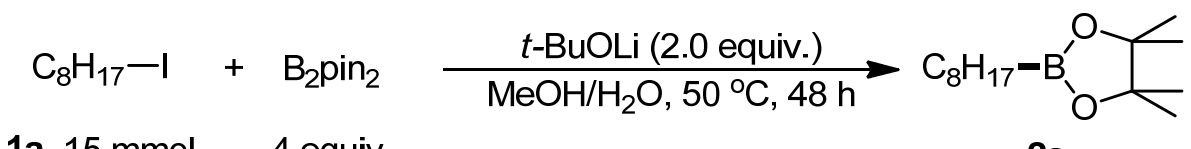

1a, $15 \mathrm{mmol} \quad 4$ equiv.

$2 a$

In a well-dried $100 \mathrm{~mL}$ flask, $1 \mathrm{a}(15 \mathrm{mmol}, 3.60 \mathrm{~g}, 2.71 \mathrm{~mL})$, t-BuOLi $(30 \mathrm{mmol}, 2$ equiv., $2.40 \mathrm{~g})$ and $\mathrm{B}_{2} \mathrm{pin}_{2}(60 \mathrm{mmol}, 4$ equiv., $15.24 \mathrm{~g})$ were dissolved in a mixed solvent of methanol $(30 \mathrm{~mL})$ and water $(0.15 \mathrm{~mL})$. The reaction was allowed to expose into air 
atmosphere. After the flask was closed, the reaction mixture was stirred at $50{ }^{\circ} \mathrm{C}$ for $48 \mathrm{~h}$. Upon cooling to room temperature, the desired product 2a was isolated by column chromatography (silica gel) using PE/EA 50:1 30:1 as eluent. Yield: 2.95 g (82\%), colorless liquid. Then, the unconverted $\mathrm{B}_{2} \mathrm{pin}_{2}$ was recycled using the eluent of PE/EA 10:1 5:1. Recycled $\mathrm{B}_{2}$ pin $_{2}$ amount: $7.57 \mathrm{~g}(50 \%)$.

\subsection{GC-MS data for products measured by GC-FID or NMR}

5
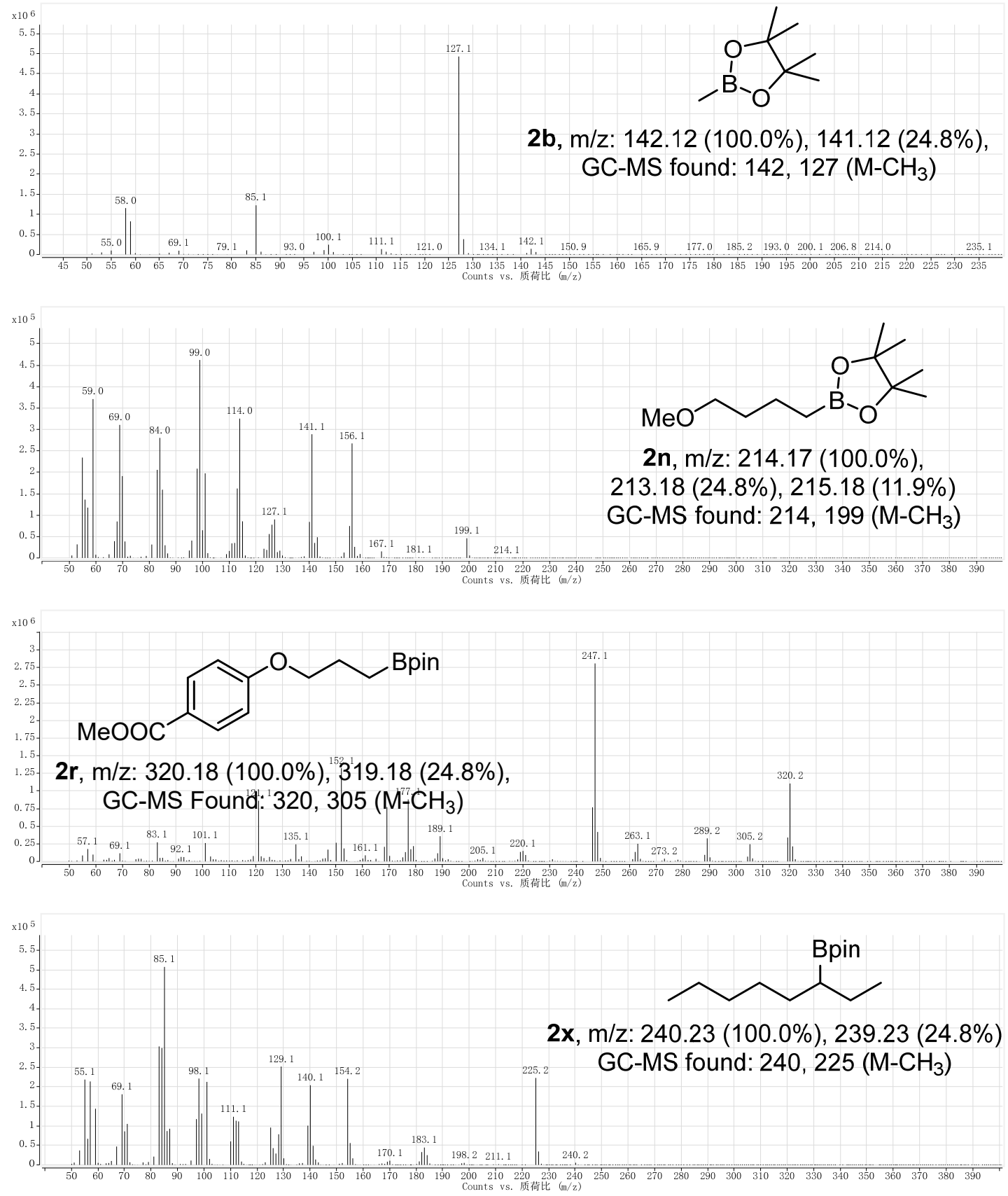


\section{Mechanistic studies}

\subsection{Kinetic experiments}

In this part, we tested the reaction rate in the first 1 hour. The iodide was added in kinetic interval. Each group of experiments ran in parallel.

$$
\mathrm{C}_{8} \mathrm{H}_{17}-\mathrm{I}+\mathrm{B}_{2} \mathrm{pin}_{2} \underset{t-\mathrm{BuOLi}, \mathrm{MeOH} / \mathrm{H}_{2} \mathrm{O}}{50^{\circ} \mathrm{C}, 1 \mathrm{~h}} \mathrm{C}_{8} \mathrm{H}_{17}-\text { Bpin }
$$

1a

General procedure: in a glove box, $\mathbf{1 a}$ (about $0.1 \mathrm{mmol}$ ), $t$-BuOLi and $\mathrm{B}_{2} \mathrm{pin}_{2}$ were dissolved in methanol $(0.85 \mathrm{~mL})$ and water $(10 \mu \mathrm{L})$. After removing the sealed vial from the glove box, the reaction mixture was stirred at $50^{\circ} \mathrm{C}$ for $1 \mathrm{~h}$. Upon cooling to room temperature, decane $(\sim 30 \mathrm{mg})$ was added, the conversion and yield were tested by GC (FID).

\section{A. Influence of "free" $B_{2}$ pin $_{2}$ concentration}

\begin{tabular}{|c|c|c|c|c|c|c|c|}
\hline Exp No. & $\begin{array}{c}\mathrm{C}_{8} \mathrm{H}_{17} \mathrm{I} \\
(\mathrm{mmol})\end{array}$ & $\begin{array}{c}\mathrm{B}_{2} \mathrm{pin}_{2} \\
(\mathrm{mmol})\end{array}$ & $\begin{array}{c}t \text {-BuOLi } \\
(\mathrm{mmol})\end{array}$ & Conv. Sub & Yield & $\begin{array}{c}\text { Conv- } \\
\text { Yield }\end{array}$ & $\begin{array}{c}\text { Yield/(Conv-yi } \\
\text { eld) }\end{array}$ \\
\hline 1 & 0.1 & 0.75 & 0.5 & $30.2 \%$ & $8.5 \%$ & $21.7 \%$ & 0.3917 \\
\hline 2 & 0.1 & 1 & 0.5 & $37.1 \%$ & $13.6 \%$ & $23.5 \%$ & 0.5787 \\
\hline 3 & 0.1 & 1.25 & 0.5 & $55.5 \%$ & $26.8 \%$ & $28.7 \%$ & 0.9338 \\
\hline 4 & 0.1 & 1.5 & 0.5 & $38.5 \%$ & $20.4 \%$ & $18.1 \%$ & 1.1271 \\
\hline
\end{tabular}

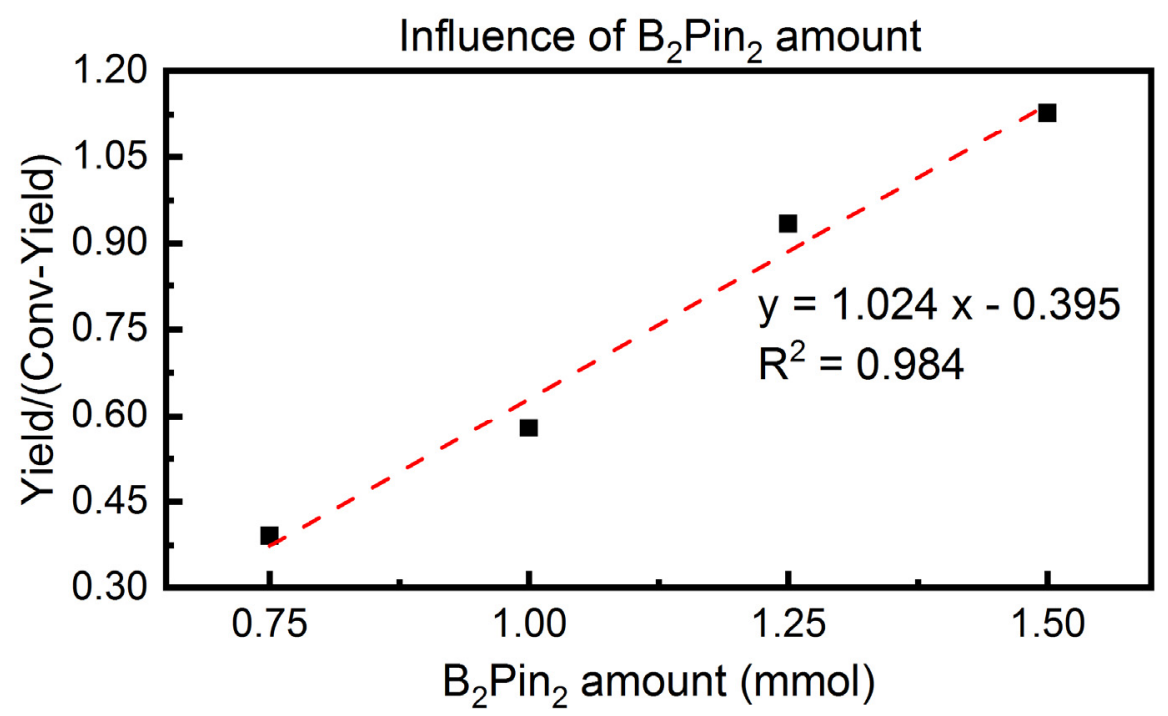


With constant concentration of substrate and base, we found that the ratio of the product and by-products (described by the difference between the conversion of substrate and the yield) showed linear relation with the amount of $B_{2} \operatorname{pin}_{2}\left(R^{2}=0.984\right)$.

\section{B. Influence of base concentration with the same $B_{2}$ pin $_{2}$ amount}

\begin{tabular}{|c|c|c|c|c|c|c|c|}
\hline Exp No. & $\begin{array}{l}\mathrm{C}_{8} \mathrm{H}_{17} \mathrm{I} \\
(\mathrm{mmol})\end{array}$ & $\begin{array}{l}\mathrm{B}_{2} \mathrm{pin}_{2} \\
(\mathrm{mmol})\end{array}$ & $\begin{array}{c}t-\mathrm{BuOLi} \\
(\mathrm{mmol})\end{array}$ & $\begin{array}{c}t-\mathrm{BuOLi} / \\
\mathrm{B}_{2} \operatorname{pin}_{2}\end{array}$ & Conv. Sub & Yield & Yield/Conv \\
\hline 1 & 0.1 & 1.5 & 0 & 0 & 0 & 0 & \\
\hline 2 & 0.1 & 1.5 & 0.25 & 0.167 & $28.3 \%$ & $15.0 \%$ & 0.530 \\
\hline 3 & 0.1 & 1.5 & 0.5 & 0.333 & $27.5 \%$ & $14.9 \%$ & 0.542 \\
\hline 4 & 0.1 & 1.5 & 0.75 & 0.5 & $14.9 \%$ & $12.1 \%$ & $(0.812)$ \\
\hline 5 & 0.1 & 1.5 & 1 & 0.667 & $16.6 \%$ & $10.7 \%$ & 0.645 \\
\hline 6 & 0.1 & 1.5 & 1.25 & 0.833 & $12.8 \%$ & $7.19 \%$ & 0.562 \\
\hline 7 & 0.1 & 1.5 & 1.5 & 1 & $6.16 \%$ & $2.94 \%$ & 0.477 \\
\hline
\end{tabular}

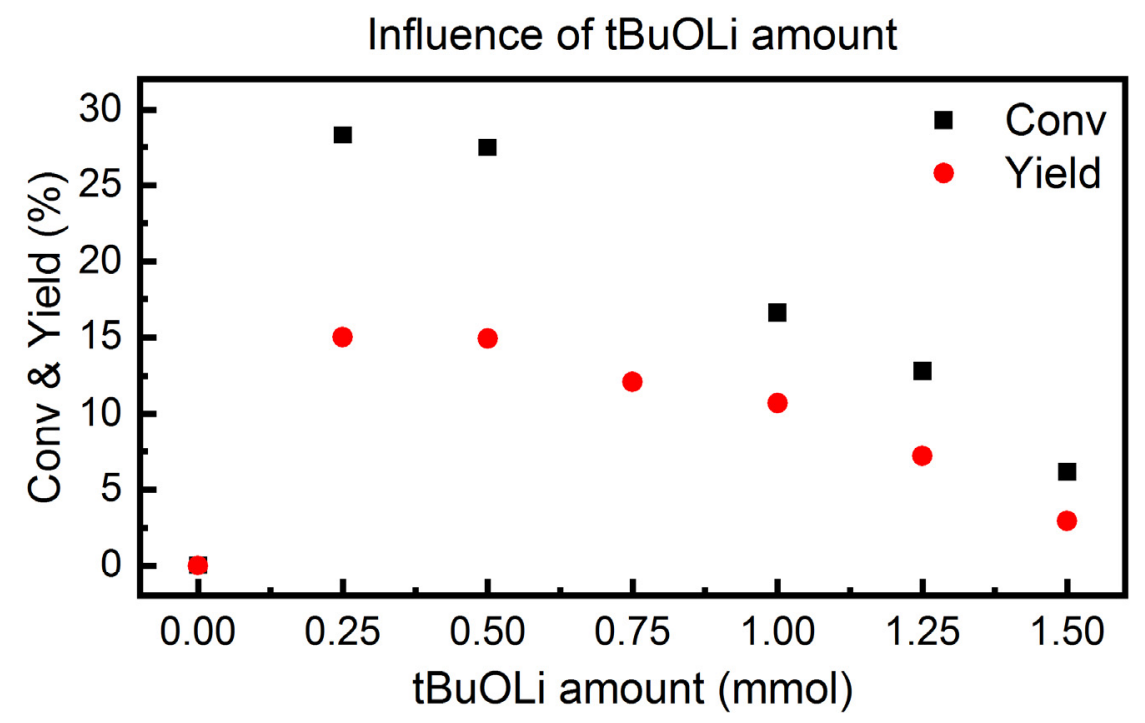

In this group, the $4^{\text {th }}$ case might be a bad point (marked in red). With constant content of substrate and $\mathrm{B}_{2} \mathrm{pin}_{2}$, we changed the amount of base from 0 to $1.5 \mathrm{mmol}$. In 1.0 to $1.5 \mathrm{mmol}$ interval, we found that the conversion and yield both decreased with the increasing of base content (nearly linear, with $\mathrm{R}^{2}=0.977$ for conversion and $\mathrm{R}^{2}=0.997$ for yield), while the yield decreased a little bit faster. However, in 0.25 to $0.5 \mathrm{mmol}$ interval, the conversion and yield were both insensitive with base amount. Finally, the reaction didn't run at all without base.

\section{Influence of substrate concentration}

\begin{tabular}{|c|c|c|c|c|c|c|c|}
\hline & $\begin{array}{c}\mathrm{C}_{8} \mathrm{H}_{17} \mathrm{I} \\
(\mathrm{mmol})\end{array}$ & $\begin{array}{c}\mathrm{B}_{2} \text { pin }_{2} \\
(\mathrm{mmol})\end{array}$ & $\begin{array}{c}t \text {-BuOLi } \\
(\mathrm{mmol})\end{array}$ & Conv.Sub & Yield & $\begin{array}{c}\text { Converted } \\
\text { sub }(\mathrm{mmol})\end{array}$ & $\begin{array}{c}\text { Product } \\
(\mathrm{mmol})\end{array}$ \\
\hline
\end{tabular}




\begin{tabular}{|l|c|c|c|c|c|c|c|}
\hline 1 & 0.05 & 1.5 & 0.5 & $28.4 \%$ & $19.0 \%$ & 0.0142 & 0.0095 \\
\hline 2 & 0.1 & 1.5 & 0.5 & $20.6 \%$ & $15.6 \%$ & 0.0206 & 0.0156 \\
\hline 3 & 0.15 & 1.5 & 0.5 & $19.5 \%$ & $14.6 \%$ & 0.0293 & 0.0219 \\
\hline 4 & 0.2 & 1.5 & 0.5 & $16.7 \%$ & $12.9 \%$ & 0.0334 & 0.0259 \\
\hline
\end{tabular}

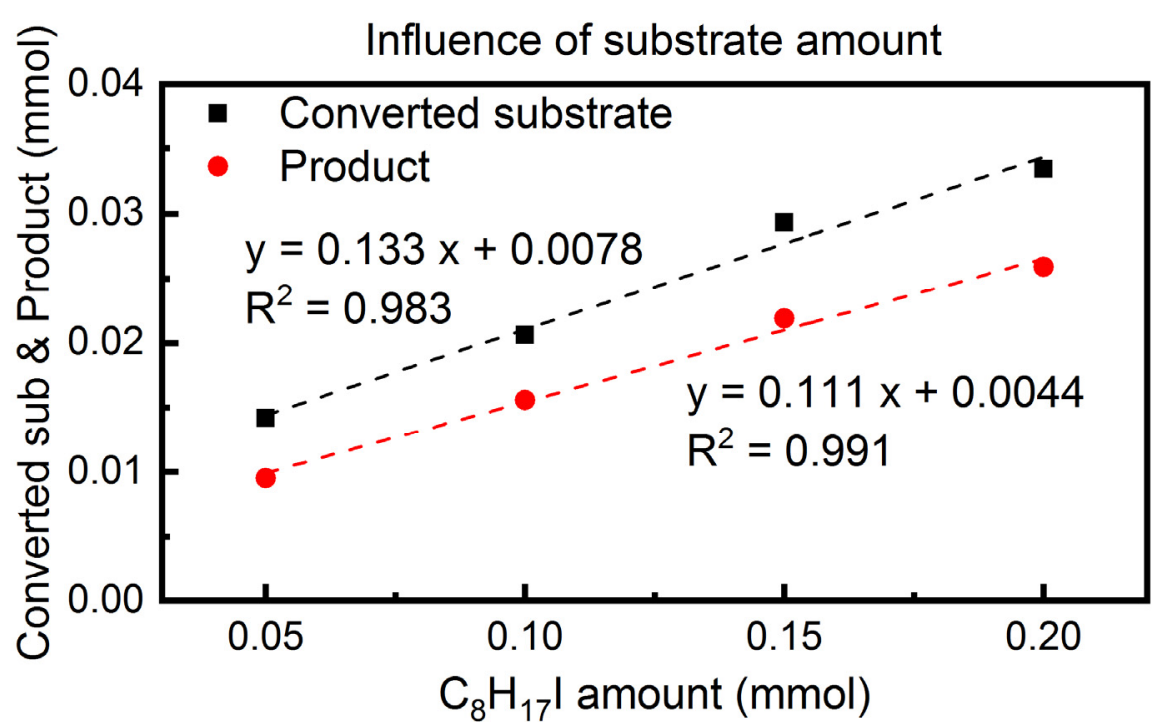

In this group, the kinetic was described by the amount of the converted substrate and the desired product, instead of the conversion and yield due to the different substrate concentration in each case. With the same concentration of $\mathrm{B}_{2} \mathrm{pin}_{2}$ and base, we found that the amount of the converted substrate and the product both showed linear relation with the concentration of substrate (with $\mathrm{R}^{2}$ of 0.983 and 0.991 , respectively), indicating that the conversion of the substrate and the formation of the desired product both mainly through a first-order reaction pathway for the substrate. Small intercepts were found might due to the other uncertain pathways. In addition, the ratio of the slopes for the product and the converted substrate was 0.835 , indicating that with a high enough substrate concentration the yield would approach $83.5 \%$ after the substrate complete conversion. It showed agreement with the yield of 2 a using 3 equiv. of $B_{2} \operatorname{pin}_{2}$ (83\%, using $0.5 \mathrm{mmol}$ of $\mathbf{1 a}$ and 1.5 mmol of $B_{2} \operatorname{pin}_{2}$ in same amount of solvent).

\section{Influence of "adduct" concentration}

\begin{tabular}{|c|c|c|c|c|c|}
\hline Exp No & $\mathrm{C}_{8} \mathrm{H}_{17} \mathrm{I}(\mathrm{mmol})$ & $\mathrm{B}_{2} \mathrm{pin}_{2}(\mathrm{mmol})$ & $t$-BuOLi $(\mathrm{mmol})$ & Conv. Sub & Yield \\
\hline 1 & 0.1 & 0.75 & 0.25 & $21.8 \%$ & $11.5 \%$ \\
\hline 2 & 0.1 & 1 & 0.5 & $20.4 \%$ & $11.0 \%$ \\
\hline 3 & 0.1 & 1.25 & 0.75 & $16.4 \%$ & $8.5 \%$ \\
\hline 4 & 0.1 & 1.5 & 1 & $14.0 \%$ & $6.4 \%$ \\
\hline
\end{tabular}




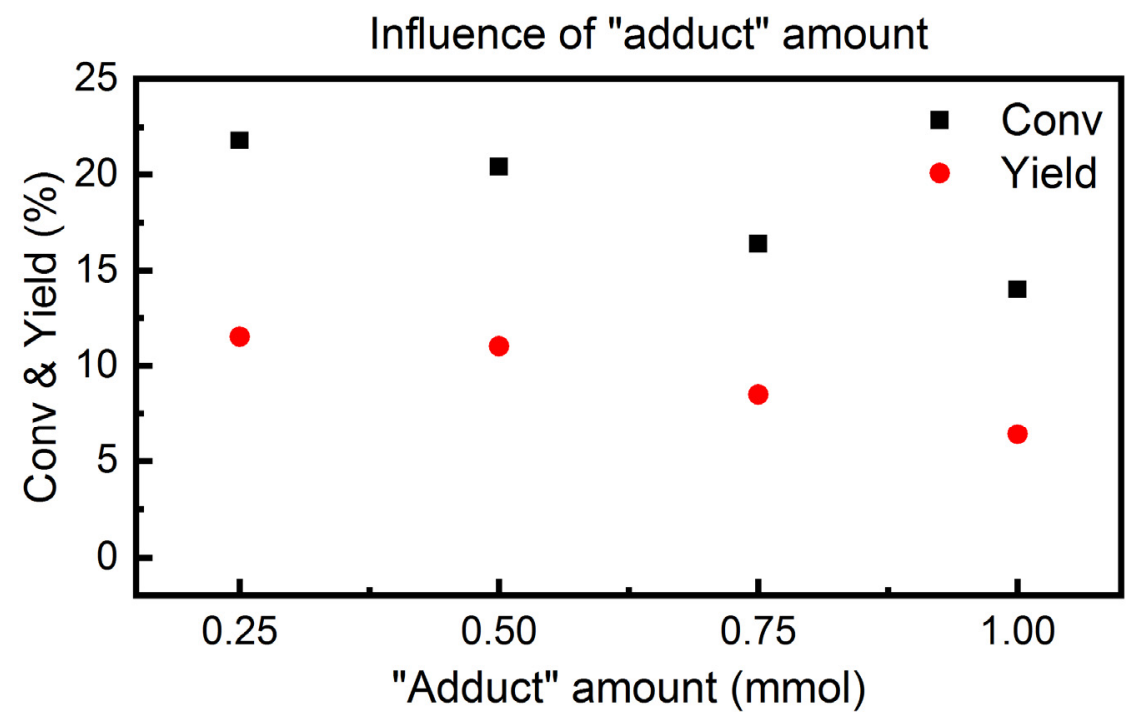

The substrate concentration and the difference between $\mathrm{B}_{2} \mathrm{pin}_{2}$ and $t$ - $\mathrm{BuOLi}$ were fixed, i.e., each case had the same "free" $B_{2} \operatorname{pin}_{2}$ concentration and different "adduct" concentration. The conversion and yield were similar with 0.25 to $0.50 \mathrm{mmol}$ of "adduct", but they were slowly decreased with higher "adduct" concentration. Because for the first two cases clear solutions were given but for the latter two cases precipitates were formed, we suggested that the reaction rate was independent with the concentration of "adduct" while the decreasing yields of the latter two cases was due to the inhibition of the precipitate under high reagent concentration.

We can summarize the above four groups of experiments as follows. First of all, the reaction is mainly a first-order process for the substrate. Moreover, the key species to form the borylation product is the "free" $\mathrm{B}_{2} \mathrm{pin}_{2}$, instead of the "adduct". Thus we suggest that since the alkyl radical is formed, it interacts with the "free" $\mathrm{B}_{2} \mathrm{pin}_{2}$, and somehow forms the desired product. 


\subsection{Metal residue experiments and reaction in the absence of light}

The ICP analysis for transition metal residues was taken by Tsinghua University Analysis

Center. We compared the transition metal residues of the chemicals provided from ENERGY

CHEMICAL and SIGMA-ALDRICH.

Table S4 ICP analysis for $\mathrm{B}_{2}$ pin $_{2}$ and $t$-BuOLi (in ppm)

\begin{tabular}{|c|c|c|c|c|c|c|}
\hline $\begin{array}{c}\mathrm{B}_{2} \text { pin }_{2} \\
\text { TM residue }\end{array}$ & $\begin{array}{c}57 \mathrm{Fe} \\
(\mathrm{KED})\end{array}$ & $\begin{array}{c}55 \mathrm{Mn} \\
(\mathrm{KED})\end{array}$ & $\begin{array}{c}60 \mathrm{Ni} \\
(\mathrm{KED})\end{array}$ & $\begin{array}{c}63 \mathrm{Cu} \\
(\mathrm{KED})\end{array}$ & $\begin{array}{c}66 \mathrm{Zn} \\
(\mathrm{KED})\end{array}$ & $\begin{array}{c}105 \mathrm{Pd} \\
(\mathrm{KED})\end{array}$ \\
\hline ENERGY & 1.77 & 0.06 & 0.09 & 0.16 & 3.13 & 0.18 \\
\hline SIGMA & 3.74 & 0.09 & 0.46 & 1.09 & 1.51 & 0.06 \\
\hline
\end{tabular}

\begin{tabular}{|c|c|c|c|c|c|c|}
\hline $\begin{array}{c}t-\mathrm{BuOLi} \\
\text { TM residue }\end{array}$ & $\begin{array}{c}63 \mathrm{Cu} \\
(\mathrm{KED})\end{array}$ & $\begin{array}{c}66 \mathrm{Zn} \\
(\mathrm{KED})\end{array}$ & $\begin{array}{c}57 \mathrm{Fe} \\
(\mathrm{KED})\end{array}$ & $\begin{array}{c}55 \mathrm{Mn} \\
(\mathrm{KED})\end{array}$ & $\begin{array}{c}60 \mathrm{Ni} \\
(\mathrm{KED})\end{array}$ & $\begin{array}{c}105 \mathrm{Pd} \\
(\mathrm{KED})\end{array}$ \\
\hline ENERGY & 2.63 & 22.90 & 67.39 & 5.18 & 1.07 & 1.30 \\
\hline SIGMA & 0.32 & 0.84 & 3.56 & 0.06 & 0.16 & 0.13 \\
\hline
\end{tabular}

These results showed that the chemicals from SIGMA-ALDRICH have significantly lower TM residues.

Subsequently, we compared the standard reaction using the chemicals from ENERGY

CHEMICAL and SIGMA-ALDRICH.

Table S5. Control experiments using different chemical sources

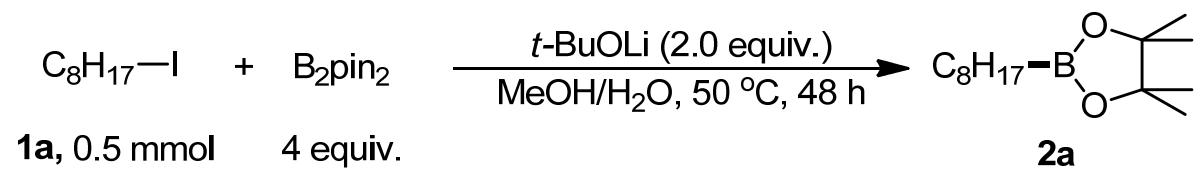

\begin{tabular}{|l|c|c|}
\hline Source of reagents & Conv. of Substrate & Yield \\
\hline ENERGY CHEMICAL & $98.5 \%$ & $86.7 \%$ \\
\hline SIGMA-ALDRICH & $100 \%$ & $79.2 \%$ \\
\hline
\end{tabular}

Accordingly, the yields were close.

Furthermore, we have performed these reactions with additional transition metal salts.

Those reactions were continued for $4 \mathrm{~h}$. The results are depicted in Table S6.

Table S6. Reaction with additional TM salts 


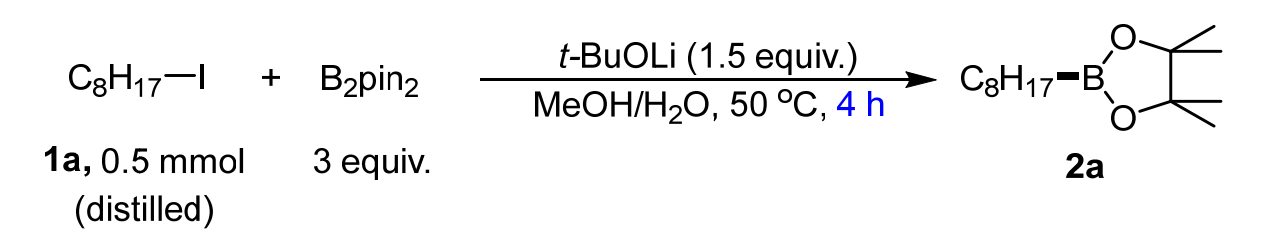

\begin{tabular}{|l|l|l|l|l|}
\hline Exp. No & Additive & Conv. of 1a & Conv. of $\mathrm{B}_{2} \mathrm{pin}_{2}$ & Yield of 2a \\
\hline 1 & None & $73.8 \%$ & $66.9 \%$ & $52.3 \%$ \\
\hline 2 & $\mathrm{CuCl}(2.5 \mathrm{~mol} \%)$ & $97.9 \%$ & $73.4 \%$ & $85.8 \%$ \\
\hline 3 & $\mathrm{CuCl}(5 \mathrm{~mol} \%)$ & $100 \%$ & $77.0 \%$ & $79.9 \%$ \\
\hline 4 & $\mathrm{MnBr}_{2} \cdot 4 \mathrm{H}_{2} \mathrm{O}(2.5 \mathrm{~mol} \%)$ & $73.9 \%$ & $71.5 \%$ & $51.7 \%$ \\
\hline 5 & $\mathrm{MnBr}_{2} \cdot 4 \mathrm{H}_{2} \mathrm{O}(5 \mathrm{~mol} \%)$ & $73.4 \%$ & $71.4 \%$ & $51.8 \%$ \\
\hline 6 & $\mathrm{NiCl}_{2} \cdot 6 \mathrm{H}_{2} \mathrm{O}(2.5 \mathrm{~mol} \%)$ & $100 \%$ & $82.0 \%$ & $56.9 \%$ \\
\hline 7 & $\mathrm{NiCl}_{2} \cdot 6 \mathrm{H}_{2} \mathrm{O}(5 \mathrm{~mol} \%)$ & $100 \%$ & $78.6 \%$ & $52.9 \%$ \\
\hline 8 & ${\mathrm{Zn}\left(\mathrm{NO}_{3}\right)_{2} \cdot 6 \mathrm{H}_{2} \mathrm{O}(2.5 \mathrm{~mol} \%)}_{100 \%}$ & $76.9 \%$ & $37.9 \%$ \\
\hline 9 & $\mathrm{Zn}\left(\mathrm{NO}_{3}\right)_{2} \cdot 6 \mathrm{H}_{2} \mathrm{O}(5 \mathrm{~mol} \%)$ & $100 \%$ & $81.4 \%$ & $36.9 \%$ \\
\hline
\end{tabular}

These results indicate that many transition-metal salts, such as $\mathrm{Mn}(\mathrm{II}), \mathrm{Ni}$ (II) and $\mathrm{Zn}$ (II) show no catalytic ability on the desired borylation reaction despite the fact that $\mathrm{Cu}$ salts are catalytically active in catalytic amount $(2.5 \% \sim 5 \%)$. This is consistent with other $\mathrm{Cu}$-catalyzed borylation of alkyl halides works published in the past decade. ${ }^{31-32}$ However, in our system the amount of $\mathrm{Cu}$ residue was only several $\mathrm{ppm}$. To further examine whether the $\mathrm{Cu}$ residue in the reagents play an important role in this transformation, we compared the yield of the borylation product formed in $1 \mathrm{~h}$ using distilled $\mathrm{n}$-iodooctane and chemicals from different source (Table S7).

Table S7. Effect of Cu residue with different concentration level

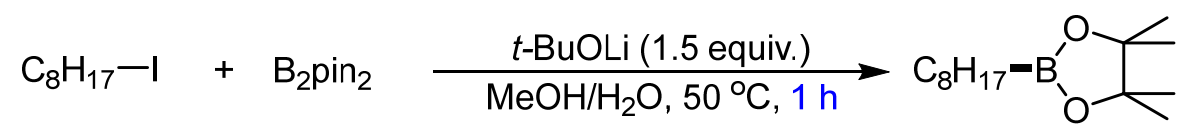

$$
\begin{aligned}
& \text { 1a, } 0.5 \mathrm{mmol} \quad 3 \text { equiv. 2a } \\
& \text { (distilled) }
\end{aligned}
$$

\begin{tabular}{|c|c|c|c|c|c|c|}
\hline $\begin{array}{l}\text { Exp. } \\
\text { No }\end{array}$ & $\mathrm{B}_{2} \operatorname{pin}_{2}$ & $t-\mathrm{BuOLi}$ & $\begin{array}{l}\mathrm{Cu} \\
\text { equivalency }\end{array}$ & $\begin{array}{l}\text { Conv. of } \\
\text { 1a }\end{array}$ & $\begin{array}{l}\text { Conv. of } \\
\mathrm{B}_{2} \mathrm{pin}_{2}\end{array}$ & $\begin{array}{l}\text { Yield of } \\
\mathbf{2 a}\end{array}$ \\
\hline
\end{tabular}




\begin{tabular}{|l|l|l|l|l|l|l|}
\hline 1 & ENERGY & SIGMA & $2.5 \mathrm{e}-6$ & $26.1 \%$ & $67.5 \%$ & $12.8 \%$ \\
\hline 2 & SIGMA & ENERGY & $18.0 \mathrm{e}-6$ & $19.1 \%$ & $67.6 \%$ & $6.4 \%$ \\
\hline 3 & ENERGY & ENERGY & $6.9 \mathrm{e}-6$ & $20.2 \%$ & $69.5 \%$ & $10.5 \%$ \\
\hline 4 & SIGMA & SIGMA & $13.7 \mathrm{e}-6$ & $17.7 \%$ & $68.3 \%$ & $6.7 \%$ \\
\hline
\end{tabular}

These results show that the yields are not relevant to the $\mathrm{Cu}$ residue concentration.

In addition, we designed a reaction in the absence of light to verify whether our reaction is photocatalytic. The standard reaction was run with packing the whole vial by aluminum foil.

Table S8. Reaction in the absence of light.

\begin{tabular}{|c|c|c|c|}
\hline $\begin{array}{l}\mathrm{C}_{8} \mathrm{H}_{17}-\mathrm{I}+ \\
1 \mathrm{a}, 0.5 \mathrm{mmol}\end{array}$ & $\begin{array}{l}\mathrm{B}_{2} \mathrm{pin}_{2} \\
4 \text { equiv. }\end{array}$ & $\begin{array}{r}t \text {-BuOLi }(2.0 \mathrm{e} \\
\mathrm{MeOH} / \mathrm{H}_{2} \mathrm{O}, 50 \\
\text { in the absence }\end{array}$ & $\mathrm{H}$ \\
\hline Condition & & Conv. of Substrate & Yield \\
\hline Non-packed (standard) & & $98.5 \%$ & $86.7 \%$ \\
\hline Aluminum foil packed & & $96.7 \%$ & $85.4 \%$ \\
\hline
\end{tabular}

The yield of the reaction in the absence of light is closed to the standard reaction. Thus we suggested that our reaction is non-photocatalytic. 


\subsection{Other mechanistic experiments}

\section{Reaction with TEMPO}

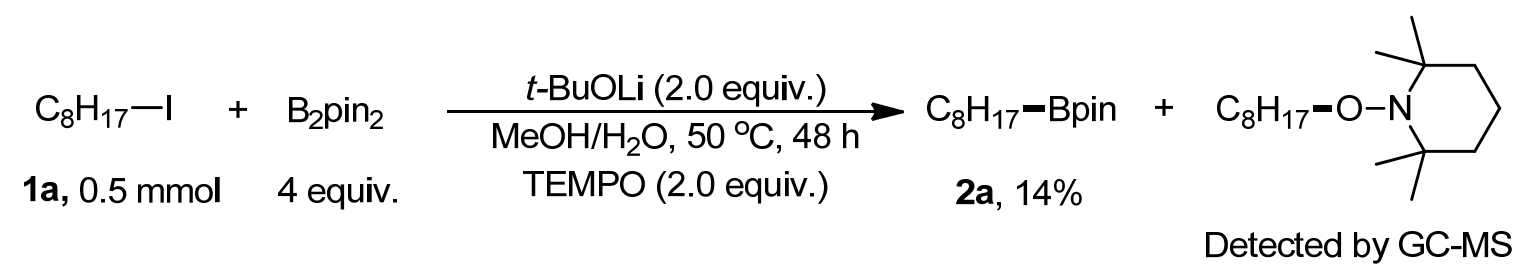

In a glove box, $1 \mathbf{a}(0.5 \mathrm{mmol}, 120 \mathrm{mg}, 91 \mu \mathrm{L}), t-\mathrm{BuOLi}(1.0 \mathrm{mmol}, 80.1 \mathrm{mg}), \mathrm{B}_{2} \operatorname{pin}_{2}(2.0$ $\mathrm{mmol}, 508 \mathrm{mg})$ and TEMPO $(1.0 \mathrm{mmol}, 156 \mathrm{mg})$ were dissolved in methanol $(0.85 \mathrm{~mL})$ and water $(10 \mu \mathrm{L})$. After removing the sealed vial from the glove box, the reaction mixture was stirred at $50^{\circ} \mathrm{C}$ for $48 \mathrm{~h}$. Upon cooling to room temperature, decane $(\sim 30 \mathrm{mg})$ was added, the conversion and yield were tested by GC (FID), and the reaction mixture was measured by GC-MS.

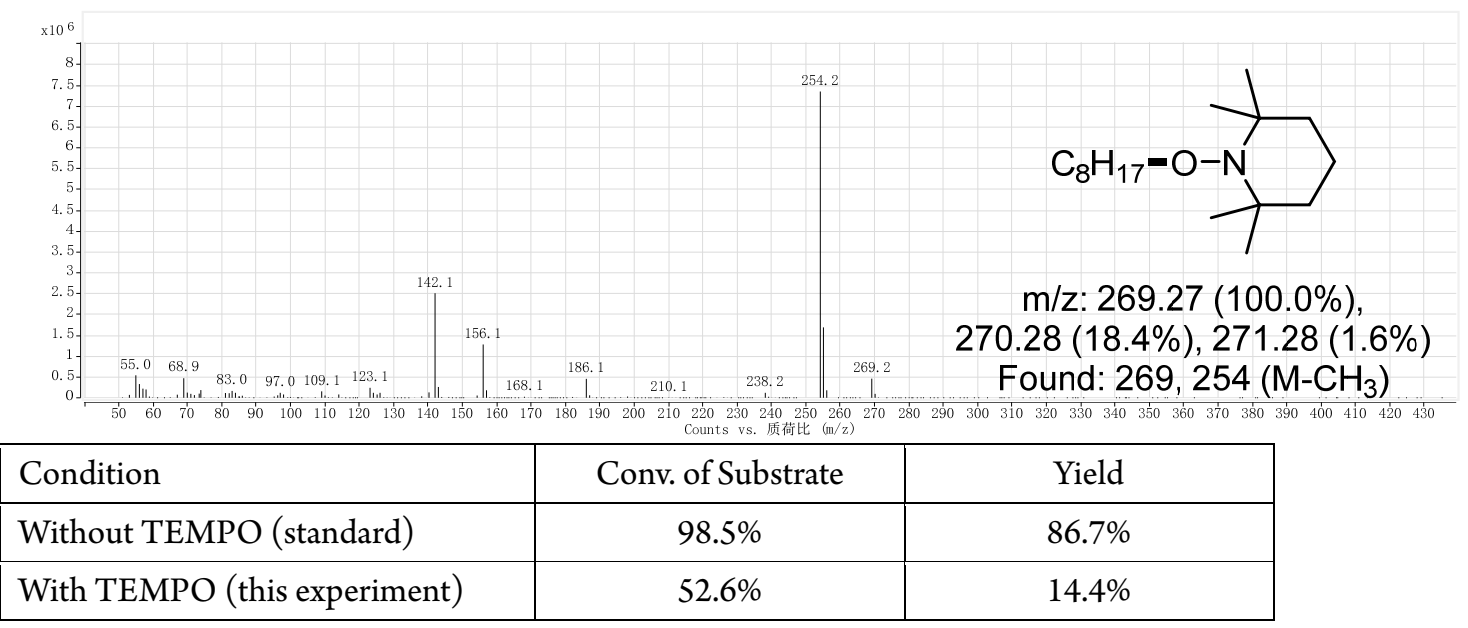

\section{“Clock” reaction}

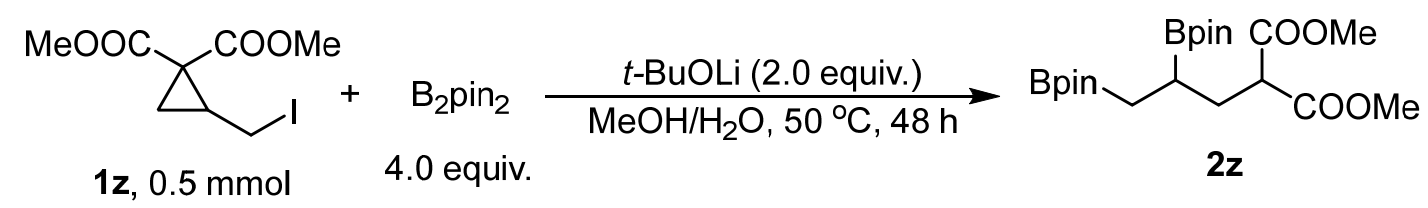

In a glove box, $\mathbf{1 z}(0.5 \mathrm{mmol}, 149 \mathrm{mg}), t-\mathrm{BuOLi}(1.0 \mathrm{mmol}, 80.1 \mathrm{mg})$ and $\mathrm{B}_{2} \mathrm{pin}_{2}(2 \mathrm{mmol}$, $508 \mathrm{mg})$ were dissolved in methanol $(0.85 \mathrm{~mL})$ and water $(10 \mu \mathrm{L})$. After removing the sealed vial from the glove box, the reaction mixture was stirred at $50^{\circ} \mathrm{C}$ for $48 \mathrm{~h}$. Upon cooling to room temperature, silica gel was added, the solvent was removed and the product 
$\mathbf{2 z}$ was purified by column chromatography using PE/EA 10:1 5:1 as eluent $(\mathrm{Rf}=0.5$ using PE/EA 3:1). Yield: $177.4 \mathrm{mg}$ (83\%), colorless liquid. ${ }^{1} \mathrm{H} \mathrm{NMR}\left(400 \mathrm{MHz}, \mathrm{CDCl}_{3}\right) \delta$ $3.72(\mathrm{~s}, 6 \mathrm{H}), 3.60(\mathrm{dd}, J=8.3,6.8 \mathrm{~Hz}, 1 \mathrm{H}), 2.11-2.03(\mathrm{~m}, 1 \mathrm{H}), 1.98-1.86(\mathrm{~m}, 1 \mathrm{H}), 1.23$ (s, 12H), $1.23(\mathrm{~s}, 12 \mathrm{H}), 1.15-1.04(\mathrm{~m}, 1 \mathrm{H}), 0.86(\mathrm{~d}, J=7.3 \mathrm{~Hz}, 2 \mathrm{H}) .{ }^{13} \mathrm{C}$ NMR $(101 \mathrm{MHz}$, $\left.\mathrm{CDCl}_{3}\right) \delta 170.31,170.12,83.12,83.01,52.33,52.31,50.84,32.25,24.83,24.70$. IR: $v=2978$, 2931, 2160, 2033, 1976, 1754, 1735, 1435, 1407, 1371, 1314, 1268, 1239, 1213, 1139, 1109 , $1026,967,923,882,847,706,671,578,522,458 \mathrm{~cm}^{-1} .{ }^{11} \mathrm{~B} \mathrm{NMR}\left(160 \mathrm{MHz}, \mathrm{CDCl}_{3}\right) \delta 33.85$. HRMS: Calcd. $\mathrm{C}_{20} \mathrm{H}_{37} \mathrm{~B}_{2} \mathrm{O}_{8}{ }^{+}[\mathrm{M}+\mathrm{H}]^{+}$: 427.2669. Found: 427.2686. Calcd. $\mathrm{C}_{20} \mathrm{H}_{40} \mathrm{~B}_{2} \mathrm{NO}_{8}{ }^{+}$ $\left[\mathrm{M}+\mathrm{NH}_{4}\right]^{+}:$444.2934. Found: 444.2931.

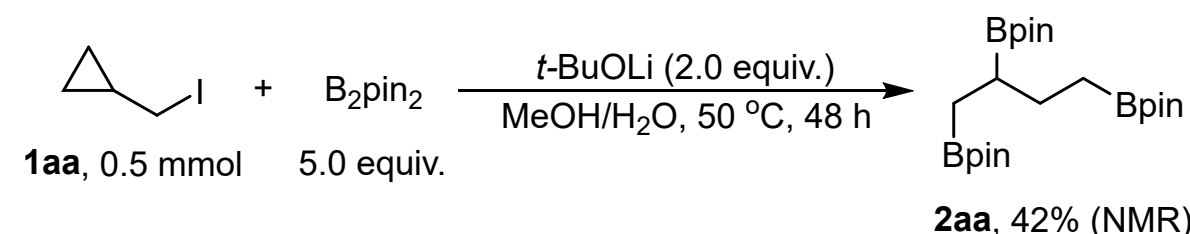

In a glove box, (iodomethyl)cyclopropane 1 aa $(0.5 \mathrm{mmol}, 91 \mathrm{mg}), t-\mathrm{BuOLi}(1.0 \mathrm{mmol}, 80.1$ $\mathrm{mg})$ and $\mathrm{B}_{2} \operatorname{pin}_{2}(2.5 \mathrm{mmol}, 635 \mathrm{mg})$ were dissolved in methanol $(0.85 \mathrm{~mL})$ and water $(10$ $\mu \mathrm{L})$. After removing the sealed vial from the glove box, the reaction mixture was stirred at $50{ }^{\circ} \mathrm{C}$ for $48 \mathrm{~h}$. Upon cooling to room temperature, the reaction mixture was filtered by a small silica column (using PE/EA 3:1 as eluent). After the solvent was removed under vacuum, $\mathrm{C}_{2} \mathrm{H}_{2} \mathrm{Cl}_{4}(54.8 \mathrm{mg})$ was added and the yield of compound $2 \mathrm{aa}$ was tested by ${ }^{1} \mathrm{H}$ NMR (600 MHz, using $\mathrm{CDCl}_{3}$ as solvent) according to the ratio of the area of the signals around $\delta 1.23\left(36 \mathrm{H}\right.$, three Bpin groups) with the signal of $\mathrm{C}_{2} \mathrm{H}_{2} \mathrm{Cl}_{4}(65.9 \mathrm{mg}$ added, signal in

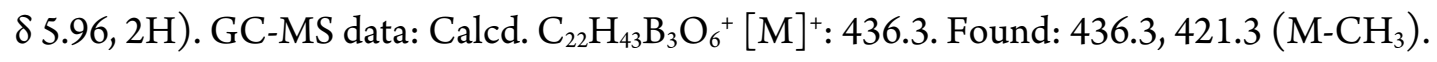
(Can't separate with $B_{2} \operatorname{pin}_{2}$ as the polarity closed to $B_{2} \operatorname{pin}_{2}, \mathrm{Rf}=0.4$ using PE/EA 10:1).

Data of standard sample: ${ }^{1} \mathrm{H}$ NMR $\left(400 \mathrm{MHz}, \mathrm{CDCl}_{3}\right) \delta 1.61-1.49(\mathrm{~m}, 1 \mathrm{H}), 1.46-1.40$ $(\mathrm{m}, 1 \mathrm{H}), 1.21(\mathrm{~s}, 12 \mathrm{H}), 1.20(\mathrm{~s}, 24 \mathrm{H}), 1.12-1.02(\mathrm{~m}, 1 \mathrm{H}), 0.89-0.68(\mathrm{~m}, 4 \mathrm{H})$ according to the literature data. ${ }^{25}$

GC-MS data 

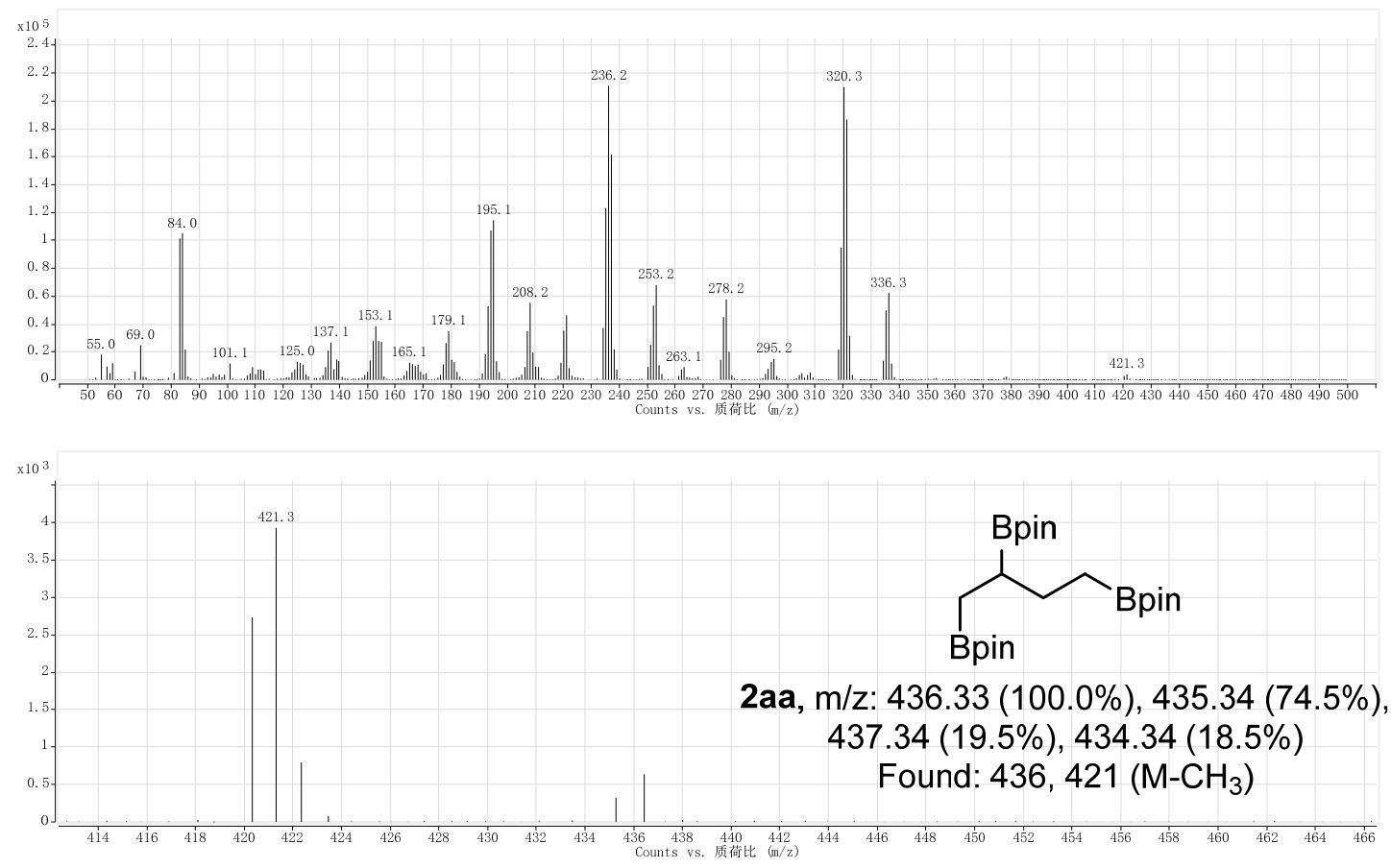

\section{Deuteration reaction and DFT calculations}

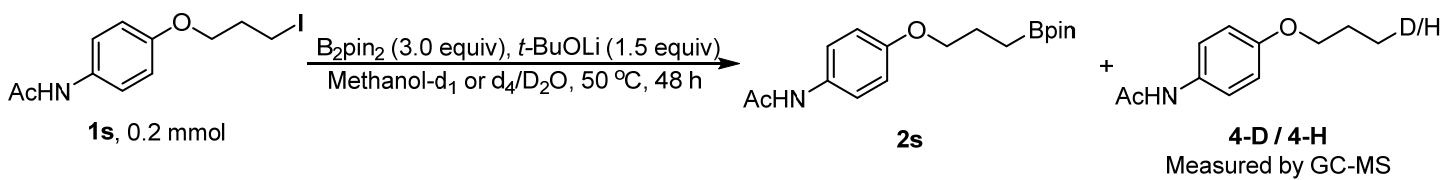

In a glove box, $1 \mathrm{~s}(0.2 \mathrm{mmol}, 64 \mathrm{mg}), t-\mathrm{BuOLi}(0.3 \mathrm{mmol}, 24.0 \mathrm{mg})$ and $\mathrm{B}_{2} \operatorname{pin}_{2}(0.6 \mathrm{mmol}$, $152 \mathrm{mg}$ ) were dissolved in methanol- $\mathrm{d}_{1}$ or methanol- $\mathrm{d}_{4}(1.2 \mathrm{~mL})$ and $\mathrm{D}_{2} \mathrm{O}(12 \mu \mathrm{L})$. After remove the tight vial from the glove box, the reaction mixture was stirred at $50{ }^{\circ} \mathrm{C}$ for $48 \mathrm{~h}$. Upon cooling to room temperature, the reaction mixture was filtered by a small silica column (using EtOAc as eluent) and analyzed by GC-MS.

Case using methanol- $\mathrm{d}_{1}$ as solvent: a mixture of 4-D and 4-H was found.

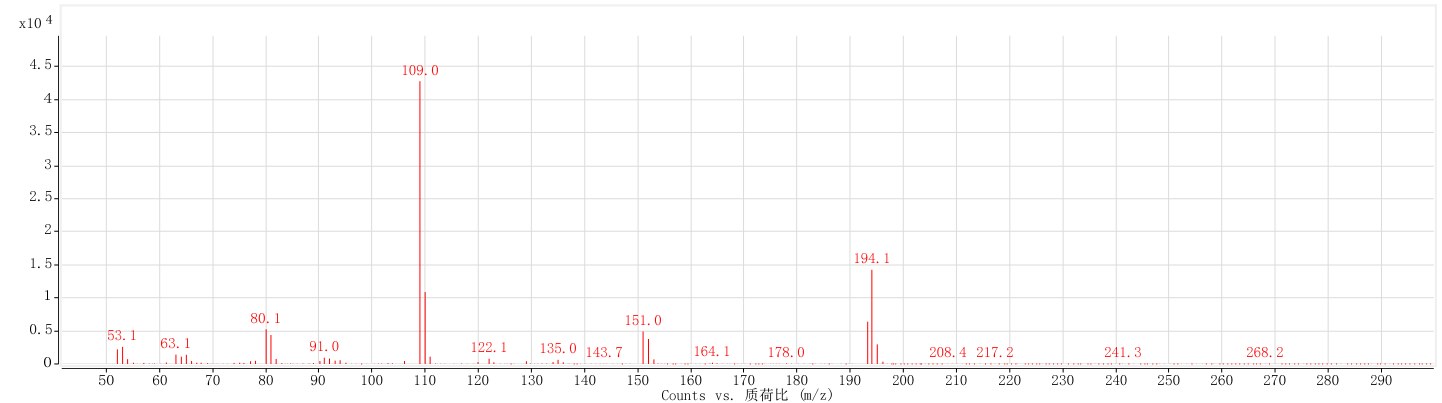




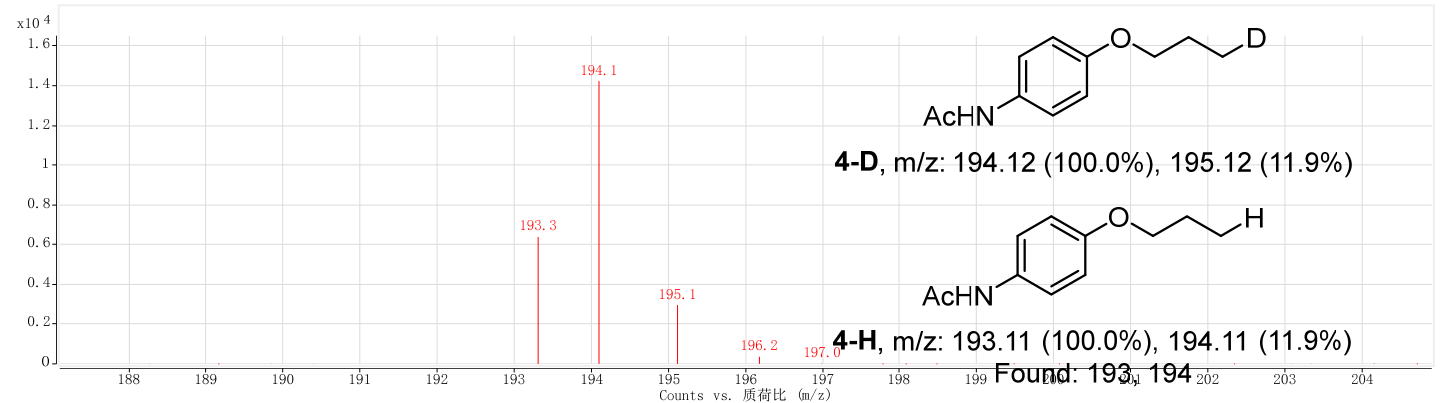

Case using methanol- $\mathrm{d}_{4}$ as solvent: Only 4-D was found.
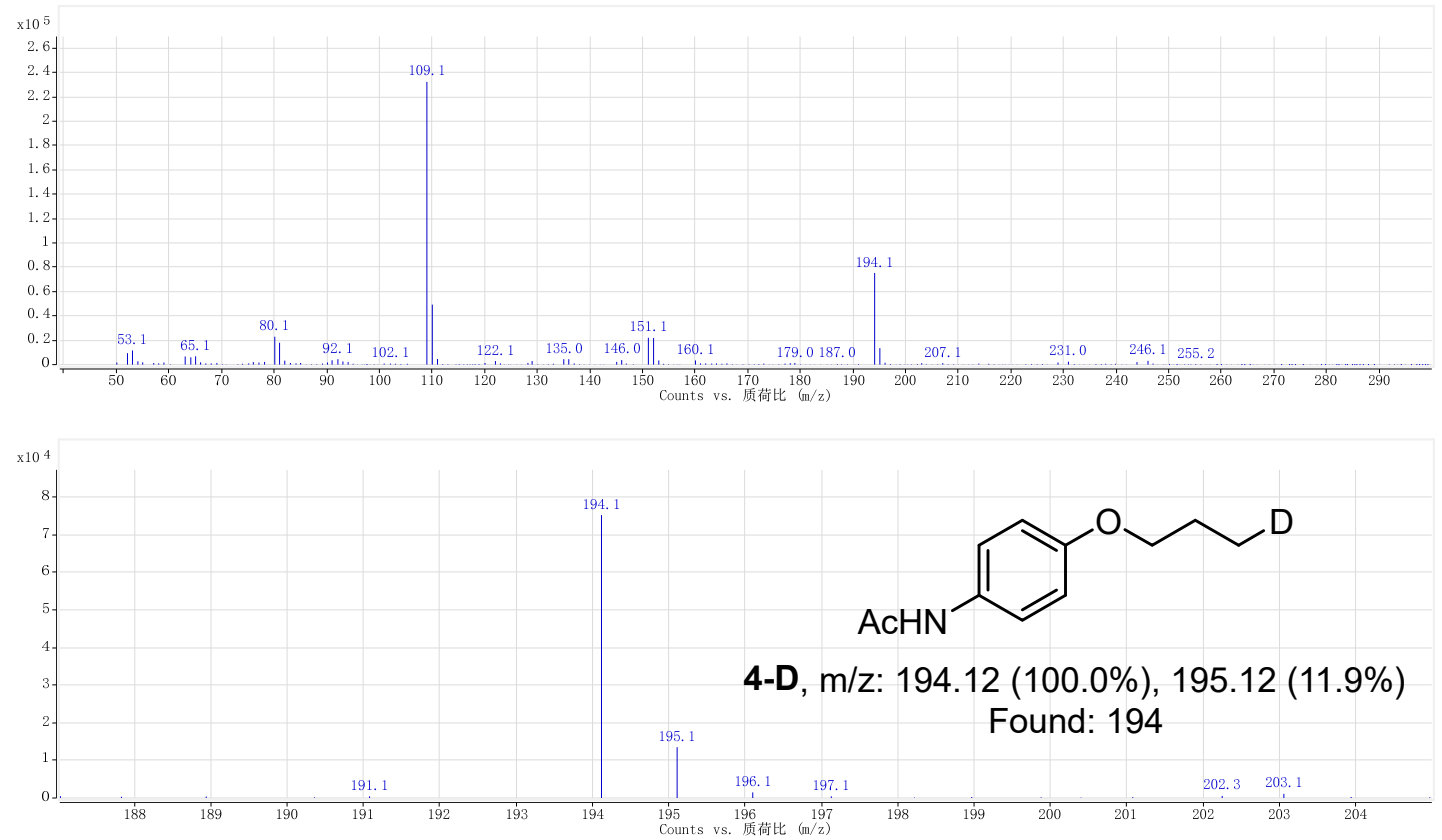

According to the result using methanol- $d_{4}$, only deuterated by-product was found, indicating that the by-product was mainly obtained from the solvent. Then, according to the result using methanol- $d_{1}\left(\mathrm{CH}_{3} \mathrm{OD}\right)$, a mixture of hydrogenated and deuterated by-product was found, thus ignored the procedure from alkyl anion which could only form deuterated by-product in methanol- $d_{1}$.

To further support the radical pathway, we conducted a DFT calculation for the hydrogenation procedure of alkyl radical and methanol. There're two possible pathways, i.e. reaction with the proton atoms of $\mathrm{CH}_{3} \mathrm{OH}$ or $\mathrm{CH}_{3} \mathrm{OH}$. In methanol- $d_{1}$, pathway (a) and (b) will obtain hydrogenated and deuterated by-product, respectively.
$\mathrm{R} \cdot+\mathrm{CH}_{3} \mathrm{OH} \longrightarrow \mathrm{RH}+\cdot \mathrm{CH}_{2} \mathrm{OH}$
$\mathrm{R} \cdot+\mathrm{CH}_{3} \mathrm{OH} \longrightarrow \mathrm{RH}+\cdot \mathrm{OCH}_{3}$ 
For primary and secondary alkyl radicals, ${ }^{n} \mathrm{C}_{8} \mathrm{H}_{17} \bullet$ and ${ }^{i} \mathrm{Pr} \bullet$ were chosen as examples. As shown in Figure S1, although pathway (a) is more thermodynamic favorable, as the significantly lower concentration of $\mathrm{RH}$ and radicals comparing with the solvent methanol, pathway (b) is also feasible, which even has lower activation energy. Thus the hydrogenation procedure would through a mixed pathway of (a) and (b), which showed agreement with our experiment using methanol- $d_{1}$. These experiments and calculation further supported the formation of alkyl radical, instead of alkyl anion.

Figure S1. DFT calculation for hydrogenation procedure of alkyl radicals

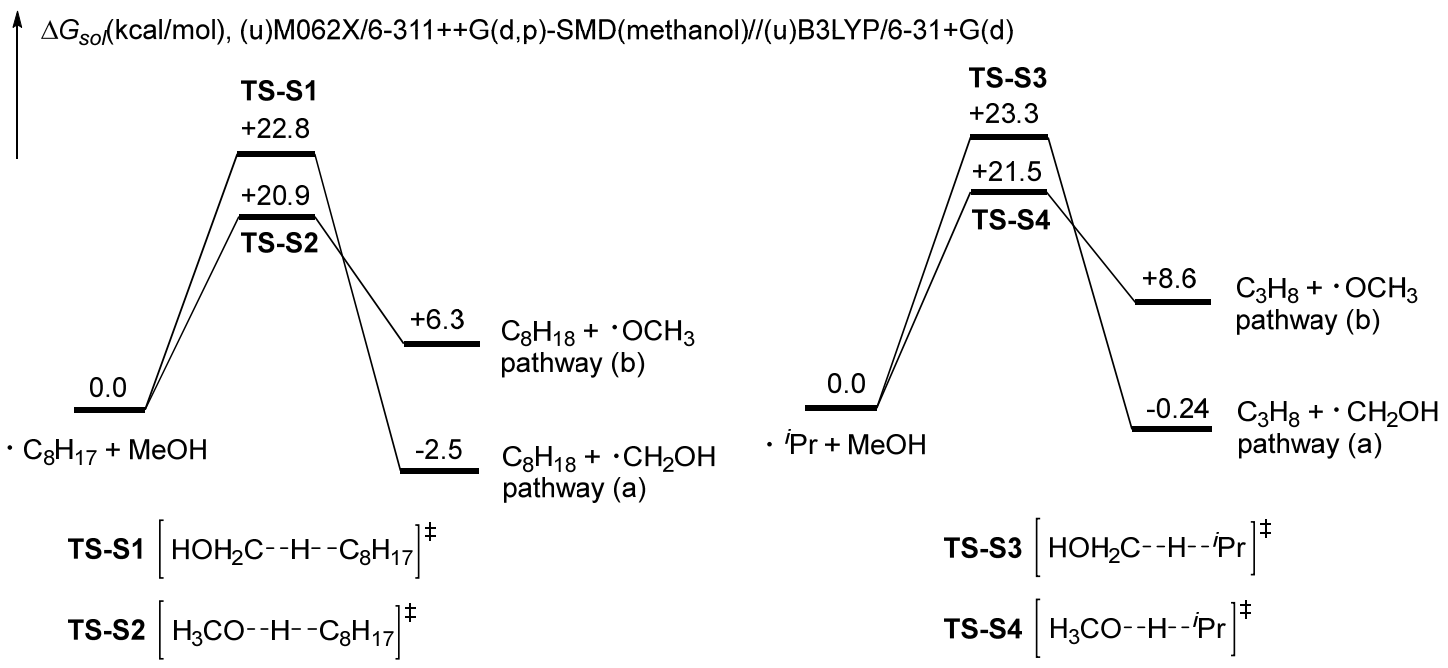

In addition, comparing with the borylation procedure, the hydrogenation procedure has higher activation energy ( $20.9 \mathrm{vs} 15.1 \mathrm{kCal} / \mathrm{mol})$, thus the borylation procedure was competitive. However, firstly, the impact of radical and solvent doesn't need to overcome the solvation, thus the hydrogenation reaction has remarkable higher pre-exponential factor A comparing with the borylation procedure. Secondly, as the solvent, methanol has very high concentration comparing with $\mathrm{B}_{2} \mathrm{pin}_{2}$. Thus the hydrogenation reaction could also have certain competitiveness, and forming the hydrogenated by-products. Therefore a high $\mathrm{B}_{2} \mathrm{pin}_{2}$ concentration is beneficial for the formation of the borylation product. 


\section{EPR experiments and data}

For each case, in a $3 \mathrm{~mL}$ glassy flask, $\mathbf{1 a}-\mathbf{F}_{\mathbf{1 7}}$ (if necessary, $273 \mathrm{mg}, 132 \mu \mathrm{l}, 0.5 \mathrm{mmol}, 1.0$ equiv.) or $1 \mathrm{a}$ (if necessary, $120 \mathrm{mg}, 91 \mu \mathrm{l}, 0.5 \mathrm{mmol}, 1.0$ equiv.), $\mathrm{B}_{2} \operatorname{pin}_{2}$ (if necessary, $508 \mathrm{mg}$, $2.0 \mathrm{mmol}, 4.0$ equiv.), $t$-BuOLi (if necessary, $80 \mathrm{mg}, 1.0 \mathrm{mmol}, 2.0$ equiv.) and DMPO (5.0 $\mu \mathrm{l}, 0.05 \mathrm{mmol}, 0.1$ equiv.) were dissolved in $\mathrm{MeOH}(2.5 \mathrm{~mL})$, and the flask was closed. After stirred at $50{ }^{\circ} \mathrm{C}$ (using a water bath) for $10 \mathrm{~min}$, small amount of the reaction mixture was encased into a capillary tube (diameter $1.0 \mathrm{~mm}$ ) and measured the EPR signal on a Bruker A 200 EPR spectrometer at room temperature. Each case was measured for 4 scans, and each scan was measured for $20 \mathrm{~s}$. The magnetic field scanning region was centered by $g=2$ with $100 \mathrm{G}$ (or $10 \mathrm{mT}$ ) width (about 3462 to $3562 \mathrm{G}$ or 346.2 to $356.2 \mathrm{mT}$ ) and contained 1024

points. The EPR spectra were simulated using the EasySpin-5.2.14 running in Matlab (R2017a) and carefully compared with literature data. ${ }^{33}$ 


\subsection{EPR profiles data}

In these figures, blue lines are experiment data and red lines are simulation data.

\section{Background: only DMPO.}

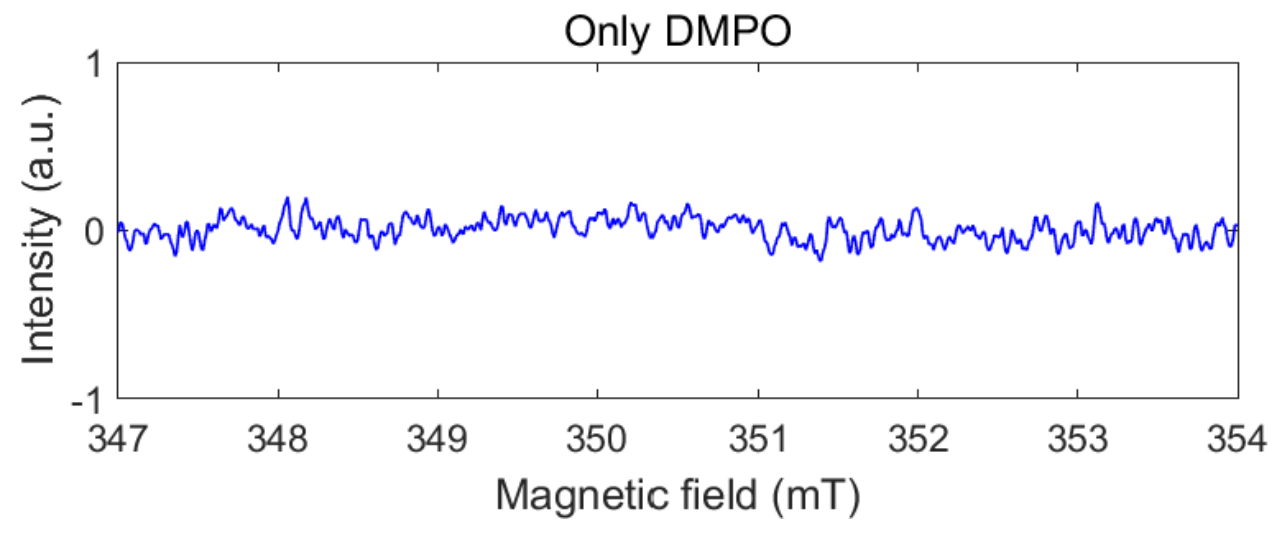

DOS Format

ANZ 1024

MIN -42895.570313

MAX 44536.429688

JSS 0

GST 3462.228475

GSI 99.975580

JUN G

JON Bruker BioSpin GmbH

JEX field-sweep

JNS 4

JSD 4

CCF 1

HCF 3512.228475 
HSW 100.000000

EMF 3462.228475

RCT 20.000000

RTC 40.960000

RRG 8.933672e+003

ROF 2.700000

RMA 0.500000

MF 9.842960

MP 1.904e+001

Reaction A: 1a $+\mathrm{B}_{2} \operatorname{pin}_{2}+t$-BuOLi

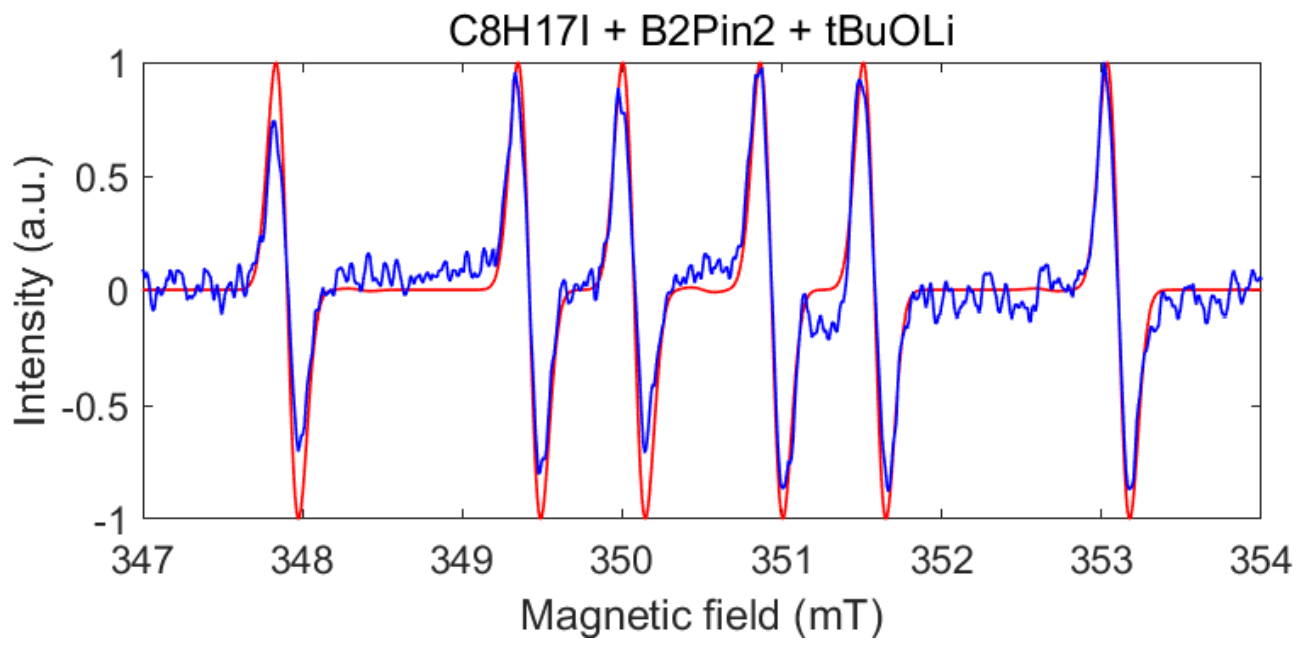

DOS Format

ANZ 1024

MIN - 155390.484375

MAX 166050.515625

JSS 0

GST 3462.228475 
GSI 99.975580

JUN G

JON Bruker BioSpin GmbH

JEX field-sweep

JNS 4

JSD 4

CCF 1

HCF 3512.228475

HSW 100.000000

EMF 3462.228475

RCT 20.000000

RTC 40.960000

RRG 8.933672e+003

ROF 2.700000

RMA 0.500000

MF 9.842752

MP $1.904 \mathrm{e}+001$

Reaction B: 1a-F $\mathbf{F}_{17}+\mathbf{B}_{2}$ pin $_{2}+t-$ BuOLi

Note: this reaction was continued for $90 \mathrm{~min}$ to obtain a maximum signal-noise ratio (at 10 min smaller amount of the same signal was found, may be due to the low reactivity of $\mathbf{1 a - \mathbf { F } _ { \mathbf { 1 7 } }}$ ). And each EPR scan was measured for $60 \mathrm{~s}$. 


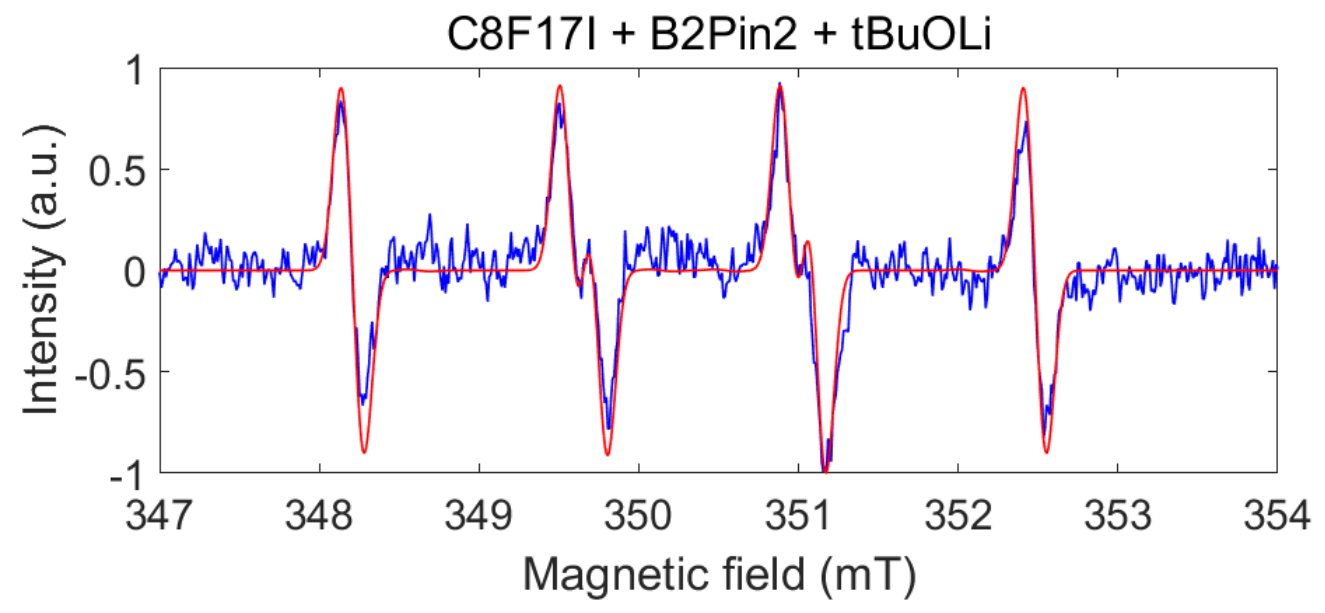

DOS Format

ANZ 1024

MIN - 155390.484375

MAX 166050.515625

JSS 0

GST 3462.228475

GSI 99.975580

JUN G

JON Bruker BioSpin GmbH

JEX field-sweep

JNS 4

JSD 4

CCF 1

HCF 3512.228475

HSW 100.000000

EMF 3462.228475

RCT 20.000000 
RTC 40.960000

RRG 8.933672e+003

ROF 2.700000

RMA 0.500000

MF 9.842752

MP $1.904 \mathrm{e}+001$

Reaction C: 1a-F $17+\mathbf{B}_{2}$ pin $_{2}$

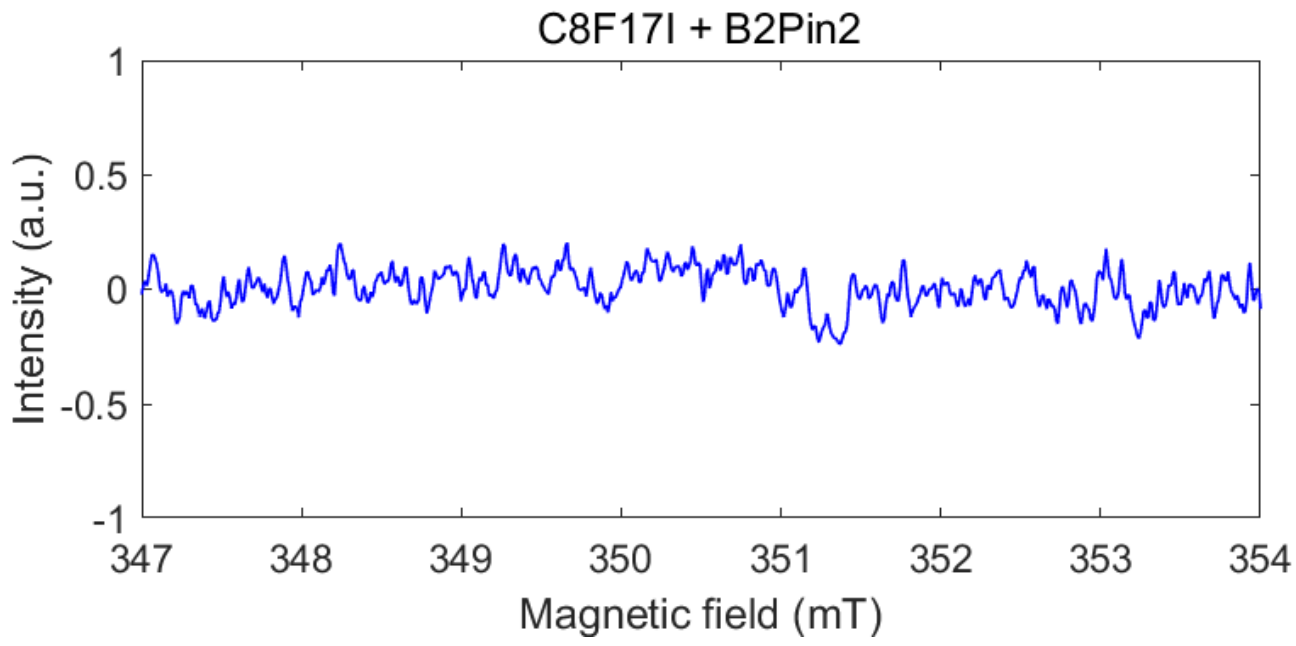

DOS Format

ANZ 1024

MIN -46533.207031

MAX 53671.792969

JSS 0

GST 3462.228475

GSI 99.975580

JUN G 
JON Bruker BioSpin GmbH

JEX field-sweep

JNS 4

JSD 4

CCF 1

HCF 3512.228475

HSW 100.000000

EMF 3462.228475

RCT 20.000000

RTC 40.960000

RRG 8.933672e+003

ROF 2.700000

RMA 0.500000

MF 9.843080

MP $1.907 \mathrm{e}+001$

Reaction D: $B_{2}$ pin $_{2}+t$-BuOLi

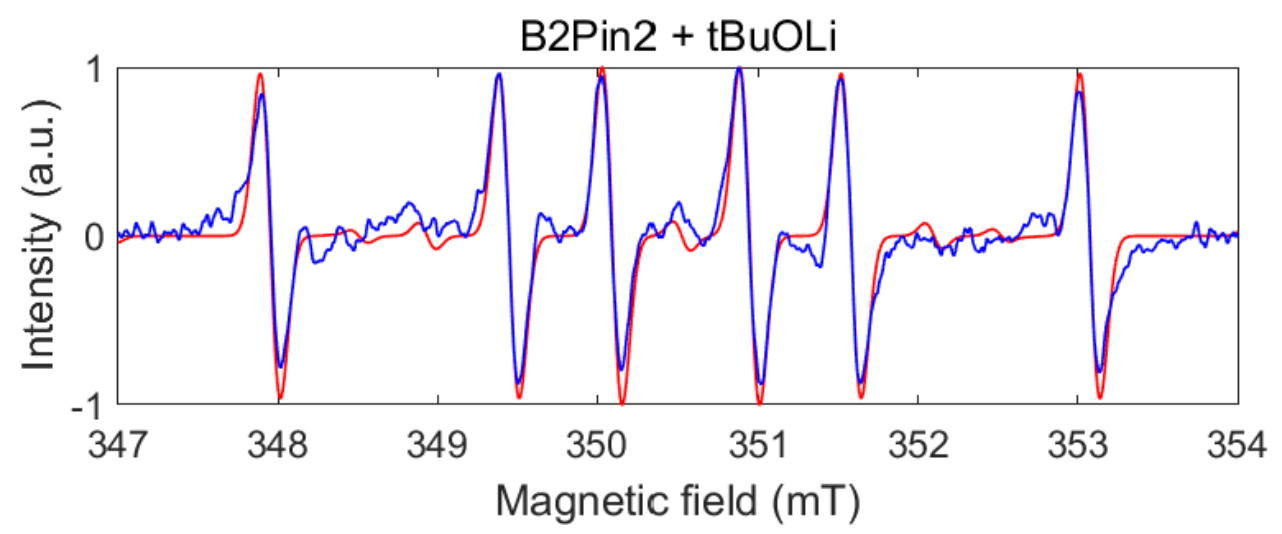

DOS Format 
ANZ 1024

MIN -222387.937500

MAX 247048.062500

JSS 0

GST 3462.228475

GSI 99.975580

JUN G

JON Bruker BioSpin GmbH

JEX field-sweep

JNS 4

JSD 4

CCF 1

HCF 3512.228475

HSW 100.000000

EMF 3462.228475

RCT 20.000000

RTC 40.960000

RRG 8.933672e+003

ROF 2.700000

RMA 0.500000

MF 9.843340

MP $1.909 e+001$ 
Reaction E: $1 \mathrm{a}-\mathrm{F}_{17}+t-\mathrm{BuOLi}$

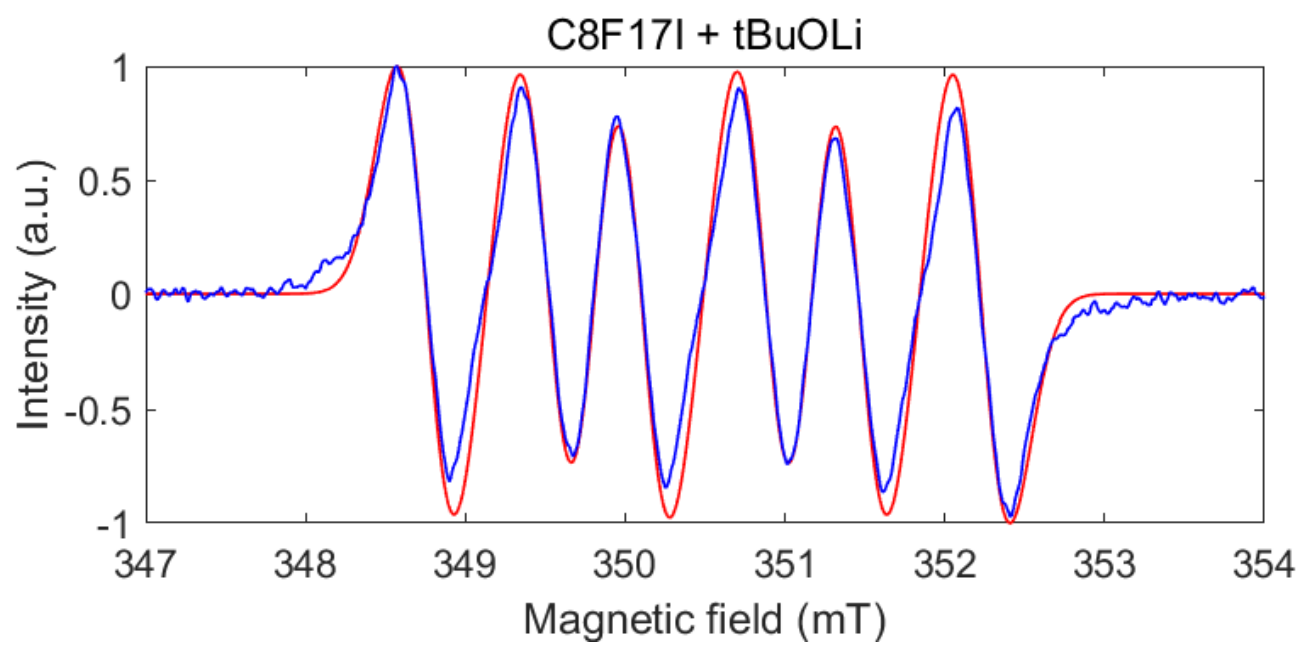

DOS Format

ANZ 1024

MIN -556035.062500

MAX 572018.937500

JSS 0

GST 3462.228475

GSI 99.975580

JUN G

JON Bruker BioSpin GmbH

JEX field-sweep

JNS 4

JSD 4

CCF 1

HCF 3512.228475

HSW 100.000000

EMF 3462.228475 
RCT 20.000000

RTC 40.960000

RRG 8.933672e+003

ROF 2.700000

RMA 0.500000

MF 9.843120

MP 1.902e+001 


\subsection{Simulations}

Reaction A: suggested DMPO. $\mathrm{C}_{8} \mathrm{H}_{17}-n$, residual $=0.0939$.

\begin{tabular}{|cccccc|}
\hline React. A & $g$ value & linewidth $(\mathrm{G})$ & $A_{\mathrm{N}}(\mathrm{G})$ & $A_{\mathrm{H}}(\mathrm{G})$ & Comments \\
Exp & 2.00633 & 1.667 & 15.16 & 21.66 & \\
Ref & & & 14.2 & 20.5 & DMPO. $_{2} \mathrm{H}_{5}$, in benzene \\
& & & 16.3 & 23.5 & DMPO. $_{2} \mathrm{H}_{5}$, in water \\
\hline
\end{tabular}

Reaction B: suggested DMPO.OC ${ }_{8} \mathrm{~F}_{17}-n$, residual $=0.0923$.

\begin{tabular}{|cccccc|}
\hline React.B & $g$ value & linewidth $(\mathrm{G})$ & $A_{\mathrm{N}}(\mathrm{G})$ & $A_{\mathrm{H}}(\mathrm{G})$ & Comments \\
Exp & 2.00692 & 1.343 & 13.74 & 15.30 & $A_{\mathrm{F}}=0.67 \mathrm{G}$ \\
Ref & & & 13.2 & 15.5 & $\mathrm{DMPO}^{\mathrm{C} F_{3}}$, in benzene, with \\
& & & & & $A_{\mathrm{F}}=1.01 \mathrm{G}^{34}$ \\
\hline
\end{tabular}

Reaction D: Radical 1 (suggested DMPO $\mathrm{CH}_{2} \mathrm{OH}$ ) : Radical 2 (suggested DMPO.H) = 1 : 0.0624 , residual $=0.0788$.

\begin{tabular}{|cccccc|}
\hline Radical 1 & $g$ value & linewidth $(\mathrm{G})$ & $A_{\mathrm{N}}(\mathrm{G})$ & $A_{\mathrm{H}}(\mathrm{G})$ & Comments \\
Exp & 2.00638 & 1.485 & 14.91 & 21.37 & \\
Ref & - & - & 14.7 & 20.7 & In benzene $^{34}$ \\
& - & - & 15.9 & 22.6 & In water $^{36}$ \\
Radical 2 & $g$ value & linewidth $(\mathrm{G})$ & $A_{\mathrm{N}}(\mathrm{G})$ & $A_{\mathrm{H}}(\mathrm{G})$ & Comments \\
Exp & 2.00636 & 1.302 & 15.79 & 20.08 & \\
Ref & - & - & 14.4 & 18.9 & In benzene $^{34}$ \\
& - & - & 16.6 & 22.5 & In water $^{37}$ \\
\hline
\end{tabular}

Reaction E: suggested DMPO.OMe or DMPO.OBu-t, residual $=0.0836$.

\begin{tabular}{|cccccc|}
\hline React. E & $g$ value & linewidth $(\mathrm{G})$ & $A_{\mathrm{N}}(\mathrm{G})$ & $A_{\mathrm{H}}(\mathrm{G})$ & Comments \\
Exp & 2.00651 & 4.145 & 13.51 & 7.83 & \\
Ref & - & - & 13.6 & 7.6 & DMPO.OMe, in benzene \\
& - & - & 13.1 & 7.9 & DMPO.OBu- $t$, in benzene \\
\end{tabular}




\section{DFT computational data}

All density functional theory (DFT) calculations were performed with Gaussian 09w and supported by National Supercomputing Center in Shenzhen. All geometry optimizations and vibrational frequency analysis were computed at the B3LYP (or uB3LYP for open shell systems) level of theory with $6-31+\mathrm{G}(\mathrm{d})$ basis set. On the basis of the gas phase optimized structures, the single point (SP) energies were calculated with the M062X (or uM062X for open shell systems) functional and basis set of $6-311++\mathrm{G}(\mathrm{d}, \mathrm{p})$, and solvent energy corrections were calculated using the SMD model with methanol as the solvent. For cases contain an iodine atom, a basis set of SDD potential function were used for iodine atom in the geometry optimization, vibrational frequency analysis and single point energy calculation. 


\subsection{Table of energies and lowest frequencies}

In Table S9, the energies are in unit of Hartree $(1$ Hartree $=627.5 \mathrm{kCal} / \mathrm{mol}=2625$ $\mathrm{kJ} / \mathrm{mol}$ ), and the lowest frequencies are in unit of $\mathrm{cm}^{-1}$. A 'negative frequency' means imaginary frequency, e.g. -173.53 means $173.53 i \mathrm{~cm}^{-1}$.

(a) Gibbs free energy profile for C-B bond formation pathways with $B_{2}$ pin $_{2}$
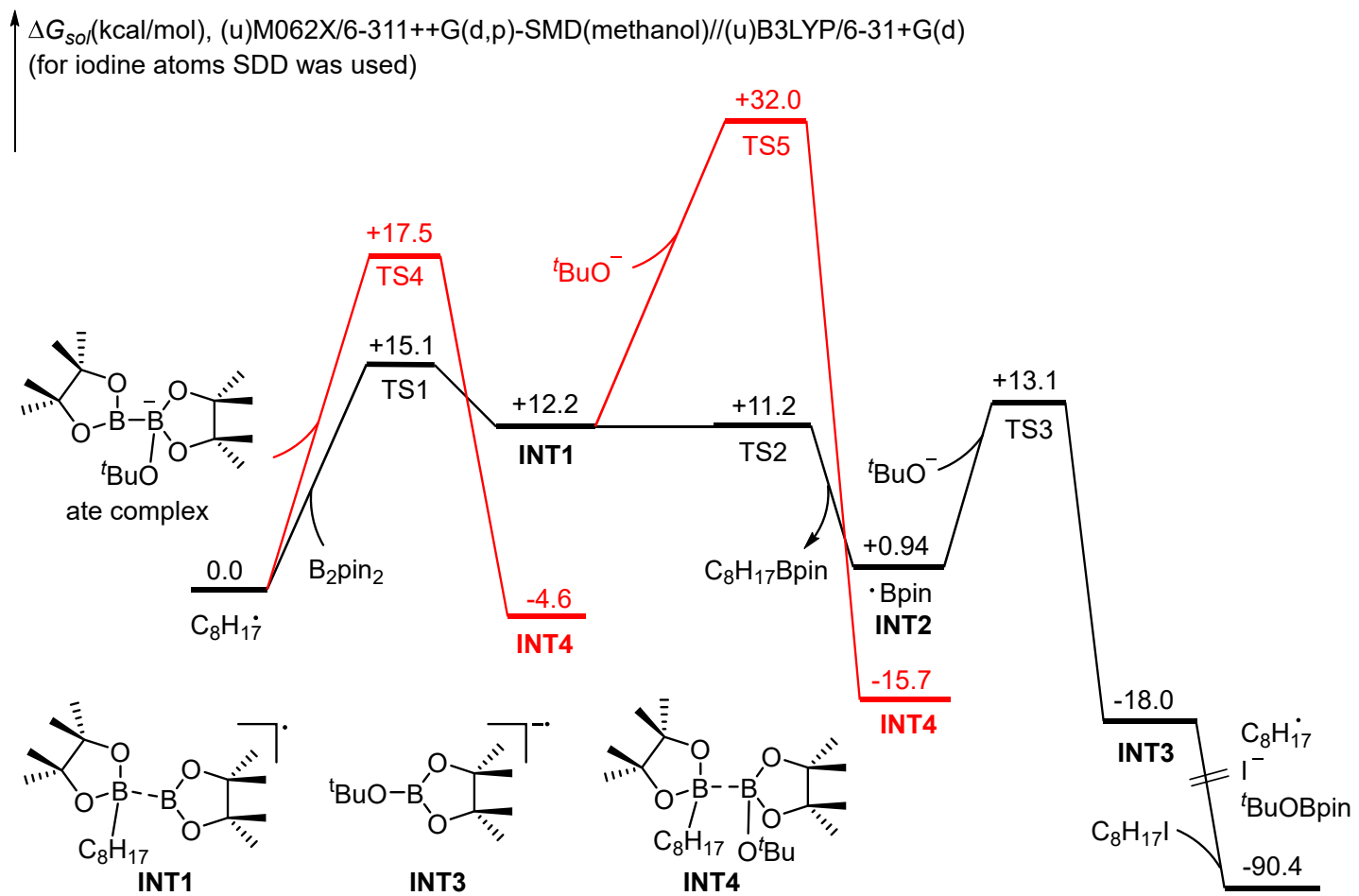

(b) Gibbs free energy profile for C-B bond formation pathways with $B_{2}$ pin $_{2}$ and $B_{2}$ cat $_{2}$

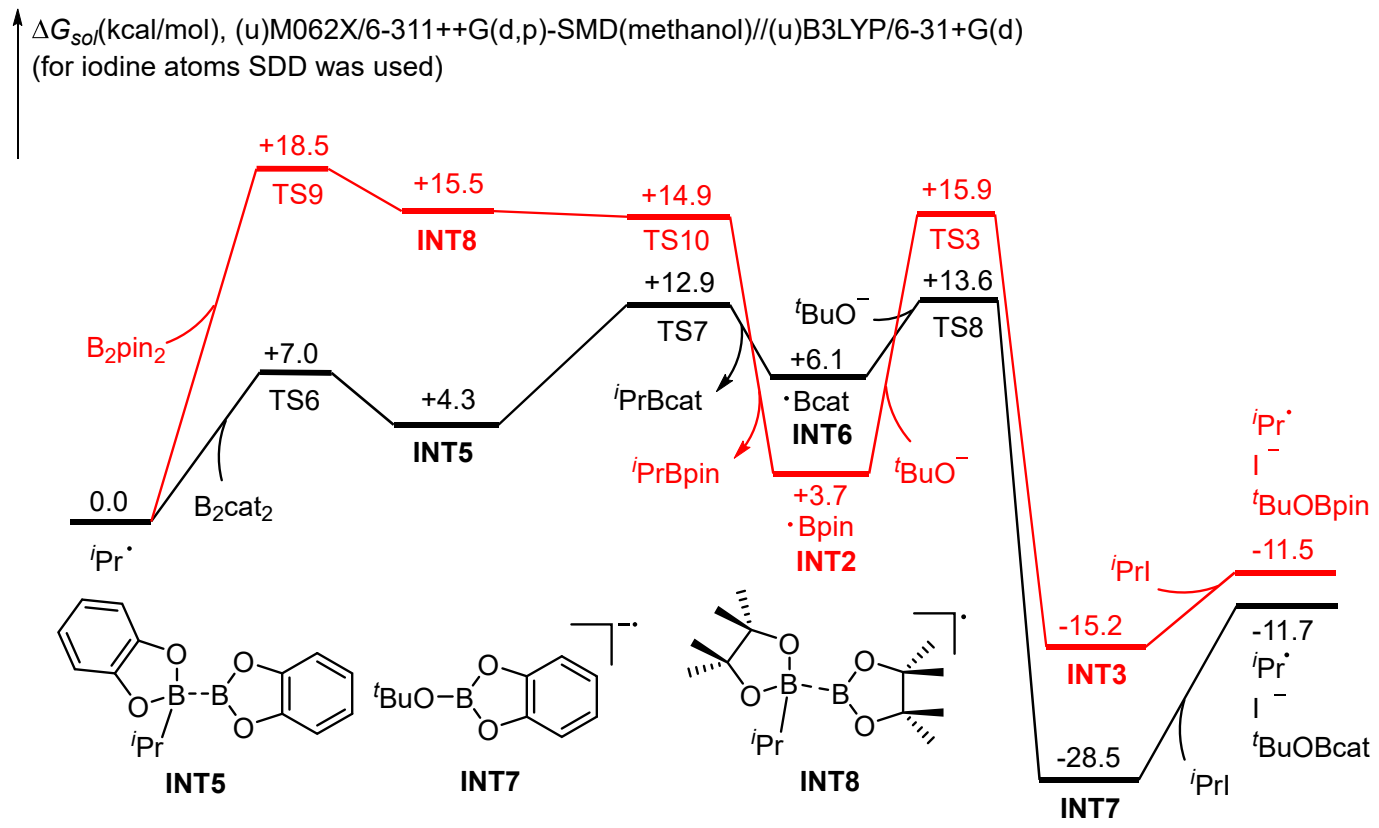




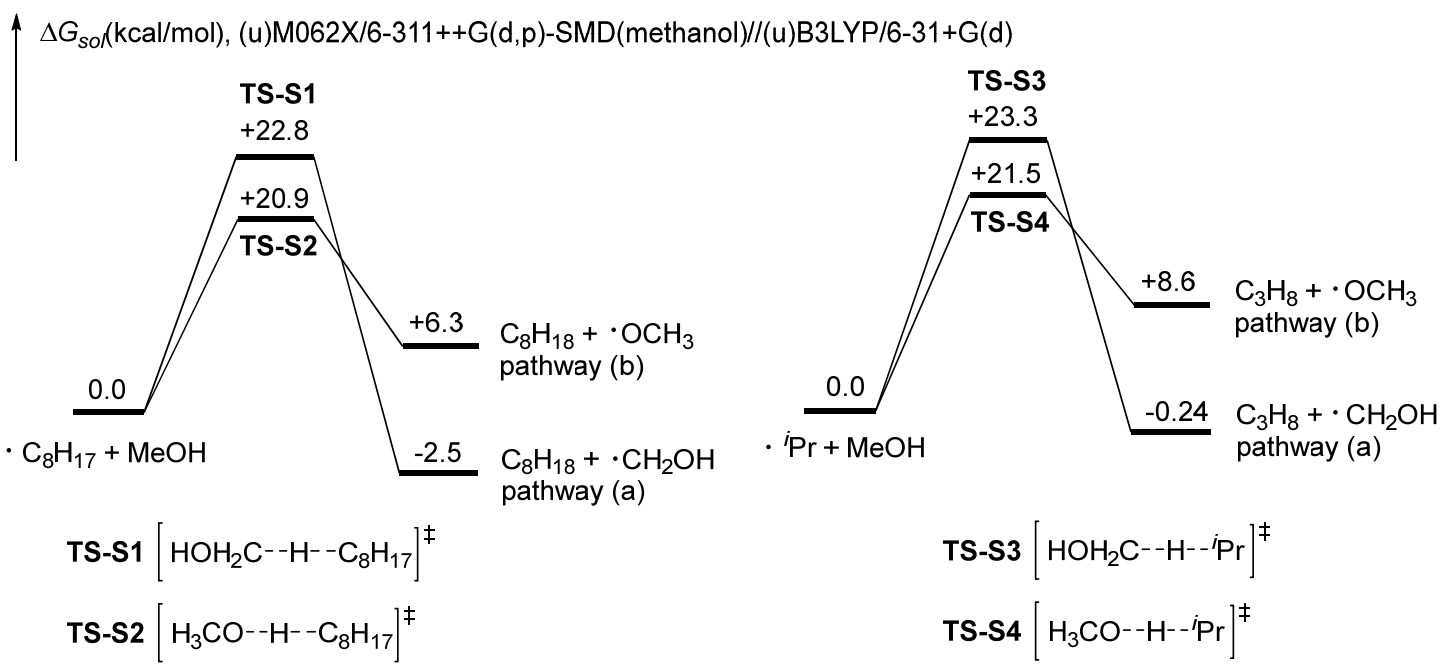

Table S9. Energies and lowest frequencies

\begin{tabular}{|c|c|c|c|c|c|c|}
\hline Structure & SP energy & $\mathrm{ZPE}$ & $\mathrm{TCH}$ & TCG & G & $\begin{array}{l}\text { Lowest } \\
\text { frequency }\end{array}$ \\
\hline${ }^{n} \mathrm{C}_{8} \mathrm{H}_{17} \bullet$ & -314.953523 & 0.231629 & 0.244096 & 0.193292 & -314.760231 & 53.06 \\
\hline $\mathrm{B}_{2} \mathrm{pin}_{2}$ & -822.449694 & 0.364287 & 0.385081 & 0.315828 & -822.133866 & 5.02 \\
\hline TS1 & -1137.402809 & 0.597927 & 0.630635 & 0.532745 & -1136.870064 & -173.53 \\
\hline INT1 & -1137.408912 & 0.599248 & 0.632056 & 0.534257 & -1136.874655 & 13.33 \\
\hline TS2 & -1137.409139 & 0.598891 & 0.631415 & 0.532927 & -1136.876212 & -106.68 \\
\hline${ }^{n} \mathrm{C}_{8} \mathrm{H}_{17}$ Bpin & -726.266339 & 0.419049 & 0.440865 & 0.367566 & -725.898773 & 15.70 \\
\hline •Bpin (INT2) & -411.140861 & 0.180061 & 0.190437 & 0.147033 & -410.993828 & 89.72 \\
\hline${ }^{\mathrm{BuO}}$ & -233.136953 & 0.120550 & 0.127871 & 0.091854 & -233.045099 & 212.71 \\
\hline TS3 & -644.274755 & 0.301456 & 0.319298 & 0.255227 & -644.019528 & -48.45 \\
\hline INT3 & -644.334430 & 0.307654 & 0.324729 & 0.265280 & -644.069150 & 35.69 \\
\hline${ }^{n} \mathrm{C}_{8} \mathrm{H}_{17} \mathrm{I}$ & -326.396890 & 0.237322 & 0.250609 & 0.195797 & -326.201093 & 36.67 \\
\hline $\mathrm{I}^{-}$ & -11.552811 & 0.000000 & 0.002360 & -0.016848 & -11.569659 & None \\
\hline${ }^{t} \mathrm{BuOBpin}$ & -644.323066 & 0.309339 & 0.326496 & 0.267367 & -644.055699 & 33.93 \\
\hline Ate complex & -1055.628790 & 0.486886 & 0.514773 & 0.432267 & -1055.196523 & 24.94 \\
\hline TS4 & -1370.576861 & 0.720007 & 0.759940 & 0.648058 & -1369.928803 & -220.72 \\
\hline TS5 & -1370.533153 & 0.720589 & 0.760714 & 0.644894 & -1369.888259 & -47.27 \\
\hline INT4 & -1370.616977 & 0.723879 & 0.763623 & 0.652834 & -1369.964143 & 16.63 \\
\hline${ }^{i} \mathrm{Pr}$ & -118.435499 & 0.088224 & 0.094360 & 0.060956 & -118.374543 & 109.68 \\
\hline
\end{tabular}




\begin{tabular}{|c|c|c|c|c|c|c|}
\hline $\mathrm{B}_{2} \mathrm{cat}_{2}$ & -812.799312 & 0.187480 & 0.201201 & 0.146077 & -812.653235 & 22.80 \\
\hline TS6 & -931.245901 & 0.278273 & 0.297305 & 0.229254 & -931.016647 & -212.53 \\
\hline INT5 & -931.252414 & 0.279904 & 0.298763 & 0.231431 & -931.020983 & 14.51 \\
\hline TS7 & -931.235912 & 0.279545 & 0.298475 & 0.228700 & -931.007212 & -83.65 \\
\hline •Bcat (INT6) & -406.309804 & 0.091700 & 0.098543 & 0.060939 & -406.248865 & 231.64 \\
\hline${ }^{i}$ PrBcat & -524.918909 & 0.187599 & 0.199226 & 0.149693 & -524.769216 & 9.65 \\
\hline TS8 & -639.446837 & 0.212303 & 0.227241 & 0.164928 & -639.281909 & -30.26 \\
\hline INT7 & -639.527885 & 0.218183 & 0.231971 & 0.178826 & -639.349059 & 40.31 \\
\hline${ }^{i} \operatorname{PrI}$ & -130.000524 & 0.094050 & 0.100573 & 0.063845 & -129.936679 & 240.08 \\
\hline${ }^{t} \mathrm{BuOB}$ cat & -639.495907 & 0.220592 & 0.234406 & 0.181146 & -639.314761 & 40.09 \\
\hline TS9 & -940.881358 & 0.455736 & 0.481451 & 0.402361 & -940.478997 & -209.13 \\
\hline INT8 & -940.887708 & 0.457072 & 0.482895 & 0.404014 & -940.483694 & 20.64 \\
\hline TS10 & -940.887206 & 0.456629 & 0.482236 & 0.402573 & -940.484633 & -104.22 \\
\hline${ }^{i}$ PrBpin & -529.744564 & 0.276107 & 0.291176 & 0.235918 & -529.508646 & 15.53 \\
\hline $\mathrm{MeOH}$ & -115.713801 & 0.051299 & 0.055559 & 0.028551 & -115.685250 & 329.04 \\
\hline - $\mathrm{CH}_{2} \mathrm{OH}$ & -115.049633 & 0.037294 & 0.041553 & 0.014313 & -115.035320 & 436.50 \\
\hline - $\mathrm{OCH}_{3}$ & -115.034949 & 0.036602 & 0.040567 & 0.013660 & -115.021289 & 723.18 \\
\hline${ }^{n} \mathrm{C}_{8} \mathrm{H}_{18}$ & -315.623849 & 0.246582 & 0.258588 & 0.209695 & -315.414154 & 53.34 \\
\hline $\mathrm{C}_{3} \mathrm{H}_{8}$ & -119.102893 & 0.103719 & 0.109191 & 0.078045 & -119.024848 & 218.64 \\
\hline TS-S1 & -430.645131 & 0.280882 & 0.296615 & 0.235928 & -430.409203 & -1710.91 \\
\hline TS-S2 & -430.646722 & 0.280281 & 0.296090 & 0.234590 & -430.412132 & -1638.06 \\
\hline TS-S3 & -234.126995 & 0.138041 & 0.147268 & 0.104302 & -234.022693 & -1728.77 \\
\hline TS-S4 & -234.129399 & 0.137672 & 0.146877 & 0.103915 & -234.025484 & -1502.14 \\
\hline
\end{tabular}




\subsection{Cartesian coordinates of the structures}

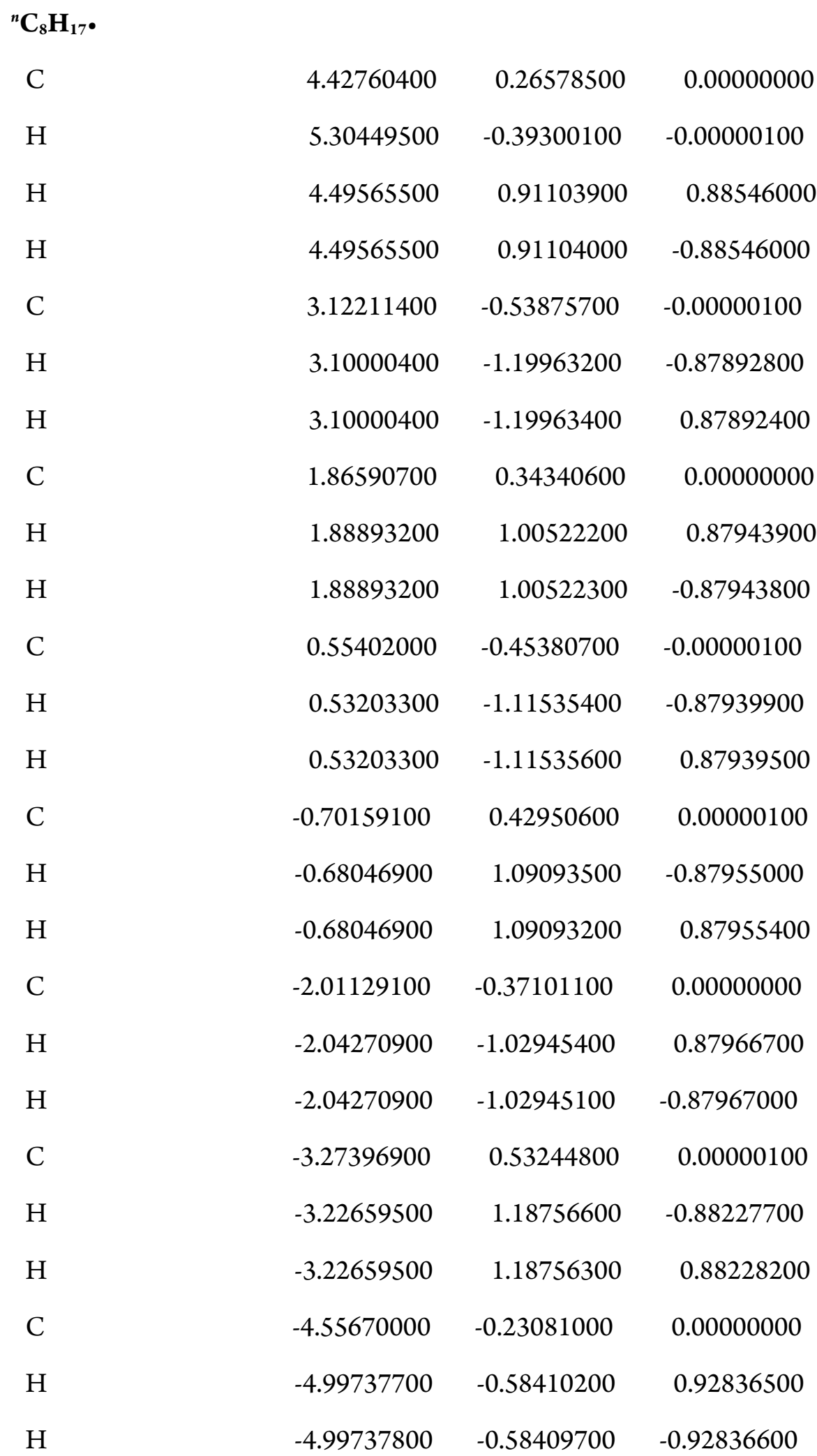

\section{$\mathbf{B}_{2} \operatorname{pin}_{2}$}




\begin{tabular}{|c|c|c|c|}
\hline $\mathrm{C}$ & -3.01075700 & -0.47450500 & 0.62998900 \\
\hline $\mathrm{C}$ & -3.01078200 & 0.47449900 & -0.62998100 \\
\hline $\mathrm{C}$ & 3.01076100 & -0.63001500 & -0.47447500 \\
\hline $\mathrm{C}$ & 3.01077900 & 0.63001000 & 0.47447200 \\
\hline B & -0.85203300 & 0.00003600 & -0.00001200 \\
\hline B & 0.85202500 & 0.00003200 & -0.00000700 \\
\hline $\mathrm{O}$ & 1.61779300 & 0.68881000 & 0.91270800 \\
\hline $\mathrm{O}$ & -1.61781700 & 0.91280300 & -0.68870000 \\
\hline $\mathrm{O}$ & -1.61777600 & -0.91275800 & 0.68869000 \\
\hline $\mathrm{O}$ & 1.61777800 & -0.68876900 & -0.91272000 \\
\hline $\mathrm{C}$ & -3.29482600 & -0.25530400 & -1.95051200 \\
\hline $\mathrm{H}$ & -4.34165500 & -0.57186100 & -2.01858800 \\
\hline $\mathrm{H}$ & -3.08627000 & 0.42506300 & -2.78258700 \\
\hline $\mathrm{H}$ & -2.65589600 & -1.13640500 & -2.06880800 \\
\hline $\mathrm{C}$ & -3.90178000 & 1.70987300 & -0.51345100 \\
\hline $\mathrm{H}$ & -4.95425000 & 1.42150700 & -0.40318000 \\
\hline $\mathrm{H}$ & -3.62002900 & 2.33500100 & 0.33714600 \\
\hline $\mathrm{H}$ & -3.80950400 & 2.31489400 & -1.42164300 \\
\hline $\mathrm{C}$ & -3.29481200 & 0.25529100 & 1.95052100 \\
\hline $\mathrm{H}$ & -2.65591100 & 1.13641400 & 2.06880800 \\
\hline $\mathrm{H}$ & -4.34165100 & 0.57181100 & 2.01860900 \\
\hline $\mathrm{H}$ & -3.08622500 & -0.42506700 & 2.78259700 \\
\hline $\mathrm{C}$ & -3.90171000 & -1.70991100 & 0.51346600 \\
\hline $\mathrm{H}$ & -3.61994600 & -2.33502400 & -0.33713800 \\
\hline $\mathrm{H}$ & -3.80939800 & -2.31493300 & 1.42165300 \\
\hline $\mathrm{H}$ & -4.95419300 & -1.42158600 & 0.40321100 \\
\hline $\mathrm{C}$ & 3.90171300 & 0.51351800 & 1.70989100 \\
\hline $\mathrm{H}$ & 4.95419400 & 0.40320800 & 1.42158000 \\
\hline $\mathrm{H}$ & 3.80942600 & 1.42174200 & 2.31486200 \\
\hline $\mathrm{H}$ & 3.61992000 & -0.33704300 & 2.33505000 \\
\hline
\end{tabular}




$\begin{array}{lrrr}\mathrm{C} & 3.29489500 & 1.95049700 & -0.25538100 \\ \mathrm{H} & 3.08633300 & 2.78261500 & 0.42493200 \\ \mathrm{H} & 4.34174300 & 2.01852100 & -0.57188500 \\ \mathrm{H} & 2.65601400 & 2.06877400 & -1.13652000 \\ \mathrm{C} & 3.29483000 & -1.95051200 & 0.25538000 \\ \mathrm{H} & 4.34167300 & -2.01856900 & 0.57189300 \\ \mathrm{H} & 2.65593800 & -2.06877000 & 1.13651300 \\ \mathrm{H} & 3.08624800 & -2.78262200 & -0.42493700 \\ \mathrm{C} & 3.90170900 & -0.51355100 & -1.70988800 \\ \mathrm{H} & 3.61993800 & 0.33701300 & -2.33505200 \\ \mathrm{H} & 4.95419000 & -0.40326500 & -1.42157100 \\ \mathrm{H} & 3.80940500 & -1.42177500 & -2.31485600\end{array}$

TS1

\begin{tabular}{lrrr} 
C & -1.83798200 & 3.17251200 & -0.67619300 \\
C & -1.56786800 & 3.06651700 & 0.87645400 \\
C & -2.26014700 & -2.80742300 & 0.76438200 \\
C & -3.21310400 & -2.48490500 & -0.45651800 \\
B & -1.62773900 & 0.96615800 & -0.06631800 \\
B & -1.69568200 & -0.75635100 & -0.17166300 \\
O & -2.54704900 & -1.37219400 & -1.10432200 \\
O & -1.74756000 & 1.63934600 & 1.12758100 \\
$\mathrm{O}$ & -1.52636000 & 1.82456300 & -1.13979900 \\
$\mathrm{O}$ & -1.58392800 & -1.54318600 & 0.98046400 \\
$\mathrm{C}$ & -0.12716500 & 3.40933500 & 1.27999500 \\
$\mathrm{H}$ & 0.07261800 & 4.48282900 & 1.18637800 \\
$\mathrm{H}$ & 0.02527100 & 3.12037000 & 2.32497000 \\
$\mathrm{H}$ & 0.60391500 & 2.86772600 & 0.67165800 \\
$\mathrm{C}$ & -2.54821300 & 3.83612600 & 1.76097300 \\
$\mathrm{H}$ & -2.48857100 & 4.91372100 & 1.56513200 \\
& & 51 & \\
\hline & & & \\
\hline & & & \\
\hline
\end{tabular}




\begin{tabular}{|c|c|c|c|}
\hline $\mathrm{H}$ & -3.57917200 & 3.50966400 & 1.60481500 \\
\hline $\mathrm{H}$ & -2.29872900 & 3.66852300 & 2.81410200 \\
\hline $\mathrm{C}$ & -3.31014000 & 3.42640800 & -1.03019700 \\
\hline $\mathrm{H}$ & -3.97280800 & 2.71598700 & -0.52575400 \\
\hline $\mathrm{H}$ & -3.62094900 & 4.44297400 & -0.76401500 \\
\hline $\mathrm{H}$ & -3.44093500 & 3.29749500 & -2.10953100 \\
\hline $\mathrm{C}$ & -0.94567800 & 4.16119800 & -1.42546400 \\
\hline $\mathrm{H}$ & 0.11395000 & 3.91828000 & -1.31444900 \\
\hline $\mathrm{H}$ & -1.18691900 & 4.13536700 & -2.49347600 \\
\hline $\mathrm{H}$ & -1.10888500 & 5.18440700 & -1.06558900 \\
\hline $\mathrm{C}$ & -3.37440700 & -3.61738900 & -1.47249900 \\
\hline $\mathrm{H}$ & -3.84201300 & -4.49553300 & -1.01035800 \\
\hline $\mathrm{H}$ & -4.01889100 & -3.28192200 & -2.29205200 \\
\hline $\mathrm{H}$ & -2.41607800 & -3.91886000 & -1.90282800 \\
\hline $\mathrm{C}$ & -4.60046600 & -1.97635200 & -0.02969700 \\
\hline $\mathrm{H}$ & -5.12971100 & -1.61160200 & -0.91629700 \\
\hline $\mathrm{H}$ & -5.20131000 & -2.77028900 & 0.42834700 \\
\hline $\mathrm{H}$ & -4.52053000 & -1.14662200 & 0.67996500 \\
\hline $\mathrm{C}$ & -1.19189700 & -3.87021800 & 0.45711100 \\
\hline $\mathrm{H}$ & -1.63549600 & -4.86901000 & 0.37239700 \\
\hline $\mathrm{H}$ & -0.65015400 & -3.65939000 & -0.46906800 \\
\hline $\mathrm{H}$ & -0.46605400 & -3.88753700 & 1.27702400 \\
\hline $\mathrm{C}$ & -2.97998600 & -3.18703400 & 2.06124500 \\
\hline $\mathrm{H}$ & -3.64164800 & -2.38846400 & 2.40475700 \\
\hline $\mathrm{H}$ & -3.57054900 & -4.10203800 & 1.92943100 \\
\hline $\mathrm{H}$ & -2.24090400 & -3.37057500 & 2.84862300 \\
\hline $\mathrm{C}$ & 1.31875200 & -0.47164900 & -0.18426000 \\
\hline $\mathrm{H}$ & 1.23883100 & -1.09248000 & 0.71723100 \\
\hline $\mathrm{H}$ & 1.26388000 & 0.57382800 & 0.14716900 \\
\hline $\mathrm{C}$ & 2.69763400 & -0.70848800 & -0.84556300 \\
\hline
\end{tabular}




\begin{tabular}{|c|c|c|c|}
\hline $\mathrm{H}$ & 2.77192000 & -0.09812600 & -1.75723100 \\
\hline $\mathrm{H}$ & 2.76812900 & -1.75694000 & -1.16987600 \\
\hline $\mathrm{C}$ & 3.87444600 & -0.38104200 & 0.08548600 \\
\hline $\mathrm{H}$ & 3.79476300 & 0.66548600 & 0.41645700 \\
\hline $\mathrm{H}$ & 3.80034100 & -0.99574000 & 0.99510700 \\
\hline $\mathrm{C}$ & 5.24542800 & -0.60228500 & -0.56900200 \\
\hline $\mathrm{H}$ & 5.31357200 & 0.00977500 & -1.48132400 \\
\hline $\mathrm{H}$ & 5.32563900 & -1.64953300 & -0.89816600 \\
\hline $\mathrm{C}$ & 6.42791100 & -0.26957400 & 0.35147100 \\
\hline $\mathrm{H}$ & 6.34583000 & 0.77639600 & 0.68489500 \\
\hline $\mathrm{H}$ & 6.36530400 & -0.88506700 & 1.26200500 \\
\hline $\mathrm{C}$ & 7.79777000 & -0.48191100 & -0.30808300 \\
\hline $\mathrm{H}$ & 7.88202700 & -1.52766400 & -0.63835900 \\
\hline $\mathrm{H}$ & 7.85858400 & 0.13133100 & -1.21916700 \\
\hline $\mathrm{C}$ & 0.18668200 & -0.78330300 & -1.12426800 \\
\hline $\mathrm{H}$ & 0.01938000 & -0.08886100 & -1.94623600 \\
\hline $\mathrm{H}$ & 0.09032900 & -1.82666700 & -1.42306400 \\
\hline $\mathrm{C}$ & 8.97447700 & -0.14202000 & 0.61442200 \\
\hline $\mathrm{H}$ & 8.96178500 & -0.76325500 & 1.51941100 \\
\hline $\mathrm{H}$ & 9.93648700 & -0.30395100 & 0.11315200 \\
\hline $\mathrm{H}$ & 8.93775900 & 0.90768100 & 0.93356700 \\
\hline
\end{tabular}

\section{INT 1}

$\begin{array}{lccc}\text { C } & -1.62971600 & 3.03356500 & -0.67456400 \\ \text { C } & -1.91868400 & 2.82863500 & 0.86544300 \\ \text { C } & -2.42462200 & -2.67987100 & 0.73881100 \\ \text { C } & -3.27020400 & -2.14268600 & -0.48473000 \\ \text { B } & -1.44387100 & 0.82749300 & -0.12633700 \\ \text { B } & -1.23165200 & -1.00428000 & -0.36285700 \\ \text { O } & -2.29228400 & -1.38718900 & -1.23917500 \\ & & 53 & \end{array}$




\begin{tabular}{|c|c|c|c|}
\hline $\mathrm{O}$ & -2.06192800 & 1.36884000 & 0.96344300 \\
\hline $\mathrm{O}$ & -1.04391200 & 1.74239000 & -1.05531700 \\
\hline $\mathrm{O}$ & -1.37614700 & -1.69388700 & 0.86874800 \\
\hline $\mathrm{C}$ & -0.74371300 & 3.21163800 & 1.77332800 \\
\hline $\mathrm{H}$ & -0.59884600 & 4.29732800 & 1.80346300 \\
\hline $\mathrm{H}$ & -0.95319000 & 2.86370900 & 2.78988000 \\
\hline $\mathrm{H}$ & 0.19050500 & 2.74517600 & 1.44525400 \\
\hline $\mathrm{C}$ & -3.20740700 & 3.46891100 & 1.37532300 \\
\hline $\mathrm{H}$ & -3.16713000 & 4.55968000 & 1.26800200 \\
\hline $\mathrm{H}$ & -4.08562600 & 3.09846800 & 0.84137800 \\
\hline $\mathrm{H}$ & -3.33532500 & 3.23806500 & 2.43808100 \\
\hline $\mathrm{C}$ & -2.89519000 & 3.20314500 & -1.52424900 \\
\hline $\mathrm{H}$ & -3.62472500 & 2.41227100 & -1.32384500 \\
\hline $\mathrm{H}$ & -3.37272100 & 4.17280000 & -1.34412500 \\
\hline $\mathrm{H}$ & -2.62089900 & 3.14569300 & -2.58242300 \\
\hline $\mathrm{C}$ & -0.62207400 & 4.13146500 & -1.00604600 \\
\hline $\mathrm{H}$ & 0.34552600 & 3.95307500 & -0.53133700 \\
\hline $\mathrm{H}$ & -0.46482000 & 4.16934900 & -2.08902800 \\
\hline $\mathrm{H}$ & -0.99566000 & 5.11069700 & -0.68303400 \\
\hline $\mathrm{C}$ & -3.84196800 & -3.22818000 & -1.40079300 \\
\hline $\mathrm{H}$ & -4.54213700 & -3.87142300 & -0.85356300 \\
\hline $\mathrm{H}$ & -4.38712900 & -2.75874500 & -2.22682800 \\
\hline $\mathrm{H}$ & -3.05527000 & -3.85318300 & -1.83029000 \\
\hline $\mathrm{C}$ & -4.39532600 & -1.17719200 & -0.07522000 \\
\hline $\mathrm{H}$ & -4.79865900 & -0.70420300 & -0.97759700 \\
\hline $\mathrm{H}$ & -5.21320500 & -1.70730100 & 0.42622800 \\
\hline $\mathrm{H}$ & -4.03065100 & -0.39065300 & 0.59093600 \\
\hline $\mathrm{C}$ & -1.73386300 & -4.02512400 & 0.45398300 \\
\hline $\mathrm{H}$ & -2.45670500 & -4.84775700 & 0.40501800 \\
\hline $\mathrm{H}$ & -1.17448900 & -3.99951300 & -0.48648100 \\
\hline
\end{tabular}




\begin{tabular}{|c|c|c|c|}
\hline $\mathrm{H}$ & -1.02641400 & -4.23636900 & 1.26267500 \\
\hline $\mathrm{C}$ & -3.18607800 & -2.76471900 & 2.06306500 \\
\hline $\mathrm{H}$ & -3.56647200 & -1.78807700 & 2.37157200 \\
\hline $\mathrm{H}$ & -4.02791000 & -3.46412200 & 1.98735800 \\
\hline $\mathrm{H}$ & -2.51358400 & -3.12672700 & 2.84838300 \\
\hline $\mathrm{C}$ & 1.44858400 & -0.59379800 & -0.10871900 \\
\hline $\mathrm{H}$ & 1.39152800 & -1.18019300 & 0.81829700 \\
\hline $\mathrm{H}$ & 1.35178900 & 0.46143200 & 0.18679100 \\
\hline $\mathrm{C}$ & 2.82720600 & -0.79694600 & -0.75893800 \\
\hline $\mathrm{H}$ & 2.87421900 & -0.21691200 & -1.69310400 \\
\hline $\mathrm{H}$ & 2.93757200 & -1.85275800 & -1.04978700 \\
\hline $\mathrm{C}$ & 4.00084700 & -0.39678000 & 0.14633400 \\
\hline $\mathrm{H}$ & 3.88796200 & 0.65769600 & 0.44207600 \\
\hline $\mathrm{H}$ & 3.95680600 & -0.98087200 & 1.07823500 \\
\hline $\mathrm{C}$ & 5.37453900 & -0.59250800 & -0.51052000 \\
\hline $\mathrm{H}$ & 5.41660600 & -0.00672800 & -1.44159900 \\
\hline $\mathrm{H}$ & 5.48641500 & -1.64613000 & -0.80902000 \\
\hline $\mathrm{C}$ & 6.55260800 & -0.19532600 & 0.38961100 \\
\hline $\mathrm{H}$ & 6.43968000 & 0.85698900 & 0.69312900 \\
\hline $\mathrm{H}$ & 6.51603400 & -0.78527100 & 1.31841000 \\
\hline $\mathrm{C}$ & 7.92424900 & -0.38363900 & -0.27348300 \\
\hline $\mathrm{H}$ & 8.03773100 & -1.43461200 & -0.57746100 \\
\hline $\mathrm{H}$ & 7.96134400 & 0.20728400 & -1.20046200 \\
\hline $\mathrm{C}$ & 0.29448300 & -0.98309300 & -1.03469100 \\
\hline $\mathrm{H}$ & 0.28752000 & -0.36650600 & -1.93971400 \\
\hline $\mathrm{H}$ & 0.40526400 & -2.03341800 & -1.35103100 \\
\hline $\mathrm{C}$ & 9.09625200 & 0.01421400 & 0.63180500 \\
\hline $\mathrm{H}$ & 9.10766400 & -0.58449500 & 1.55190200 \\
\hline $\mathrm{H}$ & 10.05972800 & -0.13126400 & 0.12813900 \\
\hline $\mathrm{H}$ & 9.02992300 & 1.06996200 & 0.92540500 \\
\hline & & 55 & \\
\hline
\end{tabular}


TS2

\begin{tabular}{|c|c|c|c|}
\hline $\mathrm{C}$ & -1.22118900 & 3.15878000 & -0.65103800 \\
\hline $\mathrm{C}$ & -1.80143800 & 2.95702000 & 0.80525100 \\
\hline $\mathrm{C}$ & -2.72104700 & -2.51420600 & 0.83028900 \\
\hline $\mathrm{C}$ & -3.42283000 & -2.06313900 & -0.52363200 \\
\hline B & -1.37340900 & 0.94167100 & -0.16287000 \\
\hline B & -1.20456400 & -1.36883800 & -0.50004700 \\
\hline $\mathrm{O}$ & -2.30969700 & -1.59326200 & -1.32589600 \\
\hline $\mathrm{O}$ & -2.12264100 & 1.51369300 & 0.81605700 \\
\hline $\mathrm{O}$ & -0.72036300 & 1.80793600 & -0.97834200 \\
\hline $\mathrm{O}$ & -1.44956700 & -1.81692000 & 0.79859400 \\
\hline $\mathrm{C}$ & -0.77260300 & 3.17565500 & 1.91992500 \\
\hline $\mathrm{H}$ & -0.51393500 & 4.23546100 & 2.02228300 \\
\hline $\mathrm{H}$ & -1.19849600 & 2.83242100 & 2.86809500 \\
\hline $\mathrm{H}$ & 0.14586100 & 2.60839800 & 1.74005600 \\
\hline $\mathrm{C}$ & -3.08164800 & 3.73015700 & 1.10718400 \\
\hline $\mathrm{H}$ & -2.89982300 & 4.81087300 & 1.06247100 \\
\hline $\mathrm{H}$ & -3.88347200 & 3.48302400 & 0.40774500 \\
\hline $\mathrm{H}$ & -3.42608700 & 3.48714900 & 2.11774300 \\
\hline $\mathrm{C}$ & -2.28617400 & 3.48975000 & -1.70256300 \\
\hline $\mathrm{H}$ & -3.12385300 & 2.78634100 & -1.66538100 \\
\hline $\mathrm{H}$ & -2.67680300 & 4.50487100 & -1.56939300 \\
\hline $\mathrm{H}$ & -1.83504900 & 3.42242900 & -2.69753000 \\
\hline $\mathrm{C}$ & -0.05307000 & 4.13483200 & -0.75555000 \\
\hline $\mathrm{H}$ & 0.78418800 & 3.84014500 & -0.11895100 \\
\hline $\mathrm{H}$ & 0.30436900 & 4.16773600 & -1.78991800 \\
\hline $\mathrm{H}$ & -0.36825600 & 5.14685100 & -0.47352600 \\
\hline $\mathrm{C}$ & -4.11032200 & -3.19282400 & -1.29687600 \\
\hline $\mathrm{H}$ & -4.93650500 & -3.62020500 & -0.71592700 \\
\hline
\end{tabular}




\begin{tabular}{|c|c|c|c|}
\hline $\mathrm{H}$ & -4.52284200 & -2.79333200 & -2.22963800 \\
\hline $\mathrm{H}$ & -3.41311900 & -3.99339300 & -1.55507400 \\
\hline $\mathrm{C}$ & -4.41169200 & -0.89854900 & -0.36032600 \\
\hline $\mathrm{H}$ & -4.70815400 & -0.55017400 & -1.35603400 \\
\hline $\mathrm{H}$ & -5.31593700 & -1.21533900 & 0.17226400 \\
\hline $\mathrm{H}$ & -3.97123900 & -0.05655600 & 0.17826800 \\
\hline $\mathrm{C}$ & -2.38520200 & -4.01348800 & 0.88239100 \\
\hline $\mathrm{H}$ & -3.28835000 & -4.63091700 & 0.94884000 \\
\hline $\mathrm{H}$ & -1.81161100 & -4.32857100 & 0.00494900 \\
\hline $\mathrm{H}$ & -1.77183700 & -4.20569400 & 1.76894700 \\
\hline $\mathrm{C}$ & -3.46350300 & -2.11171000 & 2.10638400 \\
\hline $\mathrm{H}$ & -3.59355200 & -1.02910400 & 2.17296600 \\
\hline $\mathrm{H}$ & -4.44932300 & -2.59016800 & 2.15502300 \\
\hline $\mathrm{H}$ & -2.88614500 & -2.43530900 & 2.97927700 \\
\hline $\mathrm{C}$ & 1.41261500 & -0.96247900 & -0.14227600 \\
\hline $\mathrm{H}$ & 1.36694000 & -1.64661000 & 0.71649800 \\
\hline $\mathrm{H}$ & 1.27904500 & 0.04897700 & 0.26912700 \\
\hline $\mathrm{C}$ & 2.80052800 & -1.04926800 & -0.79346400 \\
\hline $\mathrm{H}$ & 2.82908400 & -0.38329800 & -1.66965700 \\
\hline $\mathrm{H}$ & 2.95444400 & -2.06821400 & -1.18135600 \\
\hline $\mathrm{C}$ & 3.95387300 & -0.68802600 & 0.15271800 \\
\hline $\mathrm{H}$ & 3.80266600 & 0.33390600 & 0.53379100 \\
\hline $\mathrm{H}$ & 3.92379300 & -1.34823600 & 1.03321400 \\
\hline $\mathrm{C}$ & 5.33845300 & -0.78160300 & -0.50353500 \\
\hline $\mathrm{H}$ & 5.36170600 & -0.13227600 & -1.39234600 \\
\hline $\mathrm{H}$ & 5.49567100 & -1.80678900 & -0.87245300 \\
\hline $\mathrm{C}$ & 6.49400300 & -0.39806200 & 0.43096900 \\
\hline $\mathrm{H}$ & 6.33811900 & 0.62792700 & 0.79901700 \\
\hline $\mathrm{H}$ & 6.47370200 & -1.04631200 & 1.32070200 \\
\hline $\mathrm{C}$ & 7.87662600 & -0.49106900 & -0.22922000 \\
\hline
\end{tabular}




$\begin{array}{lrrr}\mathrm{H} & 8.03590400 & -1.51707500 & -0.59223000 \\ \mathrm{H} & 7.89541500 & 0.15345100 & -1.12046900 \\ \mathrm{C} & 0.26615200 & -1.28112200 & -1.11490600 \\ \mathrm{H} & 0.29099100 & -0.59313400 & -1.96966900 \\ \mathrm{H} & 0.43423000 & -2.28622800 & -1.54376100 \\ \mathrm{C} & 9.02519100 & -0.09784200 & 0.70758000 \\ \mathrm{H} & 9.05627500 & -0.74758500 & 1.59194900 \\ \mathrm{H} & 9.99713200 & -0.17354400 & 0.20478100 \\ \mathrm{H} & 8.91251400 & 0.93552500 & 1.06075500\end{array}$

\section{${ }^{n} \mathrm{C}_{8} \mathrm{H}_{17}$ Bpin}

C

C

B

O

O

C

$\mathrm{H}$

$\mathrm{H}$

$\mathrm{H}$

C

$\mathrm{H}$

$\mathrm{H}$

$\mathrm{H}$

C

$\mathrm{H}$

$\mathrm{H}$

$\mathrm{H}$

C

$\mathrm{H}$

\begin{tabular}{lccc}
-3.72192800 & 0.84361200 & -0.36155700 \\
-3.99301300 & -0.36552300 & 0.62010700 \\
-1.93136300 & -0.59413200 & -0.36629000 \\
-2.67519200 & -0.98025600 & 0.72652000 \\
-2.56131200 & 0.37921000 & -1.11089700 \\
-4.46087500 & 0.02665600 & 2.02055200 \\
-5.42501200 & 0.54761300 & 1.97802200 \\
-4.58934300 & -0.87459900 & 2.62945800 \\
-3.73744500 & 0.67202700 & 2.52478900 \\
-4.92941100 & -1.43244500 & 0.03505700 \\
-4.91359500 & -2.31254300 & 0.68634700 \\
-5.96172700 & -1.07113100 & -0.03015600 \\
-4.60789900 & -1.74683400 & -0.96338900 \\
\hline-3.29687800 & 2.13259600 & 0.35595900 \\
-4.13022000 & 2.58024700 & 0.90882100 \\
-2.47411500 & 1.95106800 & 1.05514700 \\
-2.95141400 & 2.85556500 & -0.39037100 \\
-4.84847000 & 1.14443000 & -1.34851800 \\
-5.07927600 & 0.28100700 & -1.97703200 \\
\hline
\end{tabular}




\begin{tabular}{|c|c|c|c|}
\hline $\mathrm{H}$ & -5.76052600 & 1.44698900 & -0.81996200 \\
\hline $\mathrm{H}$ & -4.54887900 & 1.96819700 & -2.00521200 \\
\hline $\mathrm{C}$ & -0.50591200 & -1.16442700 & -0.70850300 \\
\hline $\mathrm{H}$ & -0.39310400 & -1.23336600 & -1.80029400 \\
\hline $\mathrm{H}$ & -0.40369200 & -2.18385600 & -0.31135000 \\
\hline $\mathrm{C}$ & 0.63854700 & -0.28604700 & -0.14660700 \\
\hline $\mathrm{H}$ & 0.53487200 & 0.73875600 & -0.53177500 \\
\hline $\mathrm{H}$ & 0.54251400 & -0.21556100 & 0.94694200 \\
\hline $\mathrm{C}$ & 2.03854800 & -0.81263100 & -0.49270300 \\
\hline $\mathrm{H}$ & 2.13694200 & -0.88024800 & -1.58694600 \\
\hline $\mathrm{H}$ & 2.14176000 & -1.84043200 & -0.11246700 \\
\hline $\mathrm{C}$ & 3.17477700 & 0.05381200 & 0.06798100 \\
\hline $\mathrm{H}$ & 3.07577500 & 0.11734900 & 1.16253400 \\
\hline $\mathrm{H}$ & 3.06491600 & 1.08272000 & -0.30783600 \\
\hline $\mathrm{C}$ & 4.57648200 & -0.46432400 & -0.28290800 \\
\hline $\mathrm{H}$ & 4.68703200 & -1.49368000 & 0.09127800 \\
\hline $\mathrm{H}$ & 4.67670600 & -0.52587700 & -1.37739300 \\
\hline $\mathrm{C}$ & 5.71111000 & 0.40249600 & 0.28048400 \\
\hline $\mathrm{H}$ & 5.61266400 & 0.46273000 & 1.37537300 \\
\hline $\mathrm{H}$ & 5.60010500 & 1.43264800 & -0.09185900 \\
\hline $\mathrm{C}$ & 7.11380800 & -0.11161400 & -0.07149700 \\
\hline $\mathrm{H}$ & 7.22622200 & -1.14059600 & 0.30065000 \\
\hline $\mathrm{H}$ & 7.21365400 & -0.17060300 & -1.16528400 \\
\hline $\mathrm{C}$ & 8.23984300 & 0.76094300 & 0.49628500 \\
\hline $\mathrm{H}$ & 8.18756400 & 0.81274900 & 1.59162100 \\
\hline $\mathrm{H}$ & 9.22733300 & 0.36560300 & 0.22861300 \\
\hline $\mathrm{H}$ & 8.17726800 & 1.78788600 & 0.11340400 \\
\hline
\end{tabular}

\section{-Bpin (INT2)}

C

$-0.78915600$

$-0.15344500$

0.04279100 


\begin{tabular}{lrrr} 
C & 0.78915600 & -0.15344500 & -0.04279100 \\
B & 0.00000000 & 1.98119200 & 0.00000000 \\
$\mathrm{O}$ & 1.08668300 & 1.25715600 & -0.37463700 \\
$\mathrm{O}$ & -1.08668300 & 1.25715600 & 0.37463700 \\
$\mathrm{C}$ & 1.48210100 & -0.43683600 & 1.29456300 \\
$\mathrm{H}$ & 1.36071000 & -1.48423600 & 1.59286000 \\
$\mathrm{H}$ & 2.55219200 & -0.23096300 & 1.19023900 \\
$\mathrm{H}$ & 1.09291200 & 0.20048900 & 2.09481500 \\
$\mathrm{C}$ & 1.38048200 & -1.03136700 & -1.14196300 \\
$\mathrm{H}$ & 1.14002300 & -2.08708800 & -0.96606700 \\
$\mathrm{H}$ & 1.01279000 & -0.74980600 & -2.13149700 \\
$\mathrm{H}$ & 2.47056800 & -0.92873800 & -1.14478600 \\
$\mathrm{C}$ & -1.48210100 & -0.43683600 & -1.29456300 \\
$\mathrm{H}$ & -1.09291200 & 0.20048900 & -2.09481500 \\
$\mathrm{H}$ & -1.36071000 & -1.48423600 & -1.59286000 \\
$\mathrm{H}$ & -2.55219200 & -0.23096300 & -1.19023900 \\
$\mathrm{C}$ & -1.38048200 & -1.03136700 & 1.14196300 \\
$\mathrm{H}$ & -1.01279000 & -0.74980600 & 2.13149700 \\
$\mathrm{H}$ & -2.47056900 & -0.92873800 & 1.14478600 \\
\hline & -1.14002300 & -2.08708800 & 0.96606700 \\
\hline
\end{tabular}

\section{${ }^{t} \mathrm{BuO}^{-}$}

C

$0.00014800 \quad 0.00012300 \quad-0.14922200$

C

$\begin{array}{lll}1.35992400 & -0.52824300 & 0.43633700\end{array}$

$\mathrm{H}$

$\begin{array}{lll}1.53403200 & -1.54747400 & 0.06435200\end{array}$

$\mathrm{H}$

$\begin{array}{lll}2.17648000 & 0.10637600 & 0.06483300\end{array}$

H

$\begin{array}{lll}1.39999300 & -0.54378600 & 1.54111900\end{array}$

C

$\begin{array}{lll}-1.13776700 & -0.91395500 & 0.43478300\end{array}$

$\mathrm{H}$

$\begin{array}{lll}-1.17346500 & -0.94046100 & 1.53955600\end{array}$

$\mathrm{H}$

$\begin{array}{lll}-2.10712400 & -0.55584300 & 0.06110500\end{array}$ 


$\begin{array}{lrrr}\mathrm{H} & -0.99554800 & -1.93853100 & 0.06390600 \\ \mathrm{C} & -0.22311200 & 1.44163800 & 0.43615000 \\ \mathrm{H} & 0.57356900 & 2.10196000 & 0.06631800 \\ \mathrm{H} & -1.17987500 & 1.83189800 & 0.06225600 \\ \mathrm{H} & -0.23219800 & 1.48323900 & 1.54089500 \\ \mathrm{O} & 0.00112200 & 0.00065500 & -1.49407900\end{array}$

TS3

C

C

B

$\mathrm{O}$

$\mathrm{O}$

C

$\mathrm{H}$

$\mathrm{H}$

$\mathrm{H}$

C

$\mathrm{H}$

$\mathrm{H}$

$\mathrm{H}$

C

$\mathrm{H}$

$\mathrm{H}$

$\mathrm{H}$

C

$\mathrm{H}$

$\mathrm{H}$

$\mathrm{H}$

$\mathrm{O}$
1.89872600

1.88876700

0.89370400

1.28796300

1.30229900

3.27799100

3.80276800

3.15886200

3.90456200

0.99786700

1.01573000

1.37464100

$-0.03996500$

3.29606500

3.81861900

3.91783700

3.19065700

1.01592100

$-0.02627700$

1.38976300

1.04803600

$-1.61882700$
0.80101300

$-0.80302900$

0.00739200

$-1.14693700$

1.15538200

$-1.45253900$

$-1.25502300$

$-2.53720800$

$-1.10657600$

$-1.43019800$

$-2.52086900$

$-1.19847900$

$-1.08196000$

1.43299200

1.22673700

1.08077000

2.51927600

1.43714200

1.10304400

1.19811100

2.52775600

0.02081900

61
1.10146200

0.13039500

0.12866000

$-1.76636500$

$-1.17122700$

$-1.16862200$

0.13988200

1.08353800

0.03928500

$-0.68839800$

1.20340100

1.07899500

2.20919300

1.09824000

0.14277600

1.08578900

$-0.68647800$

0.04446800

1.20662200

2.21177600

1.08477600

0.34370800 


$\begin{array}{lrrr}\mathrm{C} & -2.94312300 & 0.00277200 & 0.03319900 \\ \mathrm{C} & -3.82088700 & -0.13513300 & 1.32020500 \\ \mathrm{H} & -3.55119500 & -1.06221700 & 1.84429100 \\ \mathrm{H} & -3.60628400 & 0.70509200 & 1.99459800 \\ \mathrm{H} & -4.90517300 & -0.15177100 & 1.11332600 \\ \mathrm{C} & -3.37326000 & 1.31640800 & -0.69500500 \\ \mathrm{H} & -2.77803500 & 1.43163200 & -1.61019400 \\ \mathrm{H} & -4.44357000 & 1.33926200 & -0.96486100 \\ \mathrm{H} & -3.15793000 & 2.17667500 & -0.04667000 \\ \mathrm{C} & -3.28755700 & -1.19685200 & -0.90623600 \\ \mathrm{H} & -2.68886200 & -1.11821600 & -1.82302000 \\ \mathrm{H} & -3.01222100 & -2.13665500 & -0.40870000 \\ \mathrm{H} & -4.35502000 & -1.24590800 & -1.18385600\end{array}$

INT3

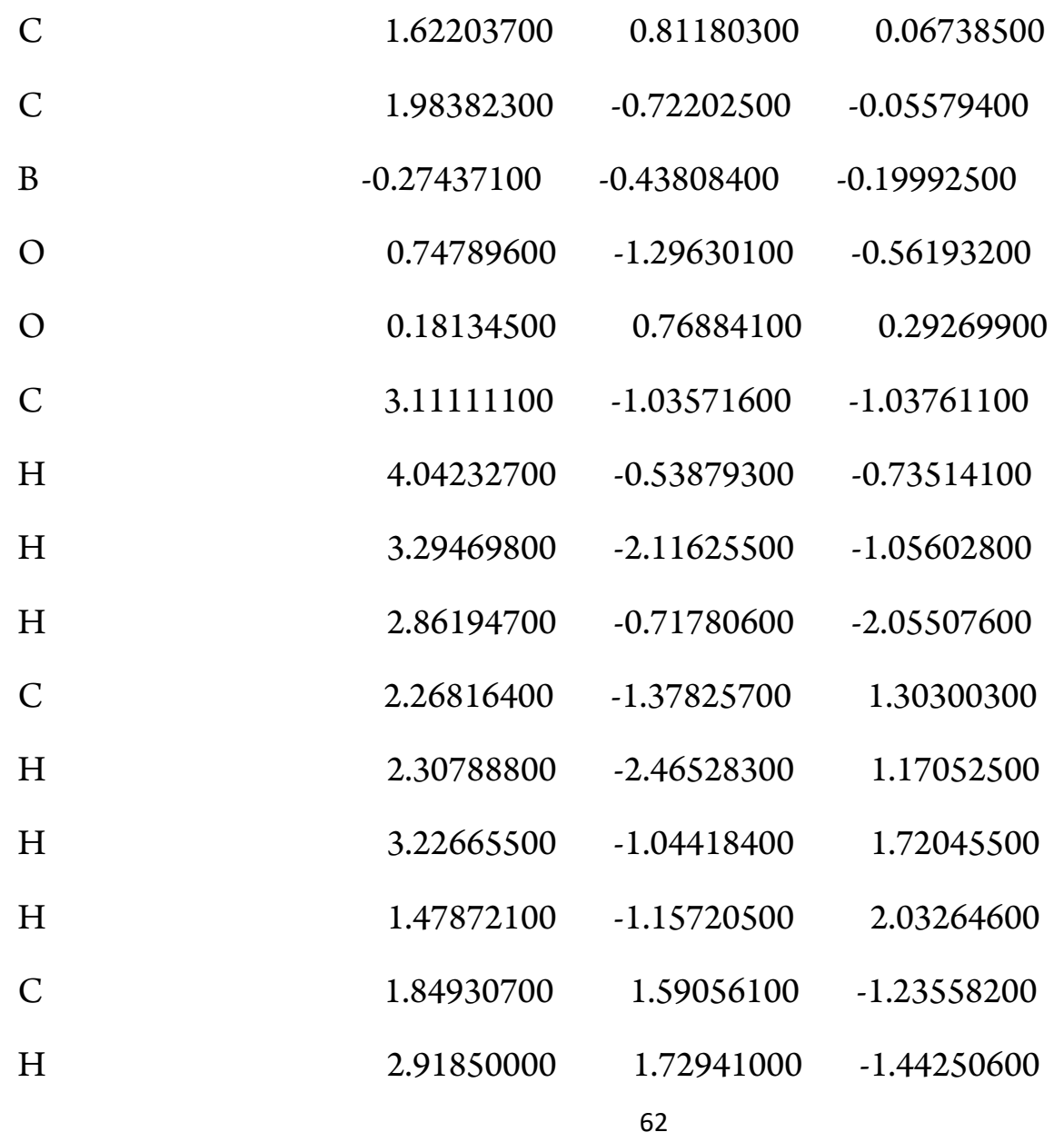




\begin{tabular}{|c|c|c|c|}
\hline $\mathrm{H}$ & 1.39182600 & 1.08445800 & -2.09550000 \\
\hline $\mathrm{H}$ & 1.38768100 & 2.58008200 & -1.14430500 \\
\hline $\mathrm{C}$ & 2.27207500 & 1.53910500 & 1.24221100 \\
\hline $\mathrm{H}$ & 1.99645100 & 1.08978500 & 2.20218400 \\
\hline $\mathrm{H}$ & 3.36718300 & 1.53072800 & 1.15196600 \\
\hline $\mathrm{H}$ & 1.94336800 & 2.58450300 & 1.25476700 \\
\hline $\mathrm{O}$ & -1.57036600 & -0.81997000 & -0.33569300 \\
\hline $\mathrm{C}$ & -2.74089900 & -0.03424200 & 0.00457800 \\
\hline $\mathrm{C}$ & -2.78426500 & 1.24321700 & -0.84582000 \\
\hline $\mathrm{H}$ & -1.94869600 & 1.90744100 & -0.60445100 \\
\hline $\mathrm{H}$ & -2.73257700 & 0.99245800 & -1.91308700 \\
\hline $\mathrm{H}$ & -3.72144100 & 1.78730700 & -0.66539900 \\
\hline $\mathrm{C}$ & -3.92497000 & -0.94595700 & -0.34029000 \\
\hline $\mathrm{H}$ & -3.86988400 & -1.87608800 & 0.23813600 \\
\hline $\mathrm{H}$ & -4.87510400 & -0.44695000 & -0.11204600 \\
\hline $\mathrm{H}$ & -3.91008800 & -1.20329600 & -1.40643800 \\
\hline $\mathrm{C}$ & -2.73182400 & 0.28936600 & 1.50561200 \\
\hline $\mathrm{H}$ & -2.64251200 & -0.63341400 & 2.09292500 \\
\hline $\mathrm{H}$ & -1.89611200 & 0.94650300 & 1.76615500 \\
\hline $\mathrm{H}$ & -3.66733200 & 0.78933600 & 1.79310400 \\
\hline
\end{tabular}

\section{${ }^{n} \mathrm{C}_{8} \mathrm{H}_{17} \mathrm{I}$}

C

$\mathrm{H}$

$\mathrm{H}$

$\mathrm{H}$

C

$\mathrm{H}$

$\mathrm{H}$

C
$-7.25682500$

$-8.19560300$

$-7.25943100$

$-7.25942900$

$-6.03915600$

$-6.08336200$

$-6.08336300$

$-4.70076000$
$-0.58120500 \quad 0.00000000$

$-0.01413100 \quad-0.00000300$

$-1.23005700 \quad 0.88547400$

$-1.23006500 \quad-0.88546800$

$0.35108000 \quad-0.00000200$

$1.01076300 \quad-0.87903100$

$1.01076900 \quad 0.87902200$

$-0.40107200 \quad 0.00000100$ 


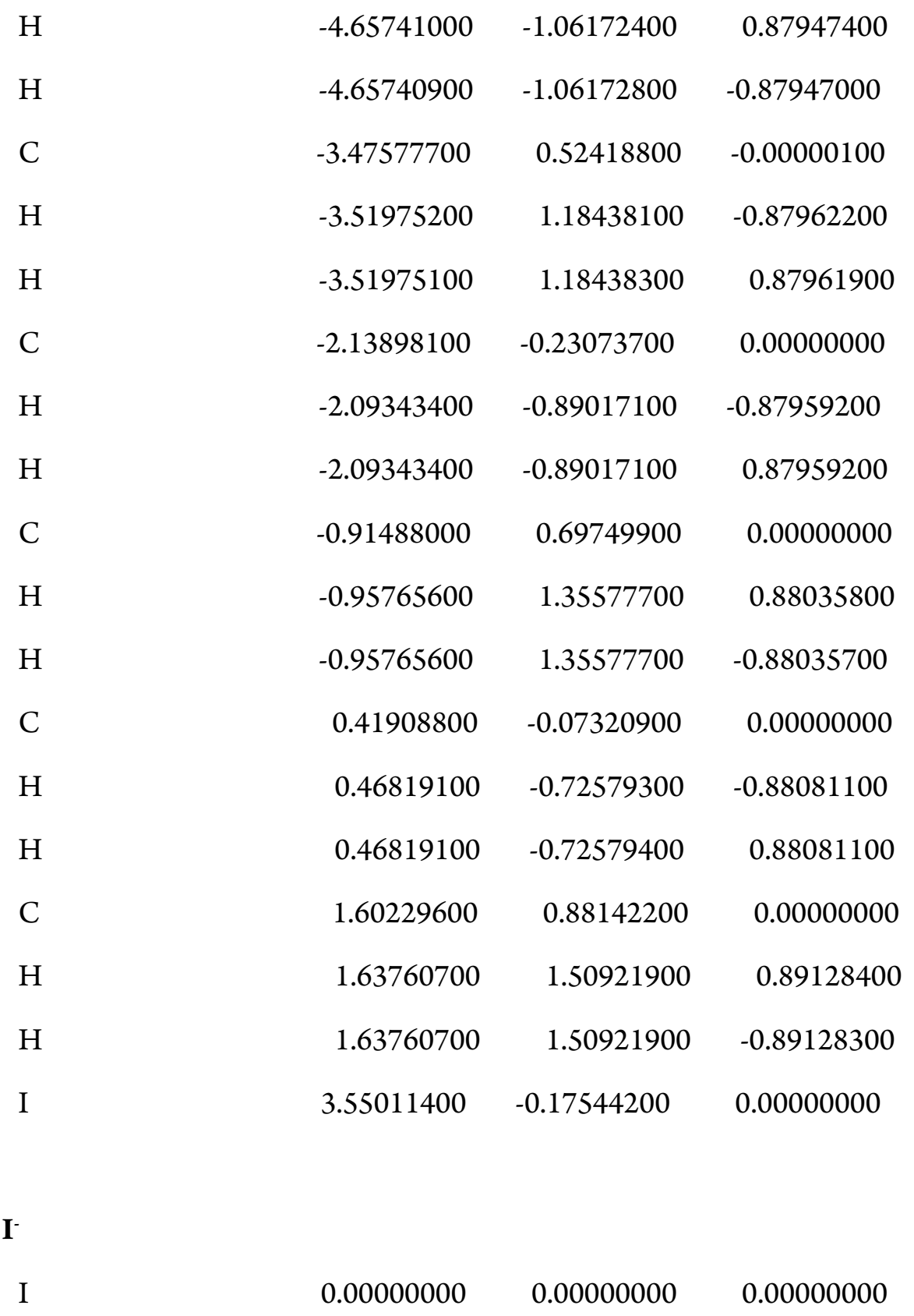

\section{${ }^{t}$ BuOBpin}

$\begin{array}{lrcr}\text { C } & 1.62306900 & 0.81371800 & 0.06543800 \\ \text { C } & 1.99037200 & -0.71924500 & -0.05402200 \\ \text { B } & -0.27464900 & -0.44700200 & -0.16658000 \\ \text { O } & 0.74895500 & -1.29880800 & -0.53451200 \\ \text { O } & 0.18845900 & 0.76555600 & 0.31875400 \\ \text { C } & 3.09794200 & -1.04273000 & -1.05560000 \\ \mathrm{H} & 4.04070400 & -0.56386400 & -0.76450500 \\ & & 64 & \end{array}$




\begin{tabular}{|c|c|c|c|}
\hline $\mathrm{H}$ & 3.26161200 & -2.12532200 & -1.08225200 \\
\hline $\mathrm{H}$ & 2.83722300 & -0.71823000 & -2.06587200 \\
\hline $\mathrm{C}$ & 2.30042500 & -1.37547100 & 1.29950200 \\
\hline $\mathrm{H}$ & 2.34809100 & -2.46065400 & 1.16229100 \\
\hline $\mathrm{H}$ & 3.26081400 & -1.03609000 & 1.70349800 \\
\hline $\mathrm{H}$ & 1.51952200 & -1.16323800 & 2.03742500 \\
\hline $\mathrm{C}$ & 1.82142900 & 1.58919400 & -1.24456400 \\
\hline $\mathrm{H}$ & 2.88392200 & 1.72116500 & -1.47723600 \\
\hline $\mathrm{H}$ & 1.34357800 & 1.08127700 & -2.08891600 \\
\hline $\mathrm{H}$ & 1.36719800 & 2.58062100 & -1.14412900 \\
\hline $\mathrm{C}$ & 2.29401800 & 1.55607700 & 1.21956200 \\
\hline $\mathrm{H}$ & 2.04975000 & 1.10841300 & 2.18604500 \\
\hline $\mathrm{H}$ & 3.38411400 & 1.55759500 & 1.09986500 \\
\hline $\mathrm{H}$ & 1.95416300 & 2.59737400 & 1.23414200 \\
\hline $\mathrm{O}$ & -1.56766500 & -0.82818900 & -0.29067800 \\
\hline $\mathrm{C}$ & -2.74918000 & -0.03565600 & 0.00403700 \\
\hline $\mathrm{C}$ & -2.77221300 & 1.21543800 & -0.88452800 \\
\hline $\mathrm{H}$ & -1.93030900 & 1.87560100 & -0.65656900 \\
\hline $\mathrm{H}$ & -2.72146200 & 0.93220200 & -1.94226700 \\
\hline $\mathrm{H}$ & -3.70172800 & 1.77478200 & -0.72520500 \\
\hline $\mathrm{C}$ & -3.92548700 & -0.95810700 & -0.33353100 \\
\hline $\mathrm{H}$ & -3.88220800 & -1.86960600 & 0.27255500 \\
\hline $\mathrm{H}$ & -4.87931200 & -0.45424300 & -0.13903900 \\
\hline $\mathrm{H}$ & -3.89276300 & -1.24888400 & -1.38920900 \\
\hline $\mathrm{C}$ & -2.76434600 & 0.33407100 & 1.49389000 \\
\hline $\mathrm{H}$ & -2.70816600 & -0.57044000 & 2.11061800 \\
\hline $\mathrm{H}$ & -1.92212500 & 0.98449400 & 1.74815500 \\
\hline $\mathrm{H}$ & -3.69356500 & 0.85985900 & 1.74389700 \\
\hline
\end{tabular}

\section{Ate complex}




\begin{tabular}{|c|c|c|c|}
\hline $\mathrm{C}$ & -3.12921700 & -0.11355800 & -0.64587300 \\
\hline $\mathrm{C}$ & -2.93345800 & -0.80583700 & 0.75284500 \\
\hline $\mathrm{C}$ & 2.65186700 & -1.06365300 & 0.62654600 \\
\hline $\mathrm{C}$ & 2.11279200 & -1.72251400 & -0.70416000 \\
\hline B & -0.89102200 & 0.01603000 & -0.01510400 \\
\hline B & 0.83637400 & 0.23639500 & -0.18901500 \\
\hline $\mathrm{O}$ & 1.30683200 & -0.70486300 & -1.26567400 \\
\hline $\mathrm{O}$ & -1.49937300 & -0.91449000 & 0.84207300 \\
\hline $\mathrm{O}$ & -1.89307000 & 0.61331900 & -0.79936400 \\
\hline $\mathrm{O}$ & 1.56238700 & -0.25828000 & 1.03422000 \\
\hline $\mathrm{C}$ & -3.39836500 & 0.06442300 & 1.93384300 \\
\hline $\mathrm{H}$ & -4.49200900 & 0.14880100 & 1.97848500 \\
\hline $\mathrm{H}$ & -3.04654500 & -0.39243600 & 2.86547900 \\
\hline $\mathrm{H}$ & -2.97051600 & 1.07029600 & 1.87430100 \\
\hline $\mathrm{C}$ & -3.54142400 & -2.20539200 & 0.88136700 \\
\hline $\mathrm{H}$ & -4.63302100 & -2.17905400 & 0.75986700 \\
\hline $\mathrm{H}$ & -3.12218200 & -2.89334100 & 0.14249700 \\
\hline $\mathrm{H}$ & -3.31911400 & -2.60818100 & 1.87643000 \\
\hline $\mathrm{C}$ & -3.21289100 & -1.11355000 & -1.81248100 \\
\hline $\mathrm{H}$ & -2.37615500 & -1.81840600 & -1.78546400 \\
\hline $\mathrm{H}$ & -4.15446200 & -1.67817000 & -1.80429400 \\
\hline $\mathrm{H}$ & -3.14796700 & -0.55831300 & -2.75474600 \\
\hline $\mathrm{C}$ & -4.29758800 & 0.87193000 & -0.73103000 \\
\hline $\mathrm{H}$ & -4.19594800 & 1.68039800 & -0.00215600 \\
\hline $\mathrm{H}$ & -4.32250400 & 1.32289000 & -1.72989500 \\
\hline $\mathrm{H}$ & -5.25733800 & 0.36496400 & -0.56162900 \\
\hline $\mathrm{C}$ & 3.20159500 & -2.10859400 & -1.71815700 \\
\hline $\mathrm{H}$ & 3.90547400 & -2.84215700 & -1.29807000 \\
\hline $\mathrm{H}$ & 2.73364800 & -2.55601300 & -2.60494100 \\
\hline $\mathrm{H}$ & 3.76243800 & -1.22913200 & -2.04668700 \\
\hline
\end{tabular}




\begin{tabular}{|c|c|c|c|}
\hline $\mathrm{C}$ & 1.23571100 & -2.96514100 & -0.42324800 \\
\hline $\mathrm{H}$ & 0.73463700 & -3.25183800 & -1.35688000 \\
\hline $\mathrm{H}$ & 1.82361300 & -3.82508300 & -0.07093900 \\
\hline $\mathrm{H}$ & 0.46600300 & -2.73349800 & 0.31888200 \\
\hline $\mathrm{C}$ & 3.89421500 & -0.17646000 & 0.37508800 \\
\hline $\mathrm{H}$ & 4.78978300 & -0.76802600 & 0.13389900 \\
\hline $\mathrm{H}$ & 3.69789600 & 0.53394300 & -0.43195500 \\
\hline $\mathrm{H}$ & 4.09875200 & 0.39828900 & 1.28751000 \\
\hline $\mathrm{C}$ & 2.97955900 & -2.05982400 & 1.74968600 \\
\hline $\mathrm{H}$ & 2.08914000 & -2.61672100 & 2.05569100 \\
\hline $\mathrm{H}$ & 3.75755900 & -2.77435500 & 1.44292300 \\
\hline $\mathrm{H}$ & 3.34877200 & -1.51277500 & 2.62713600 \\
\hline $\mathrm{O}$ & 1.29954900 & 1.58447200 & -0.62102800 \\
\hline $\mathrm{C}$ & 0.99713200 & 2.82563900 & -0.02510600 \\
\hline $\mathrm{C}$ & 2.28524700 & 3.67384500 & -0.11093900 \\
\hline $\mathrm{H}$ & 2.12271700 & 4.69957100 & 0.25285700 \\
\hline $\mathrm{H}$ & 3.08122400 & 3.21215300 & 0.48551600 \\
\hline $\mathrm{H}$ & 2.62624700 & 3.71954100 & -1.15252100 \\
\hline $\mathrm{C}$ & -0.11884500 & 3.52679500 & -0.83423800 \\
\hline $\mathrm{H}$ & 0.20419500 & 3.64792500 & -1.87615800 \\
\hline $\mathrm{H}$ & -1.02657800 & 2.91624100 & -0.83445400 \\
\hline $\mathrm{H}$ & -0.35467400 & 4.52104000 & -0.42363900 \\
\hline $\mathrm{C}$ & 0.57786900 & 2.72119200 & 1.45919000 \\
\hline $\mathrm{H}$ & 0.47871700 & 3.72449800 & 1.89960800 \\
\hline $\mathrm{H}$ & -0.38420100 & 2.20841100 & 1.56743600 \\
\hline $\mathrm{H}$ & 1.31983900 & 2.14933500 & 2.02468200 \\
\hline
\end{tabular}

\section{TS4}

C

$0.66428800 \quad-2.57174700 \quad 1.27650800$

C

$\begin{array}{lll}1.66923200 & -1.77035700 & 2.19708500\end{array}$ 


\begin{tabular}{|c|c|c|c|}
\hline $\mathrm{C}$ & 1.42389600 & 3.00210700 & 0.87358900 \\
\hline $\mathrm{C}$ & 2.67459000 & 2.88589700 & -0.07852700 \\
\hline B & 1.71011700 & -0.89839900 & -0.03423200 \\
\hline B & 1.47703100 & 0.89212200 & -0.14723200 \\
\hline $\mathrm{O}$ & 2.35655700 & 1.72898700 & -0.87017300 \\
\hline $\mathrm{O}$ & 2.44810000 & -1.04180800 & 1.26520200 \\
\hline $\mathrm{O}$ & 0.46218700 & -1.68311900 & 0.18649500 \\
\hline $\mathrm{O}$ & 0.94951200 & 1.64626800 & 0.92577300 \\
\hline $\mathrm{C}$ & 0.94326900 & -0.79170000 & 3.14607800 \\
\hline $\mathrm{H}$ & 0.38442600 & -1.31809100 & 3.93298500 \\
\hline $\mathrm{H}$ & 1.69257700 & -0.15090200 & 3.62717800 \\
\hline $\mathrm{H}$ & 0.26335000 & -0.14034500 & 2.59224000 \\
\hline $\mathrm{C}$ & 2.61216600 & -2.65131000 & 3.03484900 \\
\hline $\mathrm{H}$ & 2.05547600 & -3.29587500 & 3.73109500 \\
\hline $\mathrm{H}$ & 3.24007300 & -3.27930200 & 2.39661900 \\
\hline $\mathrm{H}$ & 3.27600900 & -2.00809300 & 3.62651500 \\
\hline $\mathrm{C}$ & 1.27183100 & -3.89641700 & 0.76308800 \\
\hline $\mathrm{H}$ & 2.24791400 & -3.71750000 & 0.30472800 \\
\hline $\mathrm{H}$ & 1.37764700 & -4.64179000 & 1.56416300 \\
\hline $\mathrm{H}$ & 0.60667400 & -4.31174500 & -0.00413400 \\
\hline $\mathrm{C}$ & -0.69585600 & -2.87624100 & 1.92134300 \\
\hline $\mathrm{H}$ & -1.21922000 & -1.95681900 & 2.19905500 \\
\hline $\mathrm{H}$ & -1.32635700 & -3.42076400 & 1.20640500 \\
\hline $\mathrm{H}$ & -0.58352400 & -3.50113500 & 2.81875100 \\
\hline $\mathrm{C}$ & 2.89947800 & 4.08065100 & -1.01048500 \\
\hline $\mathrm{H}$ & 3.09831200 & 4.99818100 & -0.43973800 \\
\hline $\mathrm{H}$ & 3.76763000 & 3.88348900 & -1.65016400 \\
\hline $\mathrm{H}$ & 2.03759900 & 4.25403000 & -1.66093600 \\
\hline $\mathrm{C}$ & 3.98044100 & 2.56800200 & 0.67372700 \\
\hline \multirow[t]{2}{*}{$\mathrm{H}$} & 4.75675200 & 2.32971900 & -0.06197600 \\
\hline & & 6 & \\
\hline
\end{tabular}




\begin{tabular}{|c|c|c|c|}
\hline $\mathrm{H}$ & 4.32460300 & 3.41631000 & 1.28003400 \\
\hline $\mathrm{H}$ & 3.85639700 & 1.69082200 & 1.31604100 \\
\hline $\mathrm{C}$ & 0.29972300 & 3.88757000 & 0.30478900 \\
\hline $\mathrm{H}$ & 0.57620100 & 4.95016800 & 0.31064800 \\
\hline $\mathrm{H}$ & 0.04121600 & 3.60117800 & -0.71818700 \\
\hline $\mathrm{H}$ & -0.59487300 & 3.76291700 & 0.92537100 \\
\hline $\mathrm{C}$ & 1.73964500 & 3.46112500 & 2.30205500 \\
\hline $\mathrm{H}$ & 2.42903500 & 2.77387400 & 2.79814300 \\
\hline $\mathrm{H}$ & 2.17739500 & 4.46892100 & 2.30909400 \\
\hline $\mathrm{H}$ & 0.81434200 & 3.48836300 & 2.88990600 \\
\hline $\mathrm{C}$ & -1.72134000 & 0.67889000 & -0.56841300 \\
\hline $\mathrm{H}$ & -1.74204400 & 1.54507000 & 0.10643400 \\
\hline $\mathrm{H}$ & -1.54371700 & -0.20723800 & 0.05393400 \\
\hline $\mathrm{C}$ & -3.10521800 & 0.54870900 & -1.25074000 \\
\hline $\mathrm{H}$ & -3.09647200 & -0.32443600 & -1.92001500 \\
\hline $\mathrm{H}$ & -3.28491500 & 1.42661900 & -1.89120900 \\
\hline $\mathrm{C}$ & -4.25801000 & 0.40776300 & -0.24526500 \\
\hline $\mathrm{H}$ & -4.07401600 & -0.47179700 & 0.38958300 \\
\hline $\mathrm{H}$ & -4.25589000 & 1.27672200 & 0.43124600 \\
\hline $\mathrm{C}$ & -5.64132500 & 0.28145200 & -0.89902800 \\
\hline $\mathrm{H}$ & -5.64445300 & -0.58652900 & -1.57638200 \\
\hline $\mathrm{H}$ & -5.82573500 & 1.16291700 & -1.53319200 \\
\hline $\mathrm{C}$ & -6.78975100 & 0.13772300 & 0.10998000 \\
\hline $\mathrm{H}$ & -6.60882300 & -0.74627500 & 0.74066100 \\
\hline $\mathrm{H}$ & -6.78420800 & 1.00270200 & 0.79146100 \\
\hline $\mathrm{C}$ & -8.17548400 & 0.01812700 & -0.53941500 \\
\hline $\mathrm{H}$ & -8.35824900 & 0.90249600 & -1.16797800 \\
\hline $\mathrm{H}$ & -8.18264700 & -0.84589000 & -1.22033700 \\
\hline $\mathrm{C}$ & -0.58127000 & 0.80185600 & -1.53103800 \\
\hline \multirow[t]{2}{*}{$\mathrm{H}$} & -0.35376300 & -0.06194500 & -2.14673100 \\
\hline & & 69 & \\
\hline
\end{tabular}




\begin{tabular}{|c|c|c|c|}
\hline $\mathrm{H}$ & -0.37234000 & 1.76613900 & -1.99362100 \\
\hline $\mathrm{C}$ & -9.31407000 & -0.12623800 & 0.47848200 \\
\hline $\mathrm{H}$ & -9.35206700 & 0.73848800 & 1.15415500 \\
\hline $\mathrm{H}$ & -10.29066100 & -0.20647300 & -0.01616800 \\
\hline $\mathrm{H}$ & -9.17929000 & -1.02249700 & 1.09818600 \\
\hline $\mathrm{O}$ & 2.63705800 & -1.47055100 & -1.03968800 \\
\hline $\mathrm{C}$ & 2.52396400 & -1.69310300 & -2.42492800 \\
\hline $\mathrm{C}$ & 1.26570600 & -2.51116900 & -2.79542600 \\
\hline $\mathrm{H}$ & 1.22722700 & -2.69151000 & -3.87994900 \\
\hline $\mathrm{H}$ & 1.27713800 & -3.47883000 & -2.28202300 \\
\hline $\mathrm{H}$ & 0.35165000 & -1.99481100 & -2.49223700 \\
\hline $\mathrm{C}$ & 3.77306200 & -2.51968100 & -2.80348900 \\
\hline $\mathrm{H}$ & 3.78296200 & -3.46262400 & -2.24346800 \\
\hline $\mathrm{H}$ & 3.79688900 & -2.74784100 & -3.87890400 \\
\hline $\mathrm{H}$ & 4.67980500 & -1.96174400 & -2.54049300 \\
\hline $\mathrm{C}$ & 2.55310500 & -0.37764800 & -3.23536100 \\
\hline $\mathrm{H}$ & 1.68105300 & 0.24481100 & -3.02516600 \\
\hline $\mathrm{H}$ & 3.43977600 & 0.20577000 & -2.96704600 \\
\hline $\mathrm{H}$ & 2.57765900 & -0.58929800 & -4.31487600 \\
\hline
\end{tabular}

\section{TS5}

$\begin{array}{llrr}\text { C } & -0.92577700 & -2.38672500 & -1.97799900 \\ \text { C } & -2.46952900 & -2.03983000 & -1.87991700 \\ \text { C } & -1.42482500 & 3.25176400 & -0.84069100 \\ \text { C } & -2.46712200 & 2.76426100 & 0.24642500 \\ \text { B } & -1.22196400 & -0.45286800 & -0.73212300 \\ \text { B } & -0.75135100 & 1.13255500 & 0.01795000 \\ \text { O } & -1.77645500 & 1.71177400 & 0.90715800 \\ \text { O } & -2.46000100 & -0.70706400 & -1.30915100 \\ \text { O } & -0.32010700 & -1.45075500 & -1.05807400\end{array}$




\begin{tabular}{|c|c|c|c|}
\hline $\mathrm{O}$ & -0.67354300 & 2.07842100 & -1.12775500 \\
\hline $\mathrm{C}$ & -3.20222900 & -1.97450700 & -3.22434300 \\
\hline $\mathrm{H}$ & -3.20534800 & -2.95428900 & -3.72041500 \\
\hline $\mathrm{H}$ & -4.24361900 & -1.67885300 & -3.05252500 \\
\hline $\mathrm{H}$ & -2.75305400 & -1.24143200 & -3.89997500 \\
\hline $\mathrm{C}$ & -3.24835400 & -2.94025900 & -0.91047400 \\
\hline $\mathrm{H}$ & -3.30393000 & -3.97450100 & -1.27526400 \\
\hline $\mathrm{H}$ & -2.79431200 & -2.91949400 & 0.08508900 \\
\hline $\mathrm{H}$ & -4.27114400 & -2.55397300 & -0.82224300 \\
\hline $\mathrm{C}$ & -0.55514200 & -3.80034900 & -1.52090900 \\
\hline $\mathrm{H}$ & -0.84408900 & -3.96112600 & -0.47965200 \\
\hline $\mathrm{H}$ & -1.03405600 & -4.56218400 & -2.15072500 \\
\hline $\mathrm{H}$ & 0.53097700 & -3.93081000 & -1.59448800 \\
\hline $\mathrm{C}$ & -0.31092800 & -2.10647200 & -3.35962300 \\
\hline $\mathrm{H}$ & -0.50787100 & -1.07851200 & -3.68020800 \\
\hline $\mathrm{H}$ & 0.77574100 & -2.23101200 & -3.29241200 \\
\hline $\mathrm{H}$ & -0.69082500 & -2.79497500 & -4.12543900 \\
\hline $\mathrm{C}$ & -2.84442500 & 3.82837900 & 1.28913800 \\
\hline $\mathrm{H}$ & -3.32140900 & 4.70007600 & 0.81937200 \\
\hline $\mathrm{H}$ & -3.55482700 & 3.39766700 & 2.00510400 \\
\hline $\mathrm{H}$ & -1.96957200 & 4.16710700 & 1.85121900 \\
\hline $\mathrm{C}$ & -3.76332500 & 2.20405200 & -0.37558600 \\
\hline $\mathrm{H}$ & -4.36090200 & 1.74360600 & 0.42003200 \\
\hline $\mathrm{H}$ & -4.36654900 & 2.99373400 & -0.84440600 \\
\hline $\mathrm{H}$ & -3.54483000 & 1.42816900 & -1.11251200 \\
\hline $\mathrm{C}$ & -0.45202800 & 4.32080800 & -0.29497900 \\
\hline $\mathrm{H}$ & -0.94912800 & 5.28559200 & -0.12346600 \\
\hline $\mathrm{H}$ & 0.00621500 & 3.99153400 & 0.64226800 \\
\hline $\mathrm{H}$ & 0.34931800 & 4.47136000 & -1.02812400 \\
\hline $\mathrm{C}$ & -2.04965100 & 3.77206600 & -2.14284500 \\
\hline
\end{tabular}




\begin{tabular}{|c|c|c|c|}
\hline $\mathrm{H}$ & -2.65033500 & 2.99883600 & -2.62936400 \\
\hline $\mathrm{H}$ & -2.68515700 & 4.65017800 & -1.96149100 \\
\hline $\mathrm{H}$ & -1.25276000 & 4.06633100 & -2.83741100 \\
\hline $\mathrm{C}$ & 1.92791700 & 0.68615700 & -0.04821900 \\
\hline $\mathrm{H}$ & 2.02436000 & 1.49034500 & -0.79368500 \\
\hline $\mathrm{H}$ & 1.78841100 & -0.24423900 & -0.61349000 \\
\hline $\mathrm{C}$ & 3.23734700 & 0.58816700 & 0.75321200 \\
\hline $\mathrm{H}$ & 3.13266100 & -0.19824400 & 1.51703500 \\
\hline $\mathrm{H}$ & 3.40040900 & 1.52831400 & 1.30505600 \\
\hline $\mathrm{C}$ & 4.47208500 & 0.28876300 & -0.10975800 \\
\hline $\mathrm{H}$ & 4.30930300 & -0.65458600 & -0.65376600 \\
\hline $\mathrm{H}$ & 4.57510400 & 1.06920200 & -0.88036900 \\
\hline $\mathrm{C}$ & 5.78129900 & 0.19089500 & 0.68656000 \\
\hline $\mathrm{H}$ & 5.67321500 & -0.58010200 & 1.46529200 \\
\hline $\mathrm{H}$ & 5.95330400 & 1.13889200 & 1.22026500 \\
\hline $\mathrm{C}$ & 7.01011900 & -0.13296600 & -0.17477500 \\
\hline $\mathrm{H}$ & 6.83934100 & -1.08194400 & -0.70667400 \\
\hline $\mathrm{H}$ & 7.12033100 & 0.63619900 & -0.95534000 \\
\hline $\mathrm{C}$ & 8.31871200 & -0.23214000 & 0.62164500 \\
\hline $\mathrm{H}$ & 8.49369800 & 0.71691400 & 1.15006000 \\
\hline $\mathrm{H}$ & 8.20873700 & -0.99893900 & 1.40281400 \\
\hline $\mathrm{C}$ & 0.68919300 & 0.94137900 & 0.81914800 \\
\hline $\mathrm{H}$ & 0.57182700 & 0.12302700 & 1.54361700 \\
\hline $\mathrm{H}$ & 0.84217500 & 1.86686500 & 1.40427000 \\
\hline $\mathrm{C}$ & 9.53856900 & -0.56309200 & -0.24750600 \\
\hline $\mathrm{H}$ & 9.69576700 & 0.20373200 & -1.01774700 \\
\hline $\mathrm{H}$ & 10.45639200 & -0.62742300 & 0.35125100 \\
\hline $\mathrm{H}$ & 9.40809700 & -1.52427500 & -0.76219100 \\
\hline $\mathrm{O}$ & -1.62405700 & -2.10110900 & 1.87033000 \\
\hline \multirow[t]{2}{*}{ C } & -2.24148600 & -1.69643100 & 3.03731200 \\
\hline & & 72 & \\
\hline
\end{tabular}




$\begin{array}{llll}\mathrm{C} & -1.30791200 & -0.78996200 & 3.87702100 \\ \mathrm{H} & -1.76270300 & -0.52350400 & 4.84285900 \\ \mathrm{H} & -0.35847500 & -1.30630100 & 4.06437200 \\ \mathrm{H} & -1.09678300 & 0.13202300 & 3.32647200 \\ \mathrm{C} & -2.54976100 & -2.99195300 & 3.84597800 \\ \mathrm{H} & -1.61926900 & -3.52779900 & 4.06713000 \\ \mathrm{H} & -3.05188800 & -2.74535100 & 4.79252000 \\ \mathrm{H} & -3.20107900 & -3.65361800 & 3.26298500 \\ \mathrm{C} & -3.56331300 & -0.94967000 & 2.73563300 \\ \mathrm{H} & -3.34569500 & -0.06962200 & 2.12243000 \\ \mathrm{H} & -4.24656200 & -1.60186600 & 2.17739200 \\ \mathrm{H} & -4.06593800 & -0.62331200 & 3.65858900\end{array}$

\section{INT4}

\begin{tabular}{lrrr} 
C & -0.51438600 & -2.59577600 & -1.31606000 \\
C & -1.60430500 & -1.78551600 & -2.12402100 \\
C & -2.06528600 & 2.81096800 & -0.99058800 \\
C & -2.94843900 & 2.47852100 & 0.27914100 \\
B & -1.55361100 & -1.06882300 & 0.11516700 \\
B & -0.97252600 & 1.22363400 & 0.34960500 \\
O & -2.01379200 & 1.82849700 & 1.14157700 \\
O & -2.35274900 & -1.14858600 & -1.08942700 \\
O & -0.32086400 & -1.79069800 & -0.14893300 \\
O & -1.07113900 & 1.78389800 & -0.97847000 \\
C & -0.99146900 & -0.71967500 & -3.05086900 \\
$\mathrm{H}$ & -0.45523400 & -1.17666300 & -3.89399500 \\
$\mathrm{H}$ & -1.79910300 & -0.09904800 & -3.45437600 \\
$\mathrm{H}$ & -0.32000900 & -0.05421900 & -2.50552500 \\
$\mathrm{C}$ & -2.56766800 & -2.65715600 & -2.94435700 \\
$\mathrm{H}$ & -2.03309900 & -3.23257200 & -3.71364900 \\
& & 73 & \\
\hline & & & \\
\hline & & & \\
\hline
\end{tabular}




\begin{tabular}{|c|c|c|c|}
\hline $\mathrm{H}$ & -3.12292800 & -3.35093400 & -2.30722200 \\
\hline $\mathrm{H}$ & -3.29622500 & -2.01187400 & -3.45005600 \\
\hline $\mathrm{C}$ & -1.02003800 & -3.98268200 & -0.86618400 \\
\hline $\mathrm{H}$ & -1.98010100 & -3.89756800 & -0.34797200 \\
\hline $\mathrm{H}$ & -1.13354900 & -4.67630000 & -1.71075000 \\
\hline $\mathrm{H}$ & -0.29325000 & -4.41218600 & -0.16624000 \\
\hline $\mathrm{C}$ & 0.83045500 & -2.76438400 & -2.03180500 \\
\hline $\mathrm{H}$ & 1.28593700 & -1.79712700 & -2.25843000 \\
\hline $\mathrm{H}$ & 1.52230700 & -3.31963300 & -1.38603300 \\
\hline $\mathrm{H}$ & 0.71530400 & -3.32689100 & -2.96875300 \\
\hline $\mathrm{C}$ & -3.50189300 & 3.70870400 & 1.01278200 \\
\hline $\mathrm{H}$ & -4.16987900 & 4.29392500 & 0.36531800 \\
\hline $\mathrm{H}$ & -4.07976700 & 3.37881300 & 1.88460100 \\
\hline $\mathrm{H}$ & -2.69988300 & 4.36048600 & 1.37082400 \\
\hline $\mathrm{C}$ & -4.11212700 & 1.51653300 & -0.02556900 \\
\hline $\mathrm{H}$ & -4.55309400 & 1.19353500 & 0.92448800 \\
\hline $\mathrm{H}$ & -4.89555400 & 2.00645900 & -0.62082100 \\
\hline $\mathrm{H}$ & -3.76674800 & 0.62299200 & -0.54984100 \\
\hline $\mathrm{C}$ & -1.33057500 & 4.16354800 & -0.87265300 \\
\hline $\mathrm{H}$ & -2.01672000 & 5.01930800 & -0.93915100 \\
\hline $\mathrm{H}$ & -0.77948800 & 4.22894700 & 0.07131100 \\
\hline $\mathrm{H}$ & -0.60517500 & 4.23866000 & -1.69146700 \\
\hline $\mathrm{C}$ & -2.82064400 & 2.76837900 & -2.32419600 \\
\hline $\mathrm{H}$ & -3.25488300 & 1.78161700 & -2.50027000 \\
\hline $\mathrm{H}$ & -3.62390700 & 3.51789200 & -2.35006200 \\
\hline $\mathrm{H}$ & -2.12676200 & 2.98551000 & -3.14604600 \\
\hline $\mathrm{C}$ & 1.68350000 & 0.82198500 & 0.16440900 \\
\hline $\mathrm{H}$ & 1.68165600 & 1.44414800 & -0.74361400 \\
\hline $\mathrm{H}$ & 1.55541000 & -0.21530700 & -0.16686800 \\
\hline \multirow[t]{2}{*}{$\mathrm{C}$} & 3.04368800 & 0.96617800 & 0.86583900 \\
\hline & & 74 & \\
\hline
\end{tabular}




\begin{tabular}{|c|c|c|c|}
\hline $\mathrm{H}$ & 3.04512600 & 0.34962400 & 1.77910700 \\
\hline $\mathrm{H}$ & 3.17359000 & 2.00743500 & 1.20354700 \\
\hline $\mathrm{C}$ & 4.24193800 & 0.56770700 & -0.00804500 \\
\hline $\mathrm{H}$ & 4.11295700 & -0.47263000 & -0.34377100 \\
\hline $\mathrm{H}$ & 4.24490400 & 1.18321700 & -0.92152700 \\
\hline $\mathrm{C}$ & 5.59876400 & 0.70604000 & 0.69740000 \\
\hline $\mathrm{H}$ & 5.59504700 & 0.09103600 & 1.61093600 \\
\hline $\mathrm{H}$ & 5.72854600 & 1.74694100 & 1.03330400 \\
\hline $\mathrm{C}$ & 6.79752600 & 0.30518800 & -0.17376300 \\
\hline $\mathrm{H}$ & 6.66850900 & -0.73482100 & -0.51159500 \\
\hline $\mathrm{H}$ & 6.80554300 & 0.92144600 & -1.08649100 \\
\hline $\mathrm{C}$ & 8.15228600 & 0.43925000 & 0.53559000 \\
\hline $\mathrm{H}$ & 8.28239900 & 1.47803100 & 0.87407200 \\
\hline $\mathrm{H}$ & 8.14616300 & -0.17837000 & 1.44603900 \\
\hline $\mathrm{C}$ & 0.48894000 & 1.21395000 & 1.04595000 \\
\hline $\mathrm{H}$ & 0.49152600 & 0.59344800 & 1.95376700 \\
\hline $\mathrm{H}$ & 0.64652300 & 2.25154200 & 1.40654700 \\
\hline $\mathrm{C}$ & 9.34382700 & 0.03765800 & -0.34303200 \\
\hline $\mathrm{H}$ & 9.39915700 & 0.66247000 & -1.24437100 \\
\hline $\mathrm{H}$ & 10.29550800 & 0.14197700 & 0.19404400 \\
\hline $\mathrm{H}$ & 9.25877400 & -1.00669100 & -0.67138200 \\
\hline $\mathrm{O}$ & -2.34309400 & -1.38316300 & 1.26138100 \\
\hline $\mathrm{C}$ & -2.01429700 & -1.69356300 & 2.60739500 \\
\hline $\mathrm{C}$ & -0.57749800 & -2.21525000 & 2.79841900 \\
\hline $\mathrm{H}$ & -0.41471700 & -2.46074400 & 3.85753600 \\
\hline $\mathrm{H}$ & -0.40196900 & -3.11240800 & 2.19774200 \\
\hline $\mathrm{H}$ & 0.16208100 & -1.46913300 & 2.49826000 \\
\hline $\mathrm{C}$ & -3.00719200 & -2.79881200 & 3.02425200 \\
\hline $\mathrm{H}$ & -2.85403700 & -3.69753000 & 2.41465700 \\
\hline $\mathrm{H}$ & -2.88311400 & -3.06830300 & 4.08269500 \\
\hline
\end{tabular}




$\begin{array}{lrrr}\mathrm{H} & -4.03594300 & -2.45362400 & 2.86796800 \\ \mathrm{C} & -2.24539100 & -0.45060100 & 3.48837200 \\ \mathrm{H} & -1.58512800 & 0.36802300 & 3.19487200 \\ \mathrm{H} & -3.27461300 & -0.09463200 & 3.36685600 \\ \mathrm{H} & -2.07659500 & -0.68907400 & 4.54845200\end{array}$

${ }^{i}$ Pr.

C

$-1.30014800$

$-0.19837600$

0.00304400

$\mathrm{H}$

$-1.49097100$

$-0.63986600$

0.99946100

$\mathrm{H}$

$-1.31700800$

$-1.03790100$

$-0.70838500$

$\mathrm{H}$

$-2.14955100$

0.45561200

$-0.22496100$

C

0.00000000

0.53531400

$-0.04531500$

$\mathrm{H}$

$-0.00000100$

1.61293600

0.10314000

C

1.30014800

$-0.19837600$

0.00304400

$\mathrm{H}$

1.31701700

$-1.03788700$

$-0.70840200$

$\mathrm{H}$

2.14955300

0.45561700

$-0.22493900$

$\mathrm{H}$

1.49095900

$-0.63988700$

0.99945400

\section{$\mathbf{B}_{2}$ cat $_{2}$}

C

C

C

C

C

C

$\mathrm{H}$

$\mathrm{H}$

$\mathrm{H}$

$\mathrm{H}$

$\mathrm{O}$
4.11596800

2.94197100

2.94125800

4.11448800

5.31137300

5.31209100

4.10428900

4.10171300

6.25777100

6.25904300

1.63526800
1.43399800

0.69772200

$-0.69737100$

0.00001800

$-1.43487400 \quad-0.00012500$

$-0.70260800 \quad-0.00031100$

$0.70049100 \quad-0.00036100$

$2.51923400 \quad-0.00026600$

$-2.52009800 \quad-0.00006600$

$-1.23599000 \quad-0.00042100$

$1.23288900 \quad-0.00050000$

$-1.14376300 \quad 0.00026400$ 


$\begin{array}{lrrr}\text { O } & 1.63644700 & 1.14549300 & 0.00013900 \\ \text { B } & 0.84350700 & 0.00125700 & 0.00029700 \\ \text { B } & -0.84352200 & 0.00126600 & 0.00055400 \\ \text { C } & -4.11454500 & -1.43484300 & -0.00028000 \\ \text { C } & -5.31142800 & -0.70257600 & -0.00055200 \\ \text { C } & -5.31202700 & 0.70053000 & -0.00048300 \\ \text { C } & -4.11591400 & 1.43399900 & -0.00007600 \\ \text { C } & -2.94181300 & 0.69779700 & 0.00025300 \\ \text { C } & -2.94136100 & -0.69732800 & 0.00008700 \\ \mathrm{H} & -4.10160600 & -2.52006300 & -0.00030100 \\ \mathrm{H} & -6.25789200 & -1.23583600 & -0.00084400 \\ \mathrm{H} & -6.25895000 & 1.23299000 & -0.00076100 \\ \mathrm{H} & -4.10437100 & 2.51924700 & -0.00005100 \\ \mathrm{O} & -1.63641700 & 1.14531800 & 0.00050100 \\ \mathrm{O} & -1.63533500 & -1.14387500 & 0.00054100\end{array}$

\section{TS6}

$\begin{array}{lrrr}\text { C } & 3.88110600 & -0.51514000 & 1.52771300 \\ \mathrm{C} & 2.73598800 & -0.38955800 & 0.75245600 \\ \mathrm{C} & 2.72407300 & -0.72473400 & -0.60869500 \\ \mathrm{C} & 3.85660200 & -1.20176500 & -1.25499500 \\ \mathrm{C} & 5.01740100 & -1.33495800 & -0.47910400 \\ \mathrm{C} & 5.02955800 & -0.99842200 & 0.88374200 \\ \mathrm{H} & 3.87838400 & -0.25486800 & 2.58162000 \\ \mathrm{H} & 3.83587600 & -1.46087100 & -2.30899200 \\ \mathrm{H} & 5.92569700 & -1.70833800 & -0.94394300 \\ \mathrm{H} & 5.94693300 & -1.11645700 & 1.45378300 \\ \mathrm{O} & 1.47621400 & -0.50711300 & -1.11973900 \\ \mathrm{O} & 1.49511100 & 0.04313600 & 1.12500300 \\ \mathrm{~B} & 0.69429200 & 0.02053800 & -0.05243500\end{array}$




\begin{tabular}{|c|c|c|c|}
\hline B & -0.98639100 & -0.16886300 & -0.01520100 \\
\hline $\mathrm{C}$ & -4.26249300 & -0.56110500 & -1.39963100 \\
\hline $\mathrm{C}$ & -5.44538600 & -0.66048700 & -0.64999400 \\
\hline $\mathrm{C}$ & -5.42985200 & -0.60918000 & 0.75130000 \\
\hline $\mathrm{C}$ & -4.23062500 & -0.45629900 & 1.46514300 \\
\hline $\mathrm{C}$ & -3.07164400 & -0.35851700 & 0.71231100 \\
\hline $\mathrm{C}$ & -3.08706500 & -0.40930300 & -0.68199900 \\
\hline $\mathrm{H}$ & -4.26251900 & -0.60158000 & -2.48430600 \\
\hline $\mathrm{H}$ & -6.39220300 & -0.78105700 & -1.16896800 \\
\hline $\mathrm{H}$ & -6.36481500 & -0.69072800 & 1.29858200 \\
\hline $\mathrm{H}$ & -4.20627500 & -0.41759900 & 2.54960400 \\
\hline $\mathrm{O}$ & -1.76847500 & -0.20476500 & 1.14046300 \\
\hline $\mathrm{O}$ & -1.79424300 & -0.28762500 & -1.14862000 \\
\hline $\mathrm{C}$ & 0.56686000 & 2.17161300 & -0.55597900 \\
\hline $\mathrm{H}$ & -0.11051100 & 2.04942700 & -1.40322900 \\
\hline $\mathrm{C}$ & 1.97319600 & 2.54450200 & -0.93584100 \\
\hline $\mathrm{H}$ & 2.67126800 & 2.42645800 & -0.09847400 \\
\hline $\mathrm{H}$ & 2.34332200 & 1.96610100 & -1.78687600 \\
\hline $\mathrm{H}$ & 2.00247500 & 3.60991600 & -1.22436900 \\
\hline $\mathrm{C}$ & -0.01975700 & 2.86548500 & 0.64473300 \\
\hline $\mathrm{H}$ & -1.02942300 & 2.51911200 & 0.88605300 \\
\hline $\mathrm{H}$ & 0.60864700 & 2.73010500 & 1.53248800 \\
\hline $\mathrm{H}$ & -0.08298600 & 3.95016100 & 0.45139800 \\
\hline
\end{tabular}

\section{INT5}

$\begin{array}{llll}\text { C } & -3.37588400 & -1.32102800 & -1.33711600 \\ C & -2.45123500 & -0.54031800 & -0.62775600 \\ C & -2.39133800 & -0.57653000 & 0.79907900 \\ C & -3.25228700 & -1.39662400 & 1.54314500 \\ C & -4.16368200 & -2.16524600 & 0.82925400\end{array}$




\begin{tabular}{|c|c|c|c|}
\hline $\mathrm{C}$ & -4.22454400 & -2.12782100 & -0.58914500 \\
\hline $\mathrm{H}$ & -3.41224400 & -1.28763600 & -2.42109900 \\
\hline $\mathrm{H}$ & -3.19732300 & -1.41877500 & 2.62667500 \\
\hline $\mathrm{H}$ & -4.84959400 & -2.81451700 & 1.36608300 \\
\hline $\mathrm{H}$ & -4.95502900 & -2.74995300 & -1.09861100 \\
\hline $\mathrm{O}$ & -1.45091500 & 0.23729600 & 1.24347800 \\
\hline $\mathrm{O}$ & -1.54909000 & 0.29434800 & -1.10785600 \\
\hline B & -0.78282700 & 0.88868300 & 0.04730500 \\
\hline B & 0.87226200 & 0.35277800 & 0.01231000 \\
\hline $\mathrm{C}$ & 4.34393000 & 0.39549200 & 0.88032500 \\
\hline $\mathrm{C}$ & 5.29172400 & -0.54969100 & 0.45588000 \\
\hline $\mathrm{C}$ & 4.93384700 & -1.62206600 & -0.37343200 \\
\hline $\mathrm{C}$ & 3.61230300 & -1.79645800 & -0.81489500 \\
\hline $\mathrm{C}$ & 2.68821100 & -0.85728900 & -0.38701000 \\
\hline $\mathrm{C}$ & 3.04452400 & 0.21010700 & 0.43750200 \\
\hline $\mathrm{H}$ & 4.60998300 & 1.22967400 & 1.52187800 \\
\hline $\mathrm{H}$ & 6.32405300 & -0.44564500 & 0.77822200 \\
\hline $\mathrm{H}$ & 5.69364400 & -2.33456900 & -0.68248200 \\
\hline $\mathrm{H}$ & 3.32402500 & -2.62240600 & -1.45753800 \\
\hline $\mathrm{O}$ & 1.33701700 & -0.77941500 & -0.66057300 \\
\hline $\mathrm{O}$ & 1.92210300 & 0.97311100 & 0.69169800 \\
\hline $\mathrm{C}$ & -0.91875100 & 2.53215800 & 0.09570100 \\
\hline $\mathrm{H}$ & -0.35699100 & 2.84276500 & 0.98900100 \\
\hline $\mathrm{C}$ & -2.37967000 & 2.98436300 & 0.25891700 \\
\hline $\mathrm{H}$ & -2.99066400 & 2.69075000 & -0.60481600 \\
\hline $\mathrm{H}$ & -2.84291900 & 2.56571400 & 1.16002700 \\
\hline $\mathrm{H}$ & -2.43794500 & 4.07949200 & 0.33825900 \\
\hline $\mathrm{C}$ & -0.27356600 & 3.18986000 & -1.13485300 \\
\hline $\mathrm{H}$ & 0.79244900 & 2.94731700 & -1.22010500 \\
\hline \multirow[t]{2}{*}{$\mathrm{H}$} & -0.76585000 & 2.86989100 & -2.06211400 \\
\hline & & 79 & \\
\hline
\end{tabular}


$-1.07900100$

TS7

C

2.98365000

$-1.85032500$

1.29862600

C

2.45954600

$-0.78595900$

0.58262000

C

2.12285000

$-0.89799700$

$-0.76876600$

C

2.29122100

$-2.07990100$

$-1.47234600$

C

2.82535600

$-3.16487700$

$-0.75950800$

C

3.16402700

$-3.05249500$

0.59654100

$\mathrm{H}$

3.24022700

$-1.75268400$

2.34879800

$\mathrm{H}$

2.02361300

$-2.15593400$

$-2.52160300$

$\mathrm{H}$

2.97831600

$-4.11098600$

$-1.27129500$

$\mathrm{H}$

3.57471300

$-3.91313900$

1.11718700

$\mathrm{O}$

1.62852600

0.30765800

$-1.21238600$

$\mathrm{O}$

2.18577500

0.49204000

1.01266000

B

1.64954900

1.16860200

$-0.09569200$

B

$-0.88009700$

0.60442100

0.29637300

C

$-4.33418700$

0.85539500

$-0.48638300$

C

$-5.26003100$

$-0.19251300$

$-0.35818200$

C

$-4.87401000$

$-1.45822600$

0.10519500

C

$-3.54450700$

$-1.73482500$

0.46226100

C

$-2.64423000$

$-0.69199100$

0.32997100

C

$-3.02814800$

0.56672000

$-0.13084900$

$\mathrm{H}$

$-4.62122200$

1.83890500

$-0.84416700$

$\mathrm{H}$

$-6.29806200$

$-0.01601700$

$-0.62529900$

$\mathrm{H}$

$-5.61852100$

$-2.24462000$

0.19081100

$-3.23382100$

$-2.71047700$

0.82166300

$-1.27961400$

$-0.67537600$

0.60627800

$\mathrm{O}$

$-1.91110800$

1.39872800

$-0.15485700$

C

1.48692600

2.73443000

$-0.19212500$ 


$\begin{array}{llll}\mathrm{H} & 0.64494000 & 2.95395200 & -0.86404900 \\ \mathrm{C} & 2.76107700 & 3.32440800 & -0.85206000 \\ \mathrm{H} & 3.64971100 & 3.14443300 & -0.23323200 \\ \mathrm{H} & 2.94516100 & 2.89074000 & -1.84171300 \\ \mathrm{H} & 2.65922500 & 4.41095600 & -0.97412600 \\ \mathrm{C} & 1.21819700 & 3.40607800 & 1.16663300 \\ \mathrm{H} & 0.28805600 & 3.04672900 & 1.62284400 \\ \mathrm{H} & 2.03159100 & 3.20642100 & 1.87488900 \\ \mathrm{H} & 1.13376400 & 4.49468000 & 1.05256200\end{array}$

\section{-Bcat (INT6)}

C

C

C

C

C

C

$\mathrm{H}$

$\mathrm{H}$

$\mathrm{H}$

$\mathrm{H}$

$\mathrm{O}$

$\mathrm{O}$

B

${ }^{i}$ PrBcat

C

C

C

C

$\begin{array}{rrr}0.84409200 & -1.43452400 & -0.00012800 \\ -0.32725900 & -0.69699500 & -0.00009400 \\ -0.32730000 & 0.69712700 & -0.00025500 \\ 0.84425600 & 1.43448800 & -0.00037700 \\ 2.04146300 & 0.70102900 & 0.00015300 \\ 2.04140200 & -0.70116900 & 0.00021900 \\ 0.83139800 & -2.51964300 & -0.00009200 \\ 0.83191200 & 2.51962600 & -0.00033800 \\ 2.98788800 & 1.23419800 & 0.00045100 \\ 2.98781500 & -1.23433800 & 0.00050400 \\ -1.64451100 & 1.14888700 & 0.00024700 \\ -1.64456500 & -1.14885500 & -0.00016500 \\ -2.40526700 & 0.00003200 & 0.00034200\end{array}$

$-2.40526700$ 0.00034200 


\begin{tabular}{|c|c|c|c|}
\hline $\mathrm{C}$ & -3.34822100 & 0.70087300 & 0.10475100 \\
\hline $\mathrm{C}$ & -3.34827800 & -0.70075000 & 0.10451300 \\
\hline $\mathrm{H}$ & -2.14052500 & -2.51839300 & 0.02632200 \\
\hline $\mathrm{H}$ & -2.14032800 & 2.51844600 & 0.02717700 \\
\hline $\mathrm{H}$ & -4.29233300 & 1.23481500 & 0.16663200 \\
\hline $\mathrm{H}$ & -4.29243400 & -1.23463400 & 0.16621300 \\
\hline $\mathrm{O}$ & 0.32210800 & 1.14591000 & -0.13336200 \\
\hline $\mathrm{O}$ & 0.32201500 & -1.14600700 & -0.13374400 \\
\hline B & 1.11729300 & -0.00006700 & -0.18939300 \\
\hline $\mathrm{C}$ & 2.68068200 & -0.00015400 & -0.33716400 \\
\hline $\mathrm{H}$ & 2.87057600 & -0.00062800 & -1.42584500 \\
\hline $\mathrm{C}$ & 3.32950800 & -1.27654200 & 0.23731900 \\
\hline $\mathrm{H}$ & 2.89458500 & -2.18426700 & -0.19507000 \\
\hline $\mathrm{H}$ & 4.40848700 & -1.28785200 & 0.03658700 \\
\hline $\mathrm{H}$ & 3.19622100 & -1.33266200 & 1.32543000 \\
\hline $\mathrm{C}$ & 3.32959900 & 1.27666600 & 0.23622200 \\
\hline $\mathrm{H}$ & 4.40858700 & 1.28768400 & 0.03552100 \\
\hline $\mathrm{H}$ & 2.89477900 & 2.18404800 & -0.19699200 \\
\hline $\mathrm{H}$ & 3.19627000 & 1.33375900 & 1.32427500 \\
\hline
\end{tabular}

TS8

C

C

C

C

C

C

$\mathrm{H}$

$\mathrm{H}$

$\mathrm{H}$

$\begin{array}{lll}3.51947900 & -1.37938100 & 0.39293800 \\ 2.47788300 & -0.73680500 & -0.25818500 \\ 2.42873300 & 0.65488000 & -0.37365500 \\ 3.41861300 & 1.46727400 & 0.15721400 \\ 4.48147500 & 0.82842800 & 0.81970400 \\ 4.53094400 & -0.56731000 & 0.93527200 \\ 3.54360400 & -2.46162500 & 0.48170600 \\ 3.36587200 & 2.54840300 & 0.06737700 \\ 5.27626600 & 1.43059000 & 1.25392200 \\ & 82 & \end{array}$




\begin{tabular}{|c|c|c|c|}
\hline $\mathrm{H}$ & 5.36373800 & -1.03261200 & 1.45756800 \\
\hline $\mathrm{O}$ & 1.29188400 & 1.00681100 & -1.06478200 \\
\hline $\mathrm{O}$ & 1.37256400 & -1.27649100 & -0.87534100 \\
\hline B & 0.61801700 & -0.19374300 & -1.37499000 \\
\hline $\mathrm{O}$ & -3.20704400 & -0.04856200 & 1.42304700 \\
\hline $\mathrm{C}$ & -3.99852600 & 0.03110300 & 0.31922700 \\
\hline $\mathrm{C}$ & -4.16705500 & 1.50008400 & -0.16656300 \\
\hline $\mathrm{H}$ & -4.60685300 & 2.10380100 & 0.63875400 \\
\hline $\mathrm{H}$ & -3.18020700 & 1.91783200 & -0.40092900 \\
\hline $\mathrm{H}$ & -4.80590800 & 1.58931400 & -1.06009300 \\
\hline $\mathrm{C}$ & -3.39898100 & -0.81458400 & -0.85013200 \\
\hline $\mathrm{H}$ & -3.26140100 & -1.85071200 & -0.51692600 \\
\hline $\mathrm{H}$ & -4.05068700 & -0.81003600 & -1.73906200 \\
\hline $\mathrm{H}$ & -2.41476300 & -0.41638800 & -1.12353200 \\
\hline $\mathrm{C}$ & -5.41200800 & -0.55243700 & 0.64607800 \\
\hline $\mathrm{H}$ & -5.86120600 & 0.01901700 & 1.46850300 \\
\hline $\mathrm{H}$ & -6.09191100 & -0.51584900 & -0.21977500 \\
\hline $\mathrm{H}$ & -5.30920800 & -1.59459600 & 0.97267000 \\
\hline
\end{tabular}

\section{INT7}

$\begin{array}{llll}\mathrm{C} & -3.05368900 & -1.31628600 & 0.00933700 \\ \mathrm{C} & -1.76302000 & -0.80516100 & -0.02351300 \\ \mathrm{C} & -1.51499700 & 0.56816000 & -0.02889800 \\ \mathrm{C} & -2.53874700 & 1.50486800 & 0.01052700 \\ \mathrm{C} & -3.85351000 & 0.99795300 & 0.00614800 \\ \mathrm{C} & -4.10504300 & -0.37726800 & 0.00442300 \\ \mathrm{H} & -3.23598700 & -2.38629900 & 0.01585800 \\ \mathrm{H} & -2.32903400 & 2.56943200 & 0.01634800 \\ \mathrm{H} & -4.68839800 & 1.69562800 & 0.01815900 \\ \mathrm{H} & -5.13322000 & -0.73367200 & 0.01291600\end{array}$




$\begin{array}{lrrr}\mathrm{O} & -0.15100200 & 0.78406500 & -0.00773300 \\ \mathrm{O} & -0.56937100 & -1.48901700 & -0.00336600 \\ \mathrm{~B} & 0.42373200 & -0.49478600 & 0.00510000 \\ \mathrm{O} & 1.72455500 & -0.82455600 & -0.01890500 \\ \mathrm{C} & 2.87171100 & 0.07661600 & 0.00332500 \\ \mathrm{C} & 2.83486200 & 0.98775300 & -1.23037400 \\ \mathrm{H} & 2.76465400 & 0.38695900 & -2.14641900 \\ \mathrm{H} & 1.98214100 & 1.67423500 & -1.19865300 \\ \mathrm{H} & 3.75431500 & 1.58726600 & -1.28185100 \\ \mathrm{C} & 2.86476400 & 0.87843800 & 1.31017900 \\ \mathrm{H} & 2.83649600 & 0.20223700 & 2.17407500 \\ \mathrm{H} & 3.77429900 & 1.49141100 & 1.38148200 \\ \mathrm{H} & 1.99854600 & 1.54669100 & 1.36687100 \\ \mathrm{C} & 4.08499700 & -0.85711700 & -0.05223700 \\ \mathrm{H} & 4.06413000 & -1.45695400 & -0.97056200 \\ \mathrm{H} & 5.01512800 & -0.27525900 & -0.03375100 \\ \mathrm{H} & 4.08084500 & -1.53941800 & 0.80655700\end{array}$

${ }^{i}$ PrI

C

$\mathrm{H}$

$\mathrm{H}$

H

C

$\mathrm{H}$

C

$\mathrm{H}$

$\mathrm{H}$

$\mathrm{H}$

$\begin{array}{rrr}0.05102700 & -1.96608500 & -1.27565700 \\ -0.24879600 & -3.02450600 & -1.28707100 \\ 1.14440700 & -1.92430400 & -1.32588500 \\ -0.35495900 & -1.48867200 & -2.17194700 \\ -0.47247500 & -1.32464000 & 0.00000000 \\ -1.56323300 & -1.28353900 & 0.00000000 \\ 0.05102700 & -1.96608500 & 1.27565700 \\ 1.14440700 & -1.92430400 & 1.32588500 \\ -0.35495900 & -1.48867200 & 2.17194700 \\ -0.24879600 & -3.02450600 & 1.28707100 \\ 0.05102700 & 0.86225200 & 0.00000000\end{array}$




\section{${ }^{t} \mathrm{BuOBcat}$}

C

C

C

C

C

C

$\mathrm{H}$

$\mathrm{H}$

$\mathrm{H}$

$\mathrm{H}$

$\mathrm{O}$

$\mathrm{O}$

B

O

C

C

$\mathrm{H}$

$\mathrm{H}$

$\mathrm{H}$

C

$\mathrm{H}$

$\mathrm{H}$

$\mathrm{H}$

C

$\mathrm{H}$

$\mathrm{H}$

$\mathrm{H}$

\begin{tabular}{|c|c|c|}
\hline-3.05526900 & -1.30980600 & 0.00000400 \\
\hline-1.76493200 & -0.80847900 & -0.00002600 \\
\hline-1.50850000 & 0.56519000 & -0.00002600 \\
\hline-2.52461700 & 1.50400200 & 0.00000500 \\
\hline-3.84004100 & 1.00795200 & 0.00003500 \\
\hline-4.09881700 & -0.36810800 & 0.00003400 \\
\hline-3.24476700 & -2.37856100 & 0.00000400 \\
\hline-2.31187100 & 2.56849300 & 0.00000600 \\
\hline-4.66996700 & 1.70901200 & 0.00006200 \\
\hline-5.12716900 & -0.71864000 & 0.00006000 \\
\hline-0.14097200 & 0.77147600 & -0.00005600 \\
\hline-0.57212000 & -1.49856600 & -0.00005500 \\
\hline 0.42382000 & -0.51404200 & -0.00005100 \\
\hline 1.72616000 & -0.83518100 & -0.00001700 \\
\hline 2.86650600 & 0.07668000 & 0.00000600 \\
\hline 2.83105900 & 0.93741100 & -1.26903900 \\
\hline 2.81050700 & 0.30195500 & -2.16160100 \\
\hline 1.95349500 & 1.59098400 & -1.28311900 \\
\hline 3.72657400 & 1.56757200 & -1.31932300 \\
\hline 2.83107400 & 0.93716200 & 1.26922300 \\
\hline 2.81035400 & 0.30151600 & 2.16164600 \\
\hline 3.72666600 & 1.56719500 & 1.31970100 \\
\hline 1.95358400 & 1.59082900 & 1.28335500 \\
\hline 4.09040200 & -0.84337400 & -0.00008200 \\
\hline 4.08728300 & -1.48556600 & -0.88735200 \\
\hline 5.01318900 & -0.25247400 & -0.00003900 \\
\hline 4.08729700 & -1.48571800 & 0.88707700 \\
\hline
\end{tabular}




\begin{tabular}{|c|c|c|c|}
\hline $\mathrm{C}$ & -3.09338800 & -0.00034500 & -0.71773600 \\
\hline $\mathrm{C}$ & -2.93251500 & -0.67735200 & 0.69861400 \\
\hline $\mathrm{C}$ & 2.77417500 & -0.58042800 & 0.75954600 \\
\hline $\mathrm{C}$ & 2.52320800 & -1.01204900 & -0.74801800 \\
\hline B & -0.90842100 & 0.15146700 & -0.01763600 \\
\hline B & 0.81609200 & 0.40725000 & -0.05815600 \\
\hline $\mathrm{O}$ & 1.49528200 & -0.09338800 & -1.19087200 \\
\hline $\mathrm{O}$ & -1.48018000 & -0.76127000 & 0.83888800 \\
\hline $\mathrm{O}$ & -1.83553300 & 0.72904400 & -0.85582300 \\
\hline $\mathrm{O}$ & 1.55820200 & 0.12707900 & 1.10215600 \\
\hline $\mathrm{C}$ & -3.43626000 & 0.19145100 & 1.85930200 \\
\hline $\mathrm{H}$ & -4.52984300 & 0.26213500 & 1.86463900 \\
\hline $\mathrm{H}$ & -3.11502300 & -0.25879500 & 2.80410000 \\
\hline $\mathrm{H}$ & -3.02347400 & 1.20427200 & 1.81317500 \\
\hline $\mathrm{C}$ & -3.50918000 & -2.08731800 & 0.81722700 \\
\hline $\mathrm{H}$ & -4.59591100 & -2.07911900 & 0.66834500 \\
\hline $\mathrm{H}$ & -3.06277200 & -2.77185900 & 0.09192000 \\
\hline $\mathrm{H}$ & -3.30771300 & -2.48008000 & 1.81946900 \\
\hline $\mathrm{C}$ & -3.14785900 & -1.00470000 & -1.87739100 \\
\hline $\mathrm{H}$ & -2.31850700 & -1.71757600 & -1.83117000 \\
\hline $\mathrm{H}$ & -4.08975400 & -1.56482200 & -1.88133100 \\
\hline $\mathrm{H}$ & -3.06772100 & -0.45851100 & -2.82294300 \\
\hline $\mathrm{C}$ & -4.24487800 & 0.99668500 & -0.83586900 \\
\hline $\mathrm{H}$ & -4.15264700 & 1.81101200 & -0.11313800 \\
\hline $\mathrm{H}$ & -4.24862500 & 1.43470100 & -1.83965900 \\
\hline $\mathrm{H}$ & -5.20934700 & 0.49833300 & -0.67984900 \\
\hline $\mathrm{C}$ & 3.73501200 & -0.87032900 & -1.67220600 \\
\hline $\mathrm{H}$ & 4.55099500 & -1.53054800 & -1.35380500 \\
\hline $\mathrm{H}$ & 3.44938000 & -1.15170500 & -2.69154500 \\
\hline
\end{tabular}




\begin{tabular}{|c|c|c|c|}
\hline $\mathrm{H}$ & 4.10953500 & 0.15587400 & -1.69979700 \\
\hline $\mathrm{C}$ & 1.93595900 & -2.42712100 & -0.89038000 \\
\hline $\mathrm{H}$ & 1.65048500 & -2.58576000 & -1.93583700 \\
\hline $\mathrm{H}$ & 2.66225000 & -3.19900000 & -0.61138700 \\
\hline $\mathrm{H}$ & 1.04051900 & -2.55151500 & -0.27358600 \\
\hline $\mathrm{C}$ & 3.95758600 & 0.37994600 & 0.94821700 \\
\hline $\mathrm{H}$ & 4.91436200 & -0.13371100 & 0.79842000 \\
\hline $\mathrm{H}$ & 3.91322600 & 1.22735700 & 0.26162300 \\
\hline $\mathrm{H}$ & 3.93599600 & 0.76990400 & 1.97160700 \\
\hline $\mathrm{C}$ & 2.92567200 & -1.74591600 & 1.74436700 \\
\hline $\mathrm{H}$ & 2.03894800 & -2.38377300 & 1.75708300 \\
\hline $\mathrm{H}$ & 3.80001300 & -2.36070300 & 1.49729100 \\
\hline $\mathrm{H}$ & 3.06558600 & -1.34873800 & 2.75562200 \\
\hline $\mathrm{C}$ & 0.62284500 & 2.41968500 & -0.27178000 \\
\hline $\mathrm{H}$ & -0.16221900 & 2.42165400 & -1.02859400 \\
\hline $\mathrm{C}$ & 0.18076000 & 2.97919100 & 1.06159400 \\
\hline $\mathrm{H}$ & 0.07968200 & 4.07500800 & 0.98997400 \\
\hline $\mathrm{H}$ & -0.78878500 & 2.58302500 & 1.38108800 \\
\hline $\mathrm{H}$ & 0.91207000 & 2.76494300 & 1.84898000 \\
\hline $\mathrm{C}$ & 1.93069400 & 2.96597100 & -0.79718200 \\
\hline $\mathrm{H}$ & 2.71713700 & 2.95498300 & -0.03559800 \\
\hline $\mathrm{H}$ & 2.27907600 & 2.42396300 & -1.68099700 \\
\hline $\mathrm{H}$ & 1.78157400 & 4.01953100 & -1.08975100 \\
\hline
\end{tabular}

\section{INT8}
C
$-2.99923800$
$0.03174200 \quad-0.69816000$
C
$\begin{array}{lll}-2.78711100 & -0.65017500 & 0.71142500\end{array}$
C
$\begin{array}{lll}2.64330100 & -0.66937100 & 0.73740400\end{array}$
C
2.25496700
$-1.10613600$
$-0.73895200$
B
$-0.83708700$
0.29224800
$-0.01535000$ 


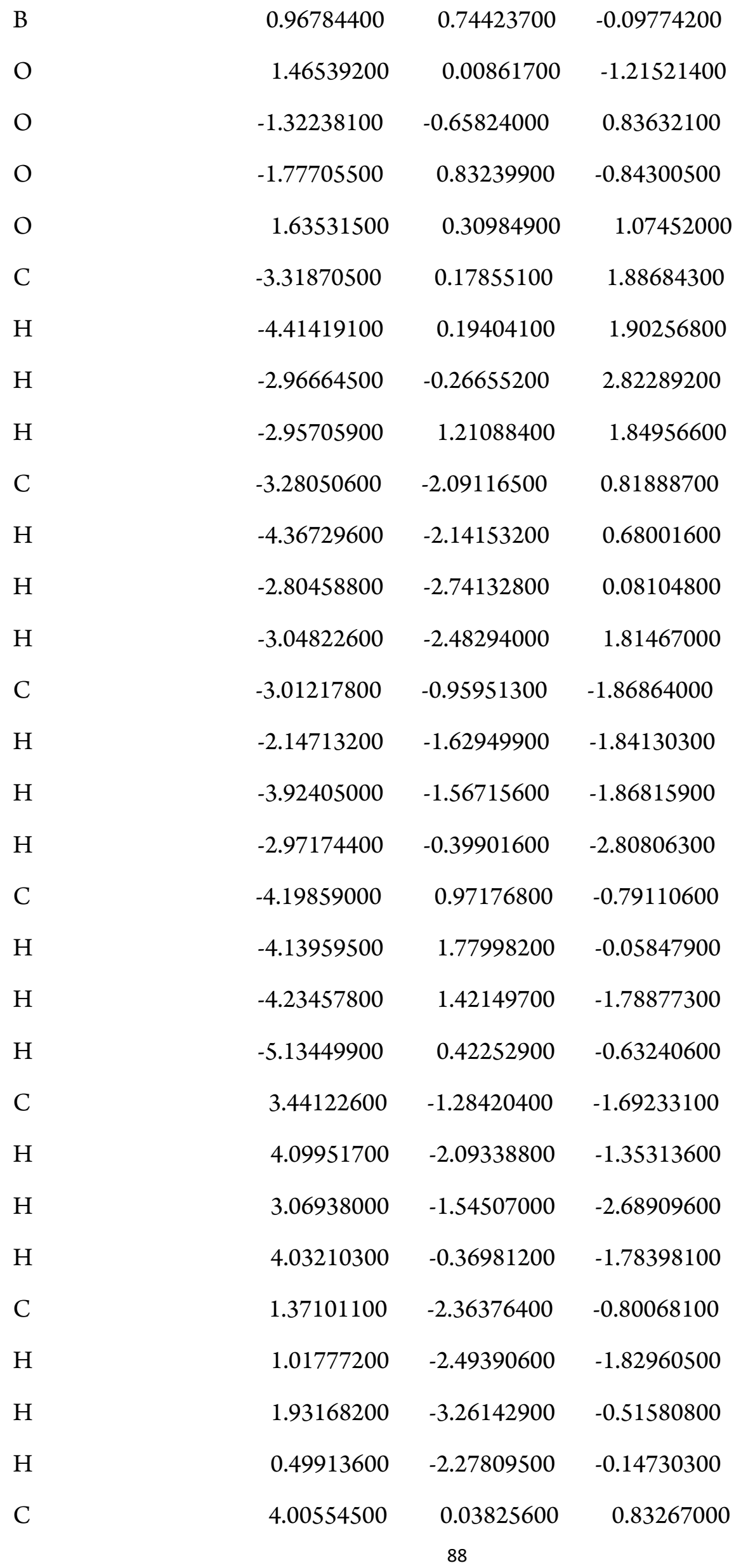




$\begin{array}{lrrr}\mathrm{H} & 4.83264800 & -0.65814900 & 0.65211800 \\ \mathrm{H} & 4.08656900 & 0.86424900 & 0.12099400 \\ \mathrm{H} & 4.11843500 & 0.45021100 & 1.84113700 \\ \mathrm{C} & 2.58791400 & -1.79380700 & 1.77605500 \\ \mathrm{H} & 1.58885000 & -2.23040900 & 1.84467900 \\ \mathrm{H} & 3.30559200 & -2.58812600 & 1.53636500 \\ \mathrm{H} & 2.84580800 & -1.39006100 & 2.76110200 \\ \mathrm{C} & 0.77868900 & 2.40540000 & -0.29779000 \\ \mathrm{H} & 0.08430100 & 2.55719200 & -1.13171200 \\ \mathrm{C} & 0.23008900 & 3.09953200 & 0.95436200 \\ \mathrm{H} & 0.20319800 & 4.18917700 & 0.81048600 \\ \mathrm{H} & -0.79109000 & 2.77954200 & 1.19487900 \\ \mathrm{H} & 0.85875200 & 2.89299900 & 1.82870800 \\ \mathrm{C} & 2.14830600 & 2.99096800 & -0.69263200 \\ \mathrm{H} & 2.87555200 & 2.89263500 & 0.12190600 \\ \mathrm{H} & 2.55746000 & 2.50514200 & -1.58441900 \\ \mathrm{H} & 2.04165800 & 4.06446500 & -0.91054300\end{array}$

\section{TS10}

$\begin{array}{lrrr}\text { C } & -3.15379200 & 0.22258200 & -0.61286300 \\ \text { C } & -2.91550800 & -0.76555600 & 0.59721200 \\ \text { C } & 2.66341600 & -0.82378500 & 0.73144900 \\ \text { C } & 2.31399000 & -1.09908100 & -0.79694300 \\ \text { B } & -0.97165700 & 0.27448200 & 0.02834500 \\ \text { B } & 1.30921500 & 0.87552100 & -0.08592400 \\ \text { O } & 1.67354200 & 0.13493400 & -1.21332900 \\ \text { O } & -1.43941000 & -0.83644900 & 0.65663400 \\ \text { O } & -1.90596100 & 1.01298300 & -0.62205500 \\ \text { O } & 1.80079200 & 0.28863500 & 1.07900200 \\ \text { C } & -3.37360400 & -0.21152800 & 1.95071200\end{array}$




\begin{tabular}{|c|c|c|c|}
\hline $\mathrm{H}$ & -4.46680500 & -0.18058800 & 2.01947700 \\
\hline $\mathrm{H}$ & -2.99704100 & -0.86210400 & 2.74638900 \\
\hline $\mathrm{H}$ & -2.98471500 & 0.79597200 & 2.12838100 \\
\hline $\mathrm{C}$ & -3.45070000 & -2.18006100 & 0.39494400 \\
\hline $\mathrm{H}$ & -4.54195500 & -2.16726200 & 0.28571300 \\
\hline $\mathrm{H}$ & -3.01839800 & -2.65871400 & -0.48680000 \\
\hline $\mathrm{H}$ & -3.20542900 & -2.79356200 & 1.26811000 \\
\hline $\mathrm{C}$ & -3.23266800 & -0.47345000 & -1.97622500 \\
\hline $\mathrm{H}$ & -2.38703500 & -1.14962300 & -2.13593600 \\
\hline $\mathrm{H}$ & -4.16162200 & -1.04536300 & -2.07934600 \\
\hline $\mathrm{H}$ & -3.20750800 & 0.28631600 & -2.76380500 \\
\hline $\mathrm{C}$ & -4.32363400 & 1.18732200 & -0.44278600 \\
\hline $\mathrm{H}$ & -4.21695700 & 1.80469900 & 0.45200100 \\
\hline $\mathrm{H}$ & -4.37579300 & 1.85416600 & -1.30952500 \\
\hline $\mathrm{H}$ & -5.27145400 & 0.63889900 & -0.37933500 \\
\hline $\mathrm{C}$ & 3.52897500 & -1.32008600 & -1.70396500 \\
\hline $\mathrm{H}$ & 4.08276300 & -2.21953200 & -1.40835700 \\
\hline $\mathrm{H}$ & 3.18872600 & -1.45611900 & -2.73625400 \\
\hline $\mathrm{H}$ & 4.21311700 & -0.46833300 & -1.68761500 \\
\hline $\mathrm{C}$ & 1.31692000 & -2.24659100 & -1.01614000 \\
\hline $\mathrm{H}$ & 1.01403900 & -2.25094300 & -2.06921000 \\
\hline $\mathrm{H}$ & 1.77237900 & -3.21749800 & -0.78940000 \\
\hline $\mathrm{H}$ & 0.41982000 & -2.13473600 & -0.40363800 \\
\hline $\mathrm{C}$ & 4.10416800 & -0.33903800 & 0.95788900 \\
\hline $\mathrm{H}$ & 4.83493500 & -1.12887800 & 0.75001700 \\
\hline $\mathrm{H}$ & 4.34051200 & 0.52749600 & 0.33275100 \\
\hline $\mathrm{H}$ & 4.21380400 & -0.03620700 & 2.00453500 \\
\hline $\mathrm{C}$ & 2.36035700 & -1.98429900 & 1.68212400 \\
\hline $\mathrm{H}$ & 1.30502600 & -2.26488500 & 1.65290700 \\
\hline $\mathrm{H}$ & 2.96765800 & -2.86414400 & 1.43694100 \\
\hline & & 90 & \\
\hline
\end{tabular}




$\begin{array}{lrrr}\mathrm{H} & 2.59928300 & -1.68313800 & 2.70791500 \\ \mathrm{C} & 1.00179300 & 2.44723500 & -0.18483900 \\ \mathrm{H} & 0.24388500 & 2.62119200 & -0.95990100 \\ \mathrm{C} & 0.50767100 & 3.06574800 & 1.13382700 \\ \mathrm{H} & 0.36506500 & 4.15028800 & 1.02990000 \\ \mathrm{H} & -0.45029300 & 2.63876200 & 1.45559700 \\ \mathrm{H} & 1.22946200 & 2.89767100 & 1.94258800 \\ \mathrm{C} & 2.30024800 & 3.15303800 & -0.65112800 \\ \mathrm{H} & 3.10766100 & 3.02785700 & 0.08281400 \\ \mathrm{H} & 2.65134900 & 2.76009600 & -1.61189500 \\ \mathrm{H} & 2.13022700 & 4.23267900 & -0.76874100\end{array}$

\section{${ }^{i}$ PrBpin}

C

C

B

O

$\mathrm{O}$

C

$\mathrm{H}$

$\mathrm{H}$

$\mathrm{H}$

C

$\mathrm{H}$

$\mathrm{H}$

$\mathrm{H}$

C

$\mathrm{H}$

$\mathrm{H}$

$\mathrm{H}$

\begin{tabular}{rrr}
-1.26756600 & -0.77024900 & -0.06940600 \\
-1.20234000 & 0.79841900 & 0.10795700 \\
0.91082600 & -0.05277200 & -0.18953500 \\
0.16456800 & 1.09951600 & -0.30002200 \\
0.13044900 & -1.15629100 & 0.07899600 \\
-2.15944800 & 1.59376700 & -0.77863100 \\
-3.20277600 & 1.35290200 & -0.54134700 \\
-2.01189300 & 2.66532300 & -0.60694300 \\
-1.98867300 & 1.39728800 & -1.83995000 \\
-1.33769400 & 1.25559800 & 1.56701300 \\
-1.09474000 & 2.32147000 & 1.62907200 \\
-2.35763800 & 1.11234300 & 1.94048400 \\
-0.64826100 & 0.71395200 & 2.22292000 \\
-1.69958800 & -1.21095800 & -1.47507800 \\
-2.76200200 & -1.00999600 & -1.65183900 \\
-1.11694800 & -0.70581000 & -2.25247900 \\
-1.53232100 & -2.28839500 & -1.57533900 \\
\hline & 91 & \\
\hline
\end{tabular}




$\begin{array}{lrrr}\mathrm{C} & -2.08995100 & -1.51066200 & 0.98417400 \\ \mathrm{H} & -1.70955800 & -1.33504700 & 1.99339500 \\ \mathrm{H} & -3.14129400 & -1.20069200 & 0.94722900 \\ \mathrm{H} & -2.04760400 & -2.58791100 & 0.79116700 \\ \mathrm{C} & 2.47668600 & -0.11724000 & -0.38791700 \\ \mathrm{H} & 2.62222900 & -0.40627900 & -1.44471800 \\ \mathrm{C} & 3.13249400 & -1.21800100 & 0.47179000 \\ \mathrm{H} & 2.66143100 & -2.19345500 & 0.30860100 \\ \mathrm{H} & 4.20196400 & -1.31200700 & 0.24050100 \\ \mathrm{H} & 3.04842900 & -0.98626600 & 1.54203800 \\ \mathrm{C} & 3.16775000 & 1.24499000 & -0.18648900 \\ \mathrm{H} & 4.23861600 & 1.18205000 & -0.42218500 \\ \mathrm{H} & 2.72508600 & 2.02175700 & -0.81976500 \\ \mathrm{H} & 3.07963800 & 1.58284200 & 0.85456600 \\ & & & \\ & & & \\ & & & \end{array}$

\section{$\mathrm{MeOH}$}

C

$\mathrm{H}$

$\mathrm{H}$

$\mathrm{H}$

$\mathrm{O}$

$\mathrm{H}$

\section{- $\mathrm{CH}_{2} \mathrm{OH}$}

C

$\mathrm{H}$

$\mathrm{H}$

O

$\mathrm{H}$

$\begin{array}{rrr}0.66901500 & -0.02081700 & 0.00000000 \\ 1.08099300 & 0.99121400 & -0.00010700 \\ 1.02890400 & -0.54660700 & 0.89614200 \\ 1.02888900 & -0.54678900 & -0.89604000 \\ -0.74964800 & 0.12298200 & 0.00000000 \\ -1.15569400 & -0.75677800 & 0.00000200\end{array}$
0.75677800 
$\cdot . \mathrm{CCH}_{3}$

$\begin{array}{lrrr}\mathrm{C} & -0.57732900 & -0.00008000 & 0.01316000 \\ \mathrm{H} & -0.87098500 & 0.00294200 & -1.05842100 \\ \mathrm{H} & -1.00667100 & -0.91305400 & 0.45701600 \\ \mathrm{H} & -1.00642800 & 0.91082400 & 0.46156200 \\ \mathrm{O} & 0.79350800 & -0.00002900 & 0.00761000\end{array}$

${ }^{n} \mathrm{C}_{8} \mathrm{H}_{18}$

C

$\mathrm{H}$

$\mathrm{H}$

$\mathrm{H}$

C

$\mathrm{H}$

$\mathrm{H}$

C

$\mathrm{H}$

H

C

H

$\mathrm{H}$

C

$\mathrm{H}$

$\mathrm{H}$

C

$\mathrm{H}$

$\mathrm{H}$

C

$\mathrm{H}$

$\mathrm{H}$
$-4.50381100$

$-4.57452400$

$-4.57449100$

$-5.37826800$

$-3.19454500$

$-3.16972500$

$-3.16974200$

$-1.94211800$

$-1.96841300$

$-1.96840400$

$-0.62592500$

$-0.60073300$

$-0.60070600$

0.62592500

0.60071500

0.60072400

1.94211800

1.96842100

1.96839600

3.19454600

3.16972200

3.16974500
0.25677400

0.90183200

0.90196400

$-0.40565400$

$-0.54171400$

$-1.20273200$

$-1.20266900$

0.34576900

1.00777600

1.00776300

$-0.44426600$

$-1.10615500$

$-1.10613200$

0.44426700

1.10617200

1.10611500

$-0.34576900$

$-0.00000600$

$-1.00778000$

$-0.87936900$

$-1.00775900$

0.87937400

$0.54171400 \quad 0.00000300$

1.20270700

0.87890800

1.20269400

$-0.87891100$ 


$\begin{array}{lrrr}\mathrm{C} & 4.50381100 & -0.25677400 & 0.00002600 \\ \mathrm{H} & 4.57451800 & -0.90190500 & -0.88551500 \\ \mathrm{H} & 5.37826800 & 0.40565400 & 0.00003300 \\ \mathrm{H} & 4.57449600 & -0.90189200 & 0.88557900\end{array}$

$\mathrm{C}_{3} \mathrm{H}_{8}$

C

$\mathrm{H}$

$\mathrm{H}$

$\mathrm{H}$

C

$\mathrm{H}$

$\mathrm{H}$

C

$\mathrm{H}$

$\mathrm{H}$

$\mathrm{H}$

$\begin{array}{rrr}-1.27829500 & -0.26007500 & 0.00000000 \\ -1.32310500 & -0.90777100 & -0.88545000 \\ -1.32314900 & -0.90768400 & 0.88551200 \\ -2.17804800 & 0.36760800 & -0.00005300 \\ 0.00000000 & 0.58693500 & 0.00000000 \\ 0.00000000 & 1.24747600 & -0.87850000 \\ 0.00000000 & 1.24750700 & 0.87847800 \\ 1.27829500 & -0.26007500 & 0.00000100 \\ 2.17804800 & 0.36760800 & -0.00019400 \\ 1.32321500 & -0.90758200 & 0.88558300 \\ 1.32303900 & -0.90787300 & -0.88537900\end{array}$

TS-S1

C

$\mathrm{H}$

$\mathrm{H}$

$\mathrm{H}$

C

$\mathrm{H}$

$\mathrm{H}$

C

$\mathrm{H}$

$\mathrm{H}$

C
$-5.42983400$

$-5.74881000$

$-5.38052300$

$-6.21263700$

$-4.07491500$

$-4.16622000$

$-3.79991800$

$-2.94720400$

$-2.85602500$

$-3.22417000$

$-1.58738300$
$-0.51822000$

$-0.22758600$

$0.51685200-0.40666400$

$-1.02205100 \quad-1.20170600$

$-1.01045100 \quad 0.36232400$

$-0.56429400 \quad 0.48899000$

$-0.08469100 \quad 1.47470400$

$-1.61125700 \quad 0.68385400$

$0.11504100 \quad-0.30023500$

$-0.36619200 \quad-1.28623600$

$1.16225100-0.49737500$

0.07547600

0.41042200 


\begin{tabular}{|c|c|c|c|}
\hline $\mathrm{H}$ & -1.31227400 & -0.97158500 & 0.60869800 \\
\hline $\mathrm{H}$ & -1.67933200 & 0.55831800 & 1.39556400 \\
\hline $\mathrm{C}$ & -0.45956600 & 0.75216600 & -0.38091500 \\
\hline $\mathrm{H}$ & -0.73551300 & 1.79866700 & -0.58308900 \\
\hline $\mathrm{H}$ & -0.36535300 & 0.26581000 & -1.36384100 \\
\hline $\mathrm{C}$ & 0.89861300 & 0.71444900 & 0.33244200 \\
\hline $\mathrm{H}$ & 1.17397200 & -0.33036200 & 0.53325000 \\
\hline $\mathrm{H}$ & 0.80821800 & 1.20603900 & 1.31346200 \\
\hline $\mathrm{C}$ & 2.02620000 & 1.38888500 & -0.46383000 \\
\hline $\mathrm{H}$ & 1.72748900 & 2.42692900 & -0.69412900 \\
\hline $\mathrm{H}$ & 2.13060800 & 0.88893500 & -1.43858300 \\
\hline $\mathrm{C}$ & 3.36218800 & 1.39364400 & 0.25202200 \\
\hline $\mathrm{H}$ & 4.18822800 & 1.83728600 & -0.31298900 \\
\hline $\mathrm{H}$ & 3.33350800 & 1.77264400 & 1.27917400 \\
\hline $\mathrm{C}$ & 4.14679500 & -1.20755700 & 0.51812900 \\
\hline $\mathrm{H}$ & 5.23873500 & -1.18291700 & 0.63286500 \\
\hline $\mathrm{H}$ & 3.64525600 & -1.58949600 & 1.40896400 \\
\hline $\mathrm{O}$ & 3.70439400 & -1.94294000 & -0.59089400 \\
\hline $\mathrm{H}$ & 4.21978800 & -1.68976100 & -1.37172700 \\
\hline $\mathrm{H}$ & 3.77046200 & 0.07101000 & 0.41399500 \\
\hline
\end{tabular}

\section{TS-S2}

C

$\mathrm{H}$

$\mathrm{H}$

$\mathrm{H}$

C

$\mathrm{H}$

$\mathrm{H}$

C
5.60860400

5.92780400

5.62343800

6.35887200

4.21332100

4.23938600

3.93820500

3.12846400
0.49606200

$-0.23230700$

$-0.53181700 \quad-0.01597200$

$0.62437200-1.32241400$

$1.17382100 \quad 0.19280200$

0.77491400

0.33929800

$0.67142500 \quad 1.43406400$

1.82072600

0.13853900

$-0.15011700 \quad-0.22955200$ 


$\begin{array}{lrrr}\mathrm{H} & 3.10392700 & -0.04703100 & -1.32530300 \\ \mathrm{H} & 3.40454100 & -1.19686500 & -0.02847700 \\ \mathrm{C} & 1.72812900 & 0.12315900 & 0.33611100 \\ \mathrm{H} & 1.45256800 & 1.16922800 & 0.13366200 \\ \mathrm{H} & 1.75347800 & 0.02128400 & 1.43192000 \\ \mathrm{C} & 0.64417400 & -0.80269600 & -0.23305600 \\ \mathrm{H} & 0.91644600 & -1.84945200 & -0.02650700 \\ \mathrm{H} & 0.62225100 & -0.70358600 & -1.32896800 \\ \mathrm{C} & -0.75627800 & -0.51998300 & 0.32667300 \\ \mathrm{H} & -1.03592500 & 0.52061700 & 0.11295500 \\ \mathrm{H} & -0.73757100 & -0.61697500 & 1.42299100 \\ \mathrm{C} & -1.83571200 & -1.45340700 & -0.24139400 \\ \mathrm{H} & -1.56426600 & -2.50109400 & -0.01873200 \\ \mathrm{H} & -1.85527200 & -1.37794100 & -1.33787500 \\ \mathrm{C} & -3.22170100 & -1.19472100 & 0.30629600 \\ \mathrm{H} & -4.01420400 & -1.82418100 & -0.10910600 \\ \mathrm{H} & -3.28607900 & -1.11986900 & 1.39683600 \\ \mathrm{H} & -3.55607800 & -0.00197100 & -0.10004700 \\ \mathrm{H} & -3.88632700 & 1.11215300 & -0.49135500 \\ \mathrm{H} & -5.13697400 & 1.43053300 & 0.07116000 \\ \mathrm{H} & -5.39392300 & 2.42861500 & -0.31091800 \\ \mathrm{H} & -5.93222900 & 0.73469600 & -0.23840000 \\ \mathrm{H} & -5.10692100 & 1.48630800 & 1.17041200\end{array}$

TS-S3

$\begin{array}{lrrr}\mathrm{C} & -1.05701700 & -0.03474400 & 0.49096600 \\ \mathrm{H} & -1.36073000 & -0.12519200 & 1.54110400 \\ \mathrm{C} & 1.65082800 & -0.34994500 & 0.58180900 \\ \mathrm{H} & 2.00401300 & 0.18760800 & 1.47172000 \\ \mathrm{H} & 1.81947800 & -1.42596100 & 0.65060500\end{array}$




$\begin{array}{rrrr}\mathrm{O} & 2.20065000 & 0.11064500 & -0.62298200 \\ \mathrm{H} & 2.15802800 & 1.07857700 & -0.64644000 \\ \mathrm{H} & 0.29989900 & -0.20192100 & 0.57375000 \\ \mathrm{C} & -1.26736800 & 1.36119800 & -0.06174600 \\ \mathrm{H} & -2.33858400 & 1.60521400 & -0.14952300 \\ \mathrm{H} & -0.81422600 & 2.12715600 & 0.58123500 \\ \mathrm{H} & -0.83522800 & 1.45995800 & -1.06705900 \\ \mathrm{C} & -1.56487600 & -1.17252500 & -0.37170200 \\ \mathrm{H} & -1.11044800 & -1.14543800 & -1.37096600 \\ \mathrm{H} & -1.33965000 & -2.14975900 & 0.07289600 \\ \mathrm{H} & -2.65716400 & -1.11930900 & -0.50943400\end{array}$

TS-S4

C

$\mathrm{H}$

H

O

C

$\mathrm{H}$

$\mathrm{H}$

$\mathrm{H}$

C

$\mathrm{H}$

$\mathrm{H}$

H

C

$\mathrm{H}$

$\mathrm{H}$

$\mathrm{H}$

$\begin{array}{rrr}-0.88625300 & 0.04865400 & 0.41190000 \\ -0.73010600 & 0.08898100 & 1.49713600 \\ 0.26979100 & -0.29516400 & -0.01032300 \\ 1.40561200 & -0.64105700 & -0.43318200 \\ 2.37805100 & 0.16018900 & 0.18920600 \\ 3.34743000 & -0.17554100 & -0.20758500 \\ 2.26920100 & 1.22944600 & -0.05263500 \\ 2.40043000 & 0.03258500 & 1.28307400 \\ -1.78861700 & -1.09286300 & -0.01180300 \\ -1.81872000 & -1.19027800 & -1.10370200 \\ -1.45378200 & -2.04799800 & 0.40703300 \\ -2.81980800 & -0.91816500 & 0.33395800 \\ -1.18479700 & 1.40497300 & -0.19434900 \\ -0.44600200 & 2.15810500 & 0.10318800 \\ -1.20161400 & 1.35502500 & -1.28971200 \\ -2.17202200 & 1.76573900 & 0.13530100\end{array}$




\subsection{IRC analysis for TS1 and TS2}

To further identify the reasonability of the reaction pathway, the IRC analysis of TS1 and TS2 were conducted. These IRC analysis were taken using local quadratic approximation (LQA) method under uB3LYP/6-31+G(d), the same basis set with the structure optimization and the frequency analysis. For each transition state, 25 points were examined in each direction with step size of 15 (in unit of $0.01 \mathrm{Bohr}$ ).

Figure S2. IRC analysis for TS1 and TS2.

(a) IRC analysis of TS1

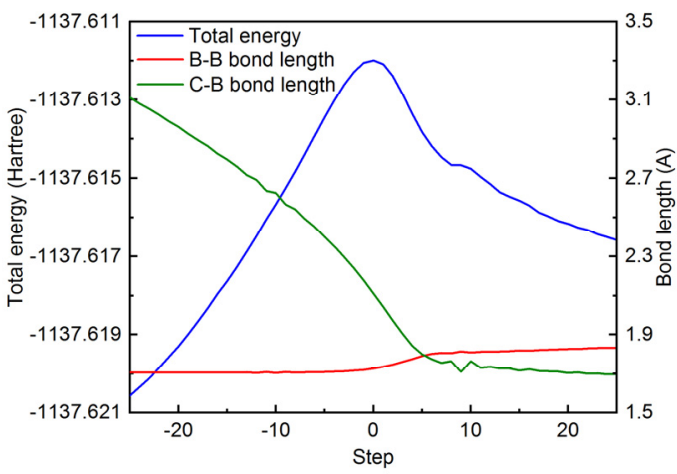

(b) IRC analysis of TS2

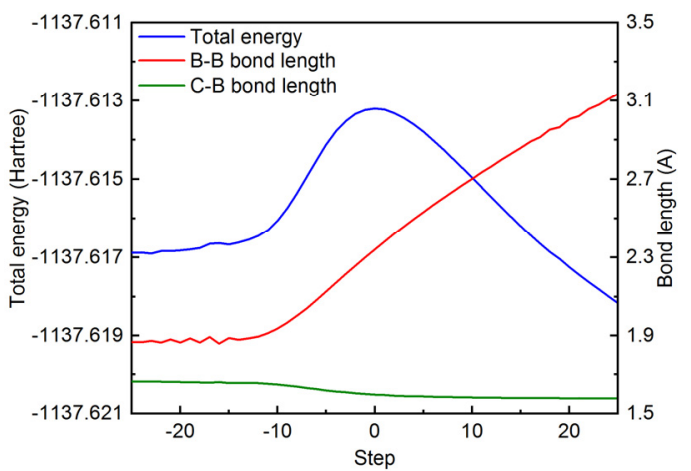

The energies, length of the C-B bond formed in the reaction and length of B-B bond broken in the reaction were shown in Figure S2.

Table S10. Comparison of bond length

\begin{tabular}{|l|l|l|}
\hline Structure & B-B bond length (A) & C-B bond length (A) \\
\hline$\bullet \mathrm{C}_{8} \mathrm{H}_{17}+\mathrm{B}_{2} \mathrm{pin}_{2}$ & 1.704 & None \\
\hline Step -25 of TS1 & 1.706 & 3.111 \\
\hline Step -10 of TS1 & 1.703 & 2.626 \\
\hline Step -5 of TS1 & 1.708 & 2.401 \\
\hline TS1 & 1.727 & 2.110 \\
\hline Step 5 of TS1 & 1.790 & 1.800 \\
\hline Step 10 of TS1 & 1.808 & 1.763 \\
\hline Step 25 of TS1 & 1.833 & 1.695 \\
\hline INT1 & 1.859 & 1.668 \\
\hline Step -25 of TS2 & 1.868 & 1.663 \\
\hline Step -10 of TS2 & 1.937 & 1.648 \\
\hline
\end{tabular}




\begin{tabular}{|l|l|l|}
\hline Step -5 of TS2 & 2.126 & 1.618 \\
\hline TS2 & 2.341 & 1.596 \\
\hline Step 5 of TS2 & 2.533 & 1.586 \\
\hline Step 10 of TS2 & 2.703 & 1.581 \\
\hline Step 25 of TS2 & 3.135 & 1.576 \\
\hline $\mathrm{C}_{8} \mathrm{H}_{17}$ Bpin $+\cdot$ Bpin & None & 1.573 \\
\hline
\end{tabular}

Furthermore, the bond length were carefully compared with the reactant $\left(\mathrm{B}_{2} \operatorname{pin}_{2}\right)$, the intermediate (INT 1), the product $\left(\mathrm{C}_{8} \mathrm{H}_{17} \mathrm{Bpin}\right)$ and the transition states (TS1, TS2) as shown in Table S10. It clearly represented the formation of the C-B bond and the breakage of the B-B bond form the reactant to INT1 through TS1, and further to the product through TS2. These results strongly identified the reasonability of the reaction pathway and the structure of TS1 and TS2. 
8. NMR charts

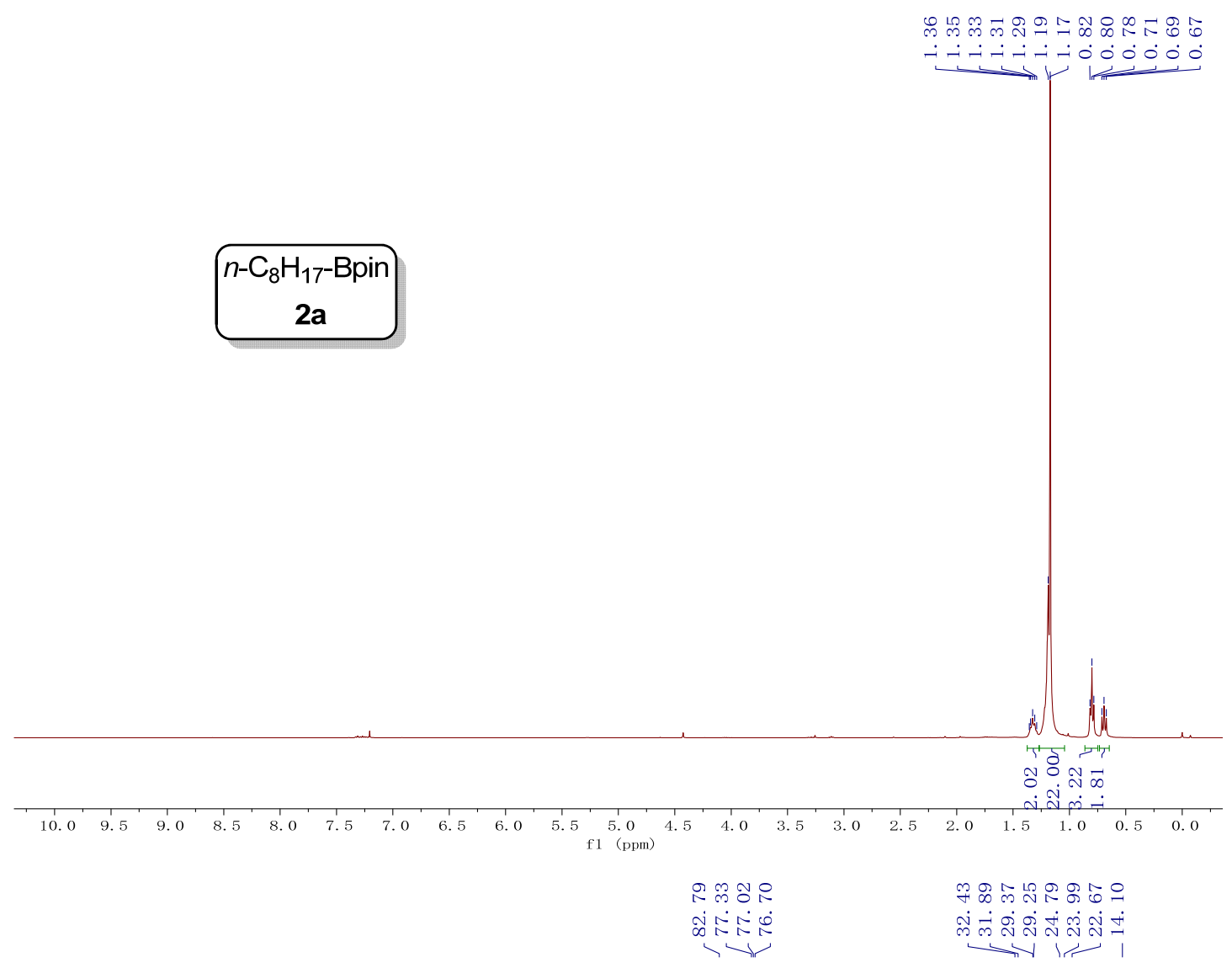

$n-\mathrm{C}_{8} \mathrm{H}_{17}-\mathrm{Bpin}$
$\mathbf{2 a}$

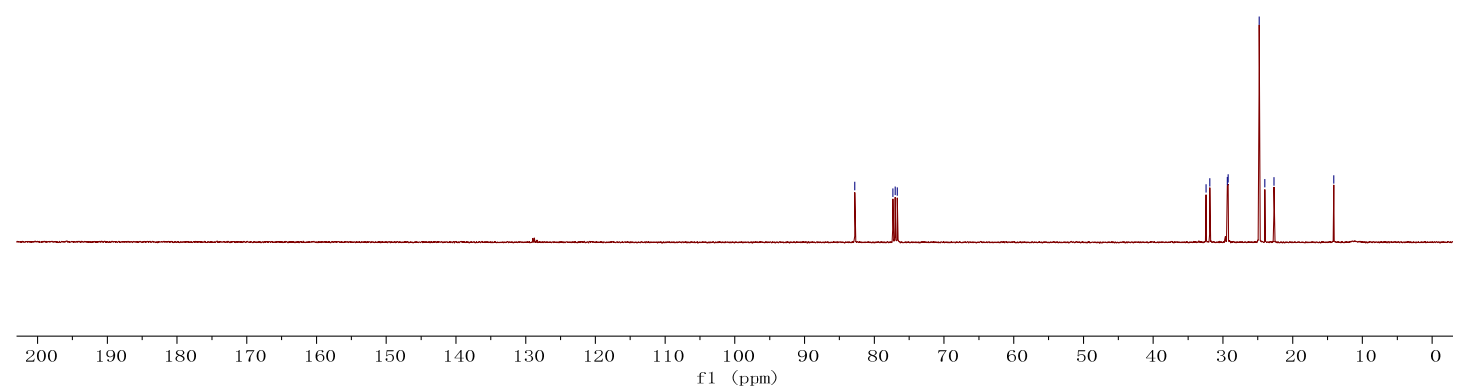




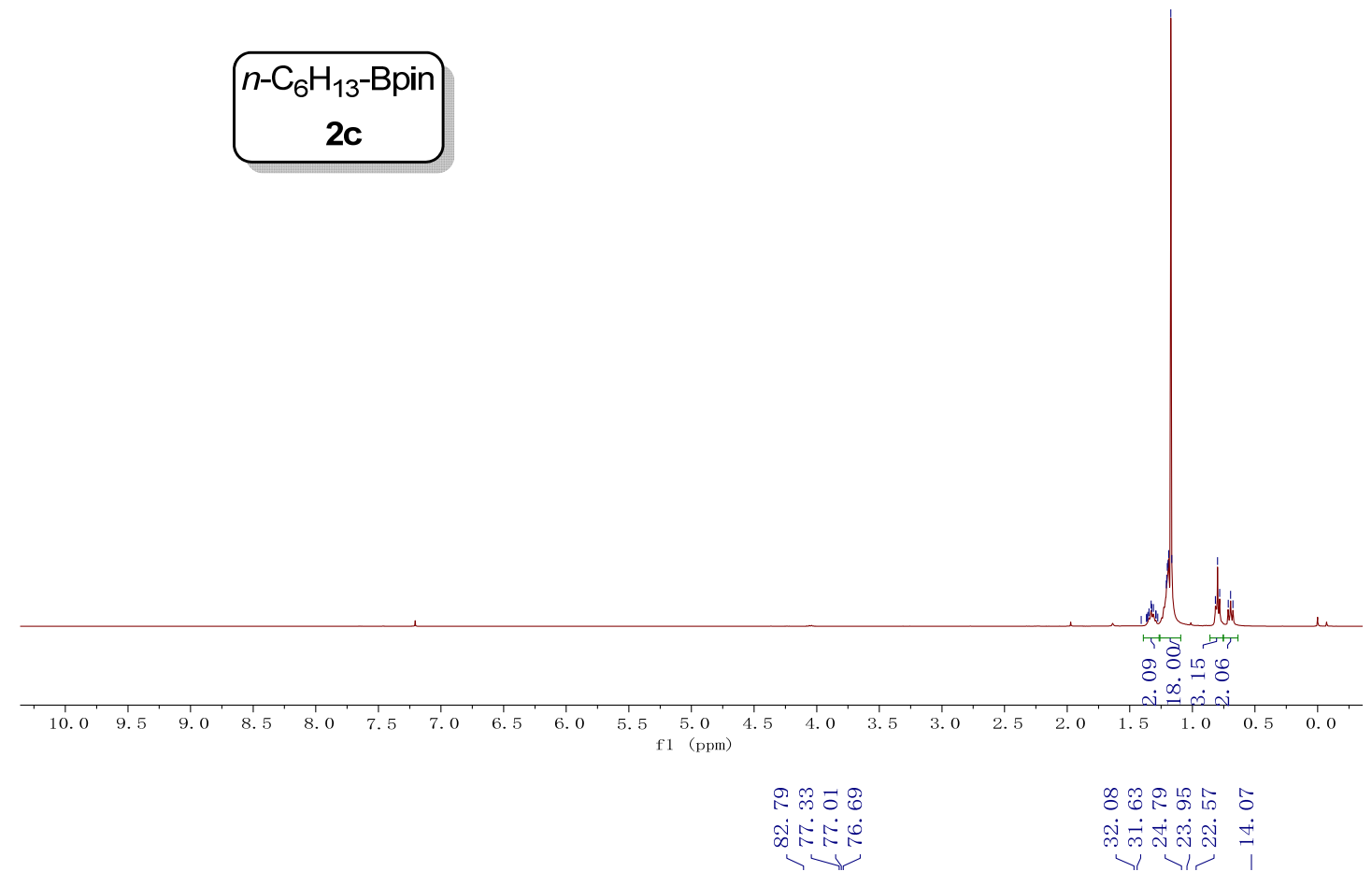

$n-\mathrm{C}_{6} \mathrm{H}_{13}-\mathrm{Bpin}$
$\mathbf{2 c}$

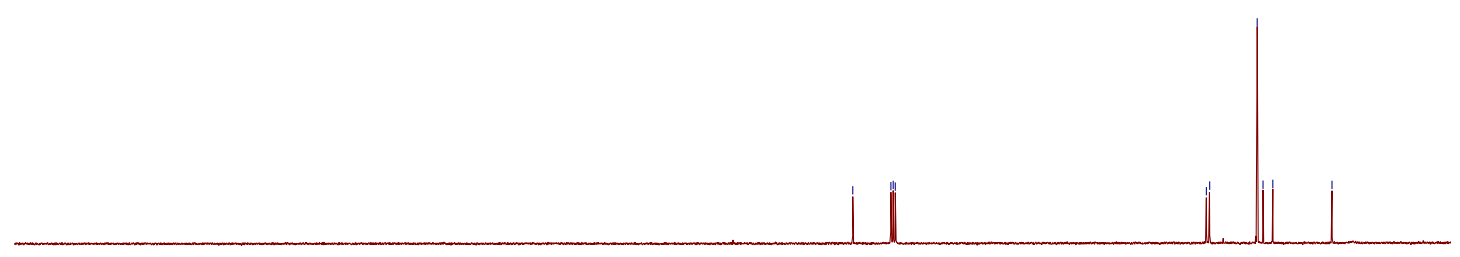

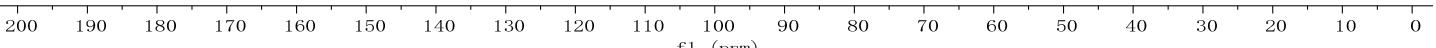




$n-\mathrm{C}_{9} \mathrm{H}_{19-\mathrm{Bpin}}$
$\mathbf{2 d}$

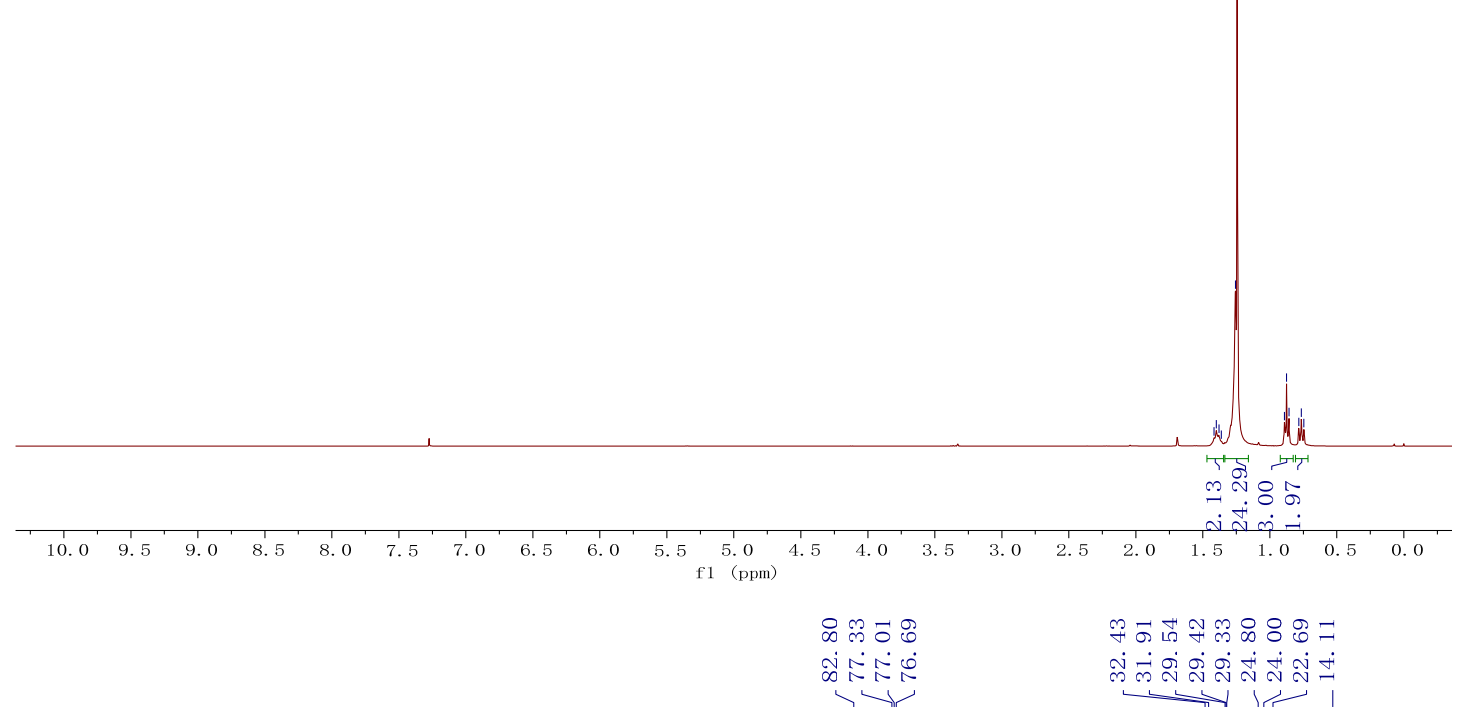

$n-\mathrm{C}_{9} \mathrm{H}_{19}-\mathrm{Bpin}$
$\mathbf{2 d}$

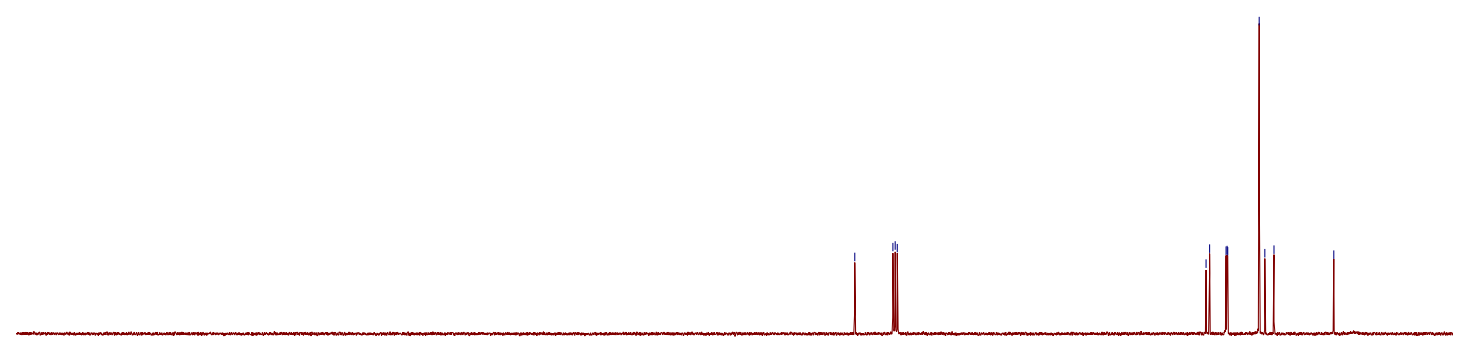

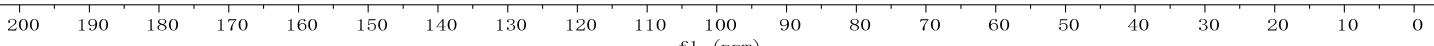




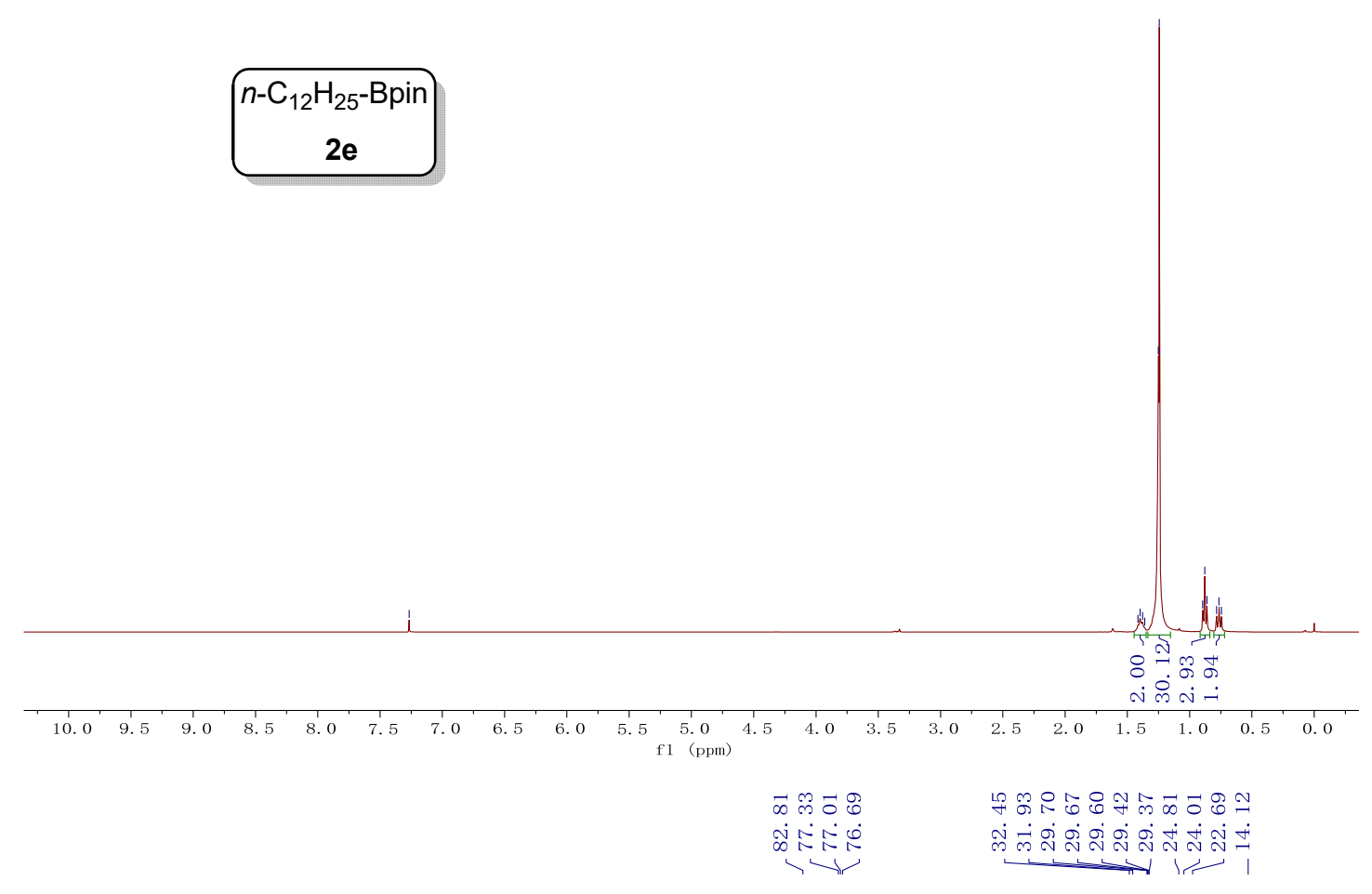

$n-\mathrm{C}_{12} \mathrm{H}_{25}$-Bpin

$2 e$

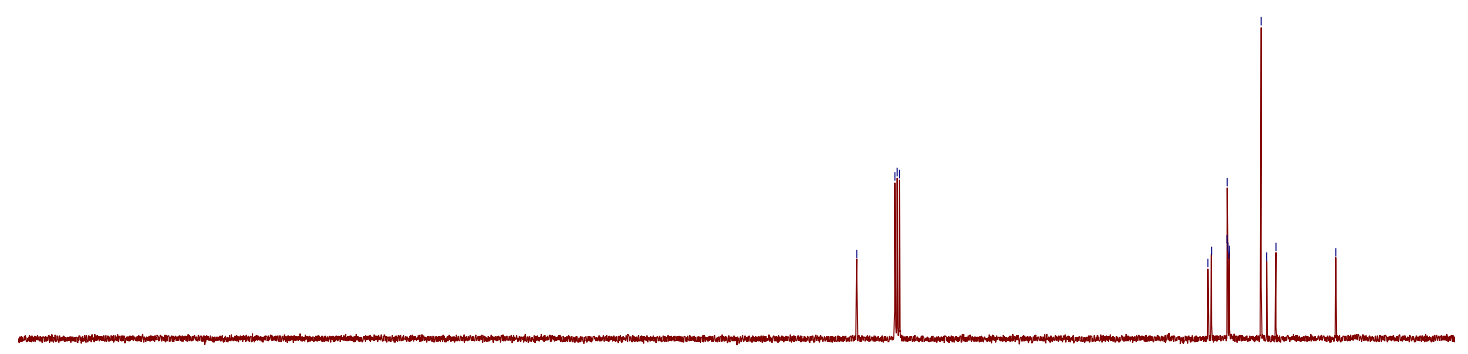

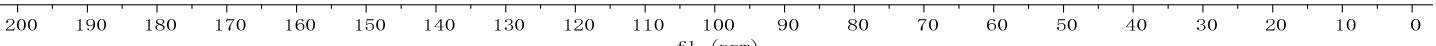



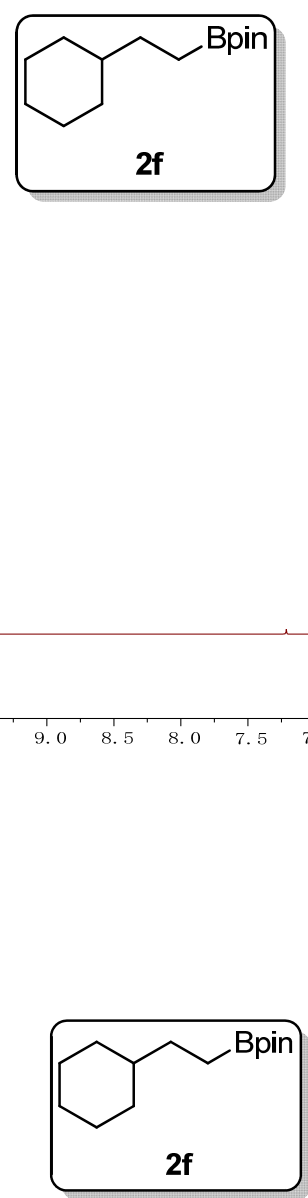

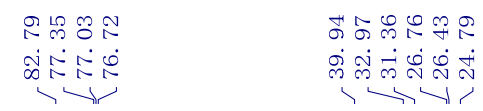

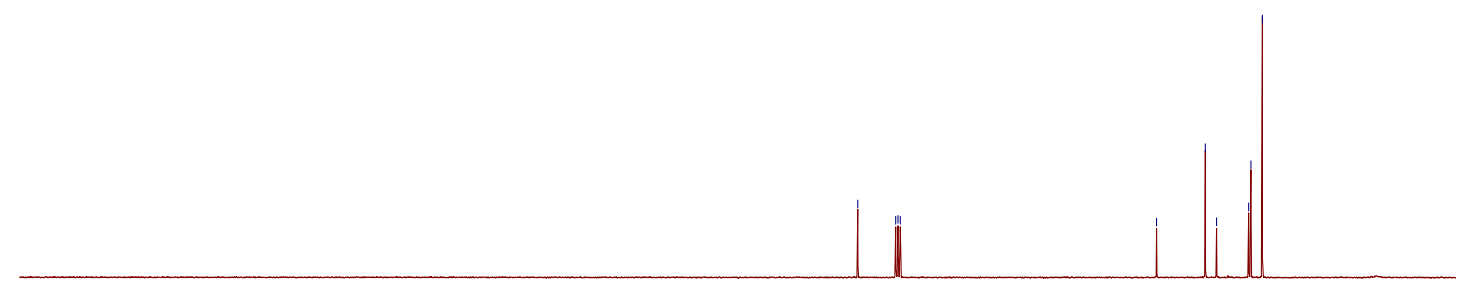

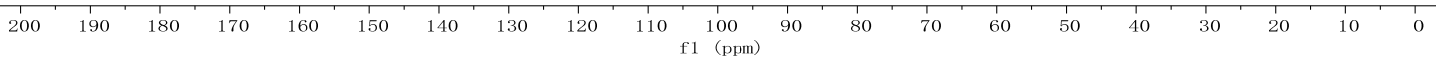



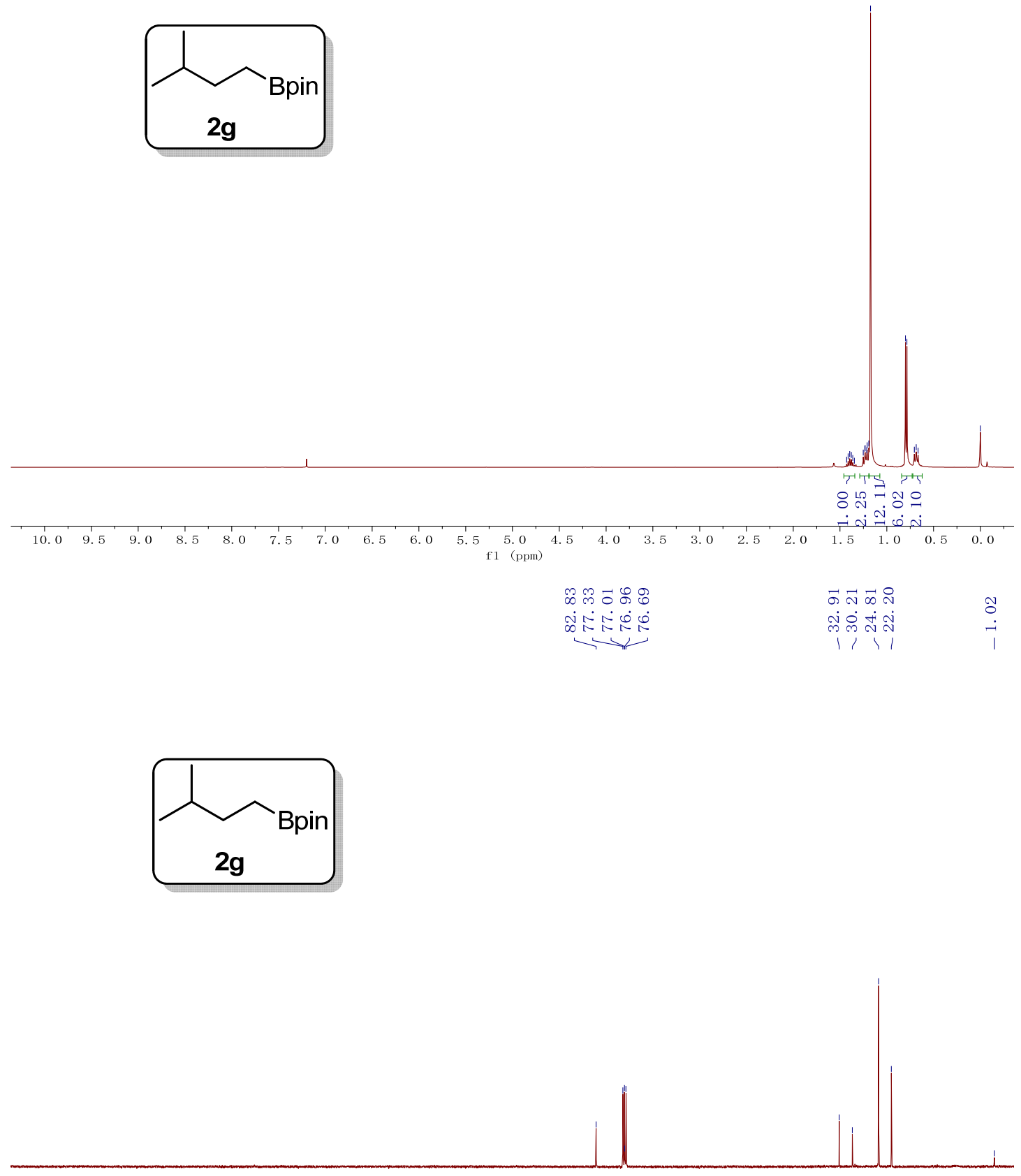

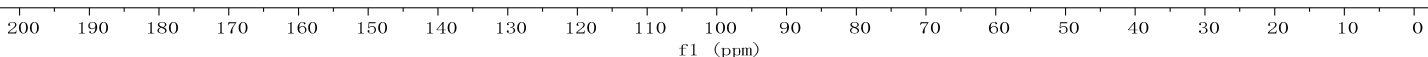



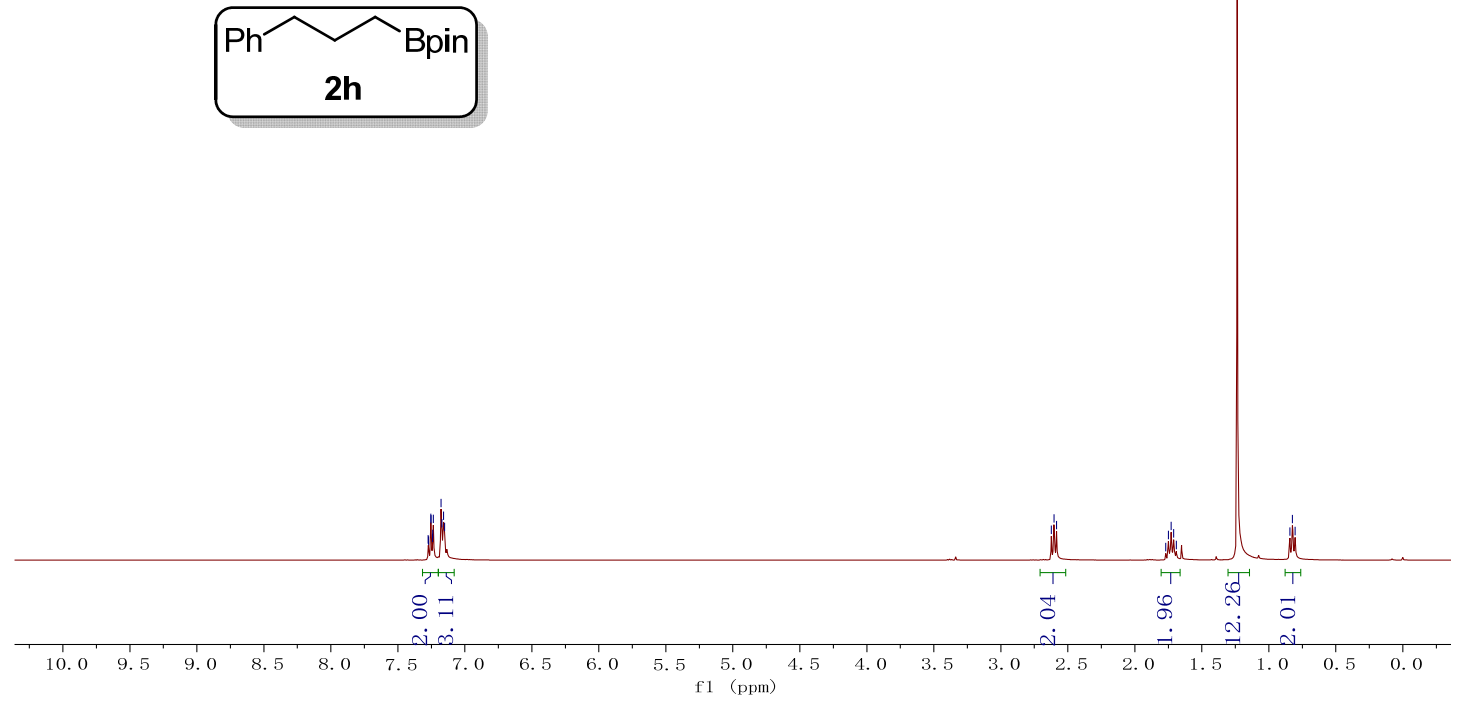

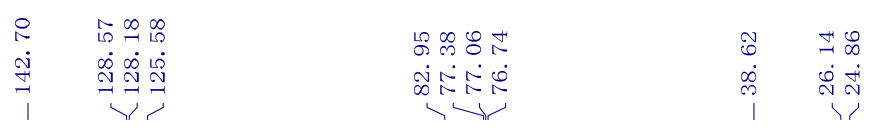
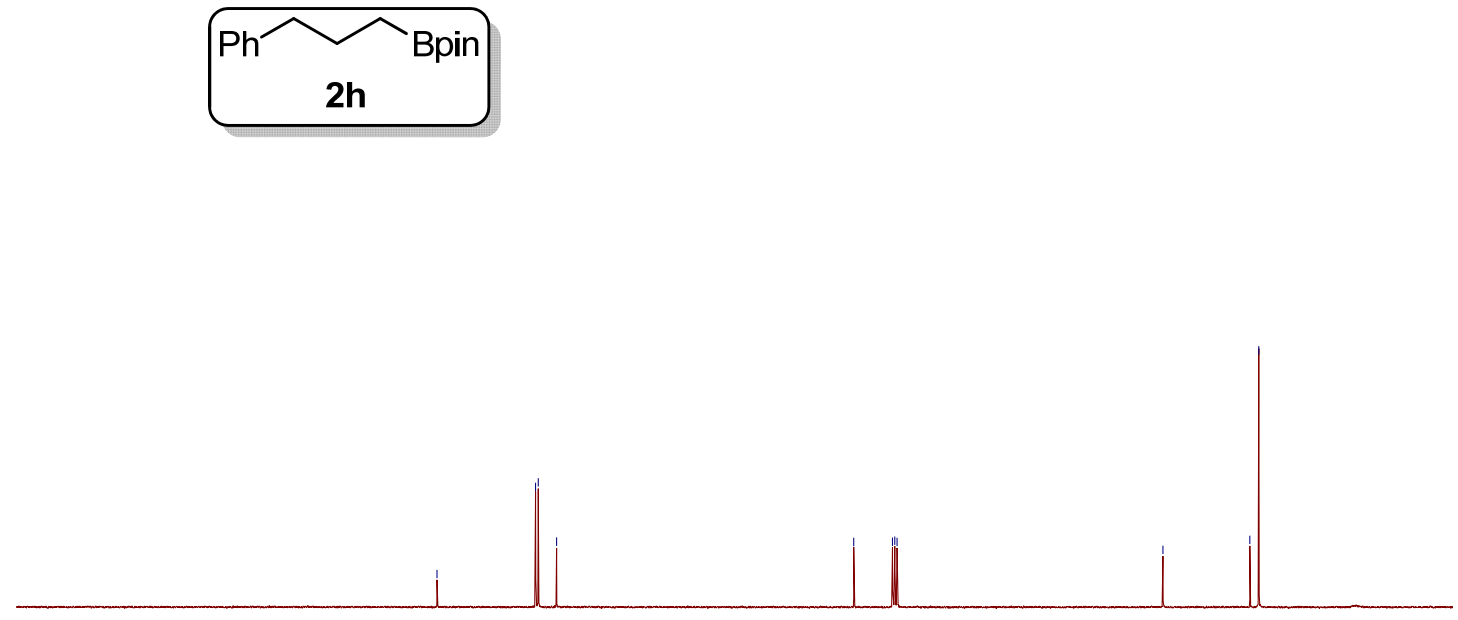

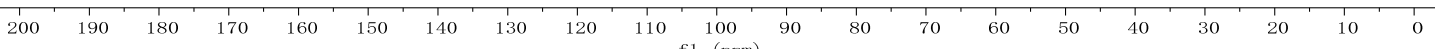



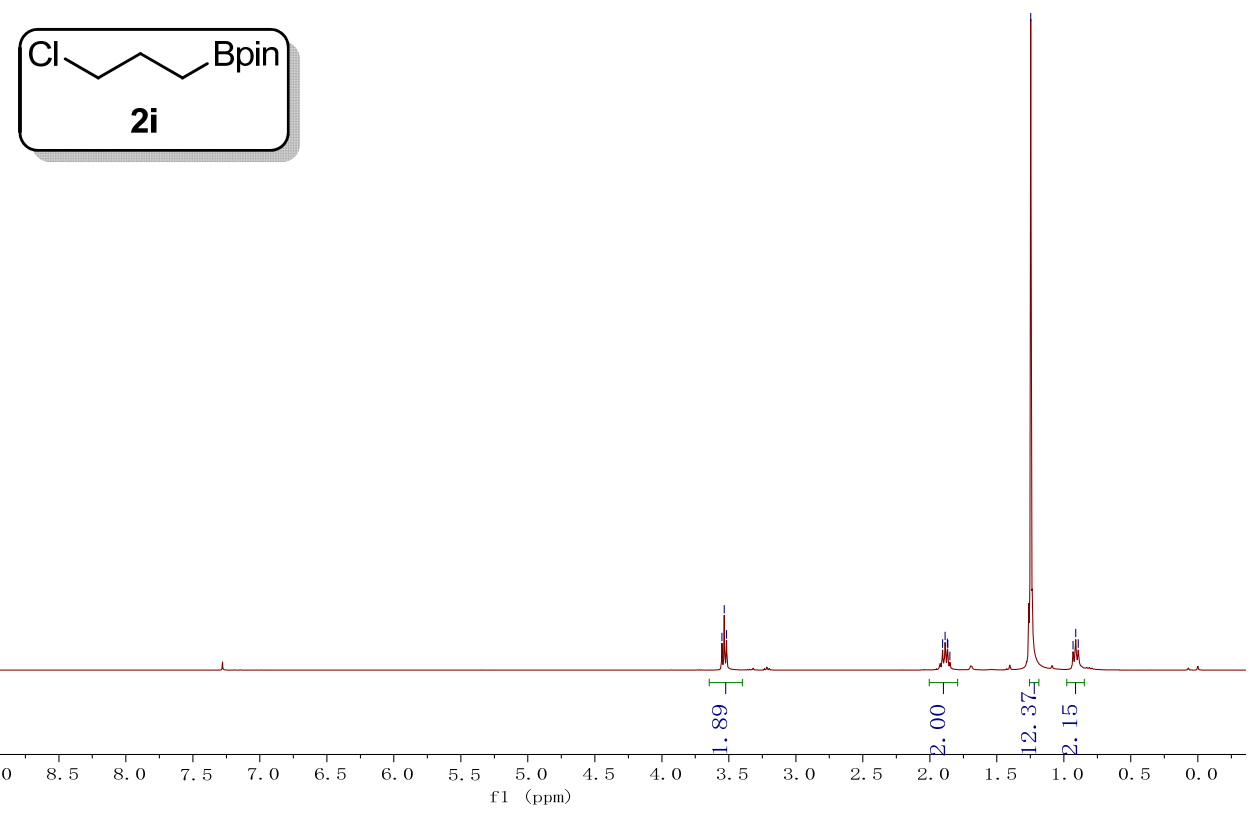

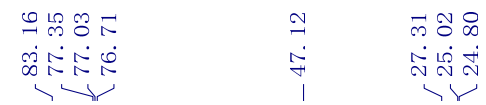
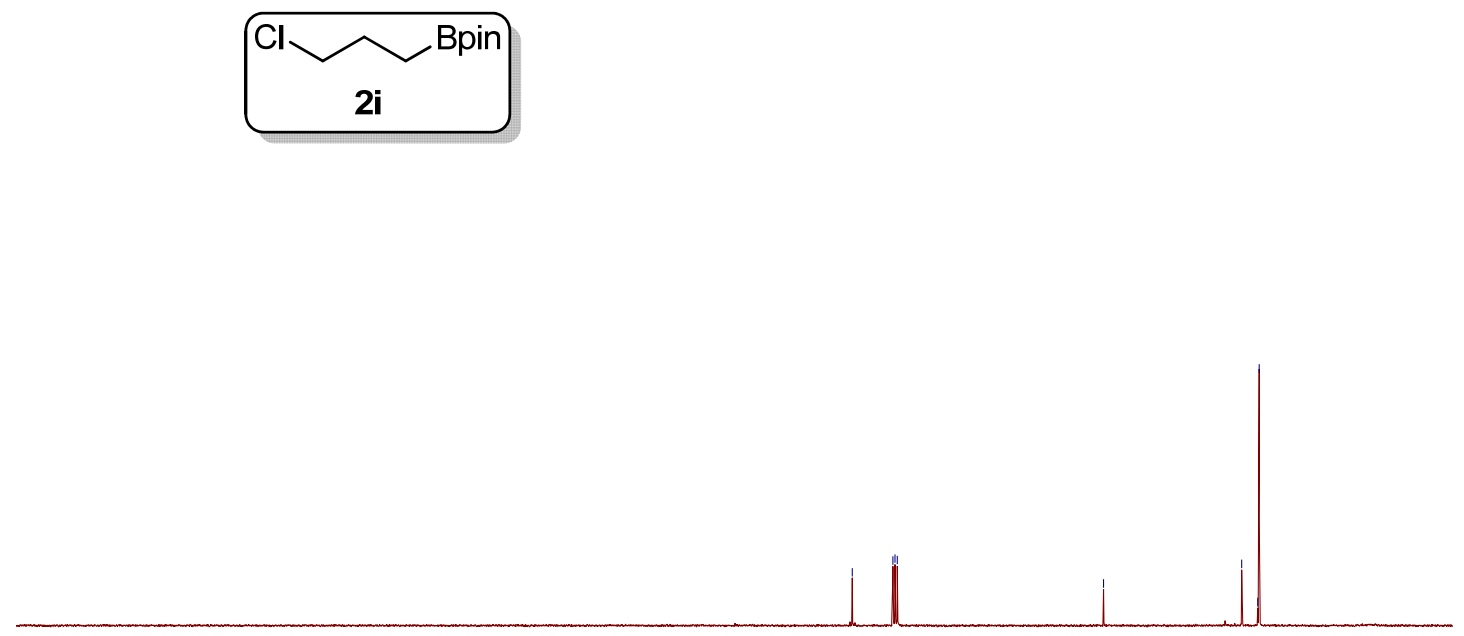

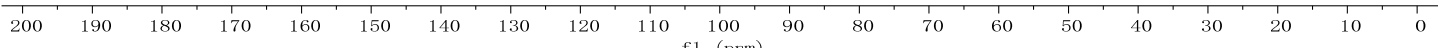



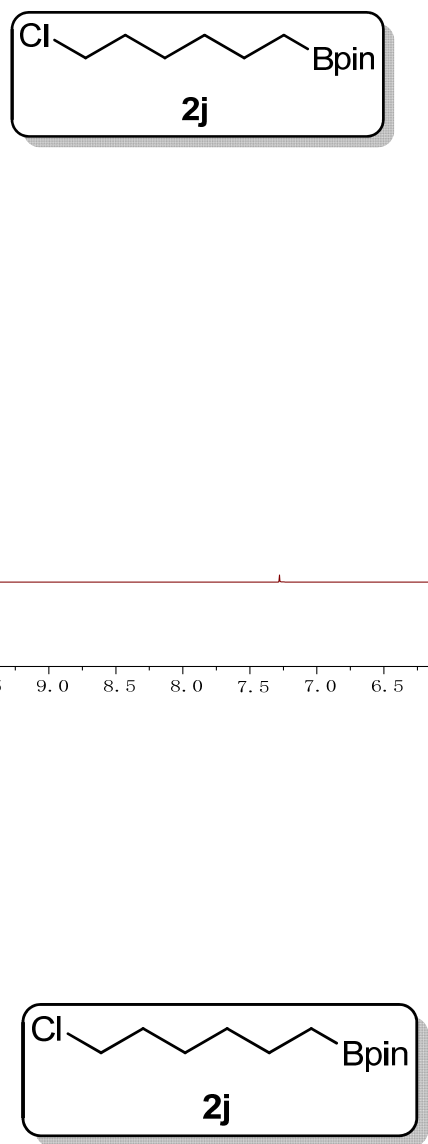

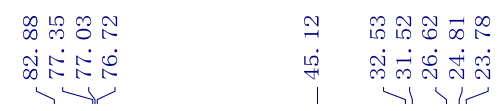

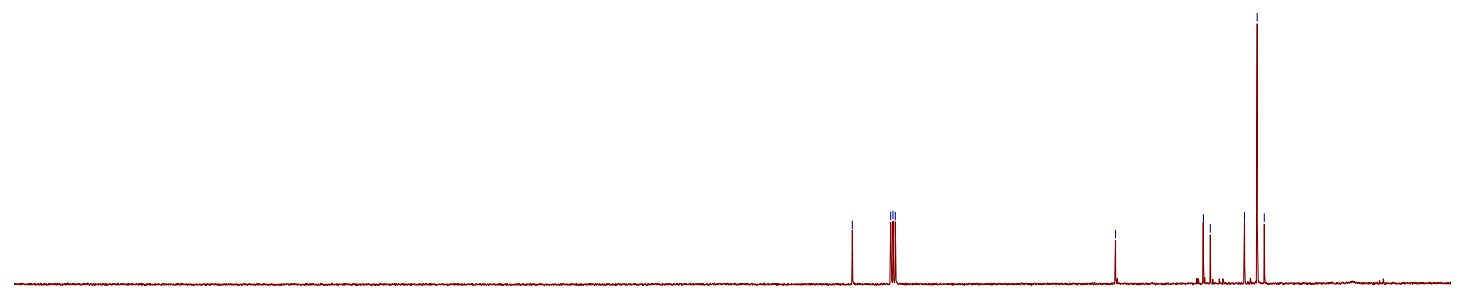

$\begin{array}{lllllllllllllllllllll}1 & 1 & 1 & 1 & 1 & 1 & 1 & 1 & 1 & 1 & 1 & 1 & 1 & 1 & 1 & 1 & 1 & 1 & 1 & 1 & 1 \\ 200 & 190 & 180 & 170 & 160 & 150 & 140 & 130 & 120 & 110 & 100 & 90 & 80 & 70 & 60 & 50 & 40 & 30 & 20 & 10 & 0\end{array}$ 


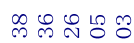

N几N几́

$\rightarrow 1$

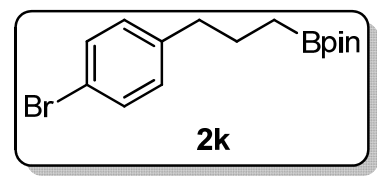

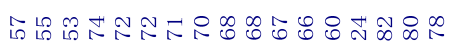

ง
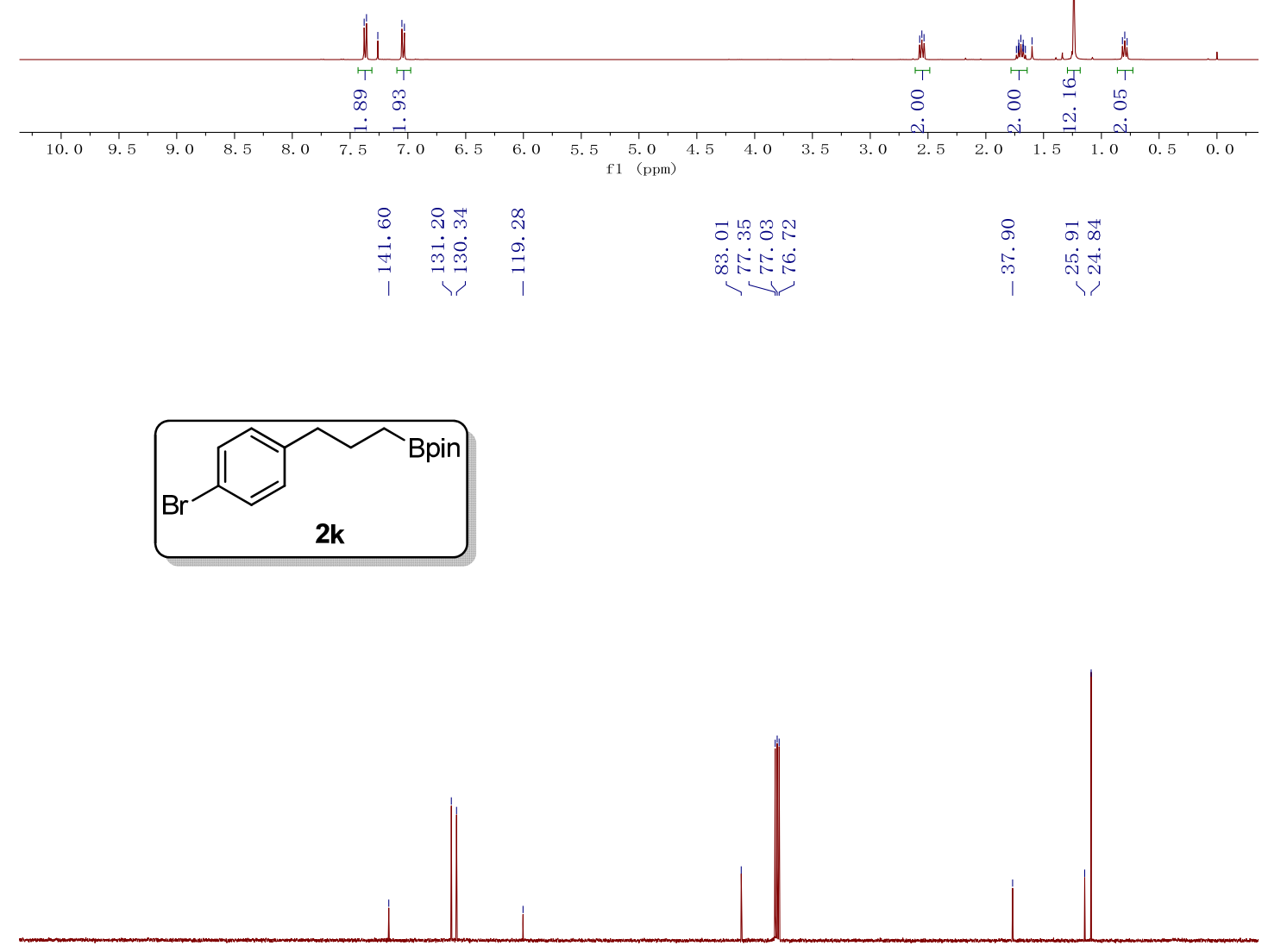

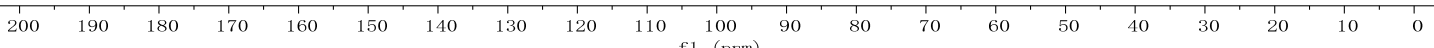




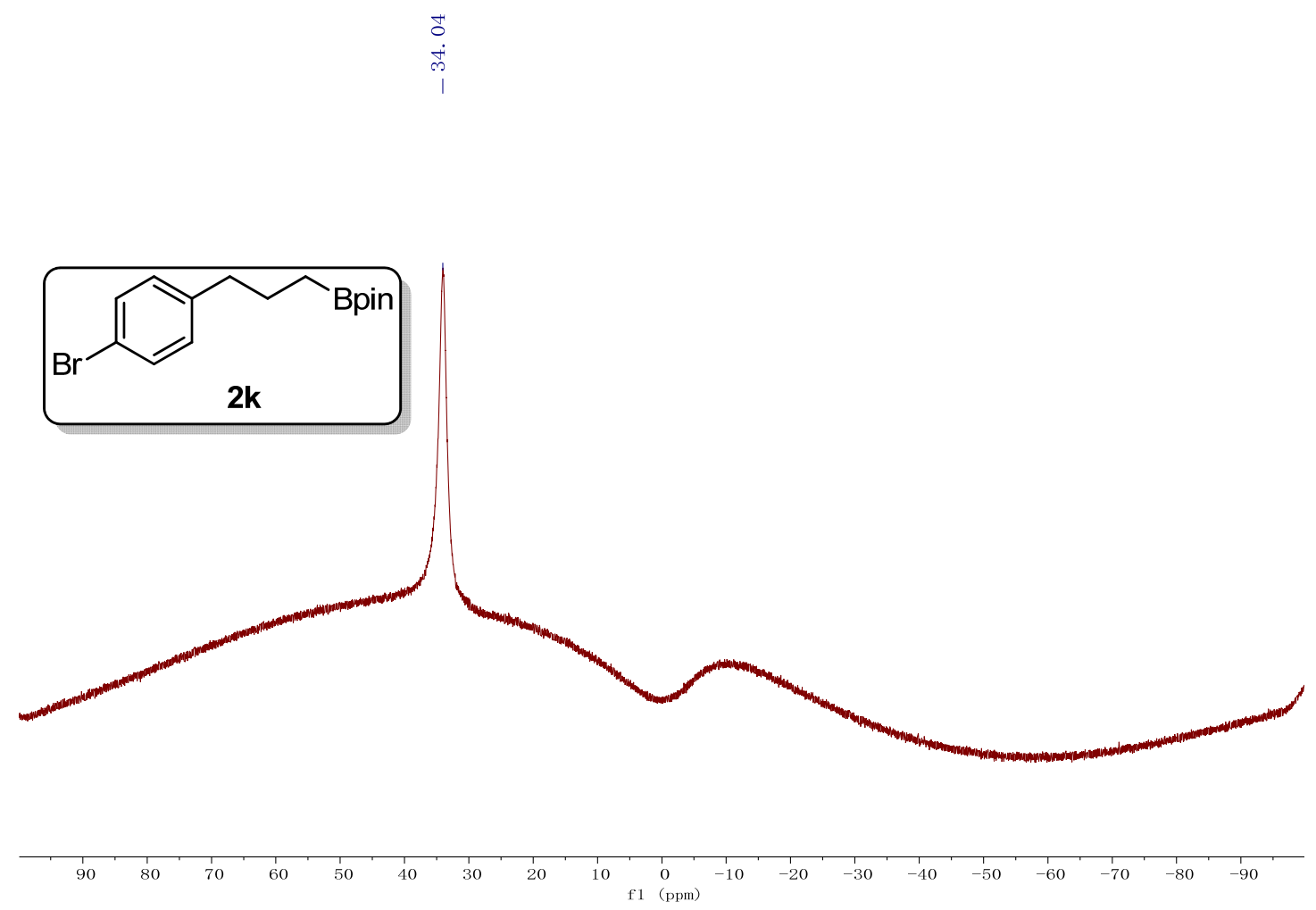



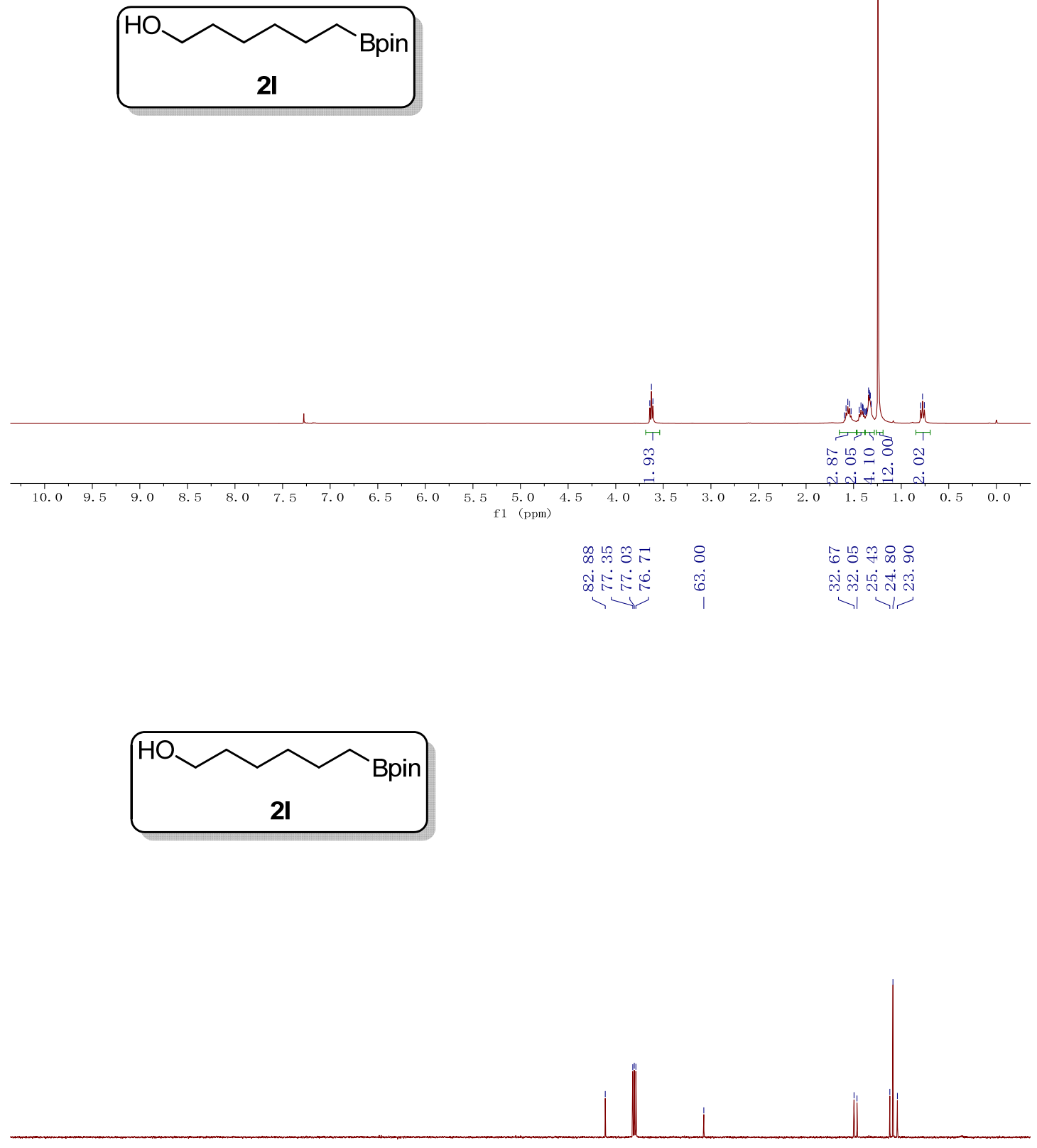

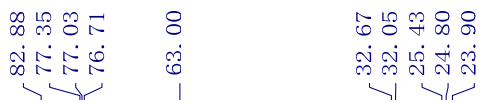

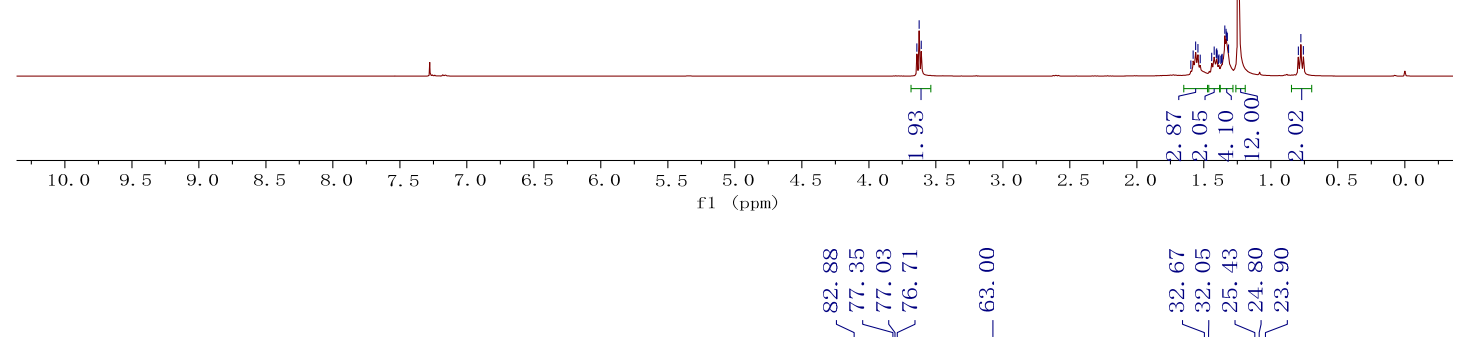

$200 \quad 190 \quad 180$

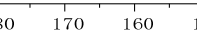

$150 \quad 140$

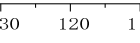

$110 \quad 100$

\begin{tabular}{lllllllll}
\hline 1 & 1 & 1 & 1 & 1 & 1 & 1 & 1 & 1 \\
& 70 & 60 & 50 & 40 & 30 & 20 & 10 & 0
\end{tabular} 


$$
\begin{aligned}
& \overrightarrow{0} \\
& \dot{m} \\
& 1
\end{aligned}
$$

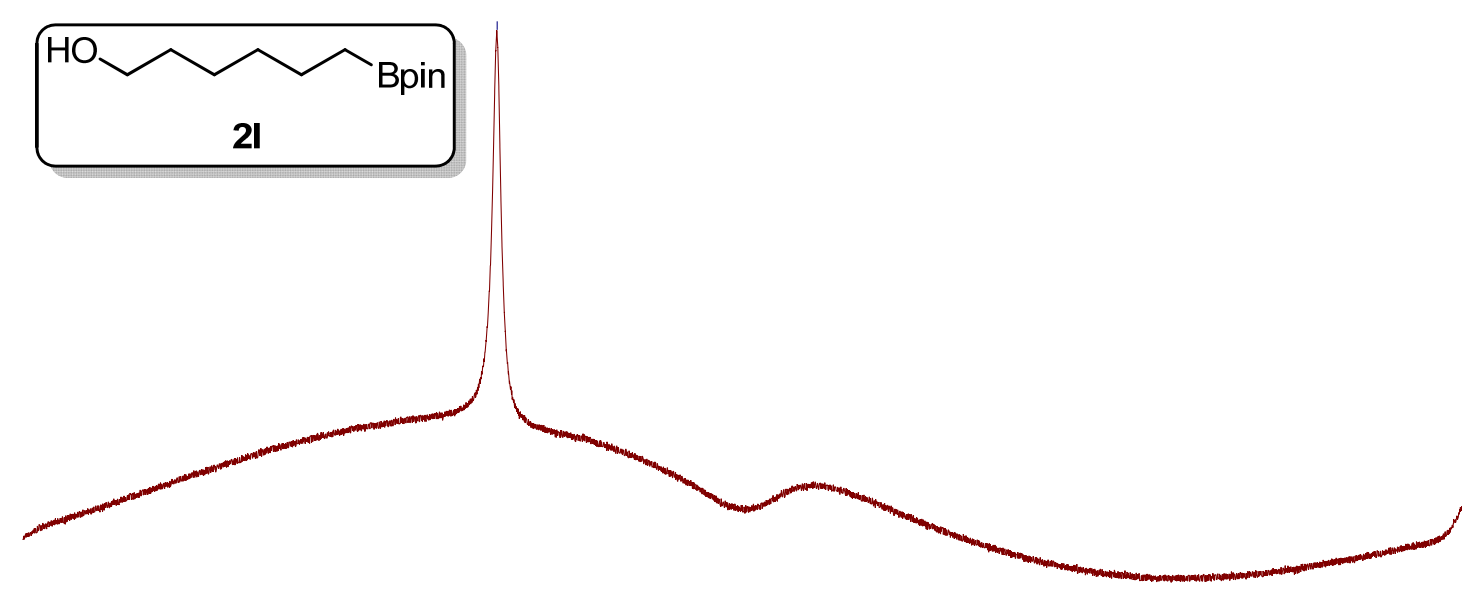

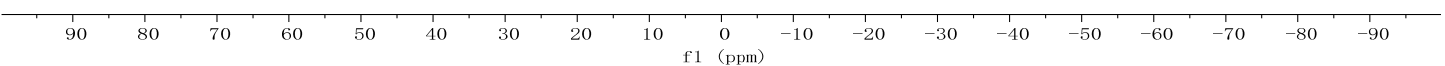



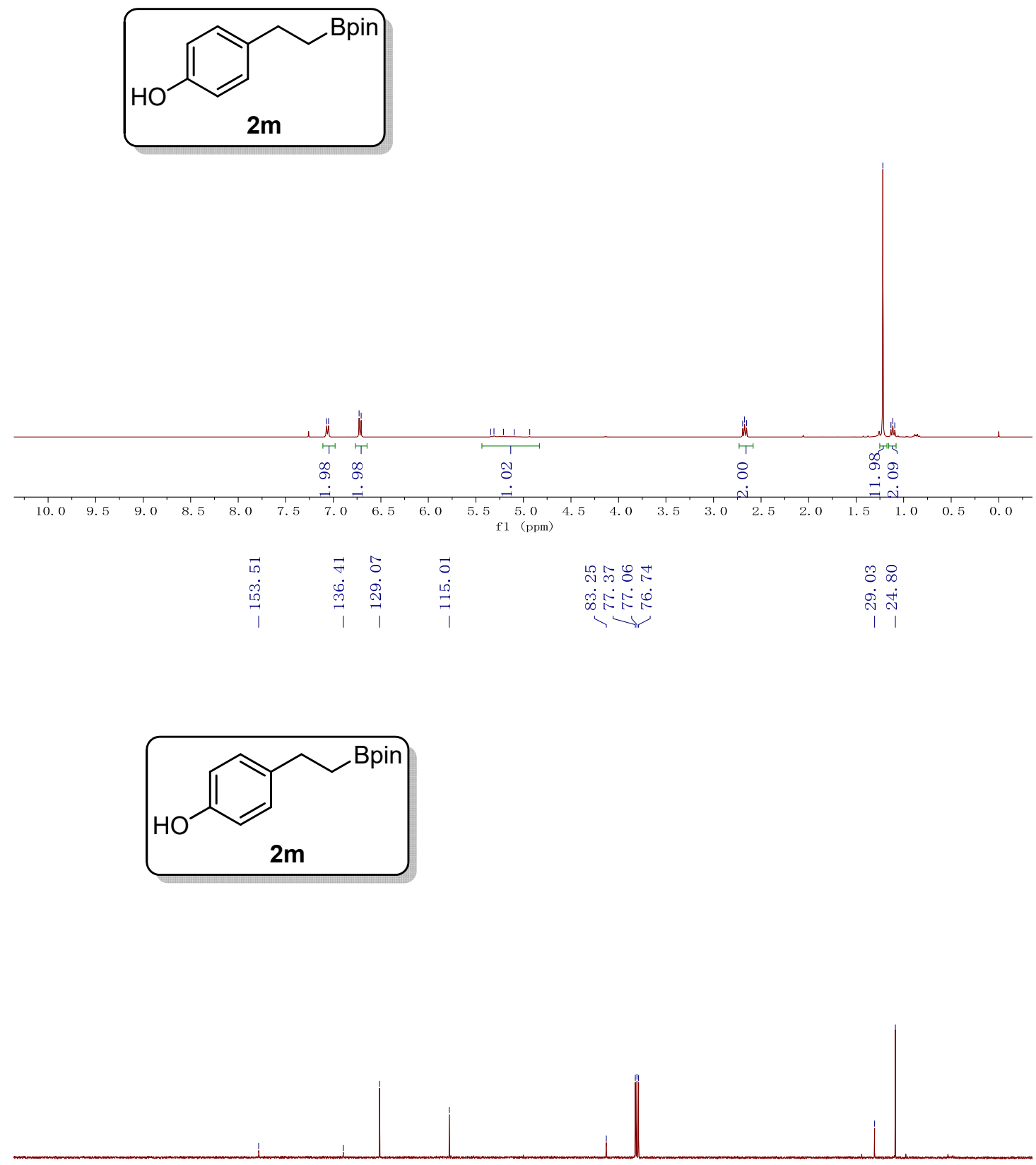

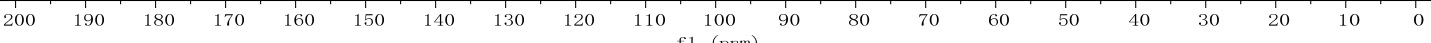




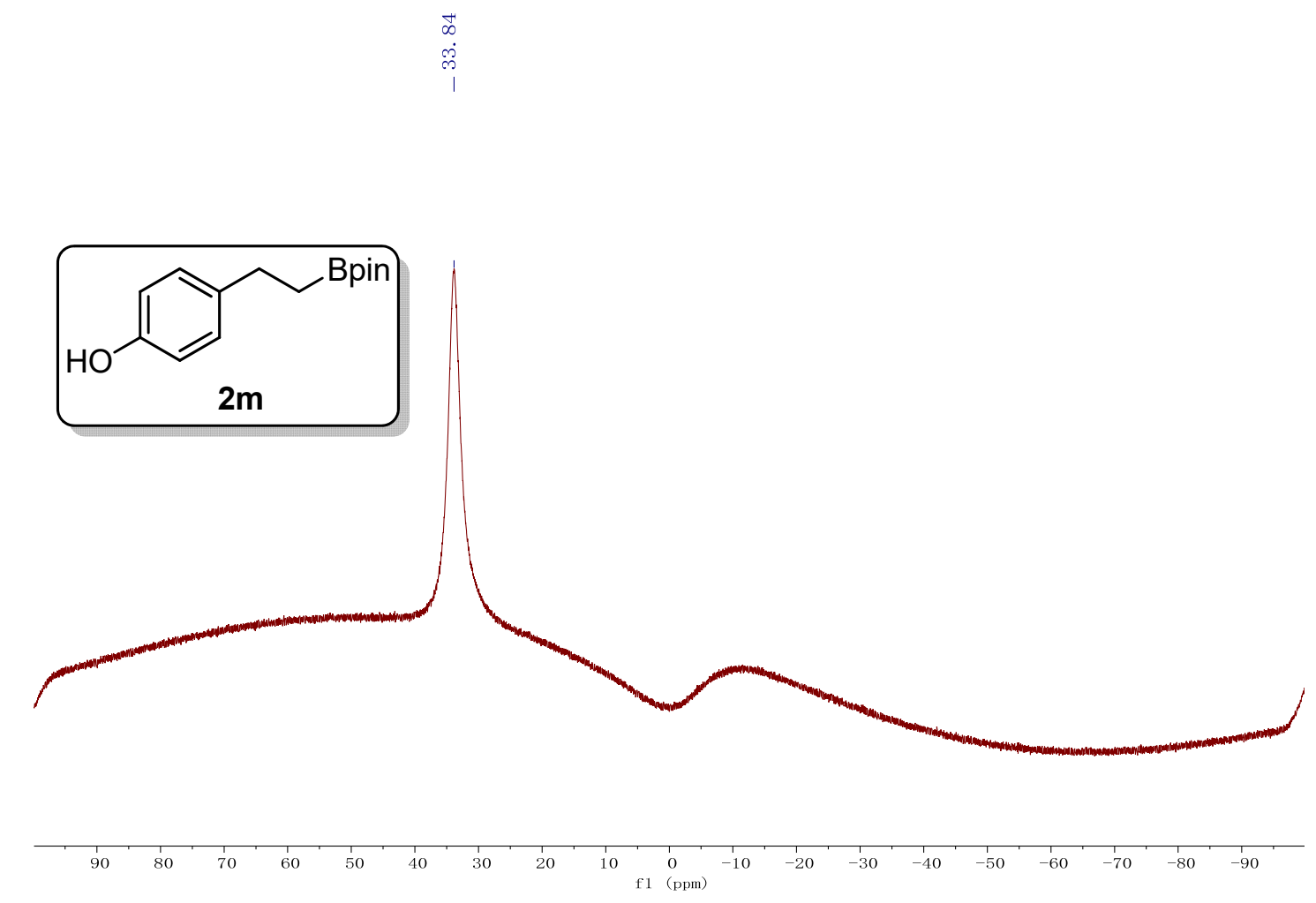




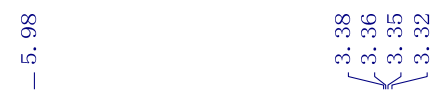

$\mathrm{MeO} ح$ Bpin

2n

Crude product

$\mathrm{C}_{2} \mathrm{H}_{2} \mathrm{Cl}_{4}(49.2 \mathrm{mg})$ added

में लं

(

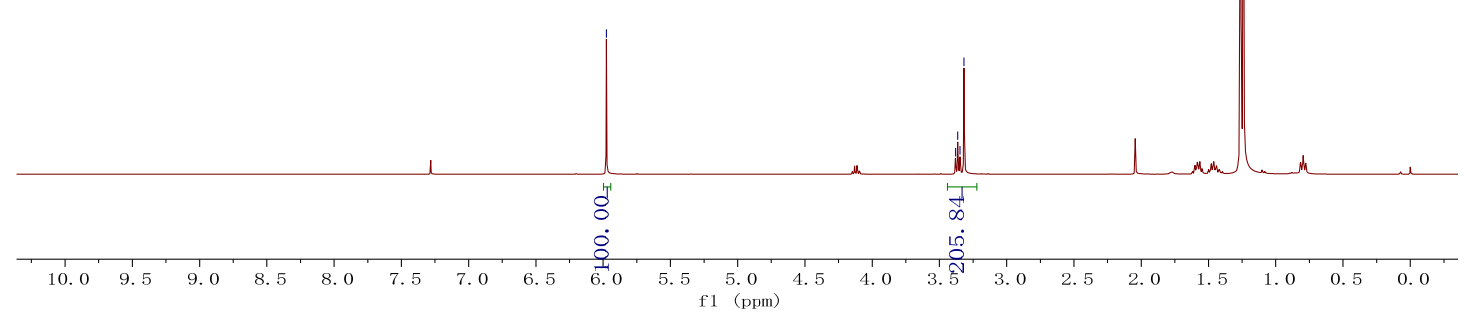




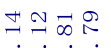

ヘ்

\section{ミ $\quad$ 요}

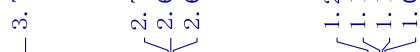

ำ
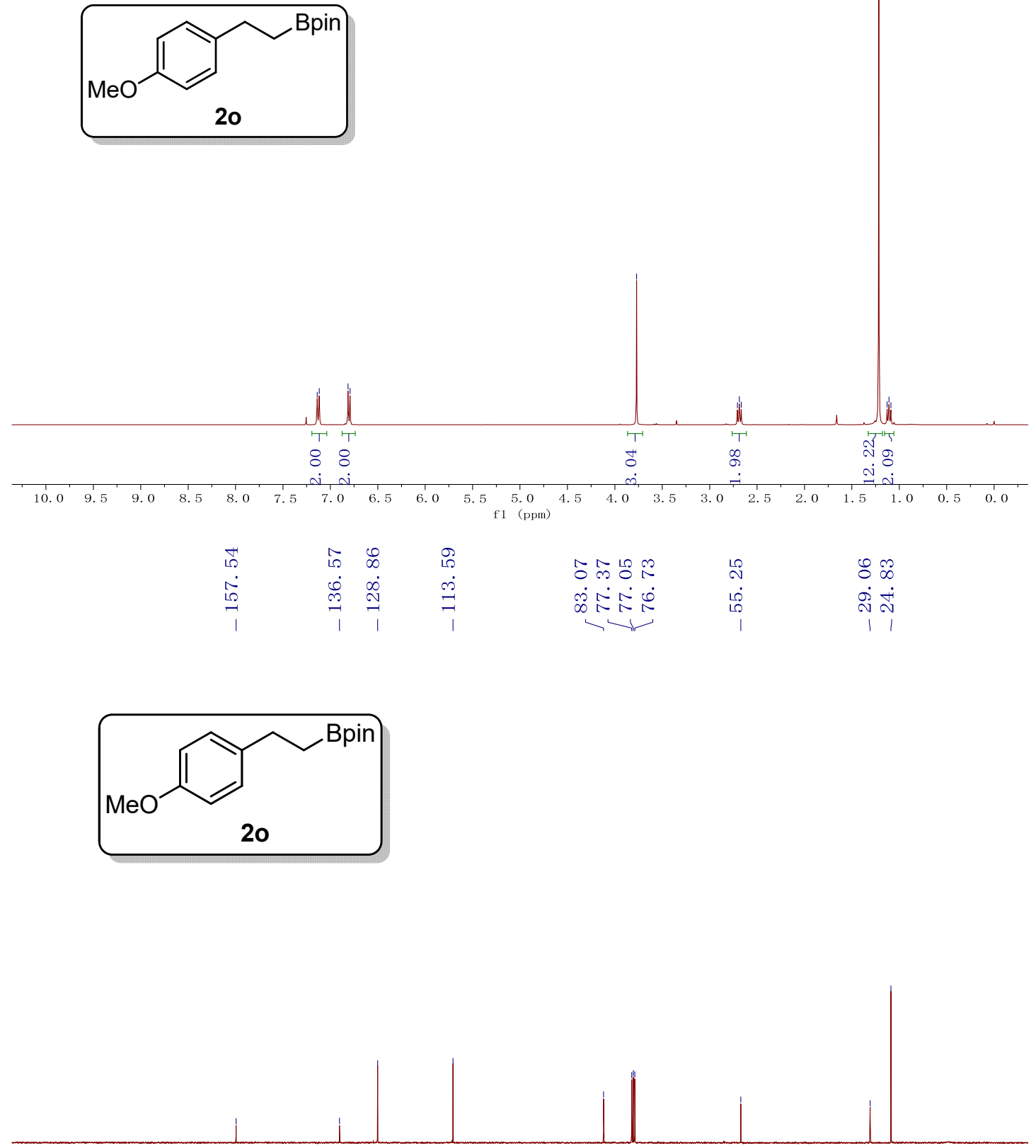

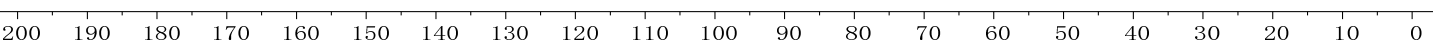
f1 (ppm) 

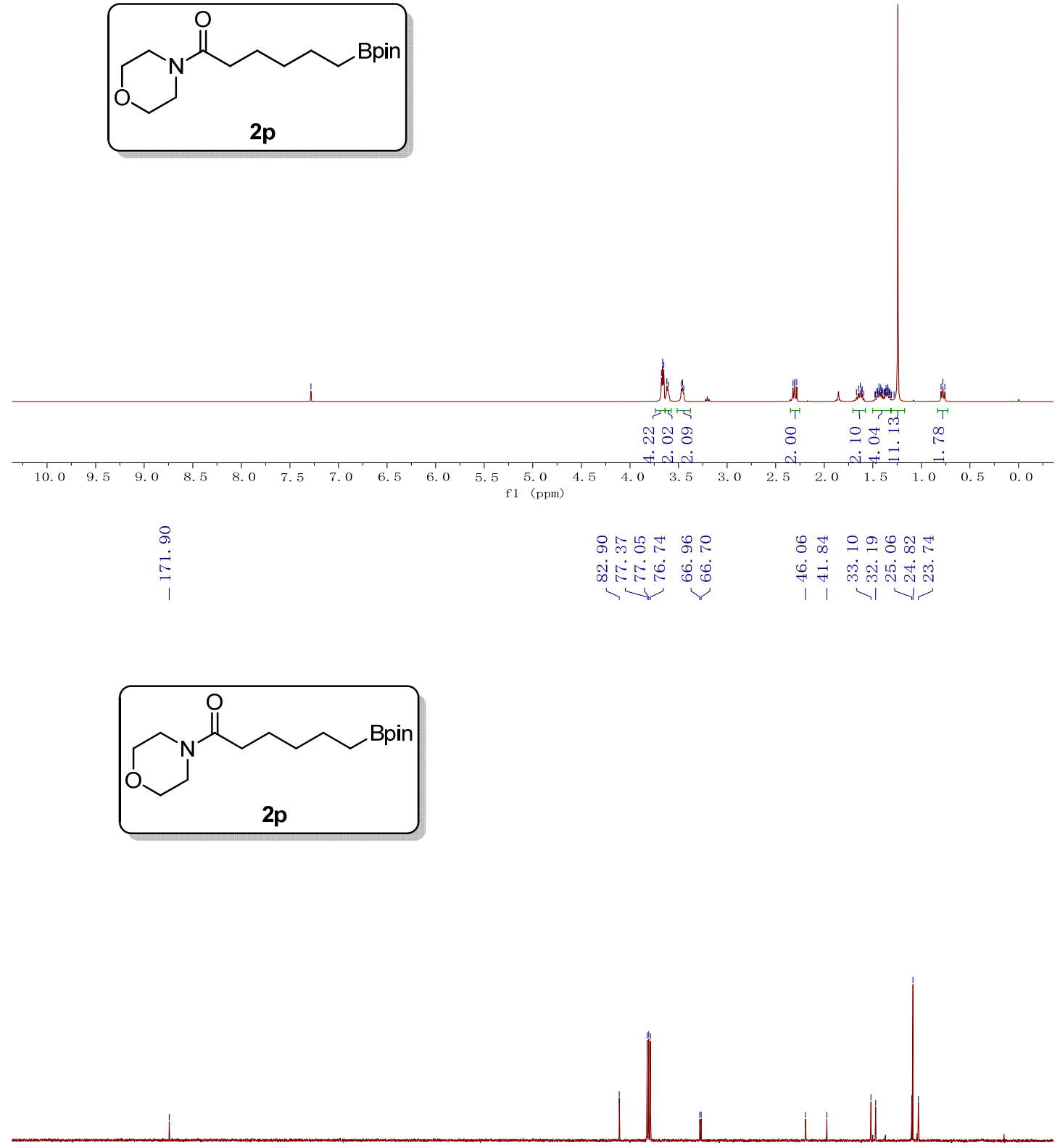

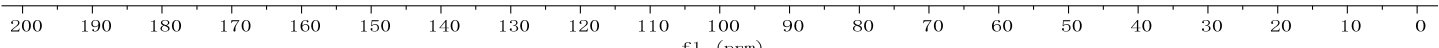




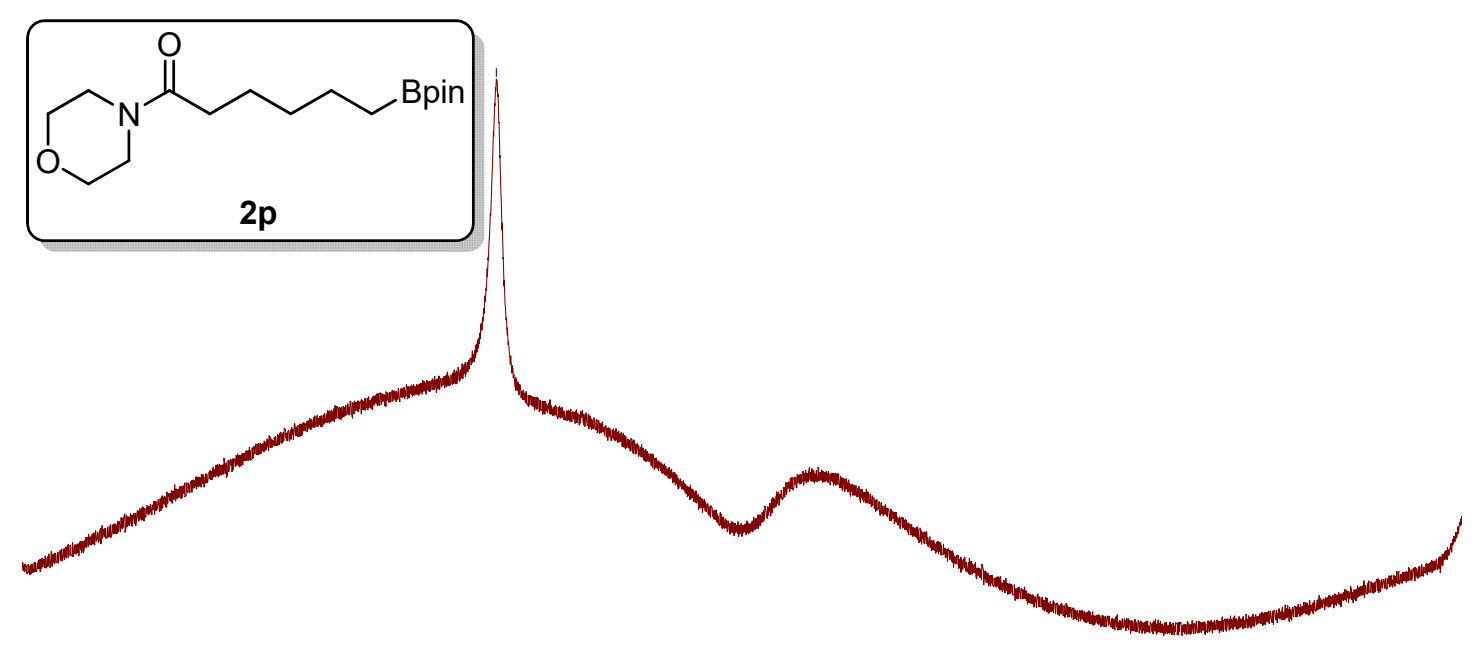

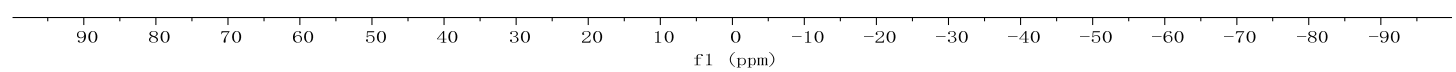



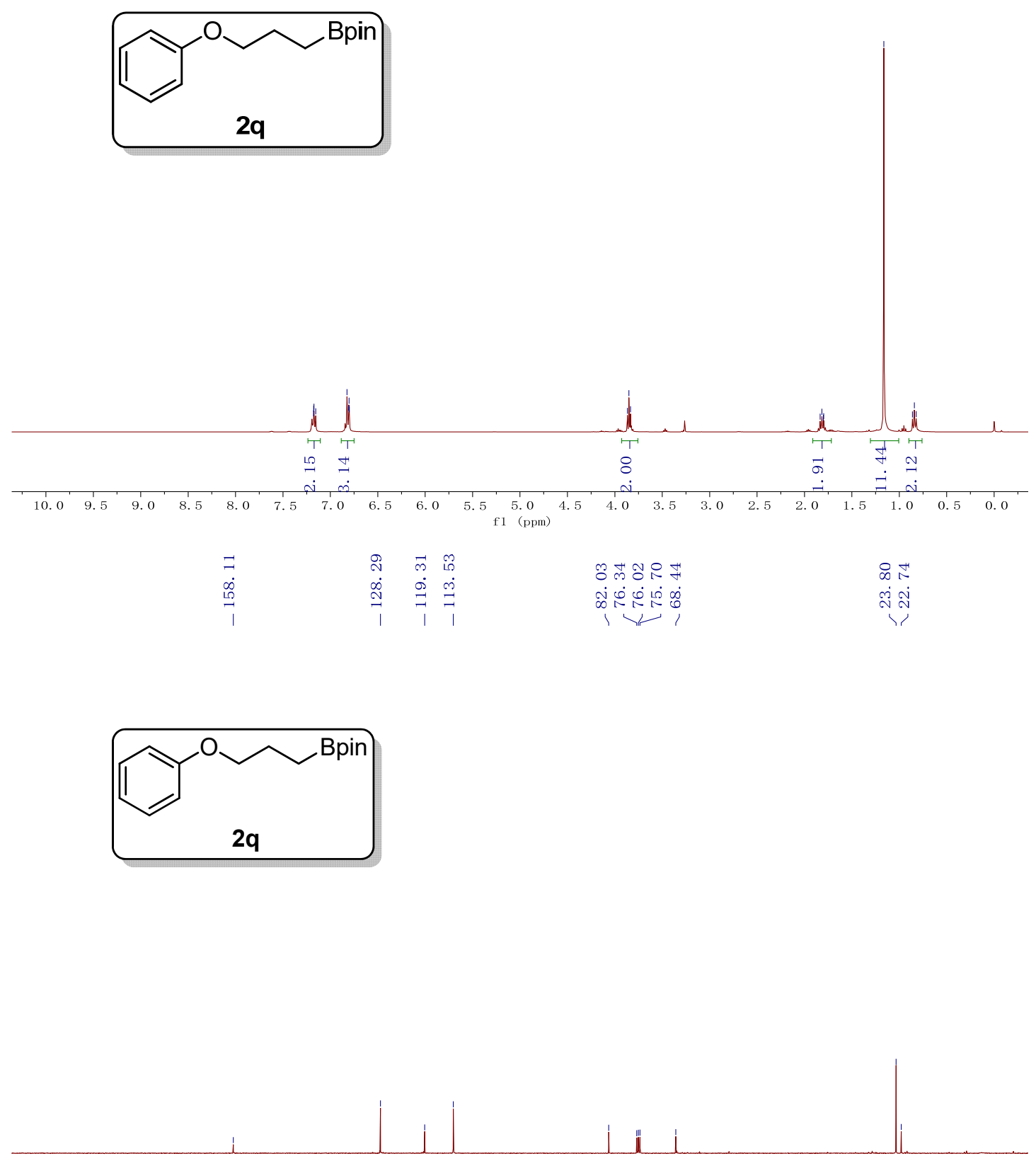

200 19
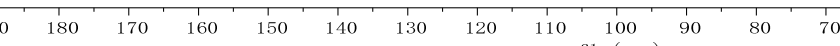

$\begin{array}{llllll}10 & 1 & 1 & 10 & 1\end{array}$ 


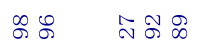

$\sim N \quad \therefore 0$

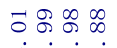

मं लं

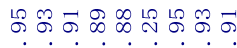

-
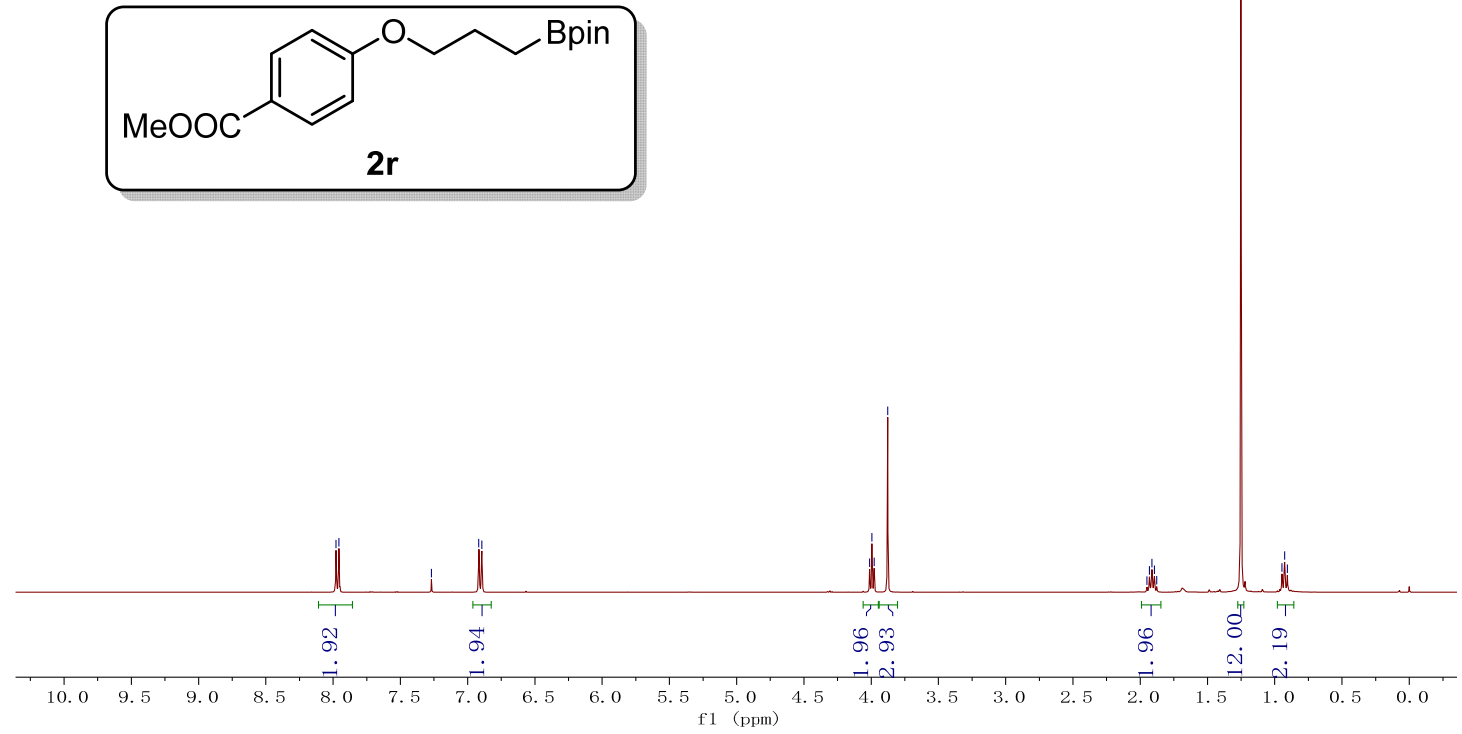

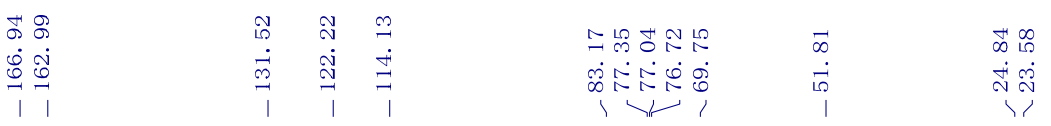
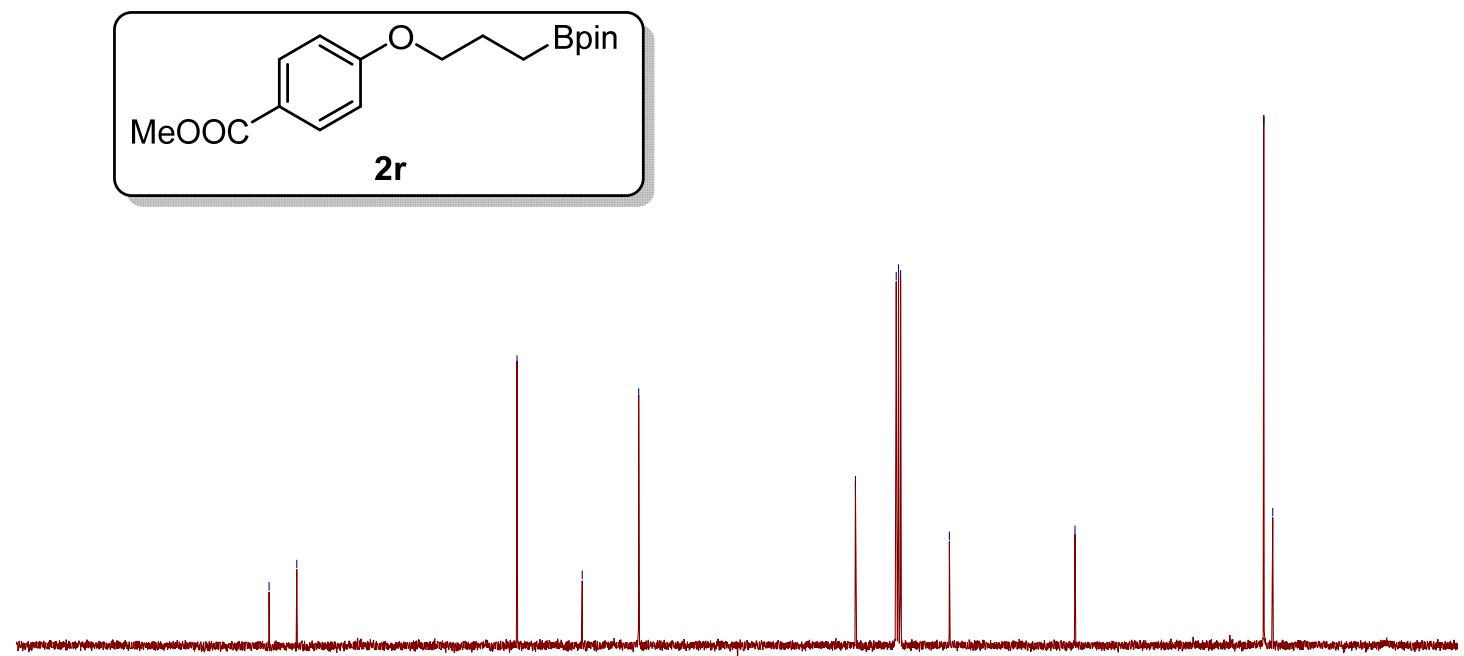

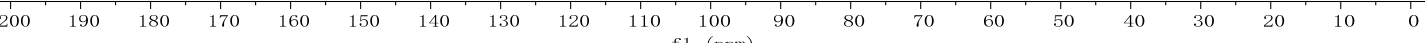



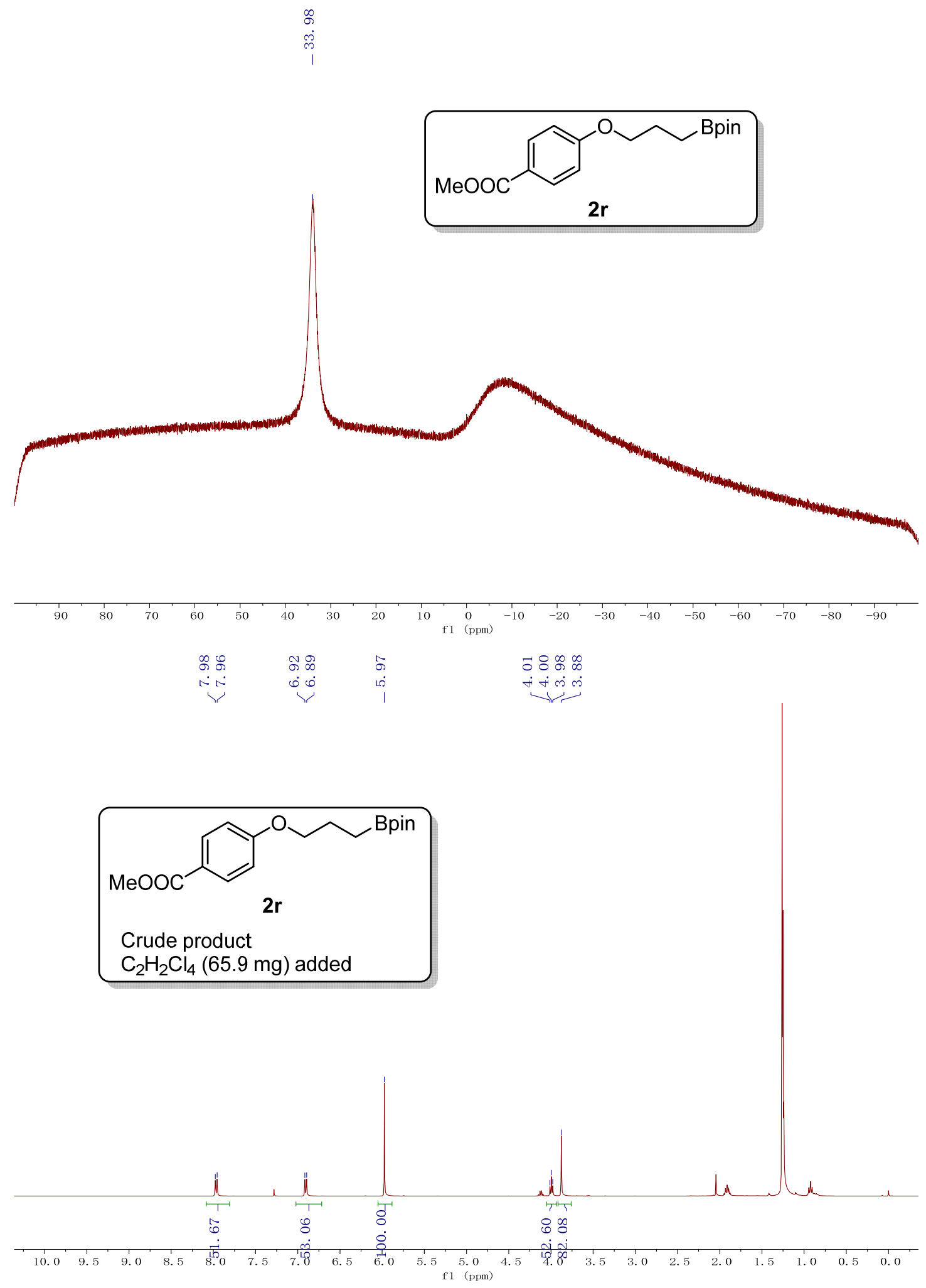


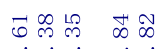

NNN
๙ै ఠ

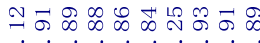

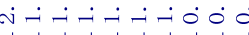
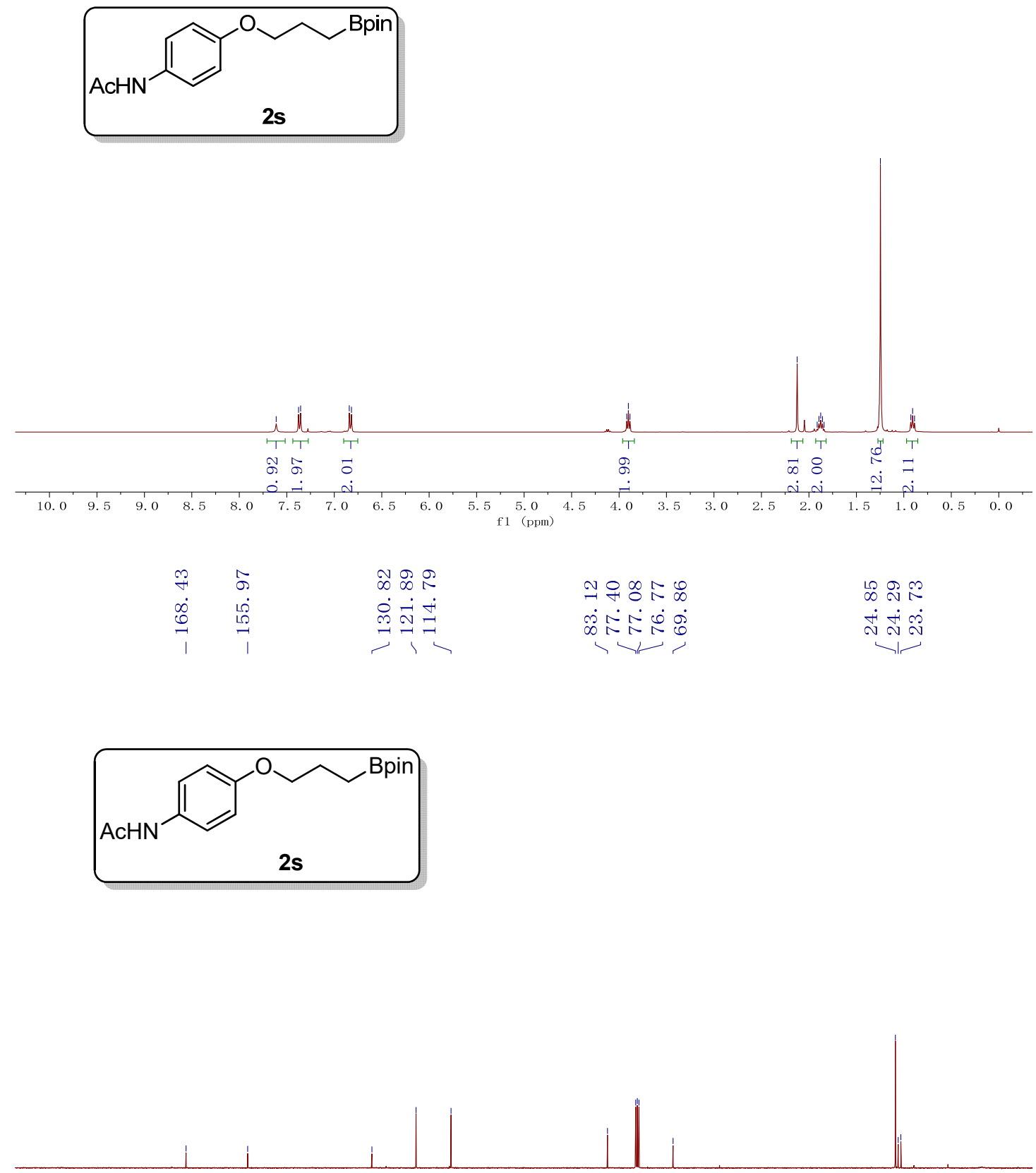

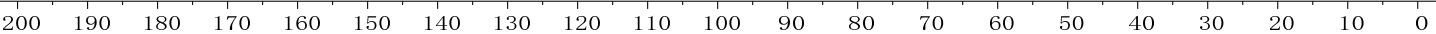




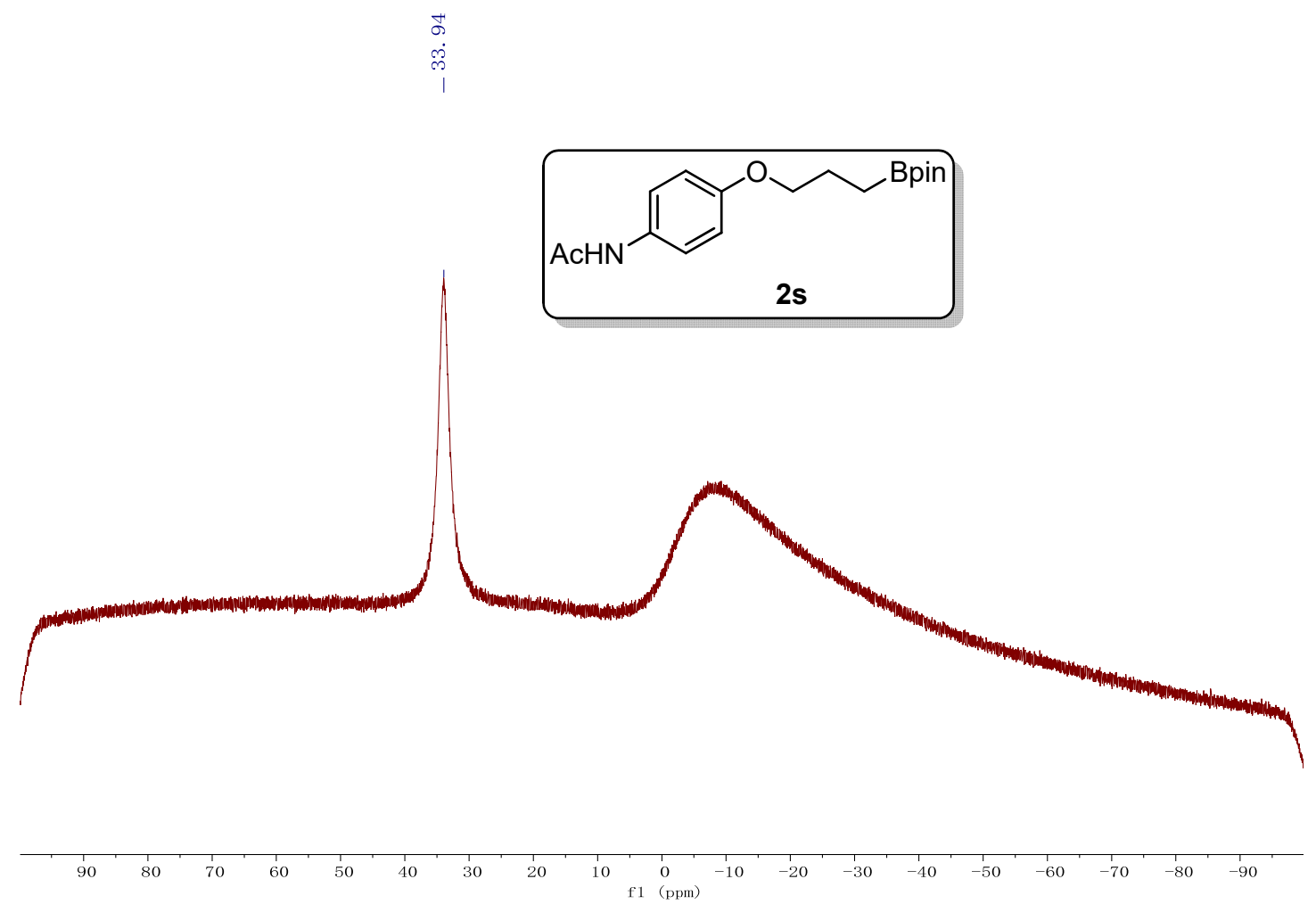



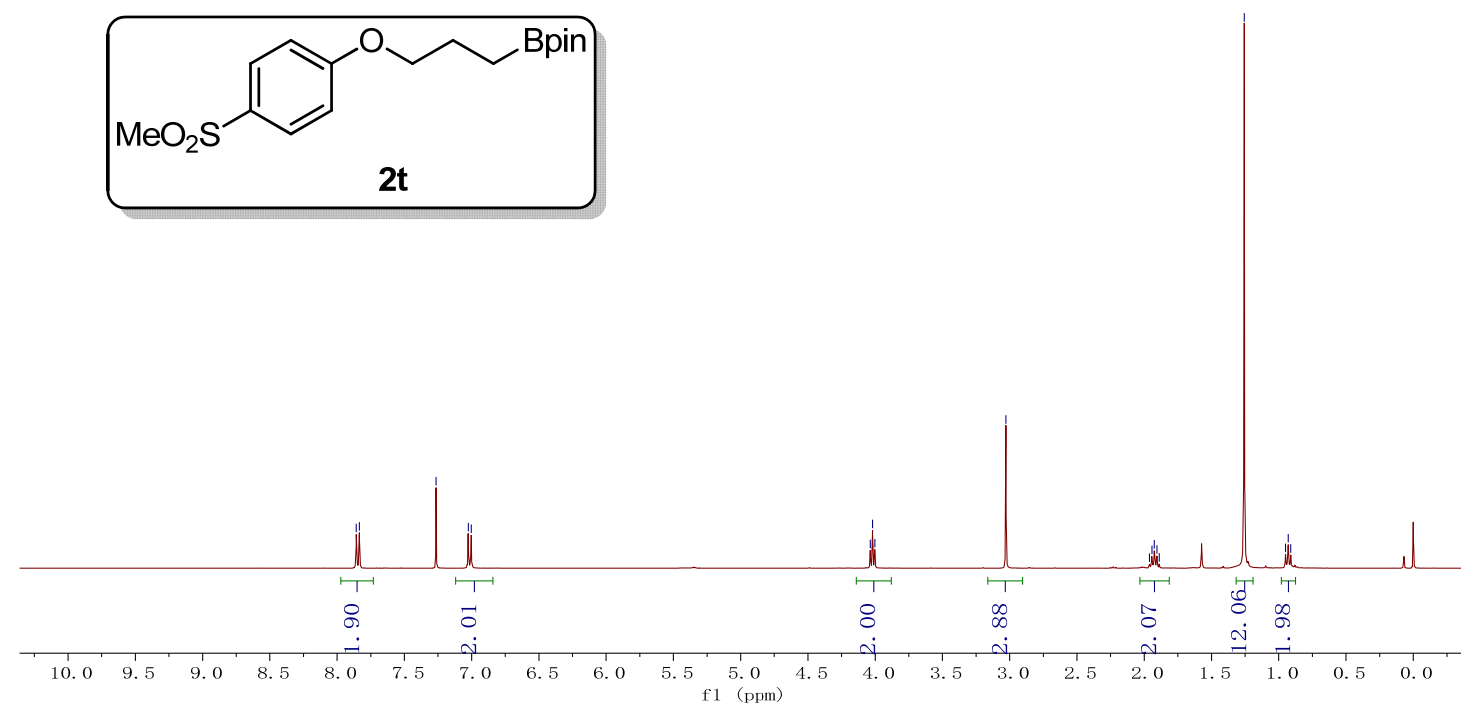

\begin{tabular}{|c|c|c|c|c|}
\hline $\begin{array}{l}\ddot{m} \\
m \\
\stackrel{0}{0}\end{array}$ & 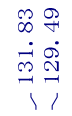 & $\begin{array}{l}\infty \\
o \\
\dot{+} \\
\exists \\
\end{array}$ & 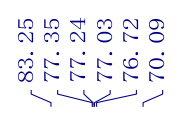 & $\begin{array}{l}\vec{\sigma} \\
\dot{+} \\
\dot{+}\end{array}$ \\
\hline
\end{tabular}

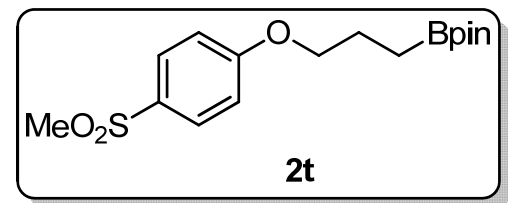

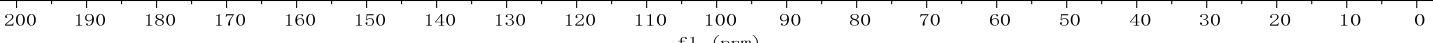




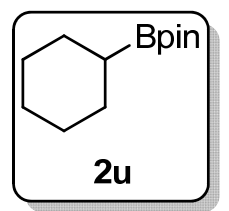

dul

ก

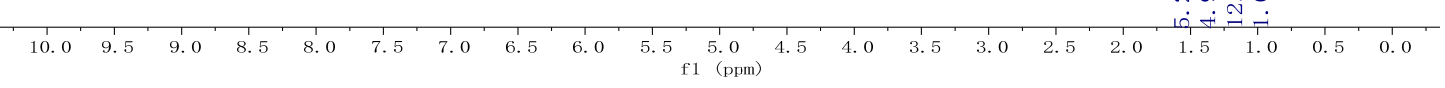

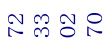

息艺是只

㐫卡

ลั

4

ir
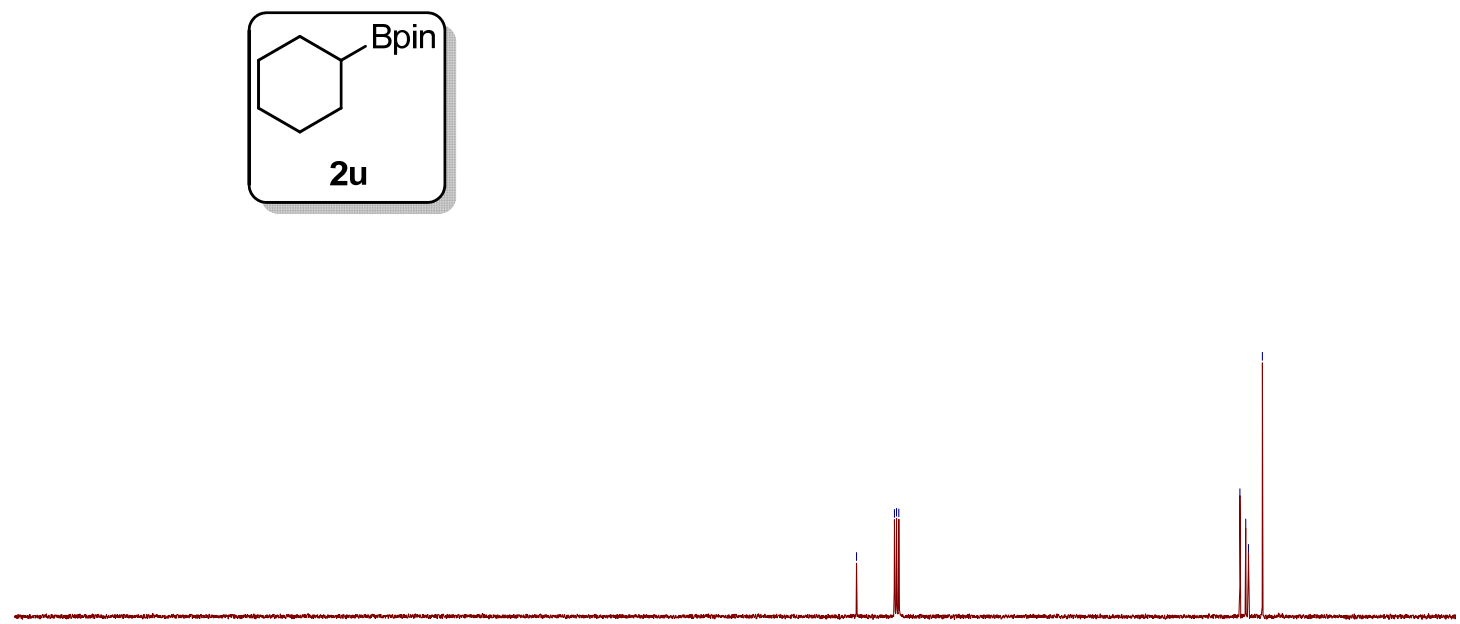

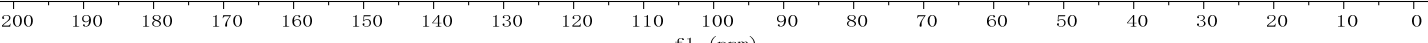



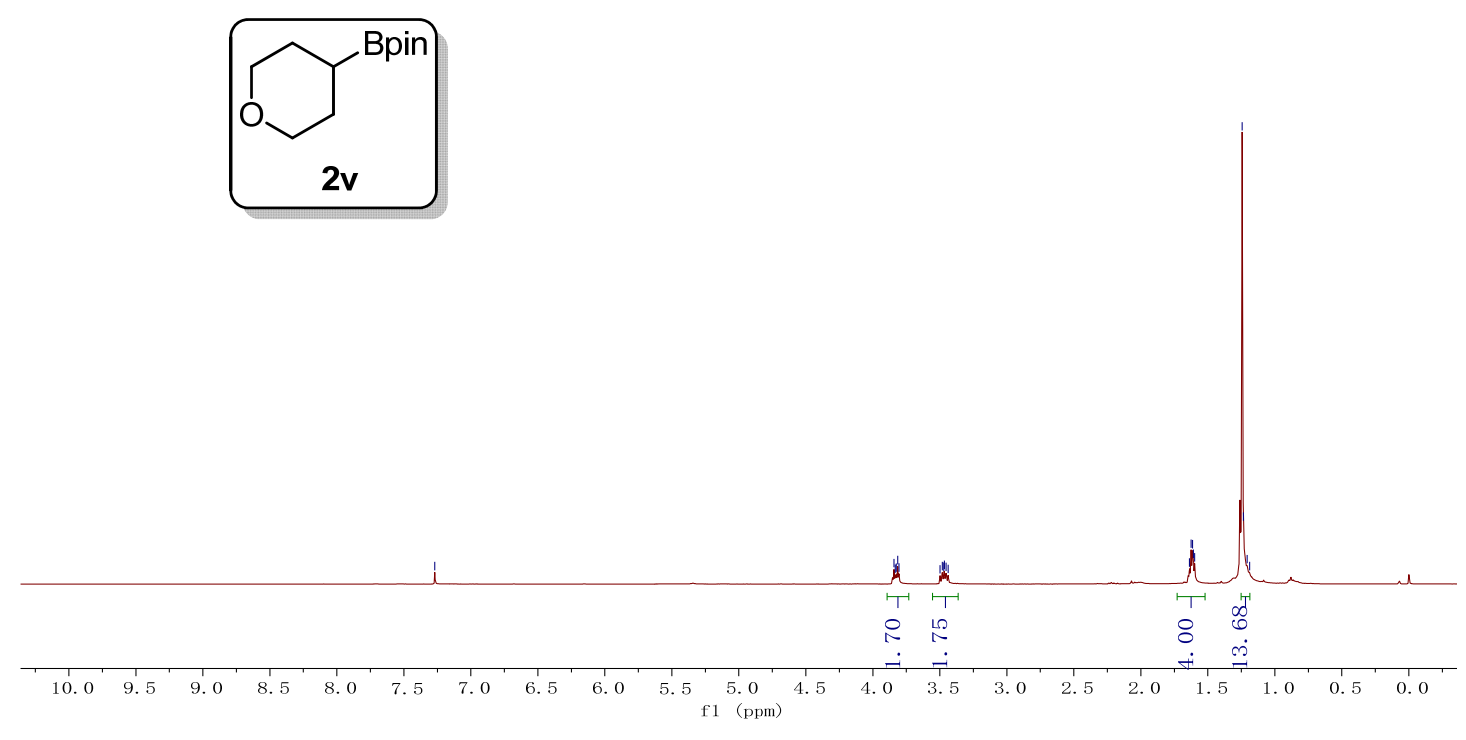

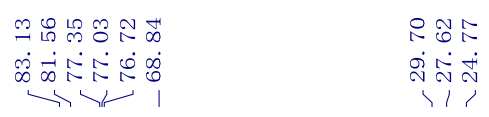
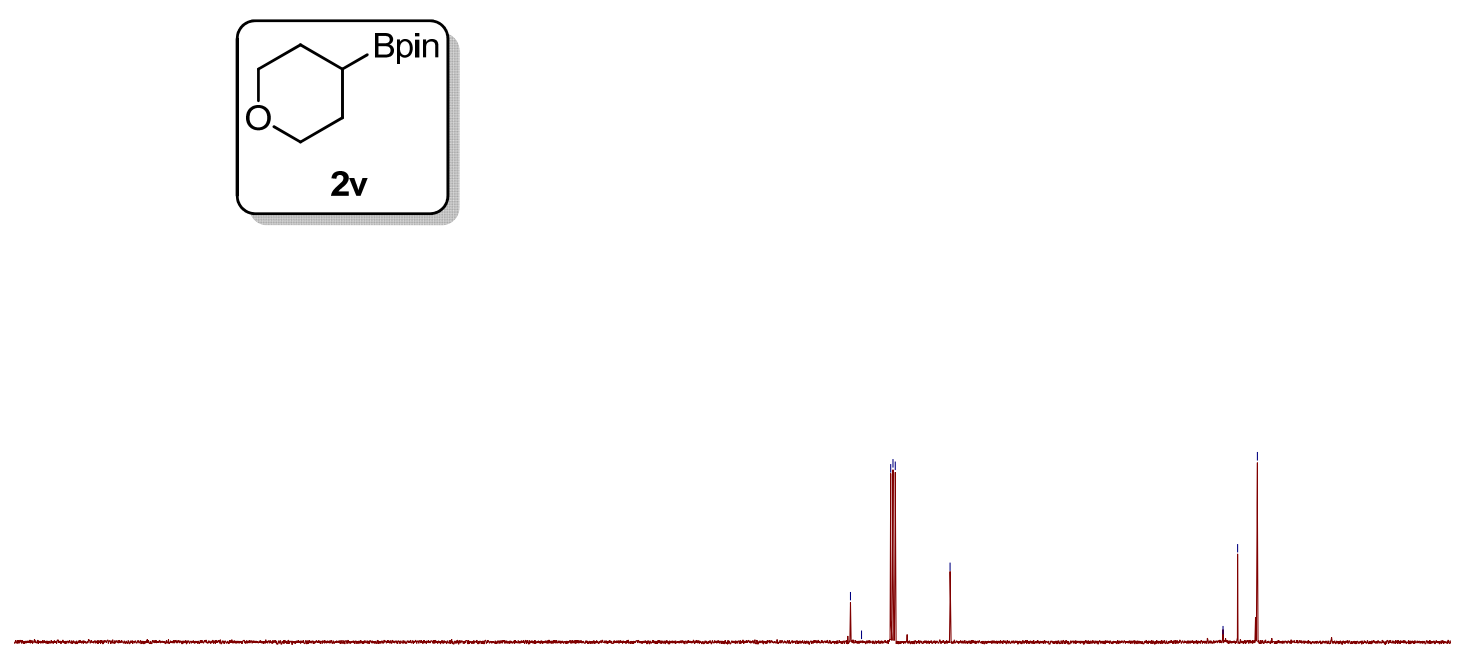

$\begin{array}{lllllllllllllllllllll}1 & 1 & 1 & 1 & 1 & 1 & 1 & 1 & 1 & 1 & 1 & 1 & 1 & 1 & 1 & 1 & 1 & 1 & 1 & 1 & 1 \\ 200 & 190 & 180 & 170 & 160 & 150 & 140 & 130 & 120 & 110 & 100 & 90 & 80 & 70 & 60 & 50 & 40 & 30 & 20 & 10 & 0\end{array}$ 

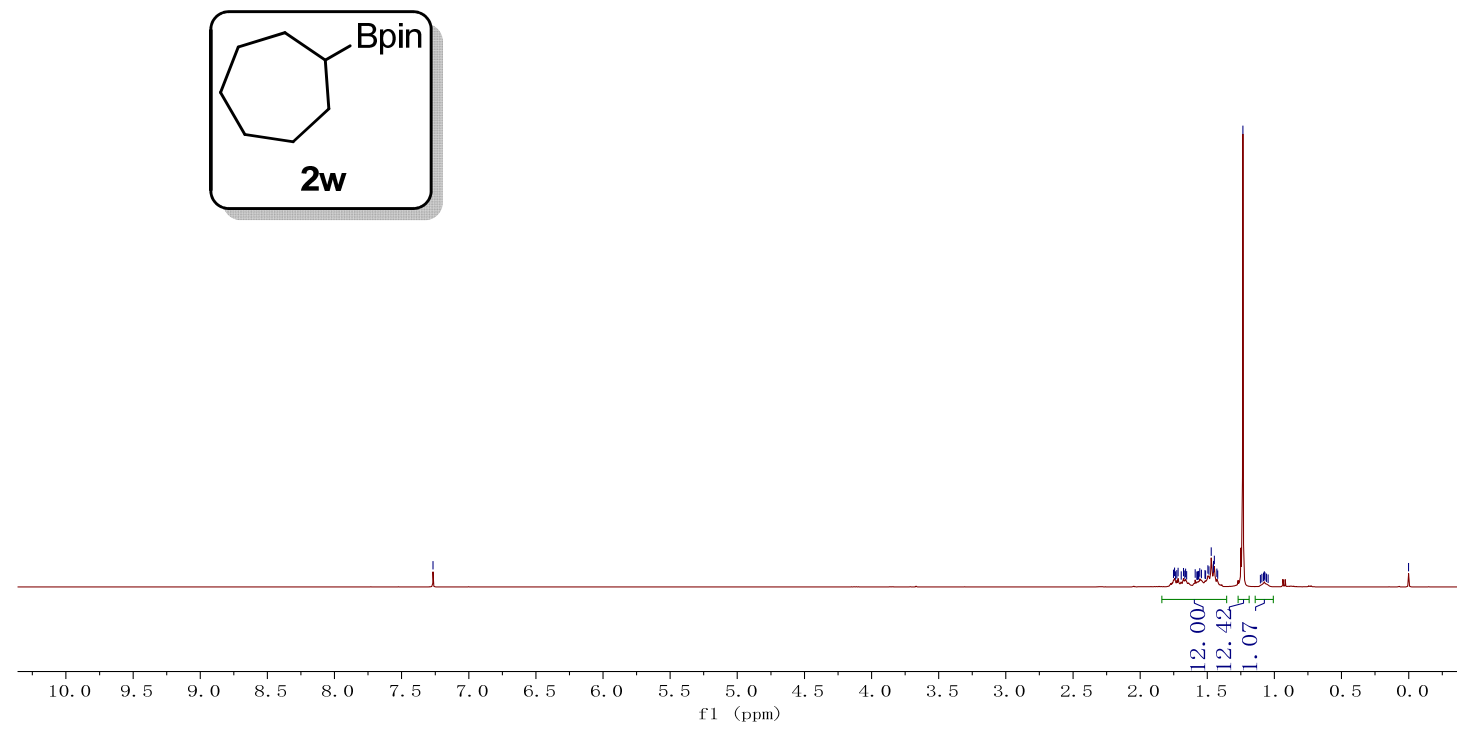

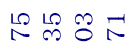

車忩完

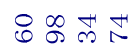

-

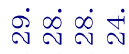

$\longrightarrow$
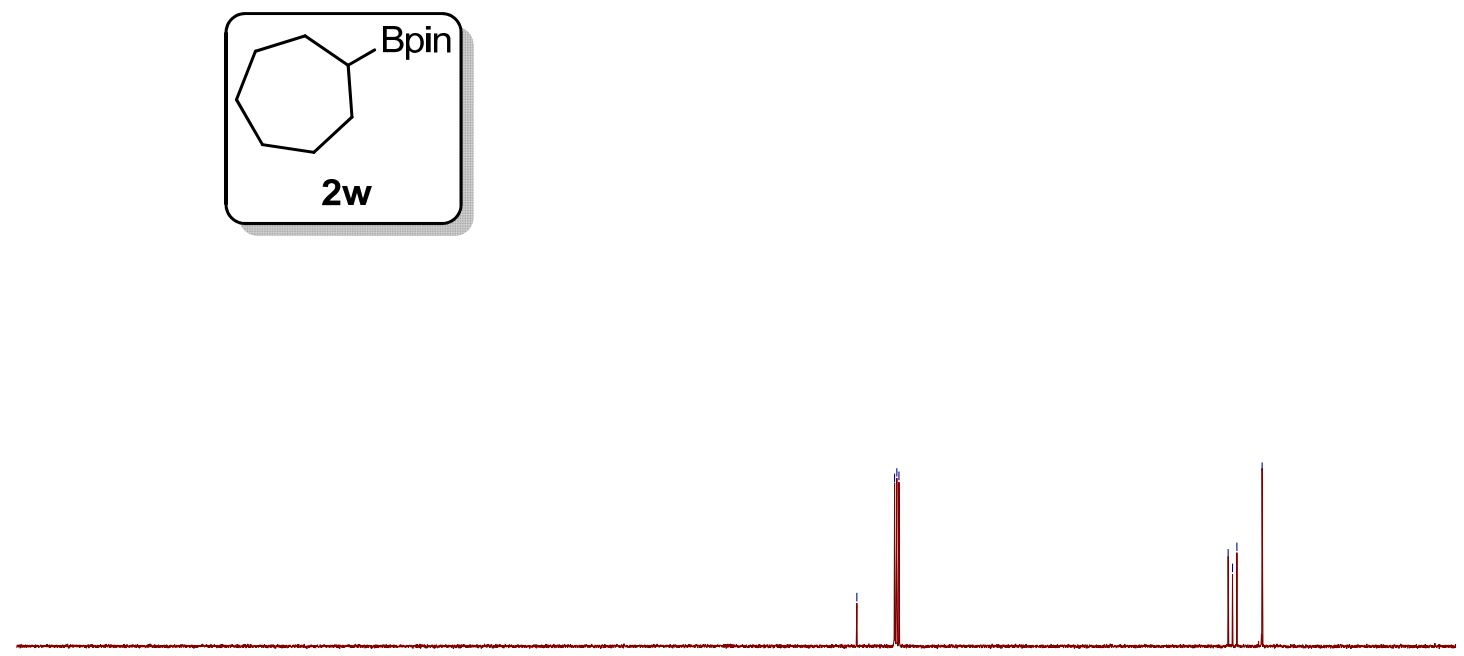

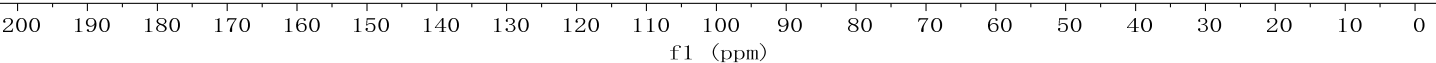




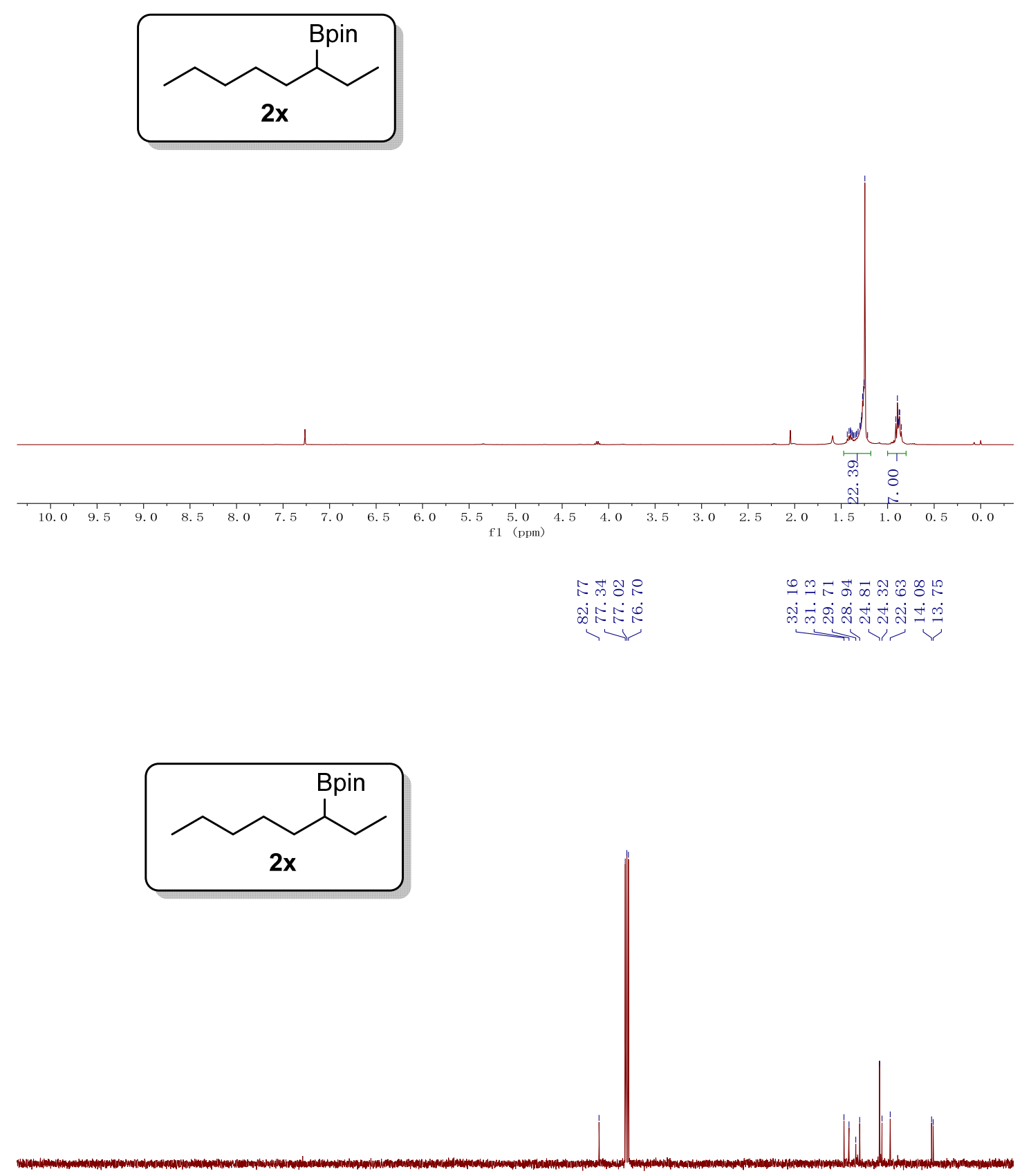

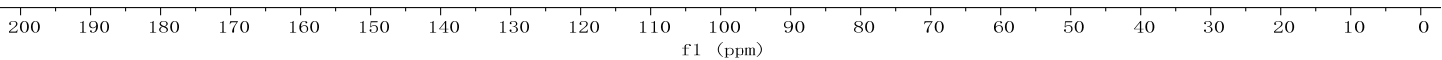




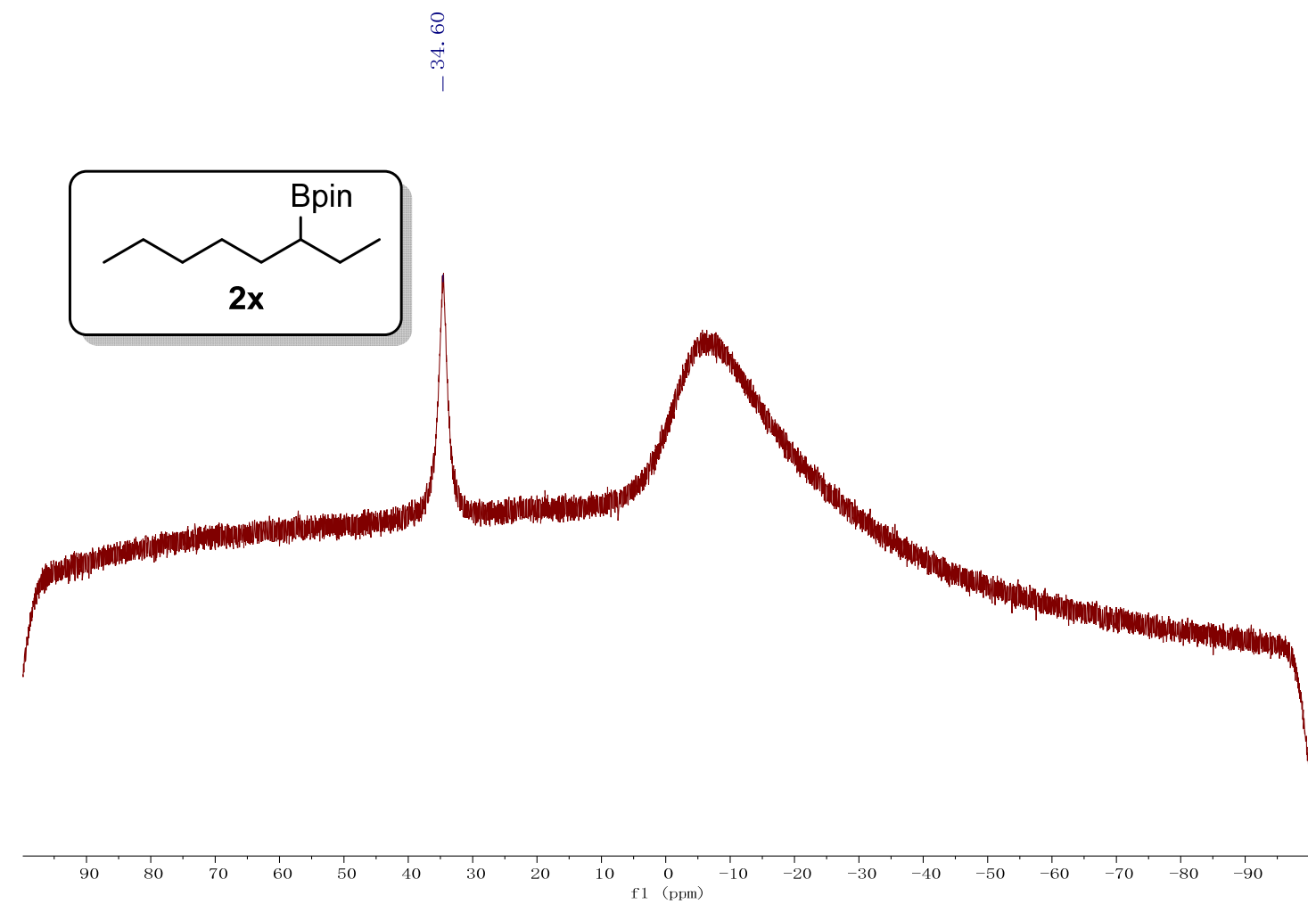



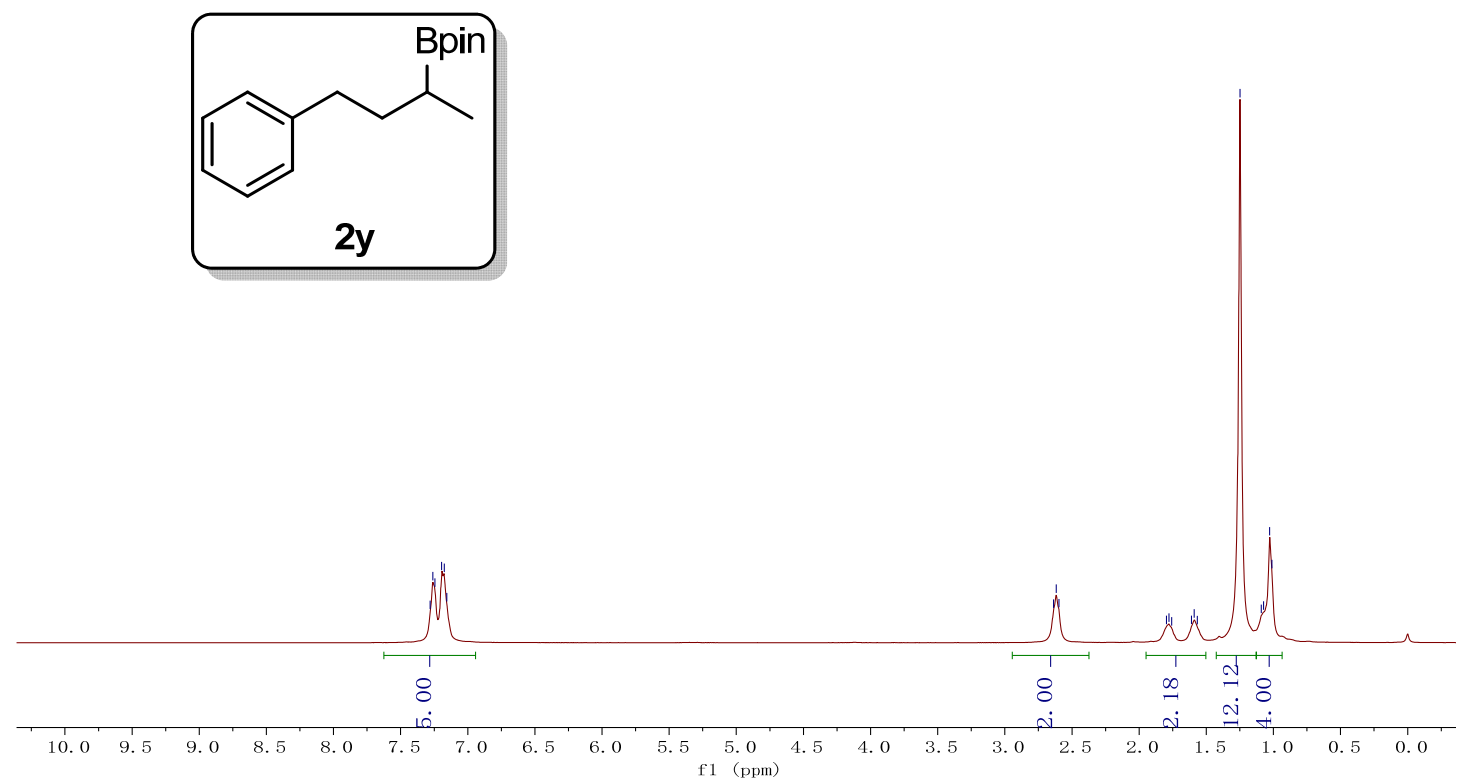

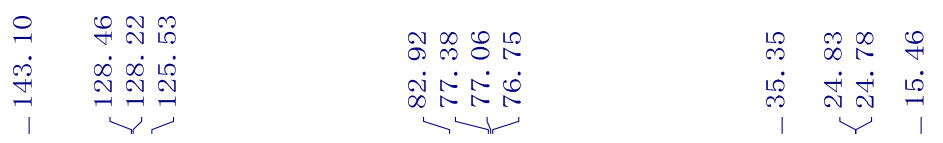
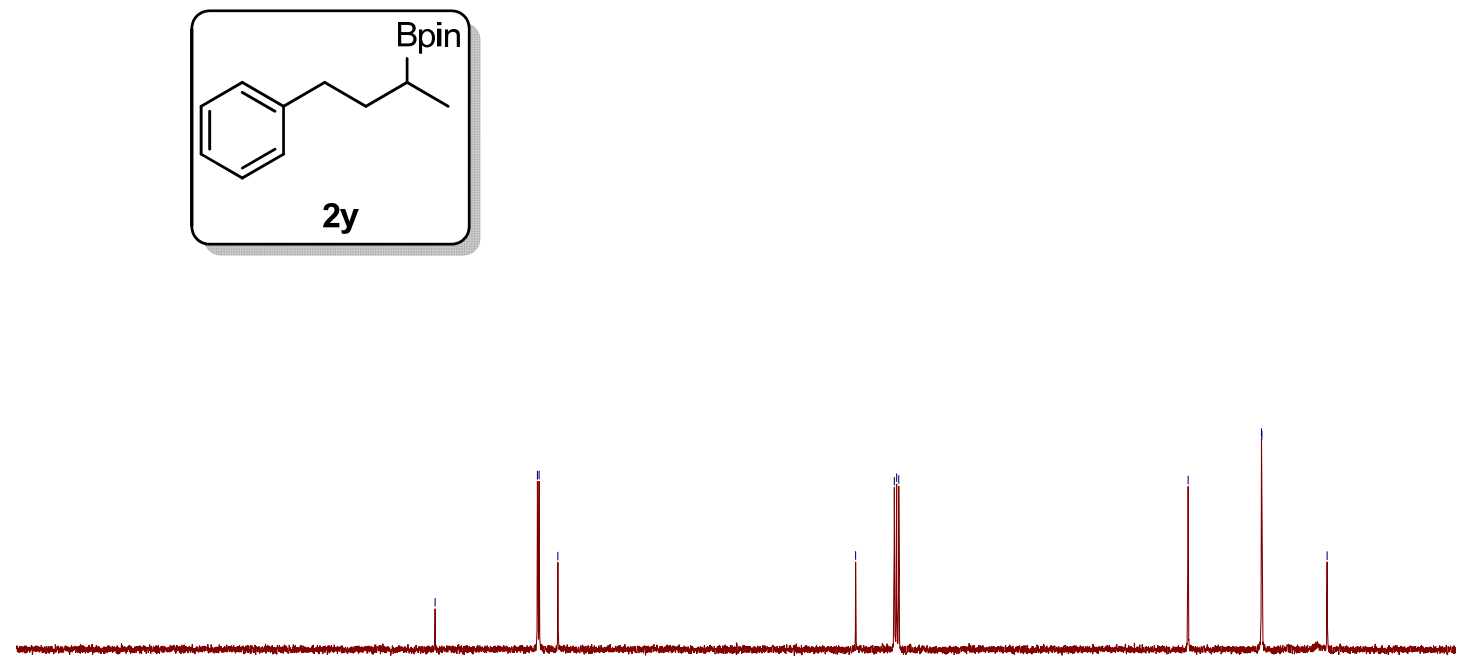

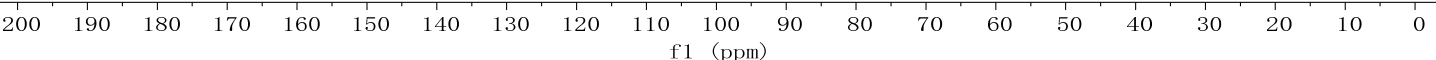




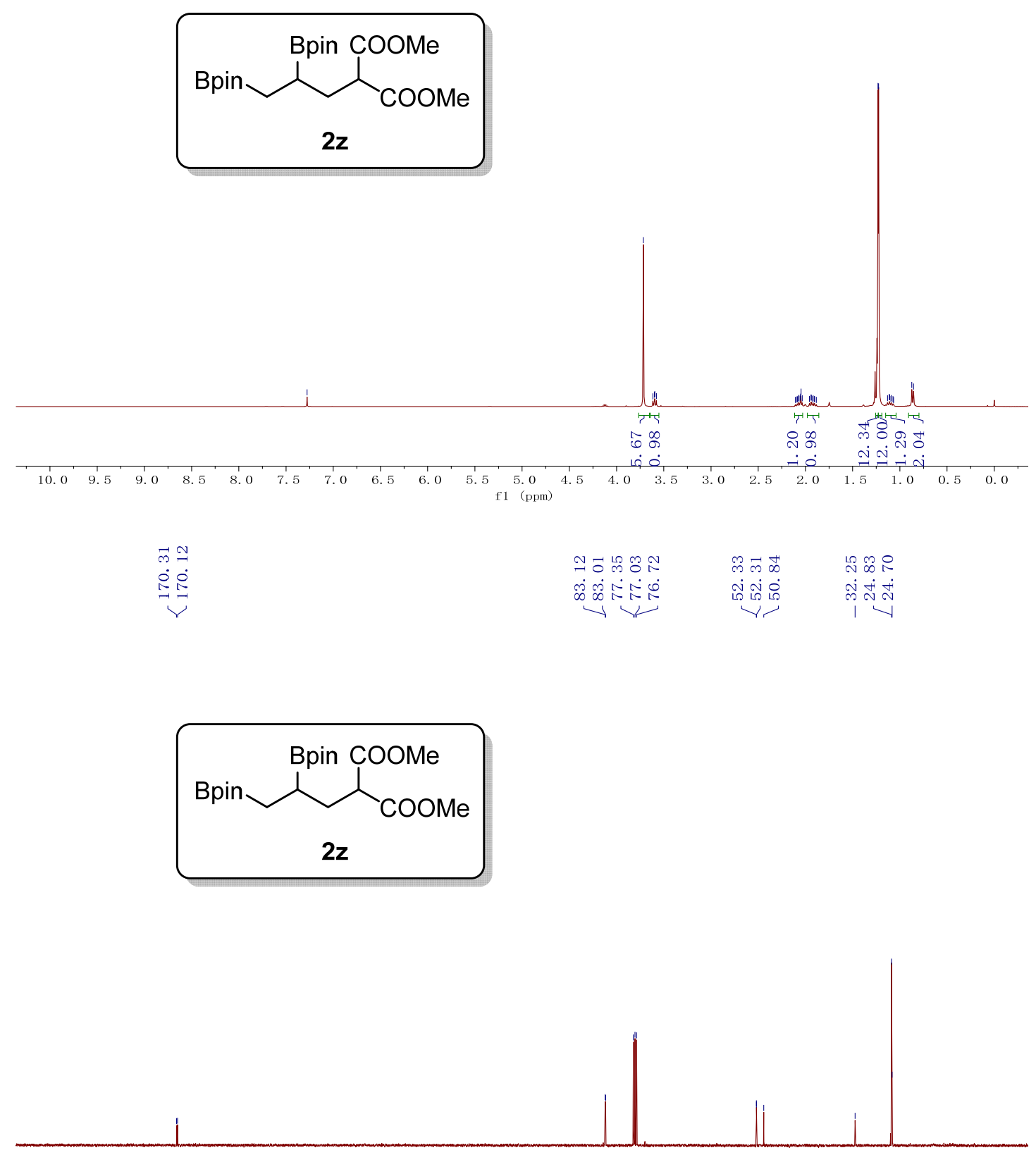

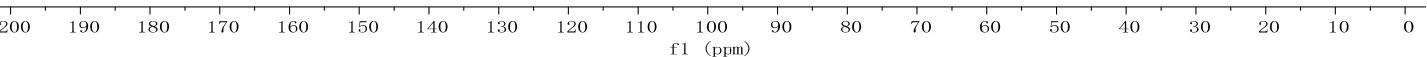




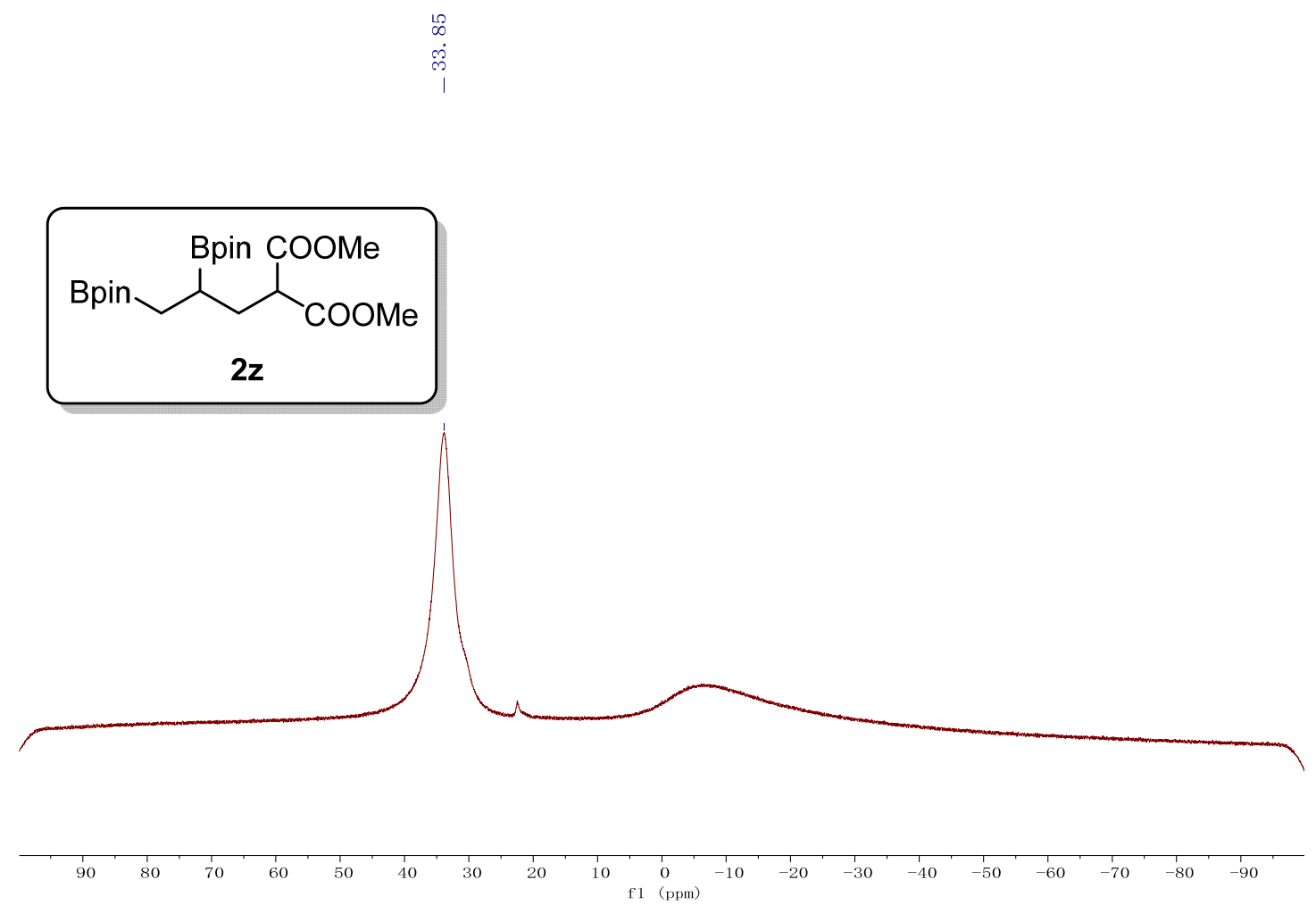




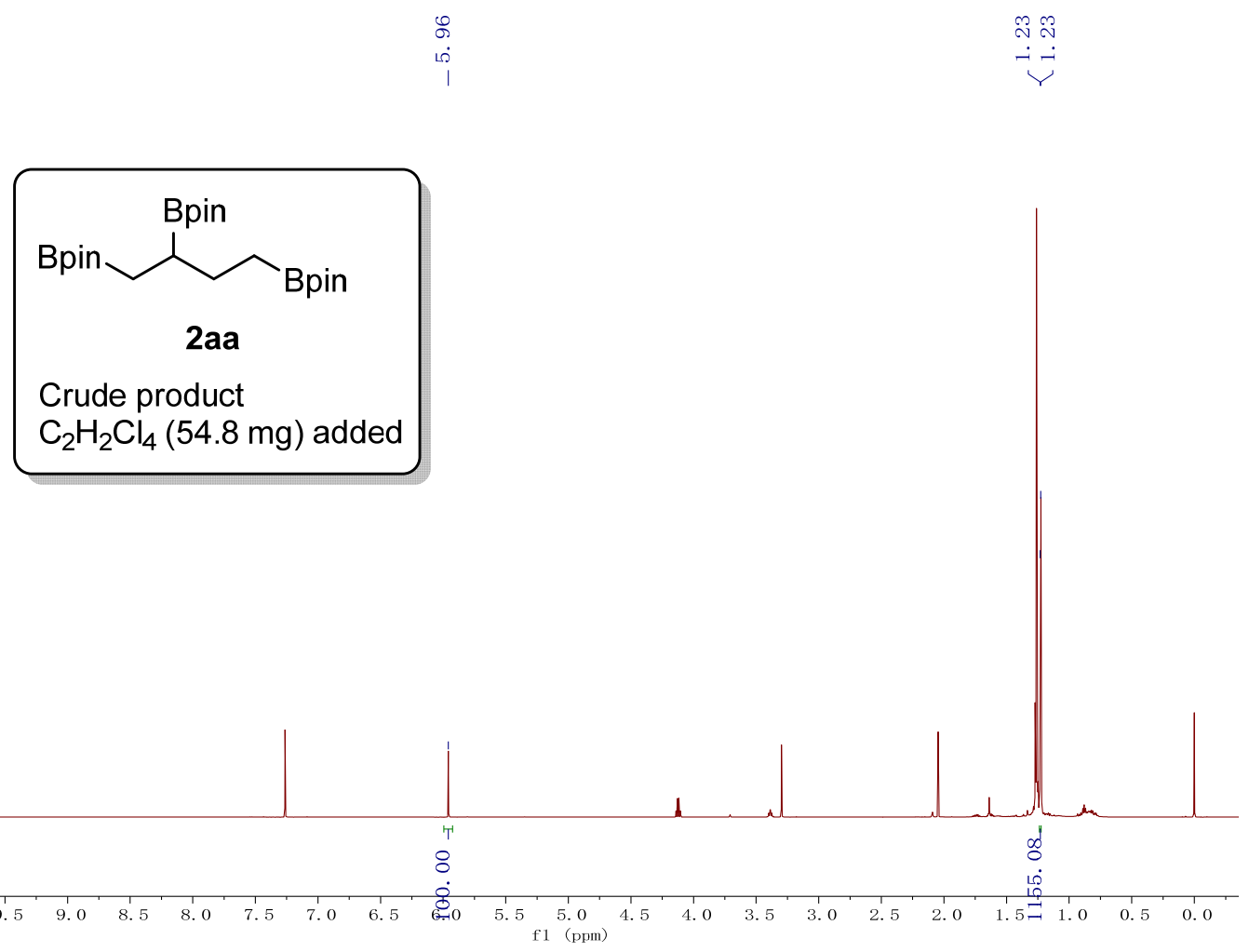




\section{Reference}

1. Du, S.; Kimball, E. A.; Ragains, J. R., Visible-Light-Promoted Remote C-H Functionalization of o-Diazoniaphenyl Alkyl Sulfones. Org. Lett. 2017, 19 (20), 5553-5556.

2. Kulbitski, K.; Nisnevich, G.; Gandelman, M., Metal-Free Efficient, General and Facile lododecarboxylation Method with Biodegradable Co-Products. Adv. Synth. Catal. 2011, 353 (9), 1438-1442.

3. Moriya, T.; Yoneda, S.; Kawana, K.; Ikeda, R.; Konakahara, T.; Sakai, N., Indium(III)-Catalyzed Reductive Bromination and lodination of Carboxylic Acids to Alkyl Bromides and lodides: Scope, Mechanism, and One-Pot Transformation to Alkyl Halides and Amine Derivatives. J. Org. Chem. 2013, 78 (21), 10642-10650.

4. Guziec, F. S.; Wei, D., Convenient halodeamination and hydrodeamination of primary amines. J. Org. Chem. 1992, 57 (14), 3772-3776.

5. Irifune, S.; Kibayashi, T.; Ishii, Y.; Ogawa, M., A Facile Synthesis of Alkyl lodides and Deuterated Alkyl lodides by Hydroiodination and Deuterioiodination of Olefins. Synthesis 1988, 5 (05), 366-369.

6. Artaryan, A.; Mardyukov, A.; Kulbitski, K.; Avigdori, I.; Nisnevich, G. A.; Schreiner, P. R.; Gandelman, M., Aliphatic $\mathrm{C}-\mathrm{H}$ Bond lodination by a N-lodoamide and Isolation of an Elusive N-Amidyl Radical. J. Org. Chem. 2017, 82 (14), 7093-7100.

7. Guisán-Ceinos, M.; Soler-Yanes, R.; Collado-Sanz, D.; Phapale, V. B.; Buñuel, E.; Cárdenas, D. J., $\mathrm{Ni}$ - Catalyzed Cascade Cyclization - Kumada Alkyl - Alkyl Cross - Coupling. Chem. Eur. J. 2013, 19 (26), 8405-8410.

8. Zhu, J.; Pérez, M.; Caputo, C. B.; Stephan, D. W., Use of Trifluoromethyl Groups for Catalytic Benzylation and Alkylation with Subsequent Hydrodefluorination. Angew. Chem. Int. Ed. 2016, 55 (4), 1417-1421.

9. Rokhum, L.; Das, D.; Chanda, T., Application of "Click" chemistry in solid phase synthesis of alkyl halides. Acta Chimica Slovenica; Vol 62, No 4 (2015) 2015.

10. Wang, X.; Ji, X.; Shao, C.; Zhang, Y.; Zhang, Y., Palladium-catalyzed C-H alkylation of 2-phenylpyridines with alkyl iodides Org. Biomol. Chem. 2017, 15 (26), 5616-5624.

11. Chen, J.; Lin, J.-H.; Xiao, J.-C., Halogenation through Deoxygenation of Alcohols and Aldehydes. Org. Lett. 2018, 20 (10), 3061-3064.

12. Biswas, S.; Weix, D. J., Mechanism and Selectivity in Nickel-Catalyzed Cross-Electrophile Coupling of Aryl Halides with Alkyl Halides. J. Am. Chem. Soc. 2013, 135 (43), 16192-16197.

13. Motoyama, Y.; Aoki, M.; Takaoka, N.; Aoto, R.; Nagashima, H., Highly efficient synthesis of aldenamines from carboxamides by iridium-catalyzed silane-reduction/dehydration under mild conditions. Chem. Commun. 2009, (12), 1574-1576.

14. Rampa, A.; Piazzi, L.; Belluti, F.; Gobbi, S.; Bisi, A.; Bartolini, M.; Andrisano, V.; Cavrini, V.; Cavalli, A.; Recanatini, M.; Valenti, P., Acetylcholinesterase Inhibitors: SAR and Kinetic Studies on w-[N-Methyl-N-(3-alkylcarbamoyloxyphenyl)methyl]aminoalkoxyaryl Derivatives. J. Med. Chem. 2001, 44 (23), 3810-3820.

15. Damont, A.; Médran-Navarrete, V.; Cacheux, F.; Kuhnast, B.; Pottier, G.; Bernards, N.; Marguet, F.; Puech, F.; Boisgard, R.; Dollé, F., Novel Pyrazolo[1,5-a]pyrimidines as Translocator Protein 18 kDa (TSPO) Ligands: Synthesis, in Vitro Biological Evaluation, [18F]-Labeling, and in Vivo Neuroinflammation PET Images. J. Med. Chem. 2015, 58 (18), 7449-7464.

16. Kitagawa, O.; Yamada, Y.; Sugawara, A.; Taguchi, T., Radical Cascade Reaction with 1,4-Dienes 
and 1,4-Enynes Using 2-(lodomethyl)cyclopropane-1,1-dicarboxylate as a Homoallyl Radical Precursor: One-Step Synthesis of Bicyclo[3.3.0]octane Derivatives. Org. Lett. 2002, 4 (6), 1011-1013.

17. Gu, X.; Li, X.; Qu, Y.; Yang, Q.; Li, P.; Yao, Y., Intermolecular Visible-Light Photoredox Atom-Transfer Radical [3+2]-Cyclization of 2-(lodomethyl)cyclopropane-1,1-dicarboxylate with Alkenes and Alkynes. Chem. Eur. J. 2013, 19 (36), 11878-11882.

18. Cheng, Y.; Mück-Lichtenfeld, C.; Studer, A., Metal-Free Radical Borylation of Alkyl and Aryl lodides. Angew. Chem. Int. Ed. 2018, 57 (51), 16832-16836.

19. Glasspoole, B. W.; Ghozati, K.; Moir, J. W.; Crudden, C. M., Suzuki-Miyaura cross-couplings of secondary allylic boronic esters. Chem. Commun. 2012, 48 (9), 1230-1232.

20. Tamang, S. R.; Bedi, D.; Shafiei-Haghighi, S.; Smith, C. R.; Crawford, C.; Findlater, M., Cobalt-Catalyzed Hydroboration of Alkenes, Aldehydes, and Ketones. Org. Lett. 2018, 20 (21), 6695-6700.

21. Zhang, L.; Zuo, Z.; Leng, X.; Huang, Z., A Cobalt-Catalyzed Alkene Hydroboration with Pinacolborane. Angew. Chem. Int. Ed. 2014, 53 (10), 2696-2700.

22. Wu, J.; He, L.; Noble, A.; Aggarwal, V. K., Photoinduced Deaminative Borylation of Alkylamines. J. Am. Chem. Soc. 2018, 140 (34), 10700-10704.

23. Noble, A.; Mega, R. S.; Pflästerer, D.; Myers, E. L.; Aggarwal, V. K., Visible-Light-Mediated Decarboxylative Radical Additions to Vinyl Boronic Esters: Rapid Access to $\gamma$-Amino Boronic Esters. Angew. Chem. Int. Ed. 2018, 57 (8), 2155-2159.

24. Everson, D. A.; Jones, B. A.; Weix, D. J., Replacing Conventional Carbon Nucleophiles with Electrophiles: Nickel-Catalyzed Reductive Alkylation of Aryl Bromides and Chlorides. J. Am. Chem. Soc. 2012, 134 (14), 6146-6159.

25. Hu, J.; Wang, G.; Li, S.; Shi, Z., Selective C-N Borylation of Alkyl Amines Promoted by Lewis Base. Angew. Chem. Int. Ed. 2018, 57 (46), 15227-15231.

26. Zhang, Y.; Jiang, H.; Chen, D.; Zhang, Y., Amino acid-promoted C-H alkylation with alkylboronic acids using a removable directing group. Org. Biomol. Chem. 2016, 14 (20), 4585-4589.

27. Yin, Q.; Kemper, S.; Klare, H. F. T.; Oestreich, M., Boron Lewis Acid-Catalyzed Hydroboration of Alkenes with Pinacolborane: BArF3 Does What B(C6F5)3 Cannot Do! Chem. Eur. J. 2016, 22 (39), 13840-13844.

28. Levin, V. V.; Zemtsov, A. A.; Struchkova, M. I.; Dilman, A. D., Reactions of Difluorocarbene with Organozinc Reagents. Org. Lett. 2013, 15 (4), 917-919.

29. Grenouillat, N.; Vauzeilles, B.; Bono, J.-J.; Samain, E.; Beau, J.-M., Simple Synthesis of Nodulation-Factor Analogues Exhibiting High Affinity towards a Specific Binding Protein. Angew. Chem. Int. Ed. 2004, 43 (35), 4644-4646.

30. Bose, S. K.; Fucke, K.; Liu, L.; Steel, P. G.; Marder, T. B., Zinc-Catalyzed Borylation of Primary, Secondary and Tertiary Alkyl Halides with Alkoxy Diboron Reagents at Room Temperature. Angew. Chem. Int. Ed. 2014, 53 (7), 1799-1803.

31. Ito, H.; Kubota, K., Copper(I)-Catalyzed Boryl Substitution of Unactivated Alkyl Halides. Org. Lett. 2012, 14 (3), 890-893.

32. Yang, C.-T.; Zhang, Z.-Q.; Tajuddin, H.; Wu, C.-C.; Liang, J.; Liu, J.-H.; Fu, Y.; Czyzewska, M.; Steel, P. G.; Marder, T. B.; Liu, L., Alkylboronic Esters from Copper-Catalyzed Borylation of Primary and Secondary Alkyl Halides and Pseudohalides. Angew. Chem. Int. Ed. 2012, 51 (2), 528-532.

33. Buettner, G. R., Spin Trapping: ESR parameters of spin adducts 1474 1528V. Free. Radical. Bio. Med 1987, 3 (4), 259-303. 
34. Janzen, E. G.; Liu, J. I. P., Radical addition reactions of 5,5-Dimethyl-1-pyrroline-1-oxide. ESR spin trapping with a cyclic nitrone. Journal of Magnetic Resonance (1969) 1973, 9 (3), 510-512.

35. Augusto, O.; Kunze, K. L.; Ortiz de Montellano, P. R., N-Phenylprotoporphyrin IX formation in the hemoglobin-phenylhydrazine reaction. Evidence for a protein-stabilized iron-phenyl intermediate. J. Biol. Chem. 1982, 257 (11), 6231-6241.

36. Hill, H. A. O.; Thornalley, P. J., Phenyl radical production during the oxidation of phenylhydrazine and in phenylphydrazine-induced haemolysis. Febs. Lett. 1981, 125 (2), 235-238.

37. Makino, K.; Mossoba, M. M.; Riesz, P., Chemical effects of ultrasound on aqueous solutions. Evidence for hydroxyl and hydrogen free radicals (.cntdot.OH and .cntdot.H) by spin trapping. J. Am. Chem. Soc. 1982, 104 (12), 3537-3539. 